University of Louisville

ThinkIR: The University of Louisville's Institutional Repository

Electronic Theses and Dissertations

1932

\title{
Sir Philip Sidney : Renaissance courtier and gentleman.
}

Mariam Sidebottom Houchens

University of Louisville

Follow this and additional works at: https://ir.library.louisville.edu/etd

Part of the European History Commons, and the Literature in English, British Isles Commons

\section{Recommended Citation}

Houchens, Mariam Sidebottom, "Sir Philip Sidney : Renaissance courtier and gentleman." (1932).

Electronic Theses and Dissertations. Paper 1970.

https://doi.org/10.18297/etd/1970

This Master's Thesis is brought to you for free and open access by ThinkIR: The University of Louisville's Institutional Repository. It has been accepted for inclusion in Electronic Theses and Dissertations by an authorized administrator of ThinkIR: The University of Louisville's Institutional Repository. This title appears here courtesy of the author, who has retained all other copyrights. For more information, please contact thinkir@louisville.edu. 


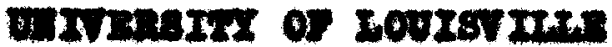

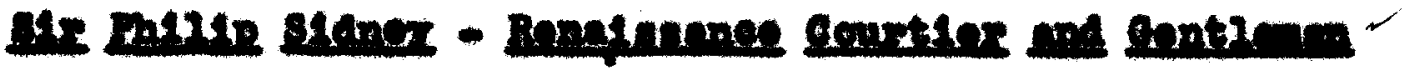

\author{
4 Biseortation \\ cruncttod to the Faculty

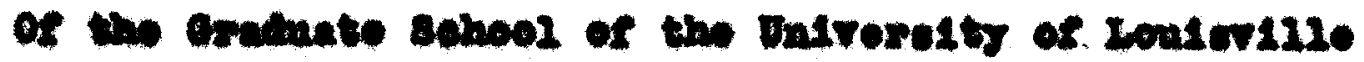 \\ In Portid ravelyumb of the \\ Dogul remente for the Dogros \\ or Inator of Arte
}

Dopartmont of Inglioh

$\mathbf{b}$

Ino1m slabooten Ieuchons $r$

Xow

1938 


\section{UHE UNWvessir LIBRARIES}

This PDF document is a scanned copy of a paper manuscript housed in the University of Louisville (UofL) Libraries. The quality of this reproduction is greatly dependent upon the condition of the original paper copy. Indistinct print and poor quality illustrations are a direct reflection of the quality of materials that are available for scanning. The UofL Libraries greatly appreciates any better copies that can be made available for replacement scans. 
2

o

$m$

$\checkmark$

3 $\infty$ \%

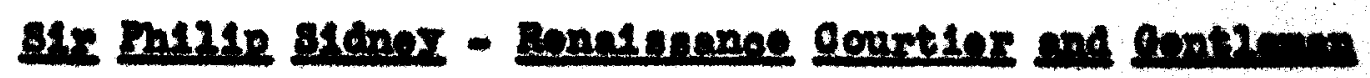

conrextres

Introtuotion

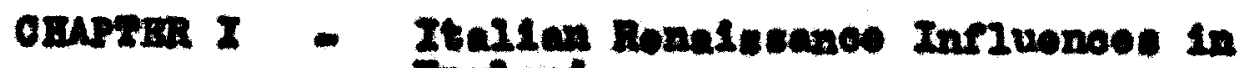
Englend

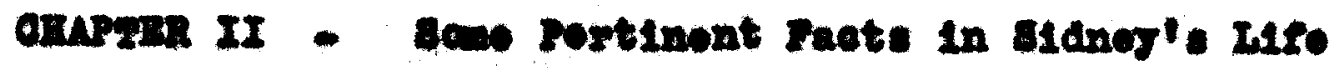

OLupran IIX - Bsonos, courties or Gentlement

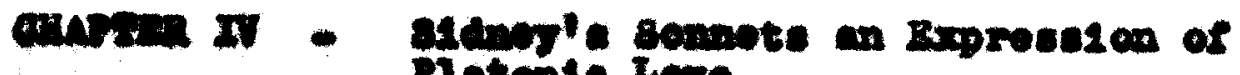
Ratemie Love

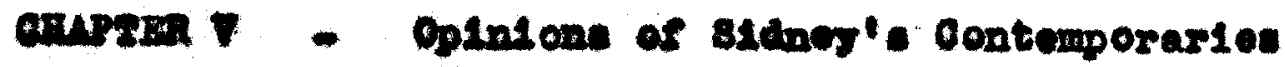

coneluezen

B201Lecrephy 
mtrodwotica

-

- 
moreduotien

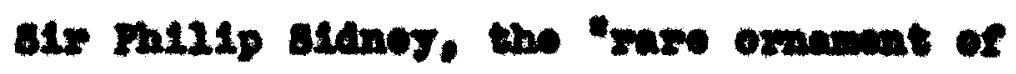
his age", the "nost aceomplinhed avaller of his

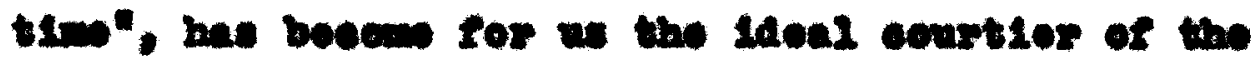
misubethen poried. It is as of the nost romeribable

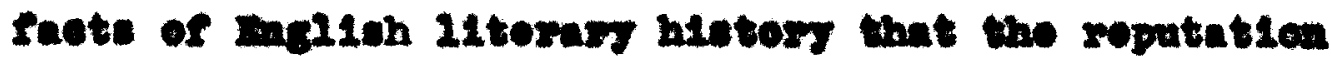

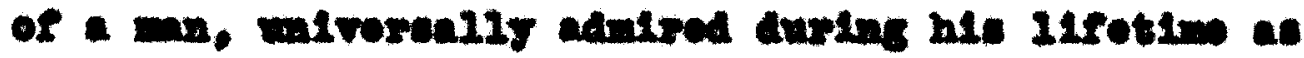
the slowe of oblvaly, has ouffored 21ttle or no dotration at the hands of throe and enombale coaturles.

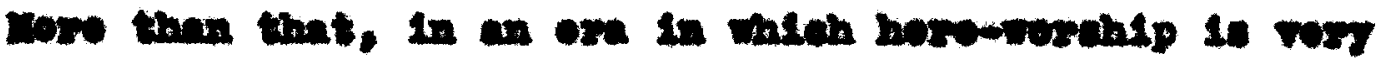

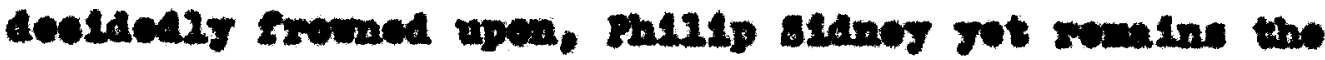

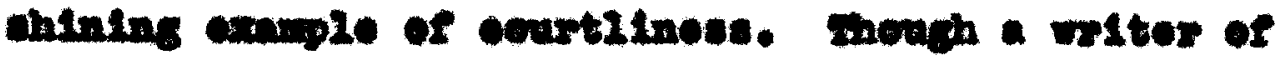
sem note. It it his chasacter, and not hie coalus, mich 19, and bas ower bese reasered. Eowever, these are ming problem in the any

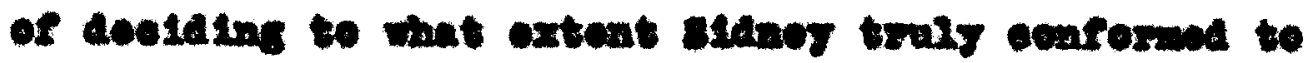
the ldoale of courtilnose. Cas of those would ourely

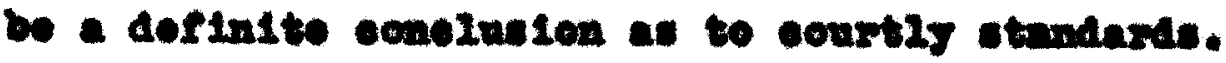
Anothos weuld certalmy be the ablilty to weo partleular

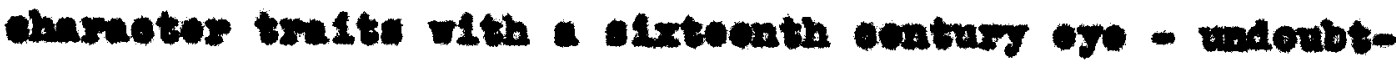

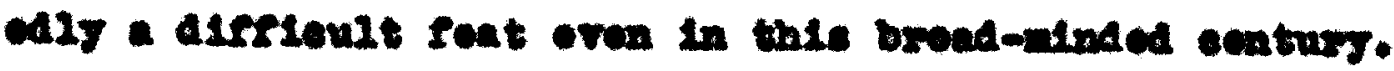




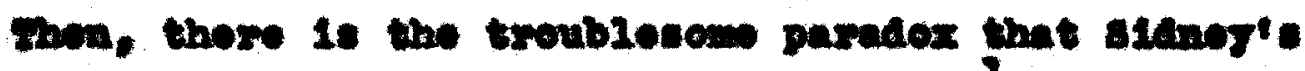

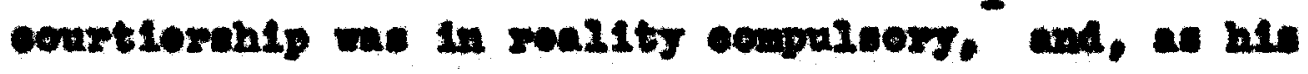
Ietters to Eanguot w111 prove, that ho was orter

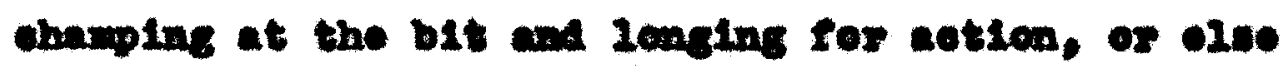

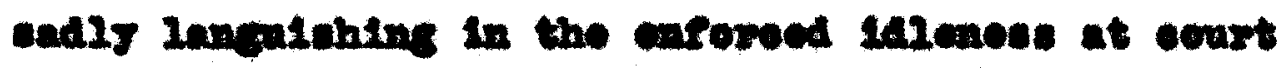

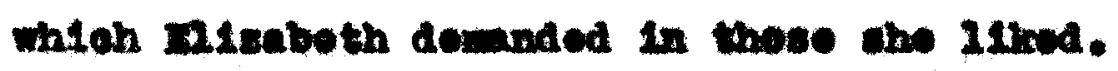

Two sondeacy of the provent dey socwe to bo

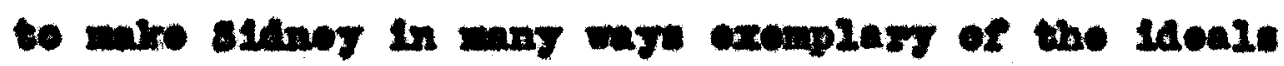
oot forth by Buldesare Gastiglone in his $1 \mathrm{I}$ gorter-

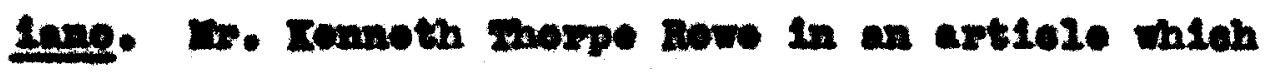

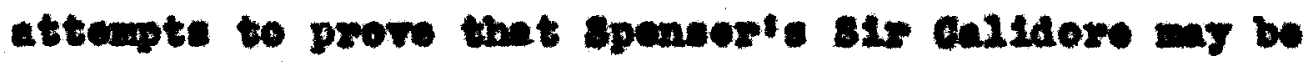

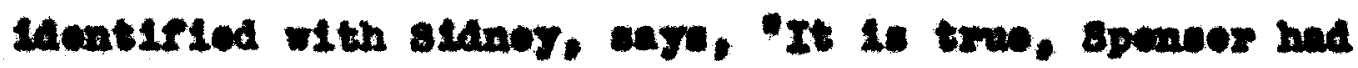

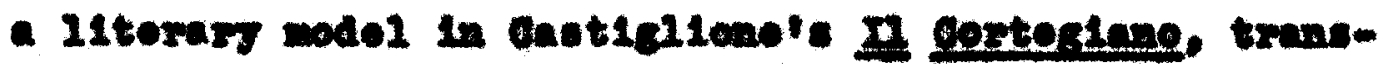

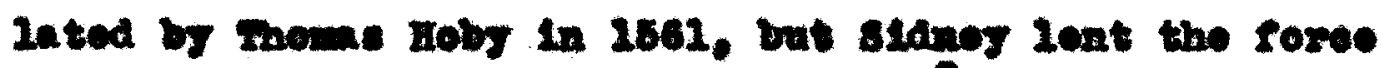

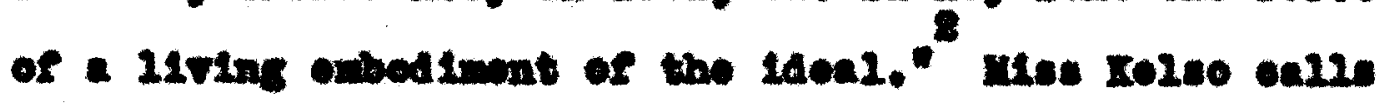

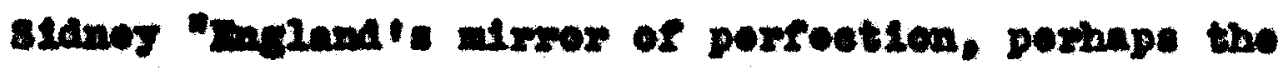

2

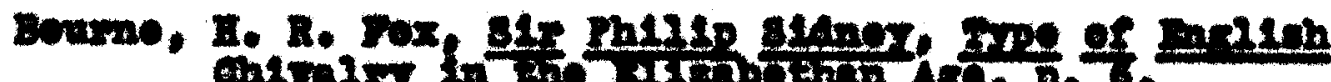
8

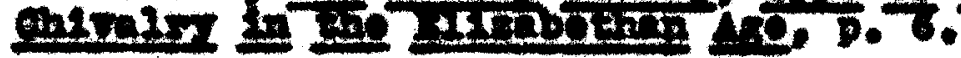

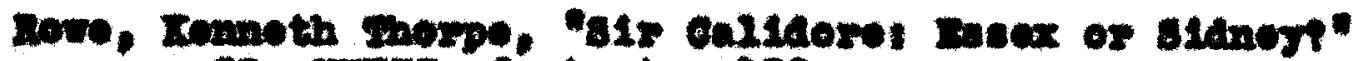
8P. XNII, rootnote, 130 . 
marest appronoh to Gastigliong's lend that tho

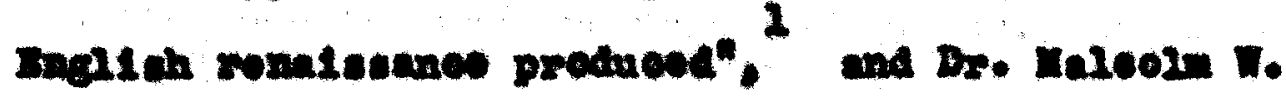

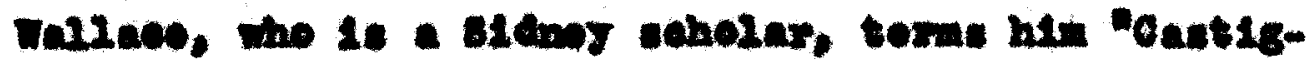

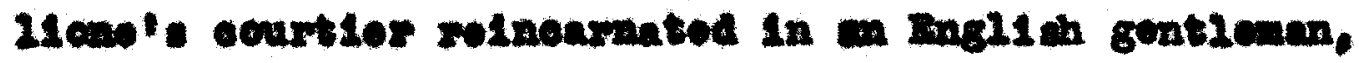

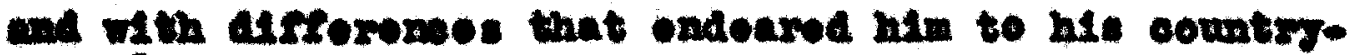
man. 8

Wth of much roforonse to BIdneg an the Castigliono 14od, I covid not rofraln frem wondoring

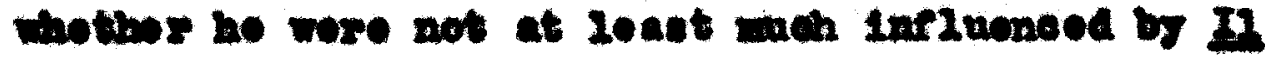

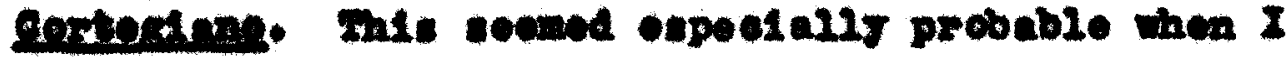
man aeroes a otatemont to the effoet that aldnoy "nevor otterwa abrod without a copy of tho garntier in his

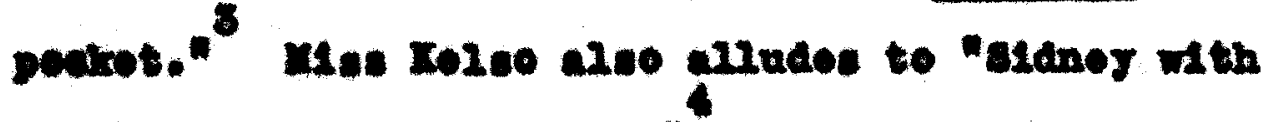

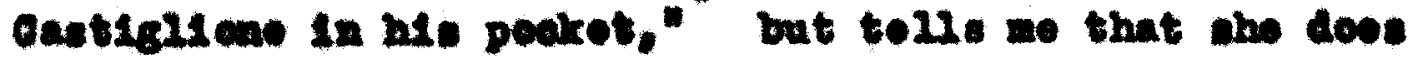

2

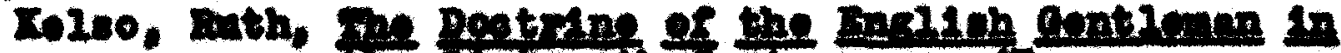

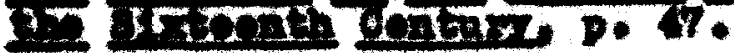
2

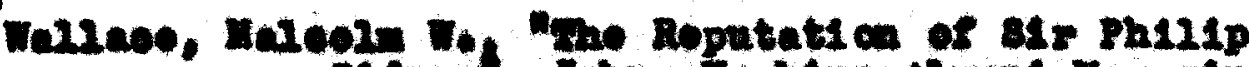

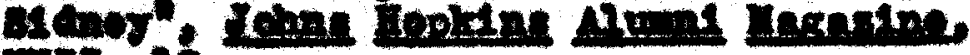
2xix, 2 .

8

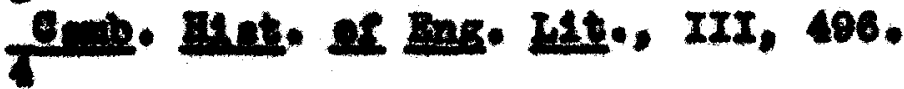
20200, p. 88 . 
not remonber where the reference come from. Dr. Wallace also tells mo that ho thinke the atatement one of those pleces of embroldery whioh mange to bave themeelves adopted widely without any s011d foudation. I have been mable to find any souree for the stateront elther in ocatemperary or secondary material; so that it will have to be disecounted as or no value to our study. Bo thet as it may. It is very probuble the sldnes was raviliar with Gastiglione, -1thor in Itelian or Ingliah dreas. The sidney family was on terwe of Intiwey with the family of 81s thomas Hobs. the trannlator of the courtier. ${ }^{1}$ and in Dotober, 1575. Ph111p took part in the baption of Iady Hoby's eldest enild by a second marriage. Horeover, thore was no book better known to the eourt eirele of s1dney's dey than the courtier, as I shall hope to show. Whothor

1 wallace, Haleoln w1111am, The Hife of sir Philip 2

피… P. 158 . 


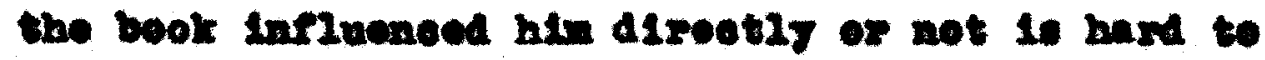
cotoralne. For that matter, wo untreran217 was it road, thet thore covid be no linit sot to the ine

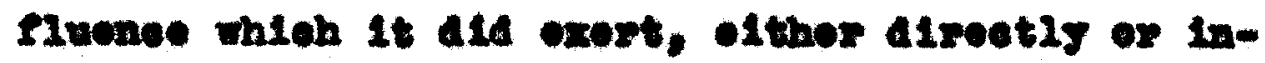

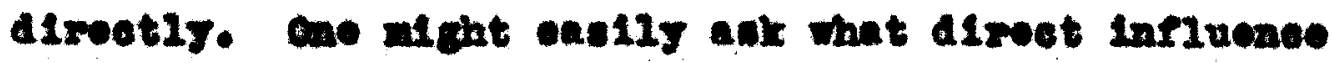

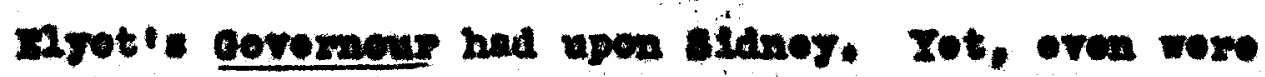
ouch influones proved, wight it not casily hask

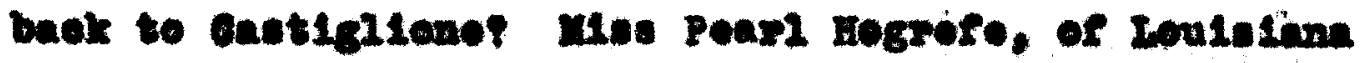
Polftechnis Inotitute, hat given sow very woxthindie oridenoe to indionte that nyot know tho gourties in

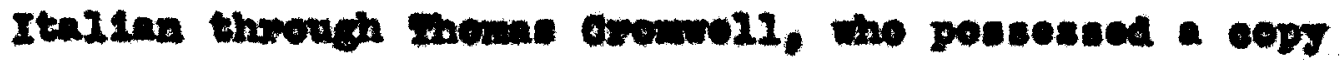

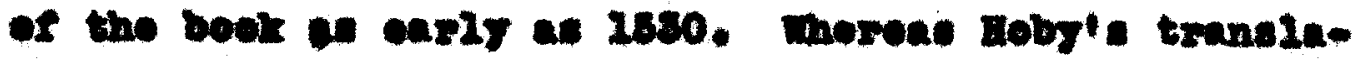
t1on was not publiened ent11 2561, the book in Italina was publichod in 1508, three roars bofose Irot's

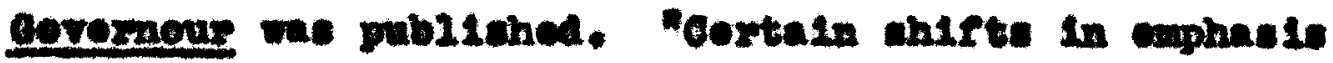
In the mitincen of nrot frem those of bolot, now,

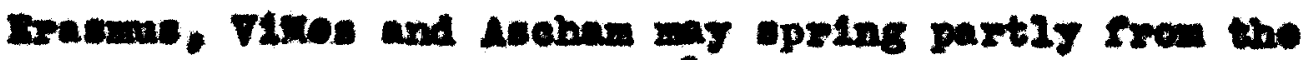
intinonee of the gowten. ${ }^{2}$

2

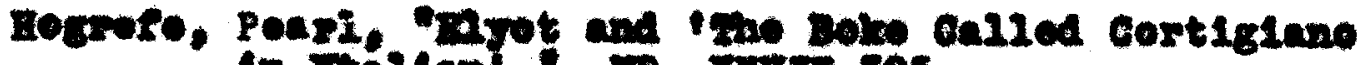

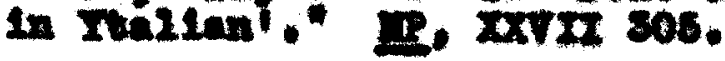


Whothor sidney was or was not inriuenecd by the Gountlez is diffloult to say. Howeres, it is possible to ascertaln in what reapeots ho conformad to the Laoris of Gastiglione' gourtier, at a time when the Italing ldeal we pormesting burepe. I hed for some t1m opeoulated upon this when rise roleo's treatise on the Dootrine of the Drel10h gontlomen in the slxteen-

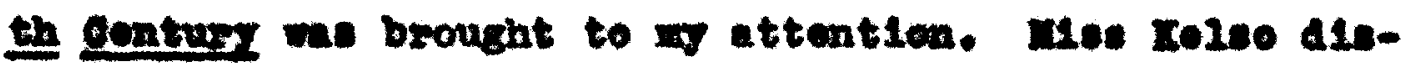
tingulanes olearly between the Italien laeal and the now Inglioh 1denl ovolving as a zesult of the 10ngcontinnod poses of nisabothis relen. With this in mind, the Ieading question now socen to be, In what roppests did sldnoy oonform to the Itelian ldeel and in that waye

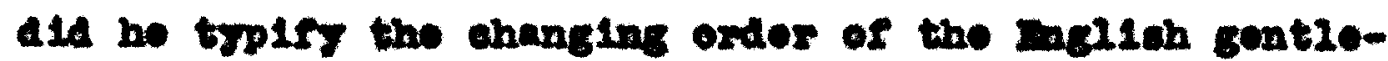
mep is an 18 ores of this quostion, is those anjthing in bie mitinge to indieate the poselbie infivenes of Catiglioner

Partioulariy, at a time whon lovemenking wes not recomended by ragliab writers as a part of the gontie-

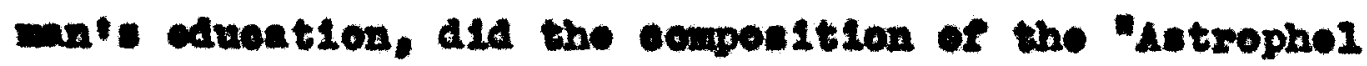


and stella" somnots help to plece sldive on the

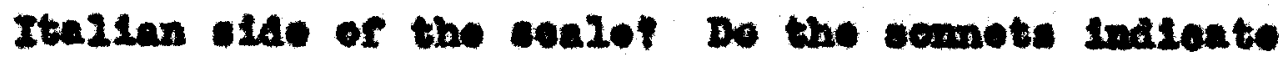
- Incere love for Penolope Doforune, are they morely intetive in charector, or are tho exnyples of Pletenie lover If ther are Platonle, the key to

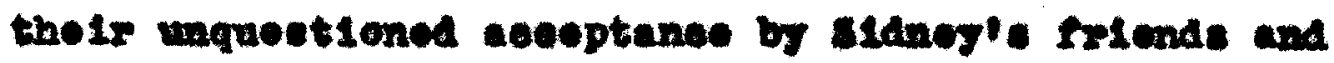

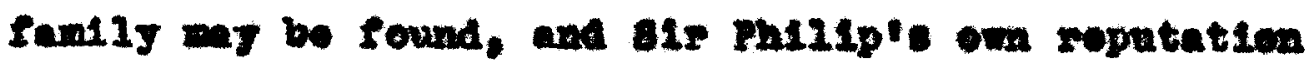

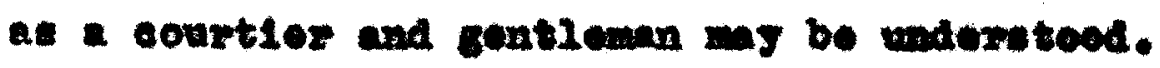

Int, puteling aclas the alfromentintion botwoen the Italian and bagles otaveards, did sidnoy

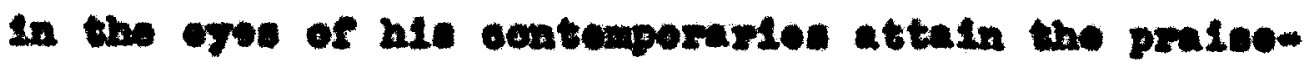

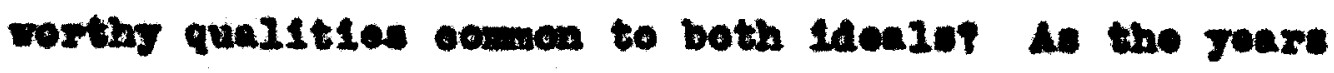
have passed, treattion has grown up about himi jot. the one trie gaide to hls oharaeter and hle ablitty 10 tho opinion of his contemporaxies. I ohall atterpt to whow that those conteruperasles were elequent and coemingly elneore in tholr praises of him, omatting that he worited cueh honor and seteve, it is safe to asewn that whotber he more noarly eonformed to the Idenis of the couptior of of the gentremn, ho mant 
wedoubtedis have possosach that most coumendable chereoterietis comnon to both typee - Virtue.

20 determine slanert pealtien then, aoconding to the atandards of the tims. I shall dovote the riret ahepter to

- A glimper or an Ital sanated magland witeh road with avidity Italian ecurtesy books, partiou-

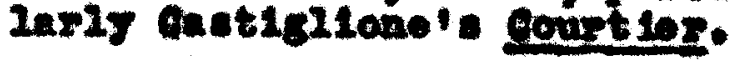

b. Th lacal Italian courtior. as sinetehod by Gatiglicae.

c. The now tanglinh gentleman. difrorontieted frem the Itallan courtier troe, as oet forth by rise rotso. 


\section{oncurat $x$}

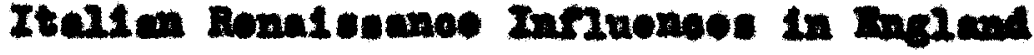




\title{
OMAPRan $\mathrm{x}$
}

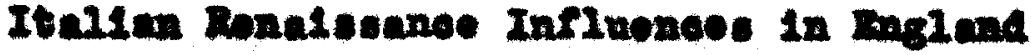

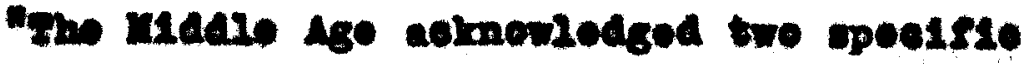
tspes of edueatient that of the knicht and that of the elorix... Inth the advont of a new eanopt - the oxprose expation of Italy, or, at 2oust, hor rodecorery - of wan as a lajman, notthor colder nor elert, of wan at an Individual, not a nanolese fraet1en of a group, pormonality becens the censelere goul of derelopmont." ${ }^{2}$ puring the meale 1 got orery cast Io had boon alniature court, but now the deninant politioal feature of the age wat the coneontratien of the supreme power of tho etate in the porwon of one soverelgn prines, whose court becan a otopplng otone to tho groat carpors of anne, Adplonacy and admind strative omployante. more Italy 10d, wootorn Burepe followod,
\end{abstract}

2

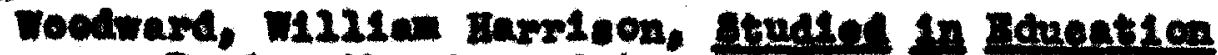

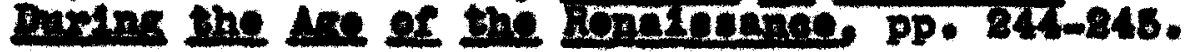




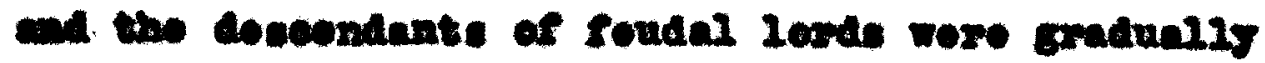
trancforab inte conrtiers, as the soverolgn power of thol king wat inowosed. Italy was the pattom in all phuses of apotal 21fe as ravis it in tho world

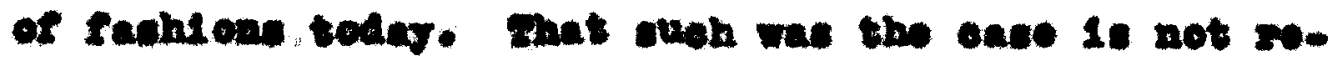
narkblo, for in Italy the Dotward eppoaranee of non and wenem and the hablte of dal2y 21 fo woro now porkot, wowe boant1tul, and pore polishod than mons

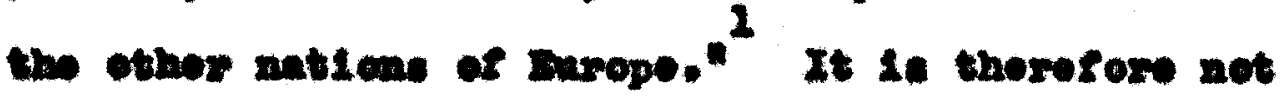
mearkab20 that Itely. chould hare beon tho birthplese of the cempong beak.

Wowne the ond of the I1ftoonch contwor Itallon influowes bogen to appoas at the Inglich

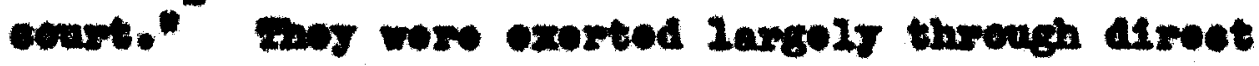
Intereoures botween Ingland and Itely, and throuch the bransiation of Itallan books, oppecielly of owh

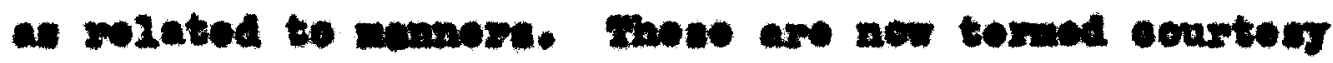

2

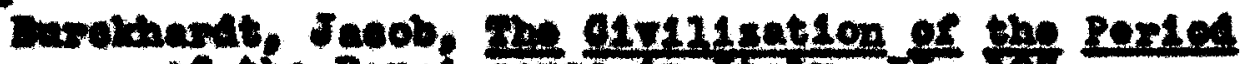
8

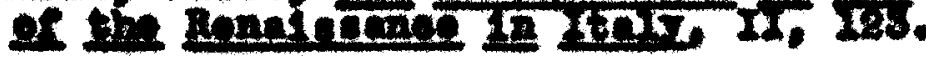

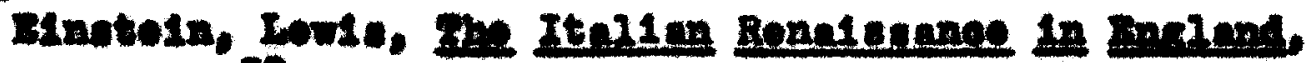
p. so. 
bears. "A now trpe of courtiex had grown up in Italy. At the ceurts of Brblne, Iantur and Forrare a Mighor concoptien bad boos formod of what the oempention of tho prinos mote to bes his mennors and cecenplichnonte boewe an patward sorkestion of the

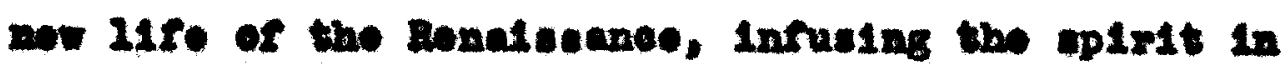

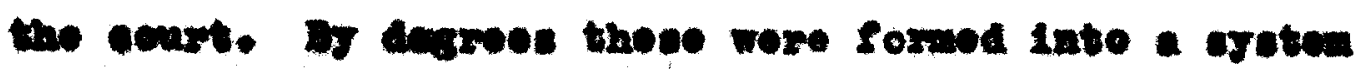
ready to be tanght as part of tho oourtior' odusab1on."

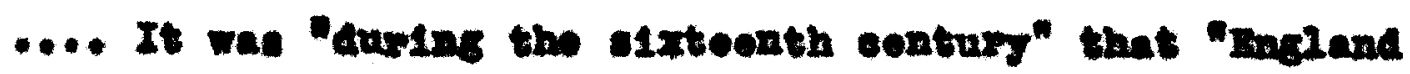

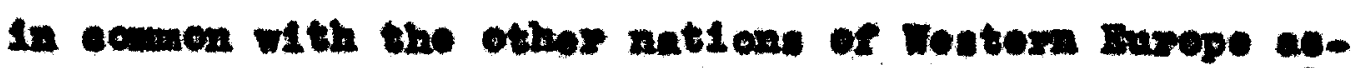
quired conaterable smiliartb with this now trpe."

It Is not atrange that the melend inion edopted the Italian courteng book as 1ta bible of otLquotte chould have beecme "Italianated". In oporte abo madted to Italien wothode and Inotruetion. Inglioh

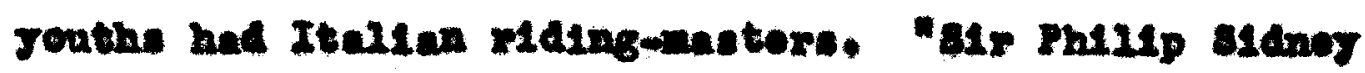
bogene the patron of tro Italian ralngmantore in

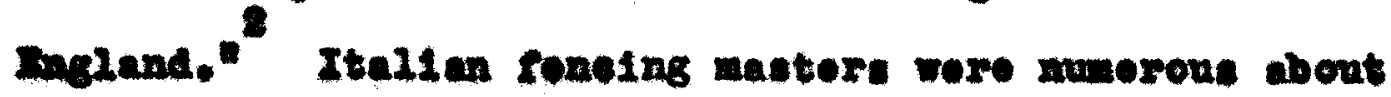

1

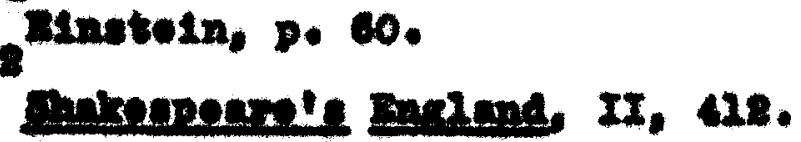




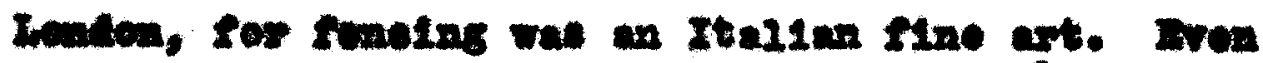
2

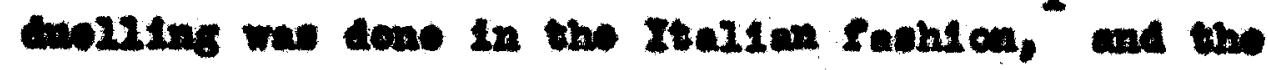

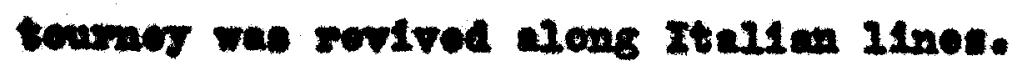

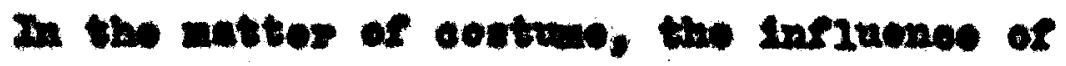

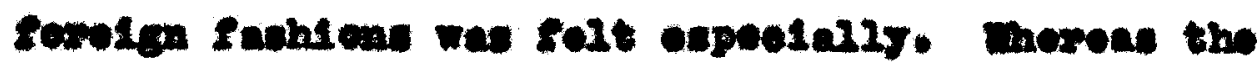

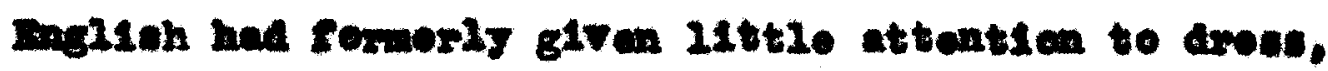

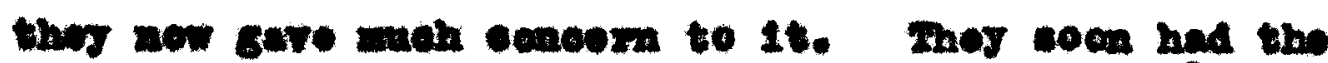
nowe of boling tho wost intetive race cu carth, botng

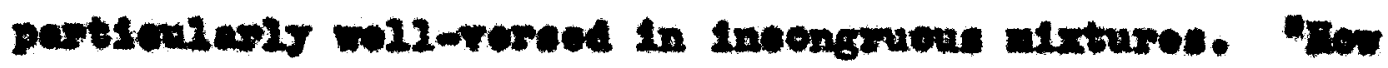

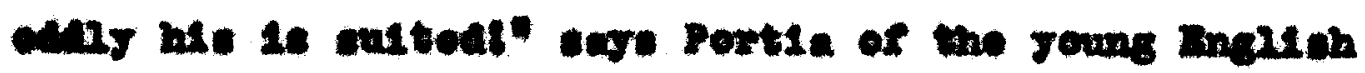

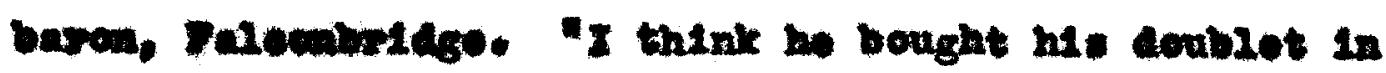
Itely, hla porme hose in Franeg, his bonnot in dosmany. an he boberiou overrineze."

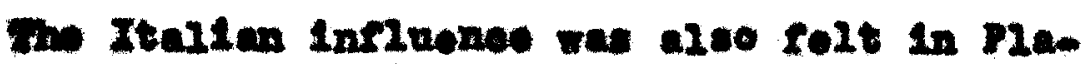

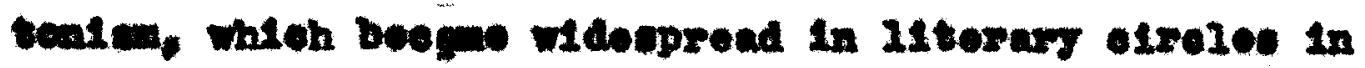
the elxtecuth century. Potreoh was rogarded in his ow

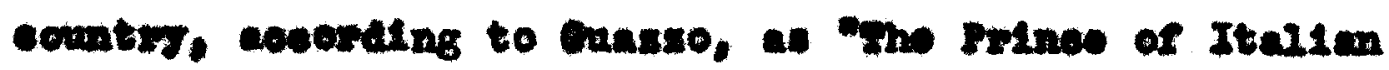

1

nivotedn, p. 70

8

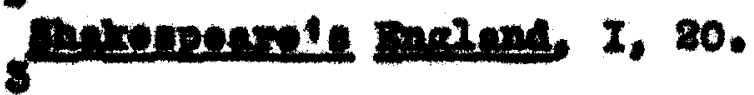

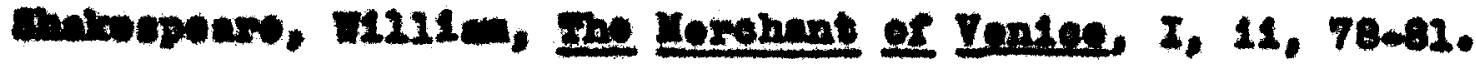




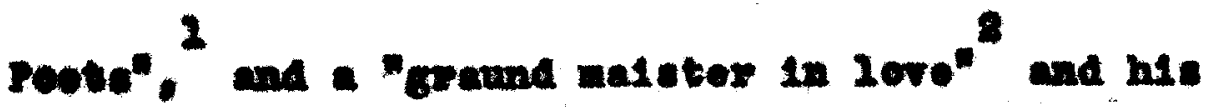

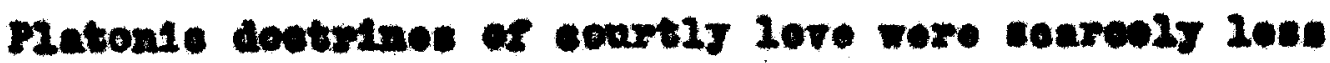

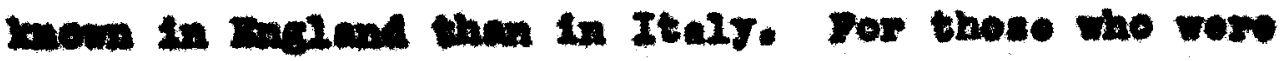
wable te road Italien, the tranulatien of Reol's

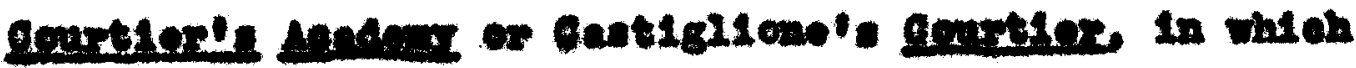

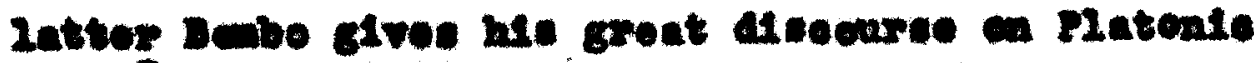
8 10vo, wow eceoetble.

Even the Itelian lmanage was affooted, bolns

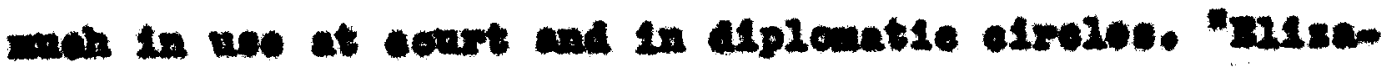
both horoole had loaraod Italion en a chila, and Doger

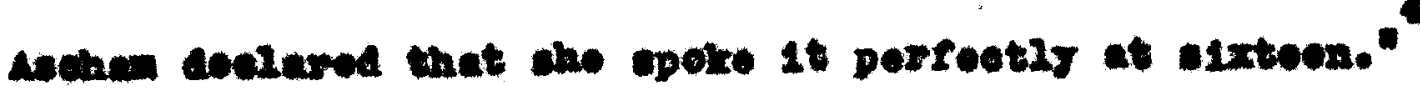

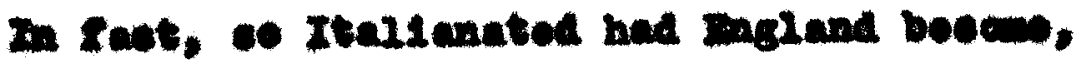

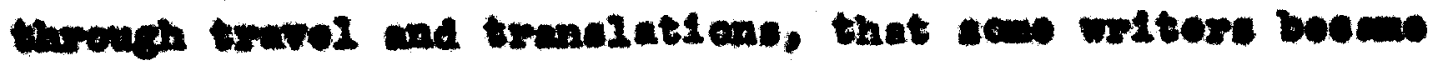

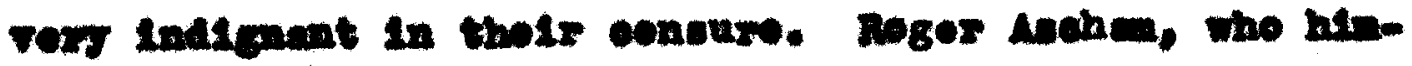

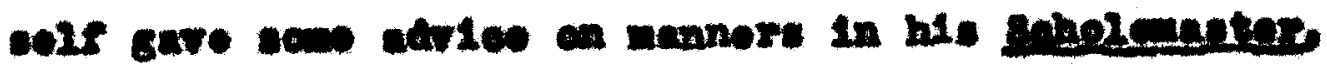

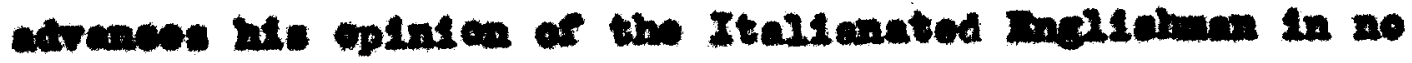
woortuln texine.

1

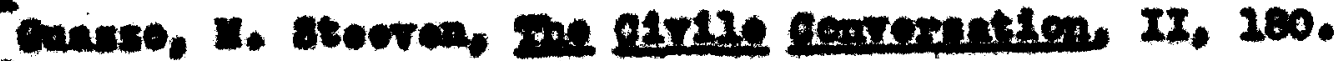
8 201. 204

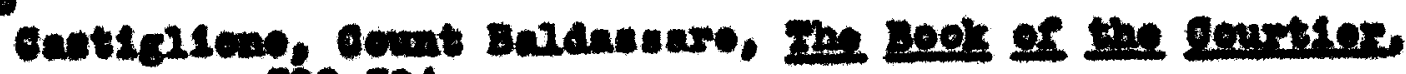
4 pp. 308-324.

Inntoln, p. De. 


\begin{abstract}
Wis, that by 117ing, and traveling in xules. bringeth ho into sucien ent of Italio...tor Roligien, Paplotrie

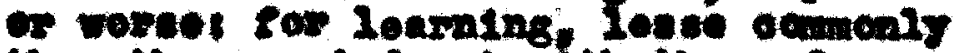
thon thos oaved ont with bent for

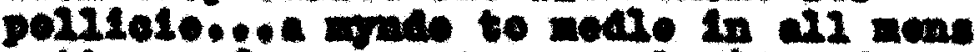
mattorel for oxporsenes, plontse of nor

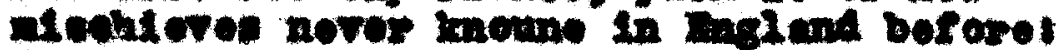
80. manose. variotse of vatites, and

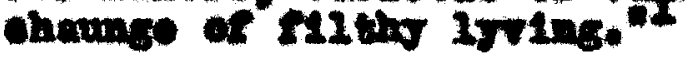

whe ohice Italien eourtoog books trpmelated

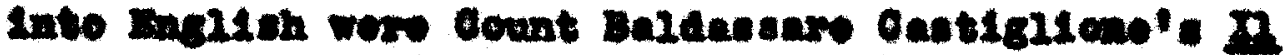

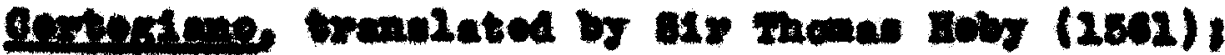

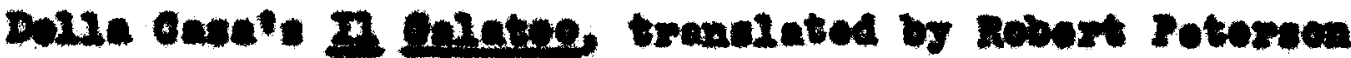

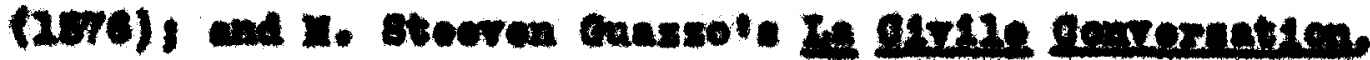

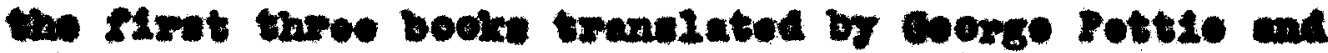

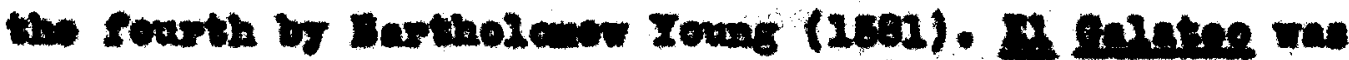
In maxty inteadod for the nidare anase, beins a

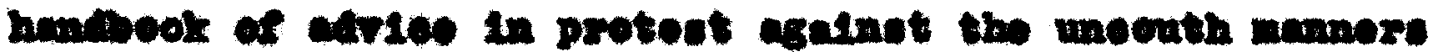

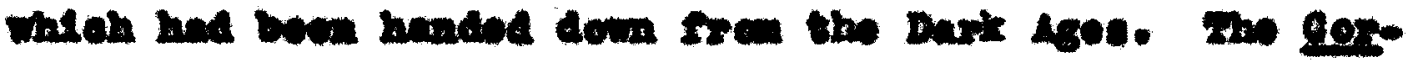

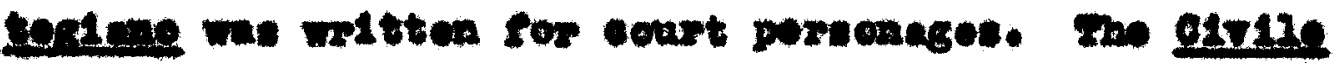

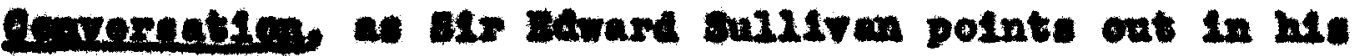

2

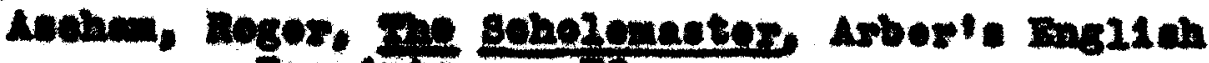
Bopintro, po 70. 


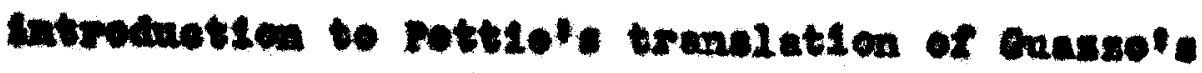

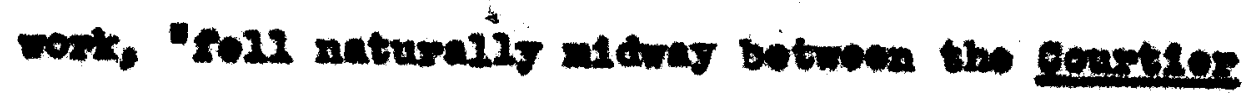

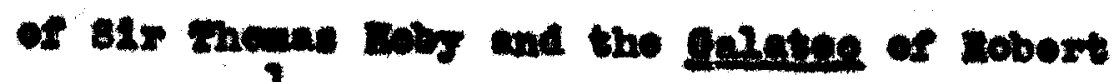
sotomen. ${ }^{2}$

That those Itallan booke wore somatst

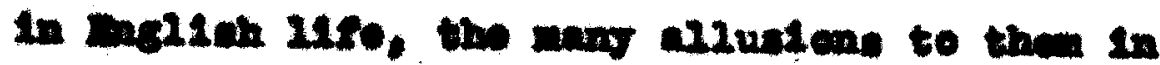

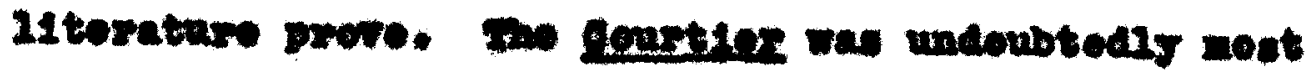

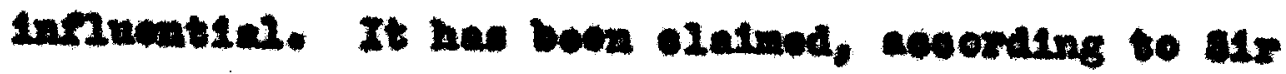

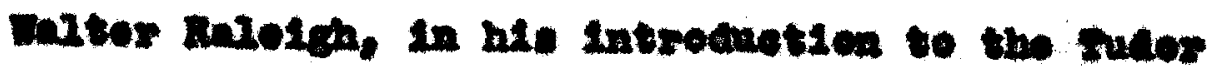

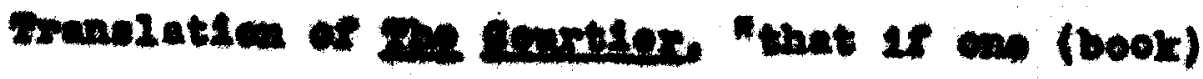

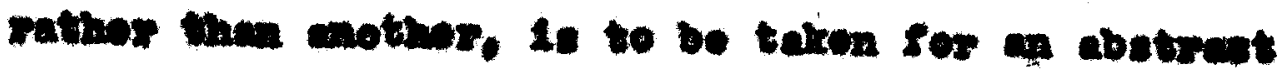

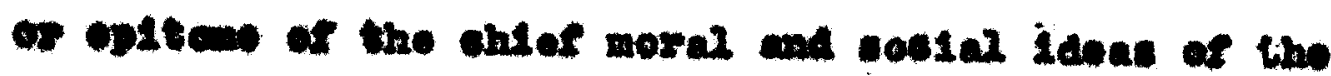

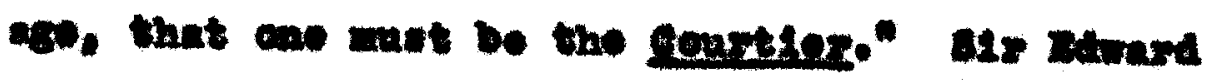

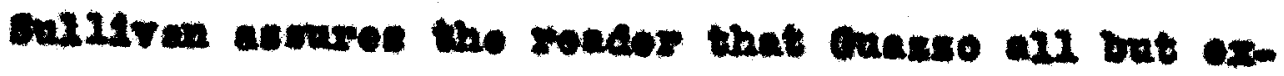

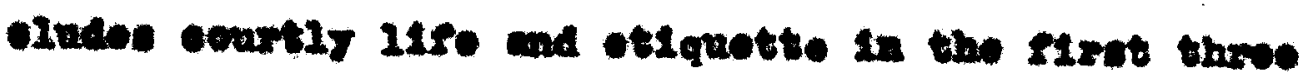

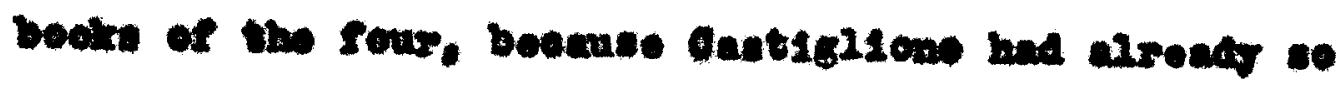
woll troated the subject.

1 Cunse, $x_{2} 80$. 


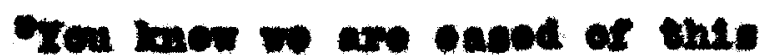
Inocie by hill who with his loamed

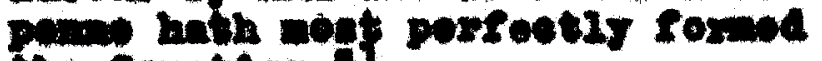
tiv ocurtios. 1

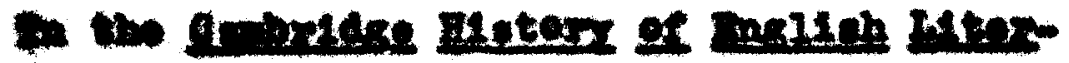

Ature is frone the stateronts

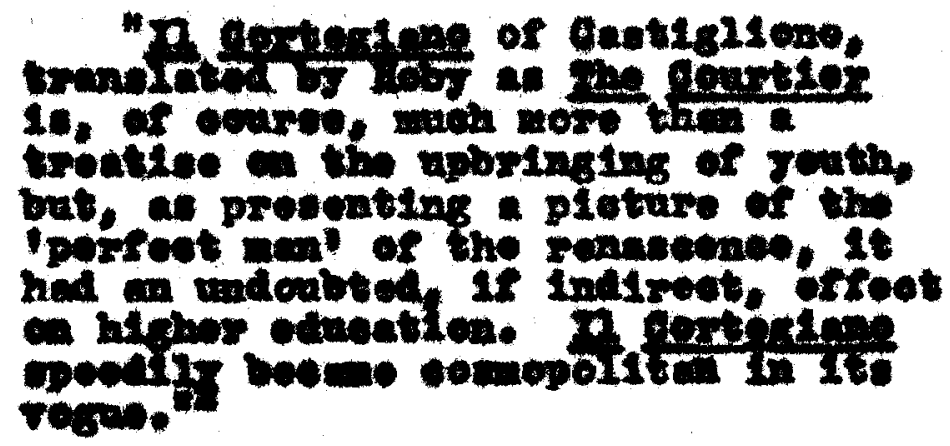

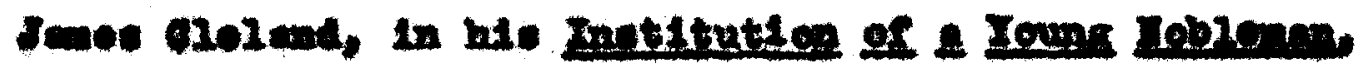

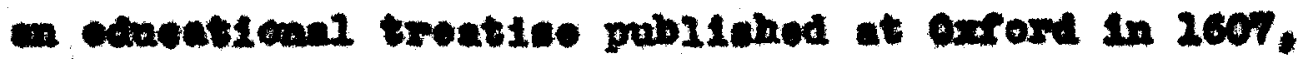

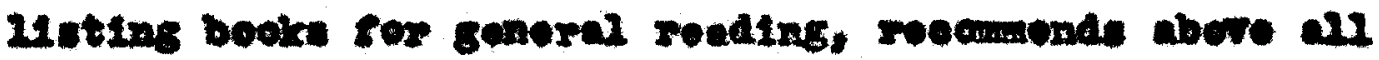

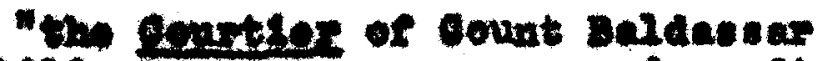
cavtule o rory nocosenry and prorst.

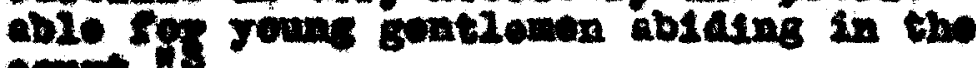

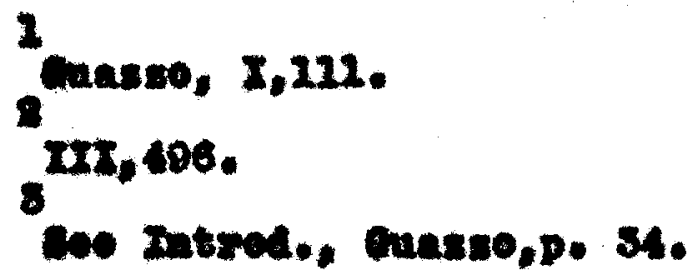

1

Cuases, $x, 212$.

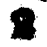

2xi, 406.

8

Coe Intred., Ganse,p. 34. comsen.". 


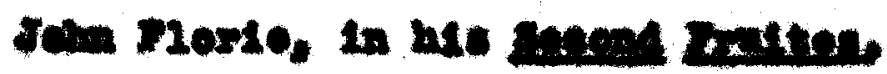

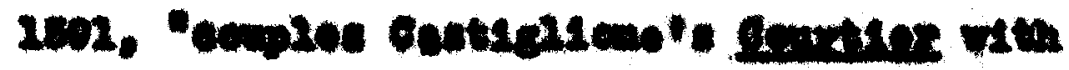

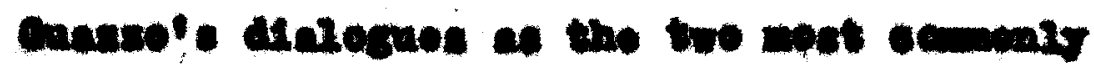

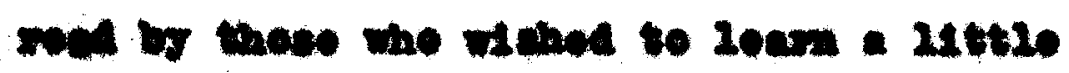

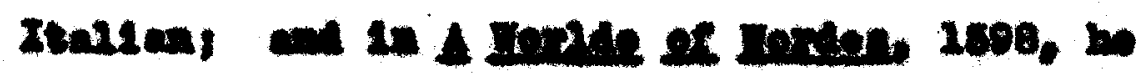

poake of wellefownarle etudents that have

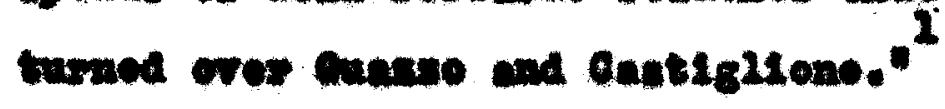

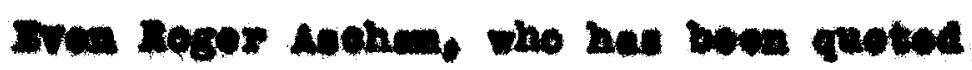

as bolng row waih opposed to all thinge Jtallan,

$\therefore$ sate of the enving

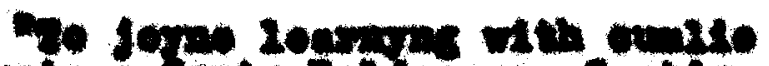

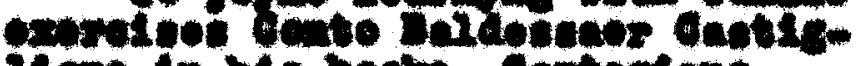

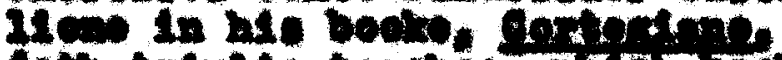

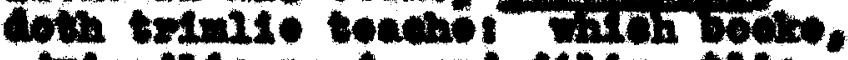

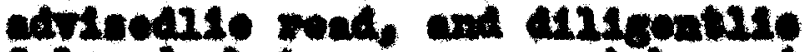
colewed, but on, joum at here in

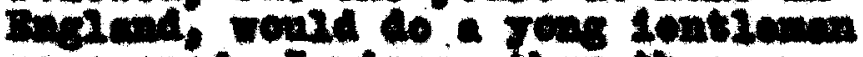
0020 sood, I dites, thos three jeares travoil abreds opent in Itullo.".

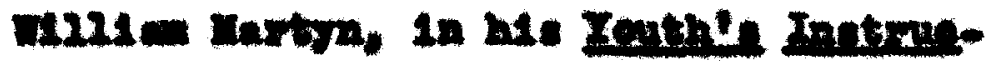

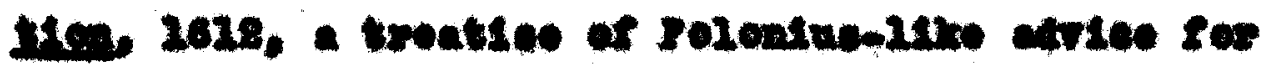
Mit som, rowennmer,

\footnotetext{
2 Introd.. Easeo, p. 84. Anction. p. C6.
} 


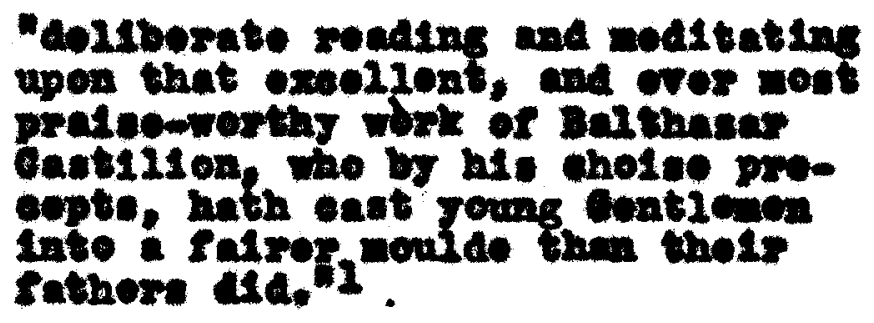

II Is Iolse polnte out that the anthor

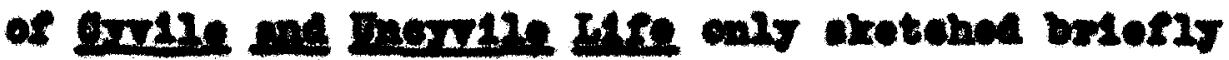
the life at pourt, rescmonding nob's gartise ror cotsuts.

In view of cueh widoeprond favor, it

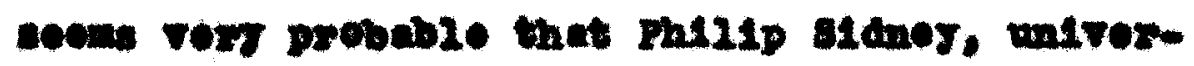
aty an an courtior by profoucten, would haxe

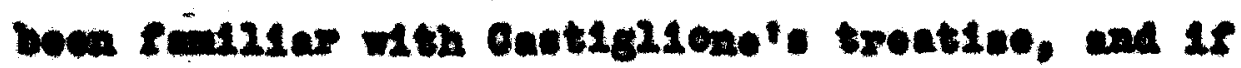
w Find that ho conforme in mory ware to the Italion 1deale, it 121 not be eurpeialng. $\leftarrow * * * *$

cownt Baldanaro Oestiglicas was woll propared to write a aketeh of the Ldod court1or, for he htrools was actinotively a gentioman and a

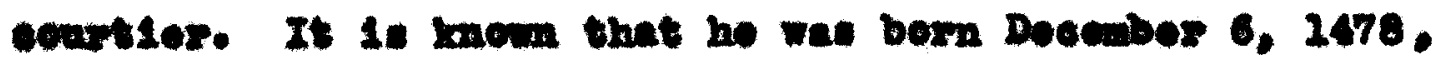

\footnotetext{
$\mathbf{3}$

soo wright, Iouts B. "Iandbook Learning in tho 8

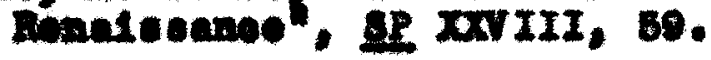
I0100, p. 82.
} 


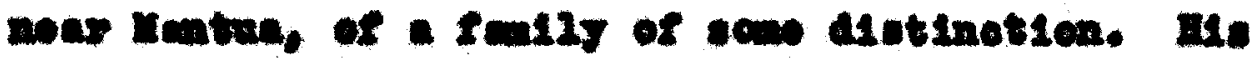

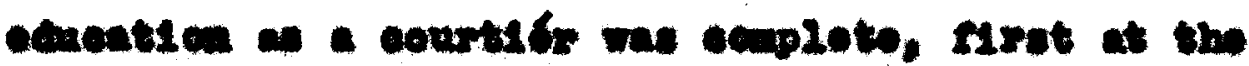

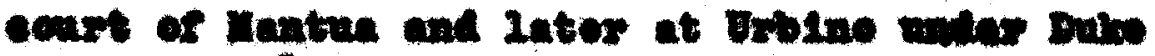
1 culdobare.

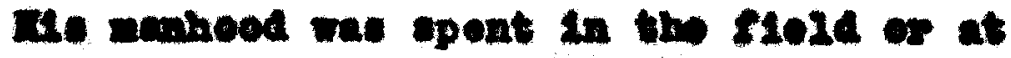

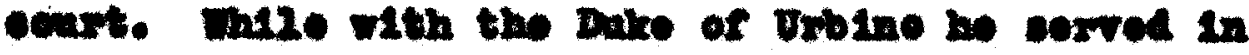

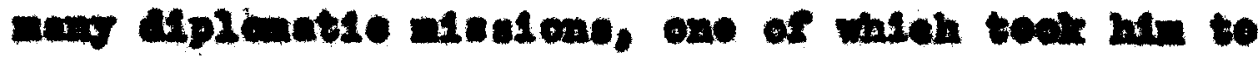

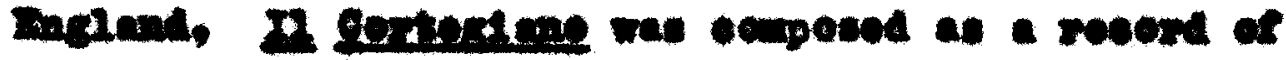

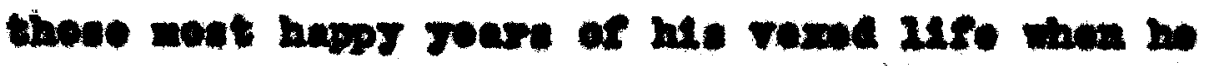

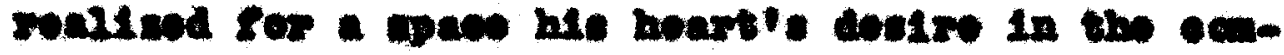

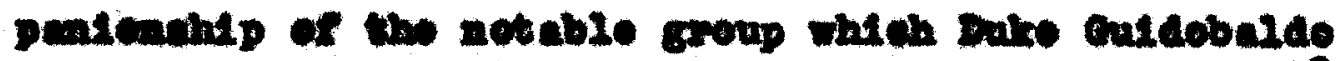
and his dharning buchese breaght tegethor at brbino.

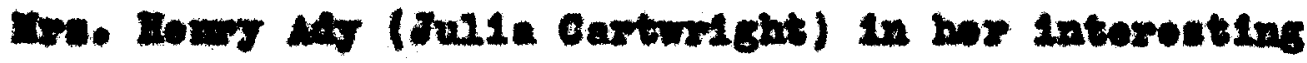

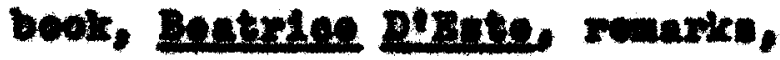

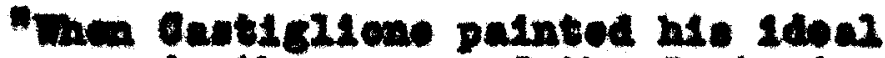
wan in the pagen of the gertertives. we had ne nogd to drm on In inaghe-

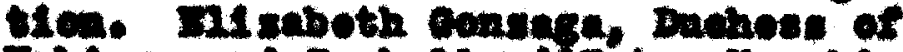
Erthe, and Inabolia alstes. Inrohion. -ae of rintre, wore both of the vingm

1

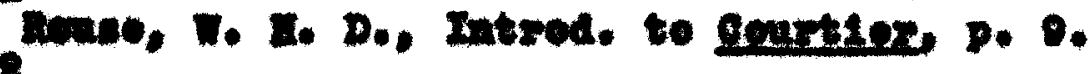
8 Wooumand, p. $8 \mathrm{sl}$. 
of great intolloet and otainzese

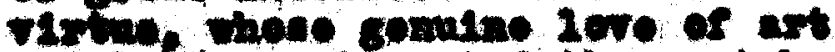
an 20ttore attracted the nont bene-

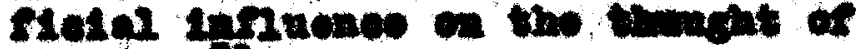

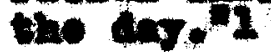

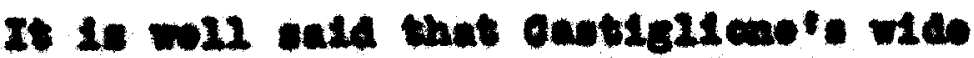

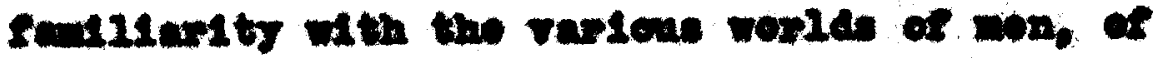
wenen, and of art, cone tren he seatin rolations. The okteh of the ldod courter we

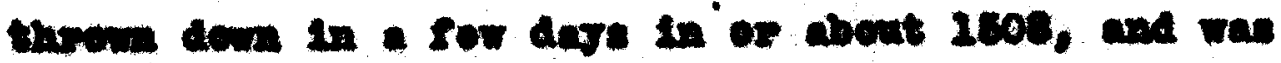

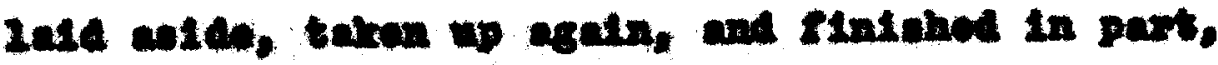

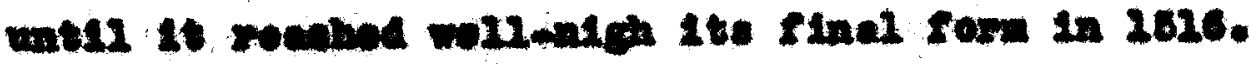

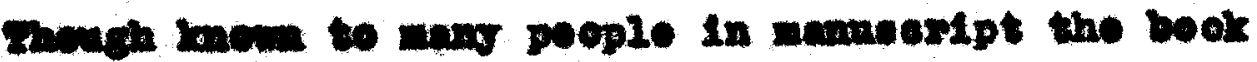

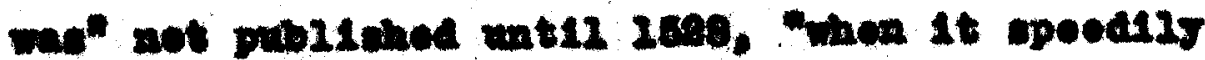
boeme one of the best rosd werke in burepe. It was

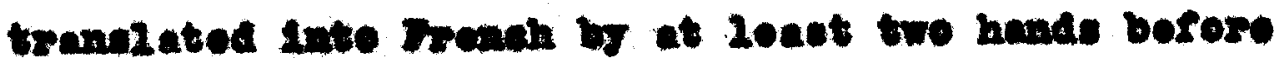

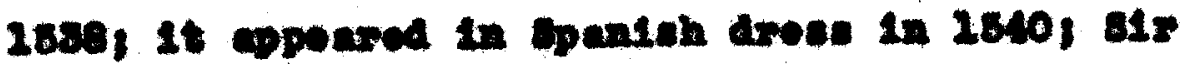

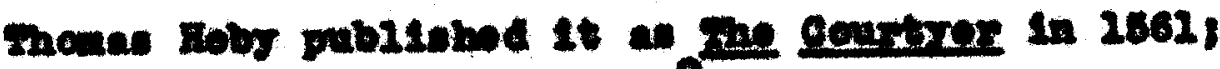
and it was put inte Intin."

2

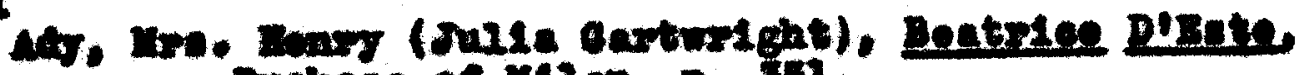

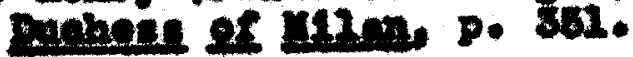

8 noedraxd, p. 862. 


$$
-\infty
$$

The eotting of the oronts recorded in

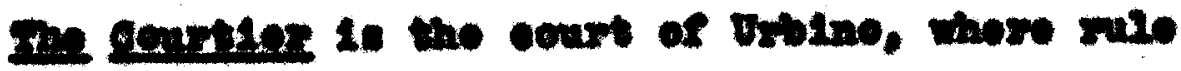

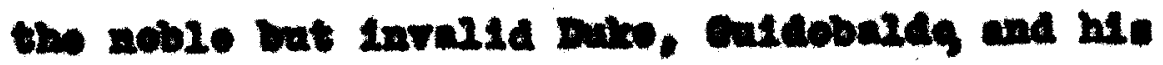

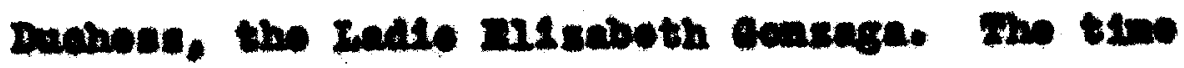

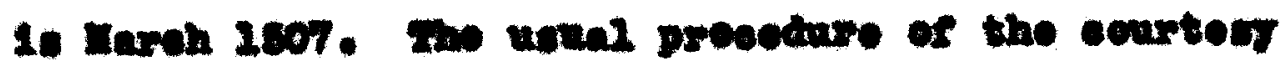

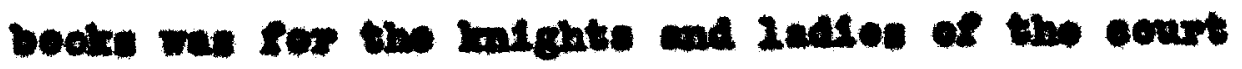
to noot in the crenting. A quopr was eloeted from

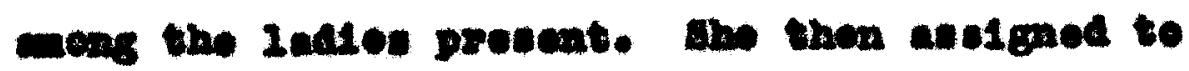
the dufromot wemere of the cempon a top10 of Anousesen. In tals namor the important cubjects

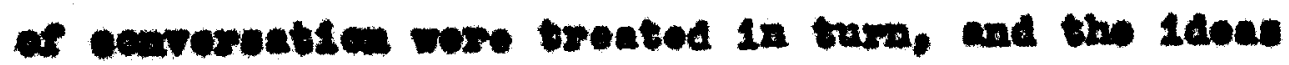

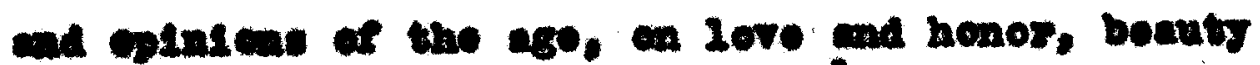
and richos.. were all expresecd." ${ }^{1}$ at the eovet of

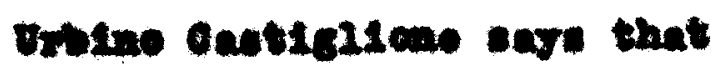

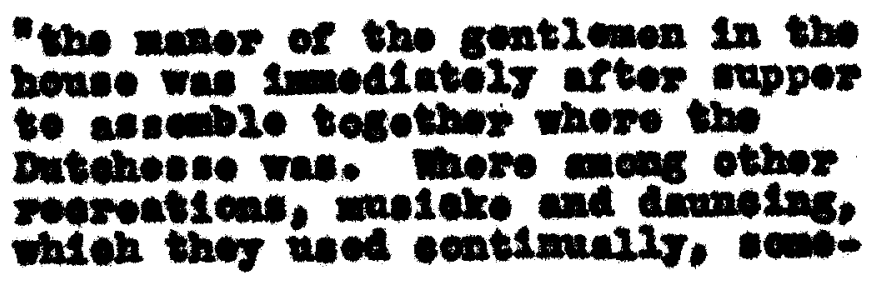

2 ninotetn, p. 8s. 
tive the propomed soate questions,

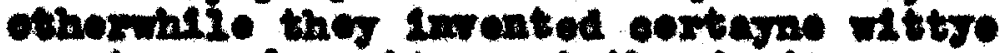
pportes and pastimes at the evrieg nono. tine or ane, ecentime of enothos, in

Tho Lade Da11. P1a, Irtend and expenten of the Dachose, unally aselened the patimes.

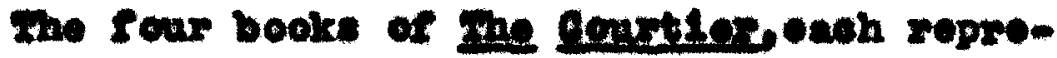
contlag an croning's toplo, are conoerned roppectively wth the qunlifieations of the Idoal courtien, the

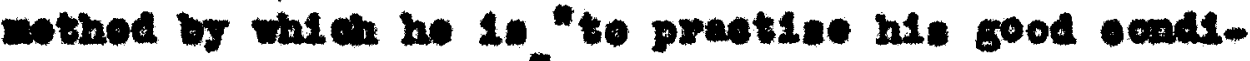

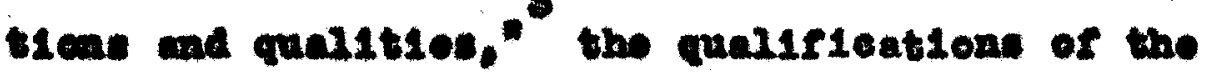

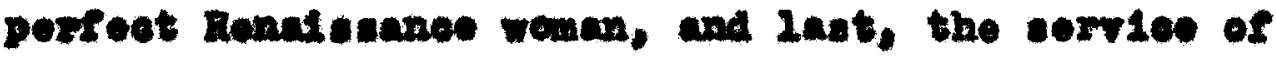
the courtior to hls Prince, and the proper teotses for the courtior in mattern of 20ve. The suggested pastive wich brought forth those four diteusalons, on four consecht17e woningt, was

- te abpe In rordes a cood courtier. opoelfying all rech ceuditions and

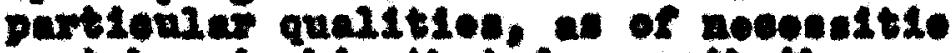
mote bee in hlu that deserroth the nem.

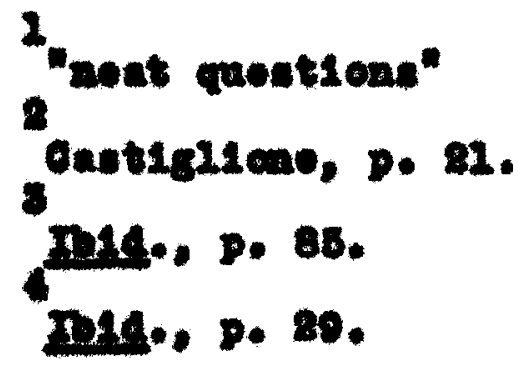

2 "not quotioan"

8 onotiglleav, p. 81. 8 1014. D. 8 .8. I4. p. 80. 
in othos worats,

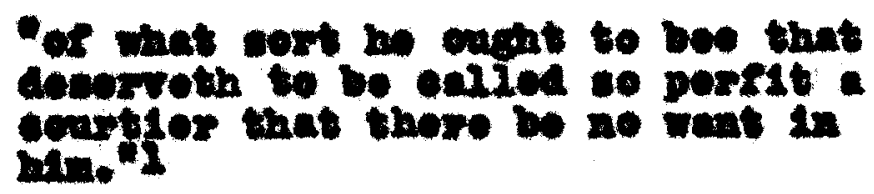

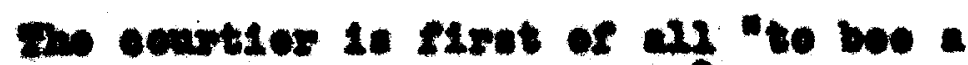

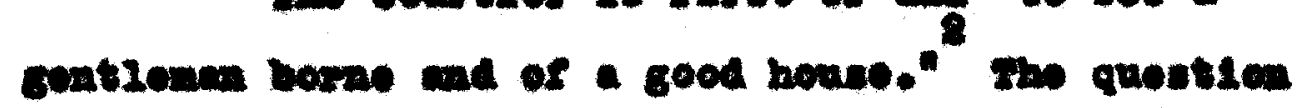

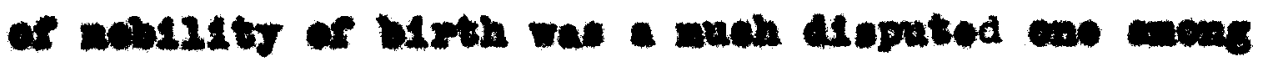
the anthore of the courteng books. In polnt of faot, the trond of the temen in Italy was toward more domooratie 1deas. AII wore agroed that thouph a seartior

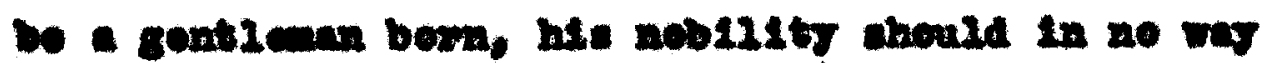

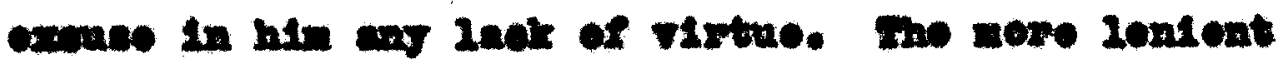

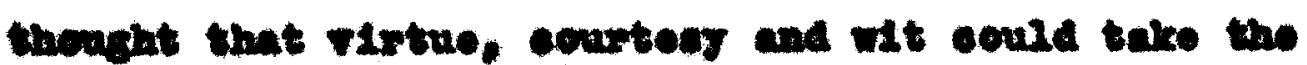
place of noblo docepnt. Eeme, Cnotiglione ineludod,

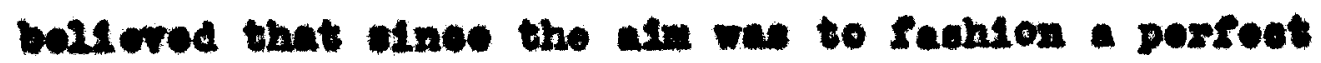
conrties, be chorla be of noble birth, elnee people ruppeoted noblemen far mero, gron though thats gral1t1en wore to now exeollont.

3

oatse110av, p. 28.

8

719. p. 81 .

B21.0. 4. 


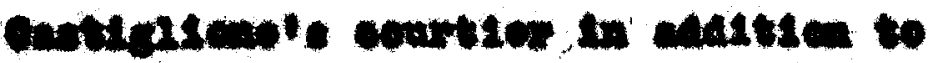

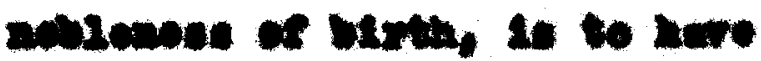

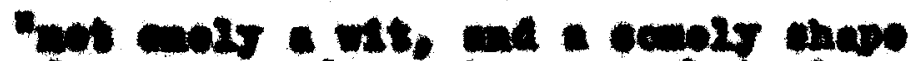

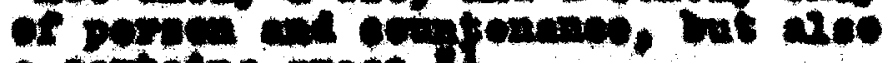
a ontro anew

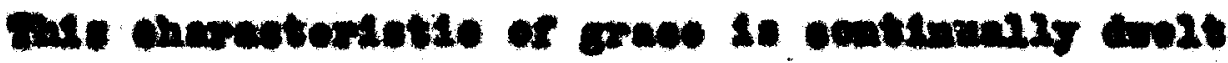

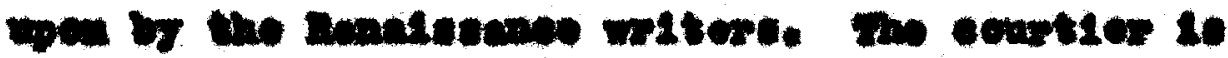

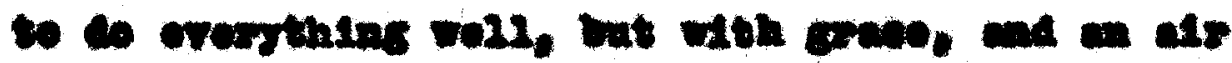

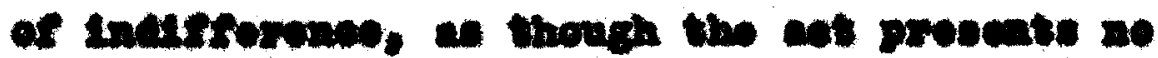

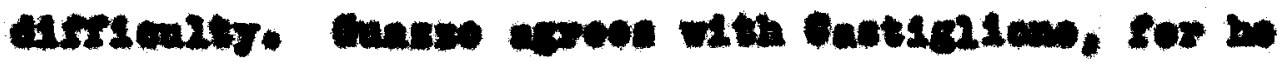

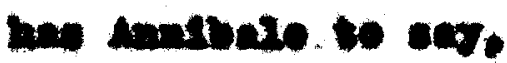

Exa nowe mowed aothing ot all in

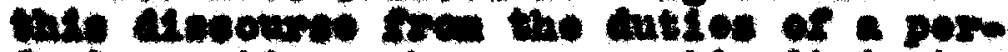

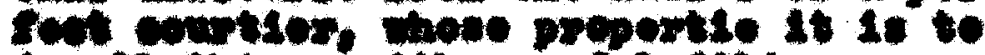

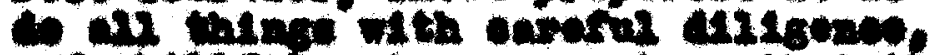

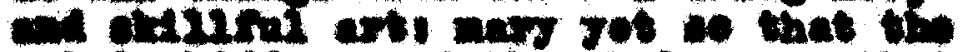
at If Maken. and the bove coenets to

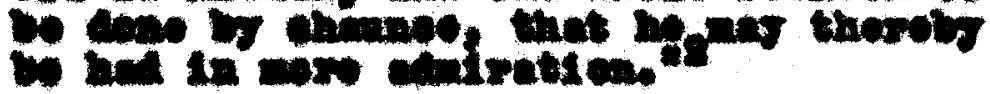

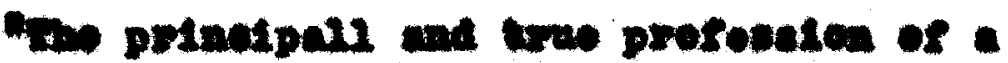

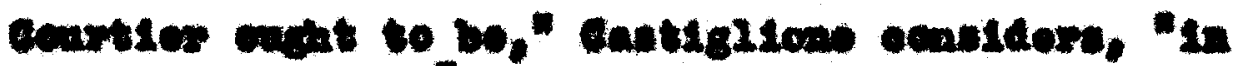

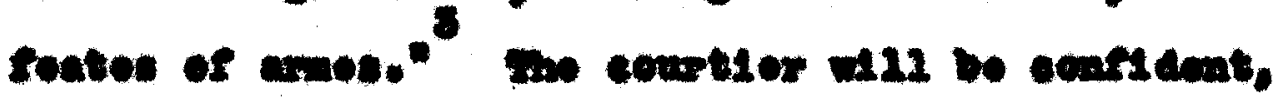

2

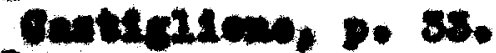
8 mases. 2.87. 8 conteghens, po 86. 


\section{$-26$.}

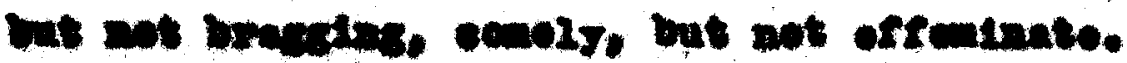

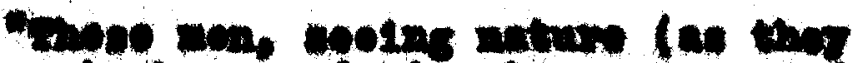

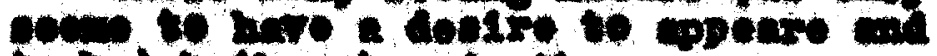

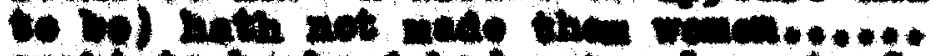

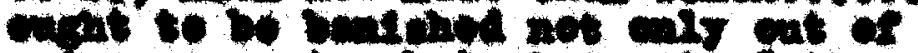

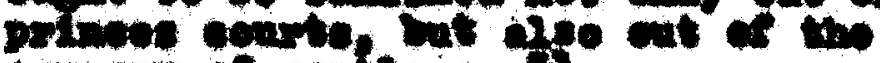

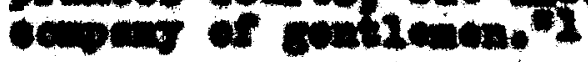

In ell operto tho ecourtion to "to mor

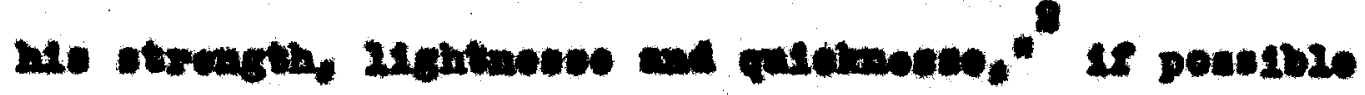

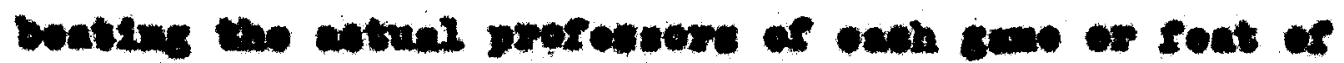

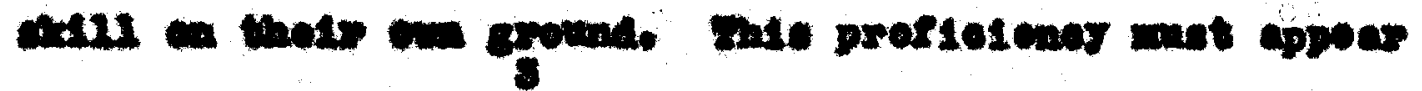

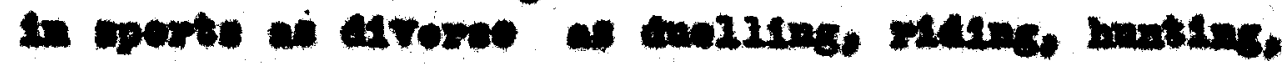

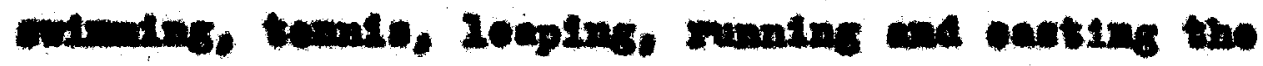

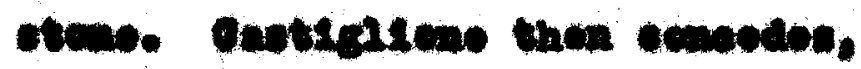

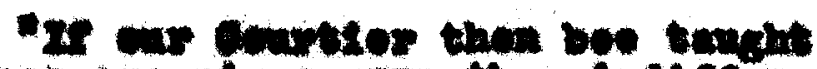

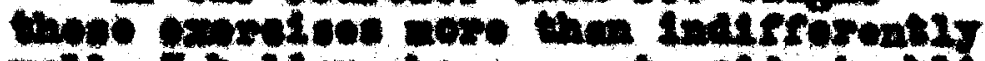

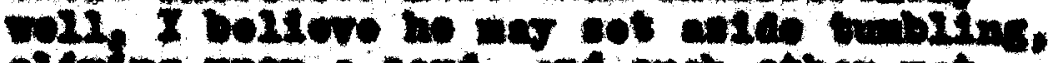

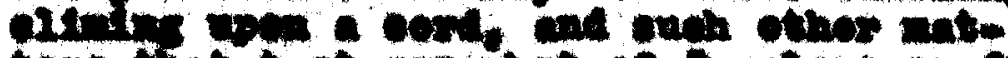

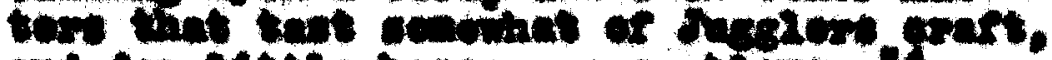

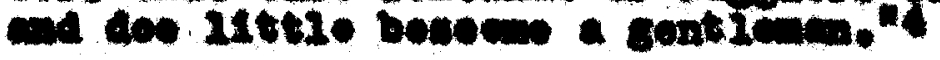

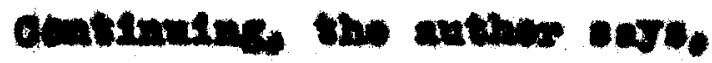

2

Gavticreon, p. 80.

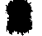

Ac. p. 40.

2.1... 0p. 40-48.

Min. $P, 42$. 


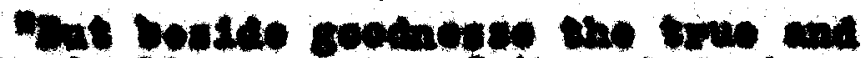

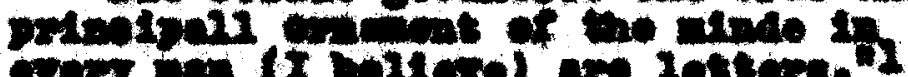

to wonk have the ecartios te hwo

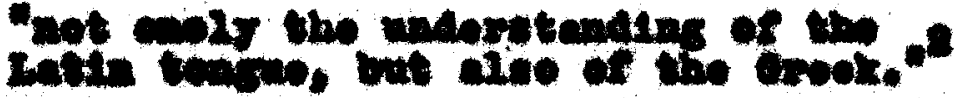

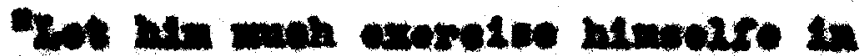

$$
\begin{aligned}
& \text { whter both ph and prow and ot- }
\end{aligned}
$$

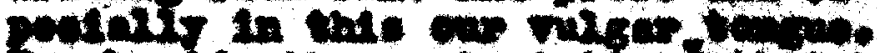

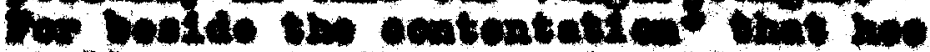

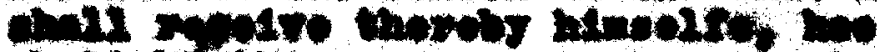

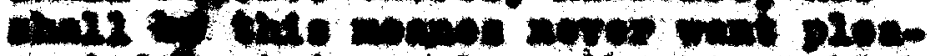

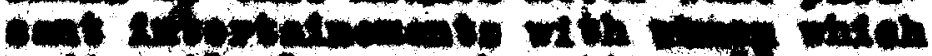

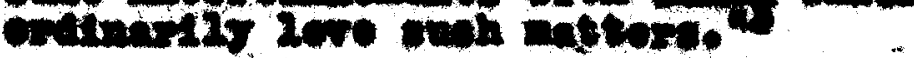

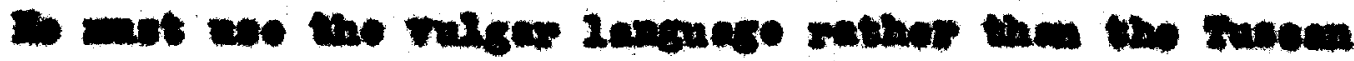

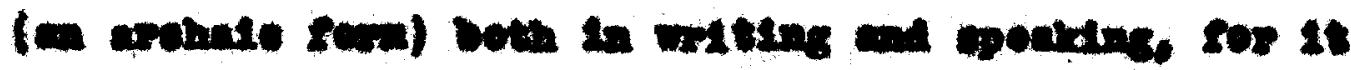

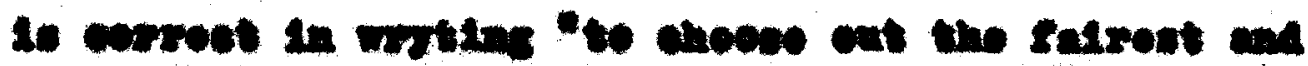

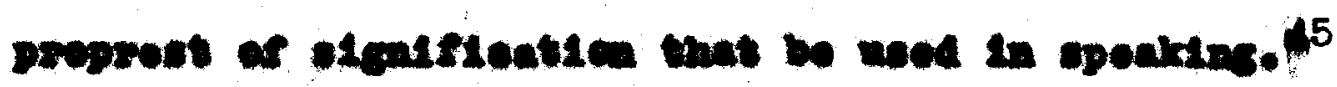

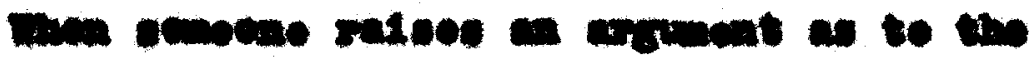

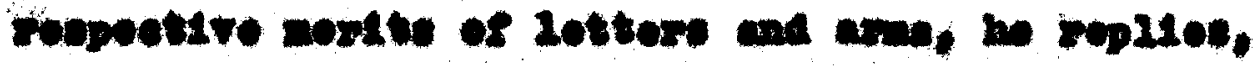

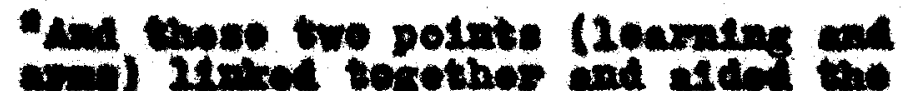

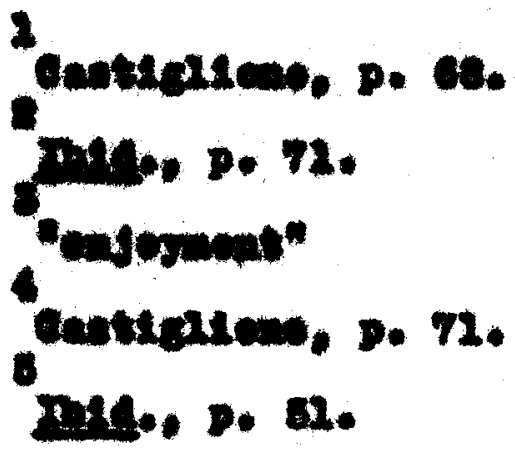




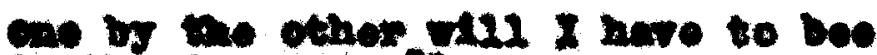
in in courter. on

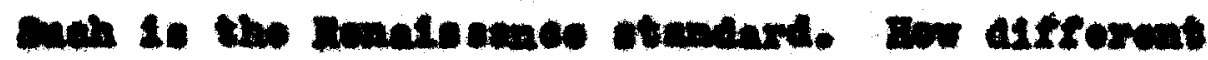

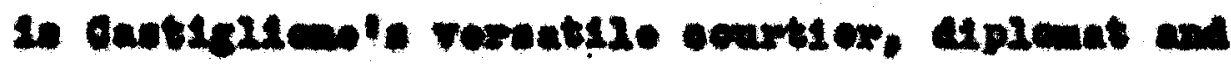

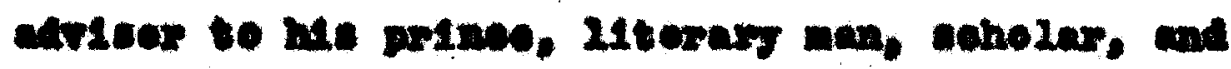

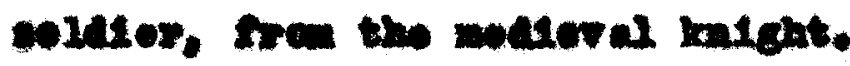

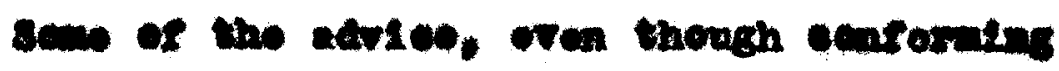

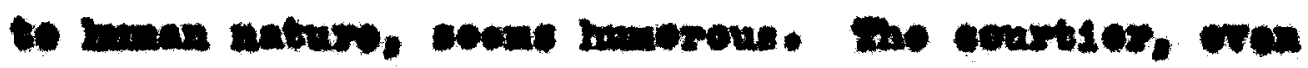

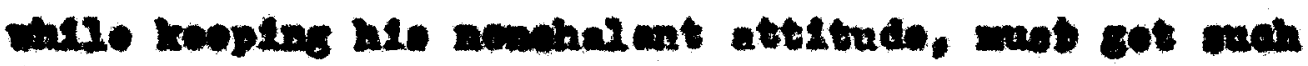

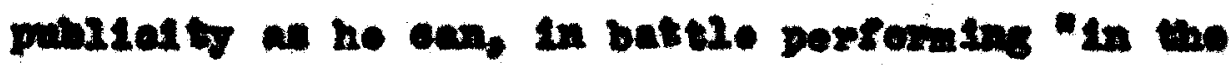
algut of noble wen that be of nont oetimeticn in the

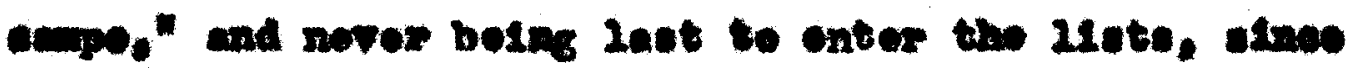

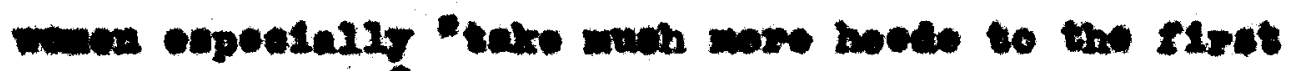

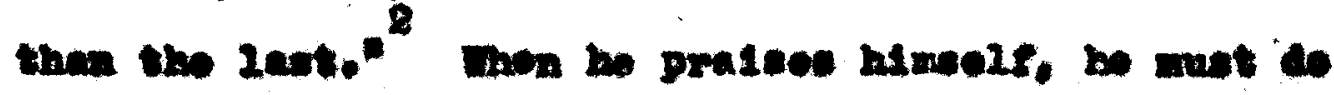

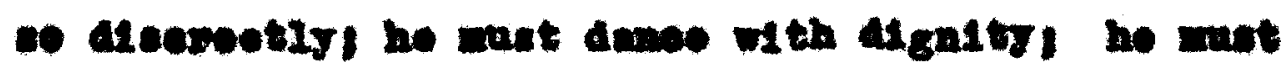

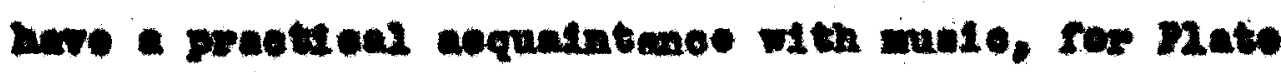

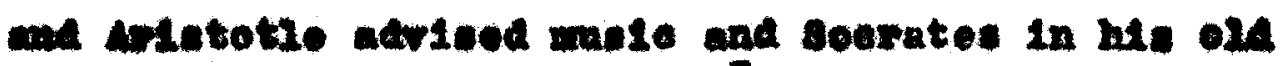

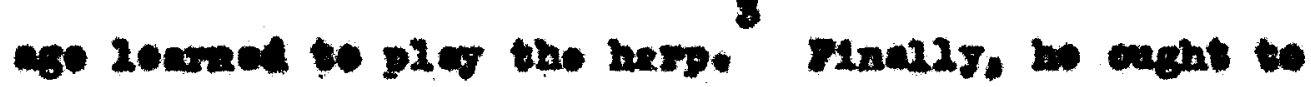

2

gatidice. B. 75.

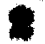
H.t. pe. 08,84. 10. P. 76. 


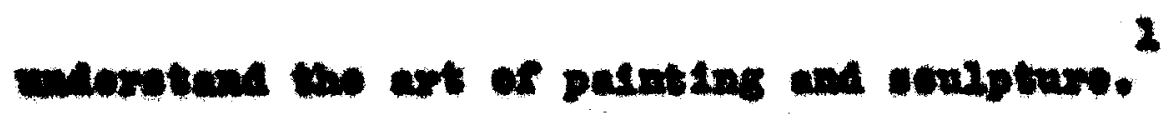
Ing othos procopto aro late dom tor the

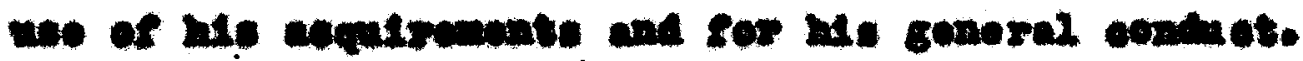

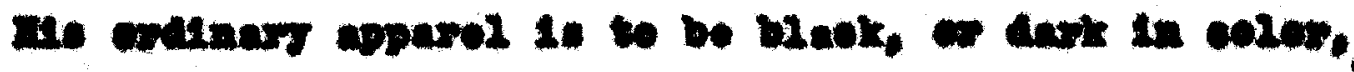

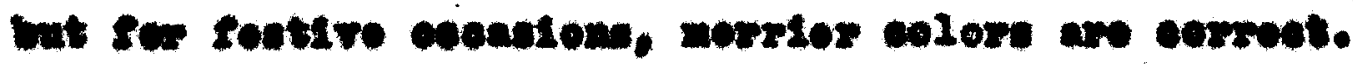

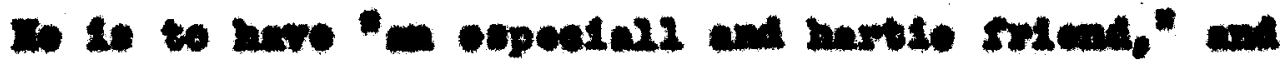

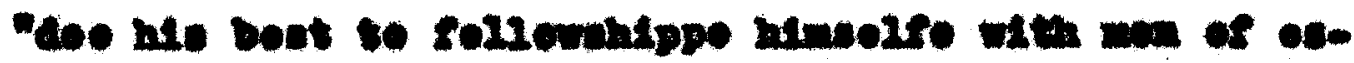

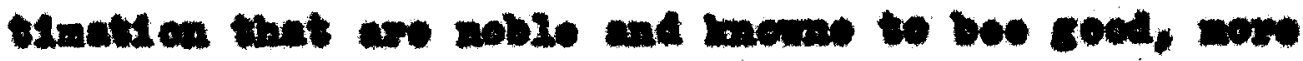

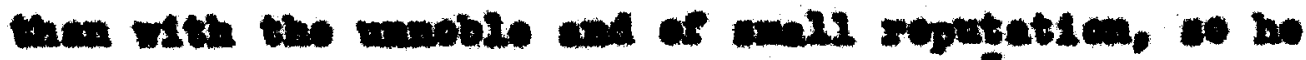
bee aleo boloved we nowoured of them."

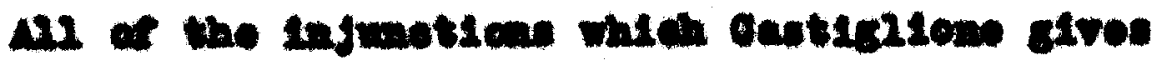
polut to the sane ond - that the convtlor bo proporis

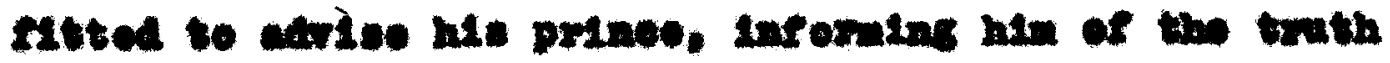

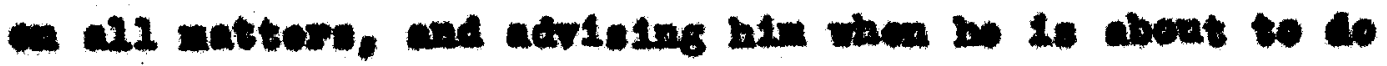

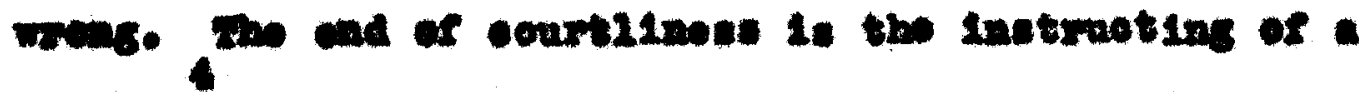

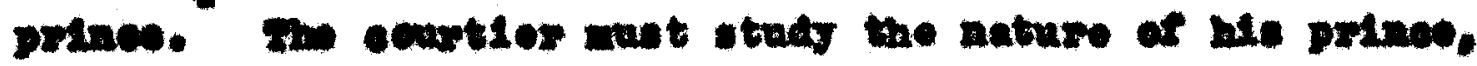

2

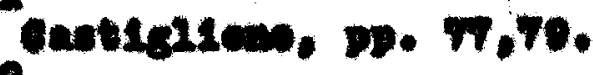
2 Miser p. 217. Deces se. 200. Mane D. 870 . 


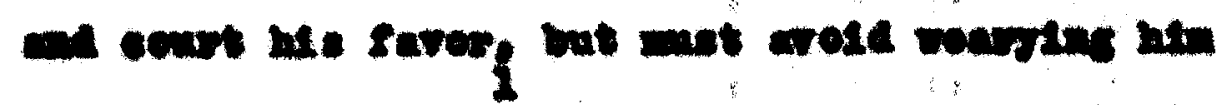

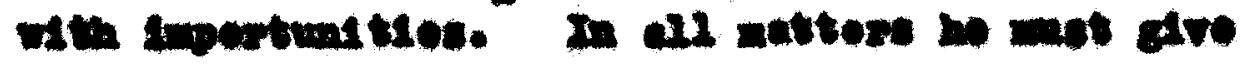

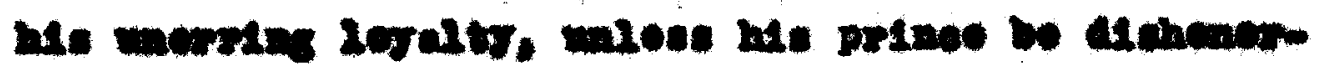

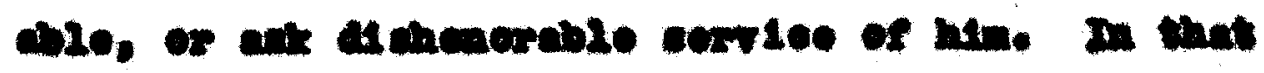

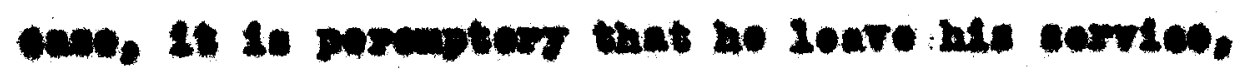

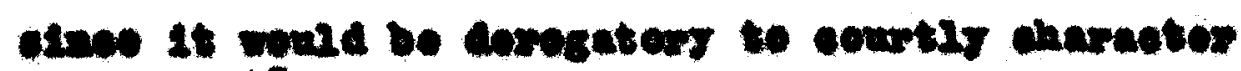
to renente

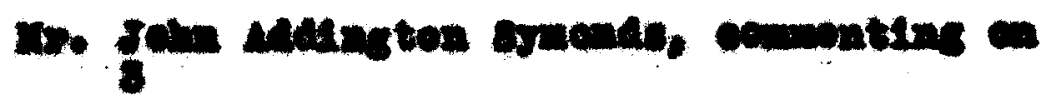

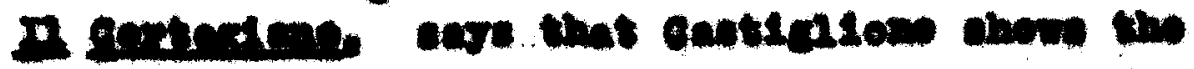

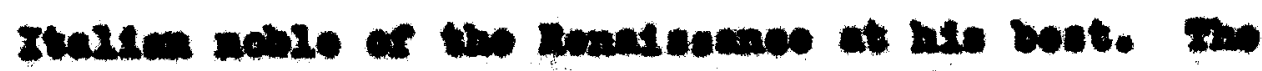

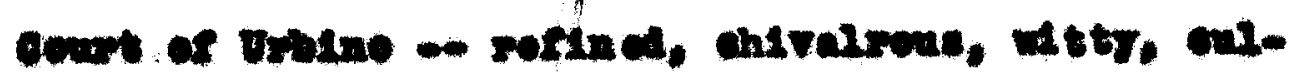

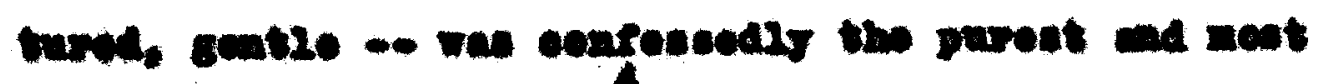

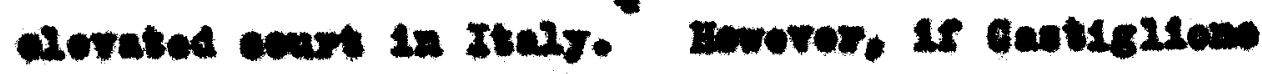

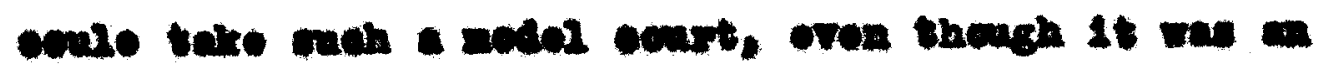
oreoptem. and dre its manore and onture to the

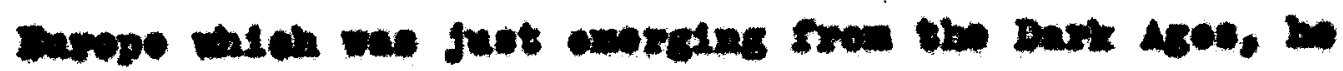

1

antextens. pp. 204-100.

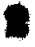

719.. p. 212.

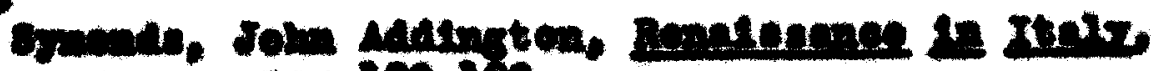
4 Dip: $203,26$.

In. D. 204. 


$$
-\infty
$$

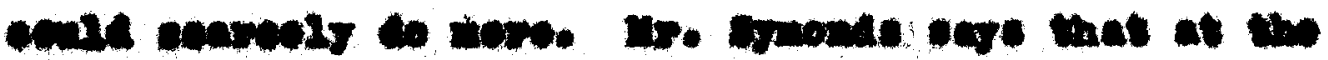

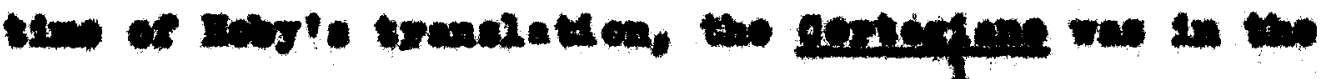
head of al the gatherouk of mappo.

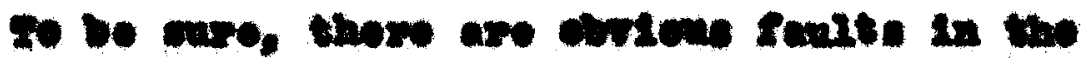

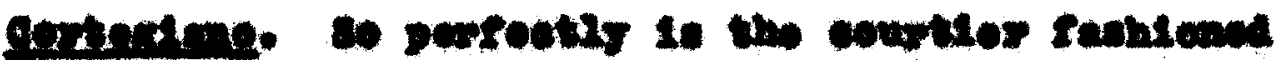

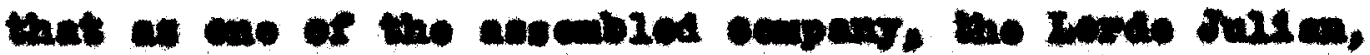

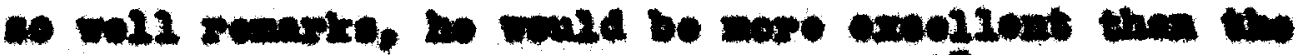

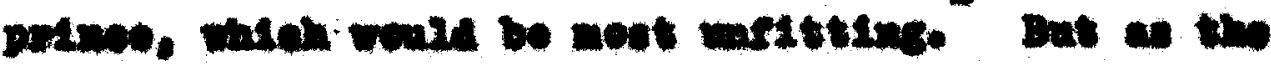

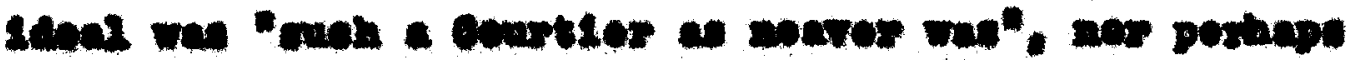

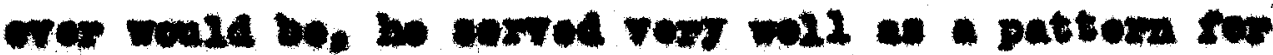

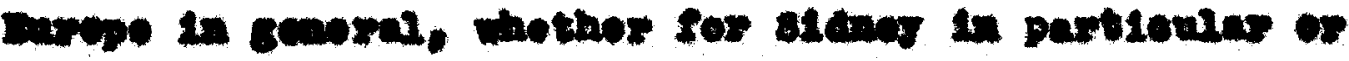
nots.

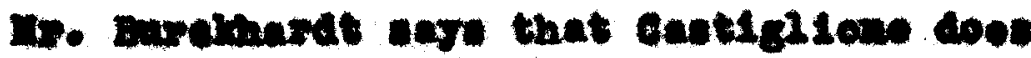

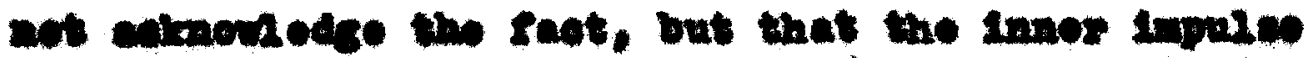

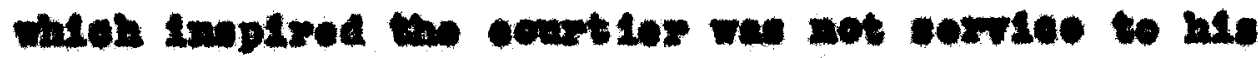

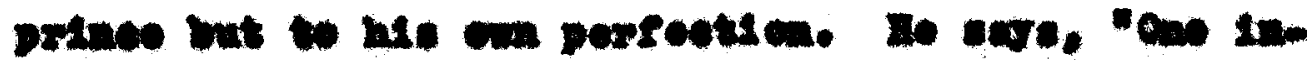

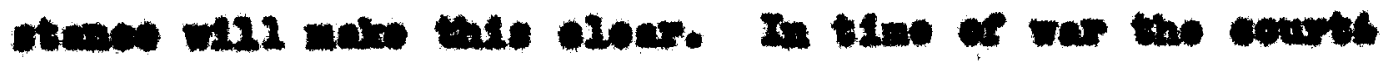

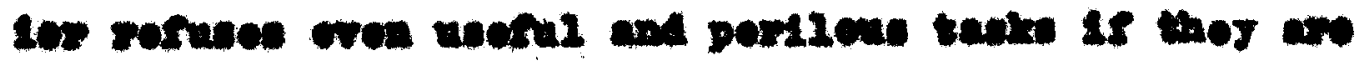

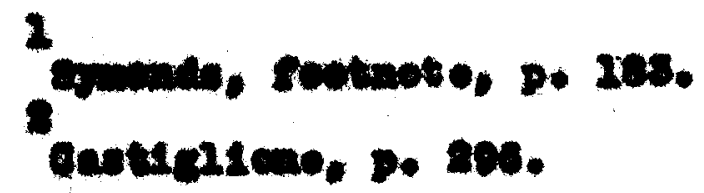




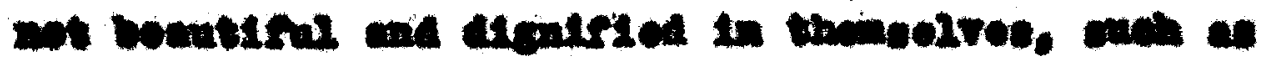

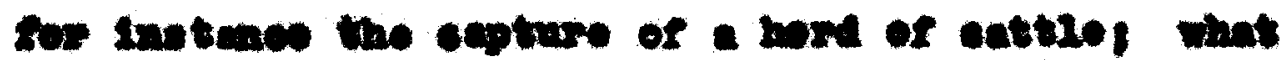

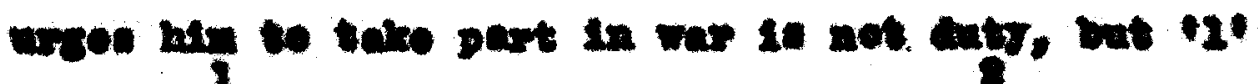

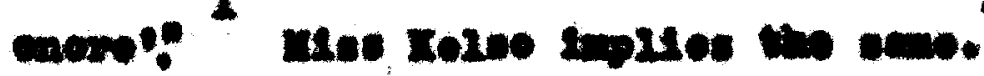

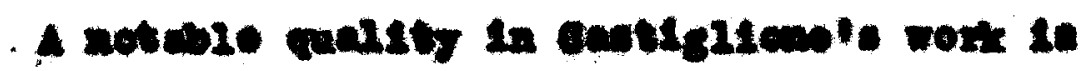

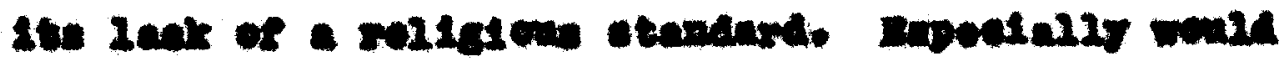

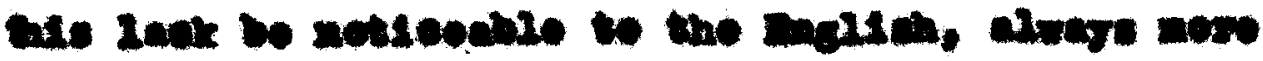

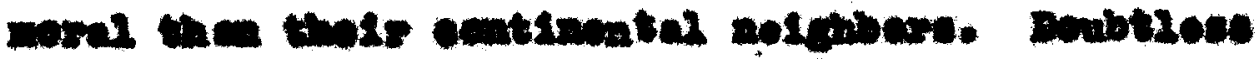

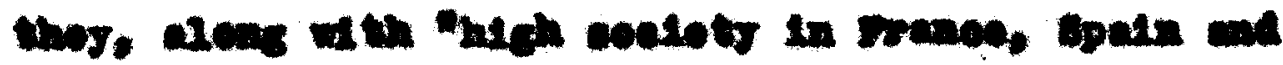

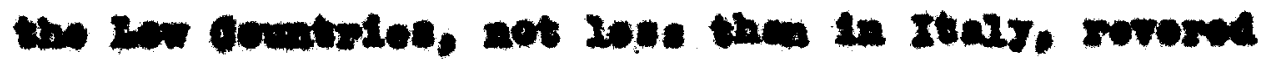

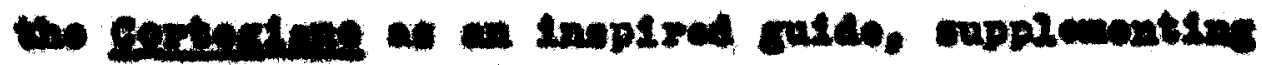

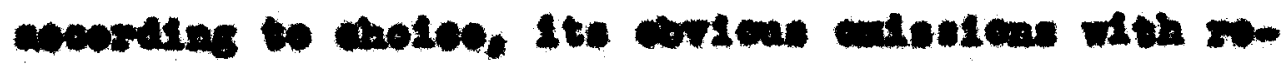

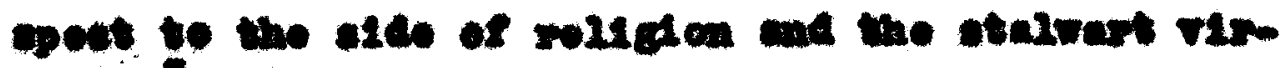
tomes.

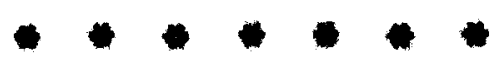

Dow. wat wowe the akferemese botren the

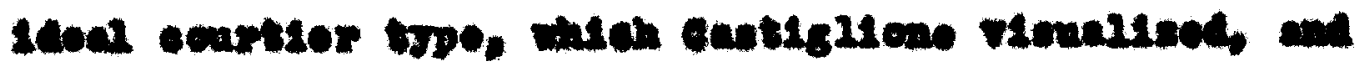

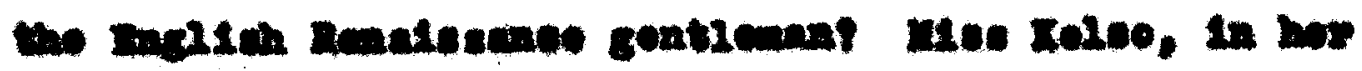

2 Emaricuard, p. 200 . 8 Intee, po as. $\boldsymbol{8}$

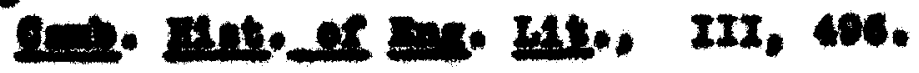




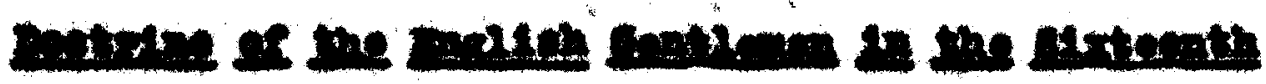

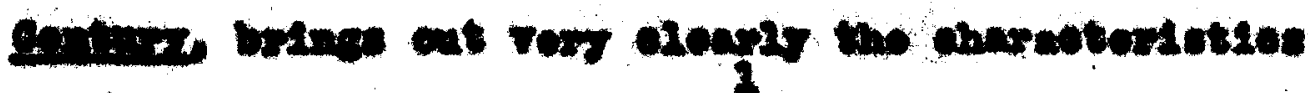

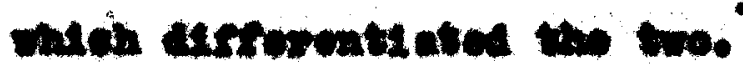

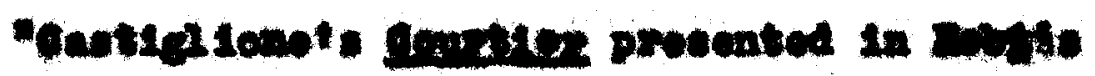

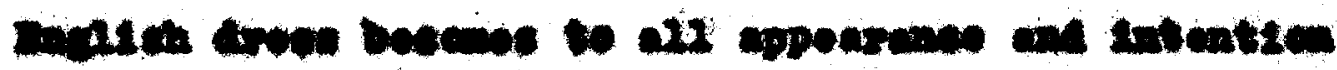

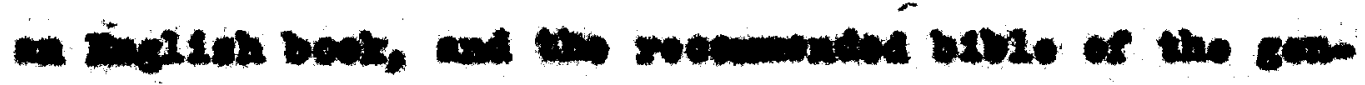

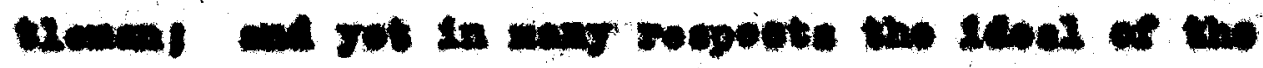

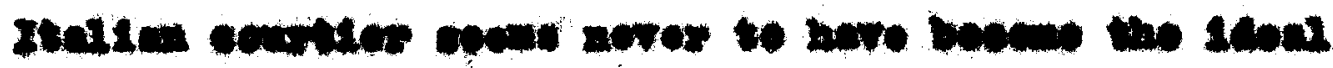

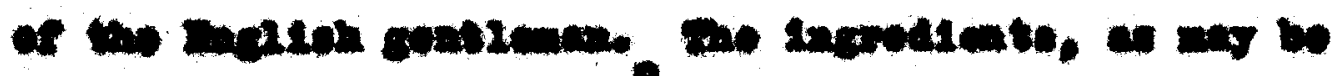

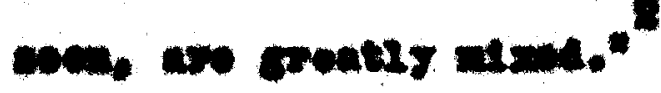

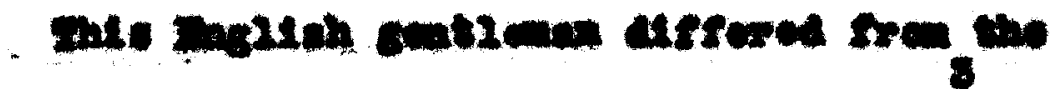

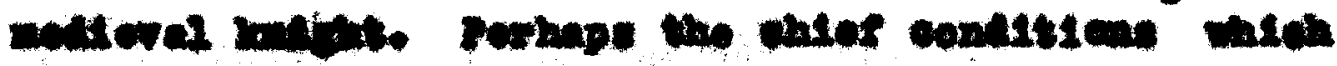

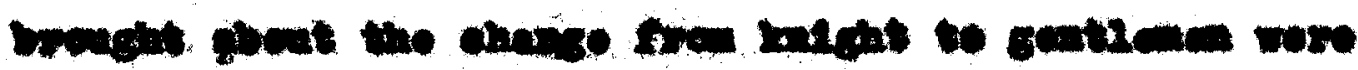

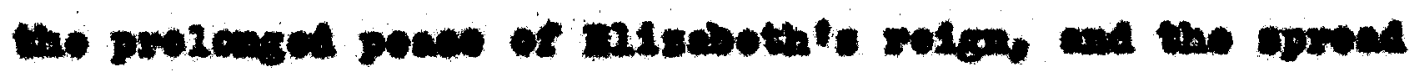

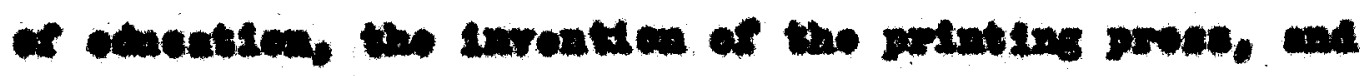

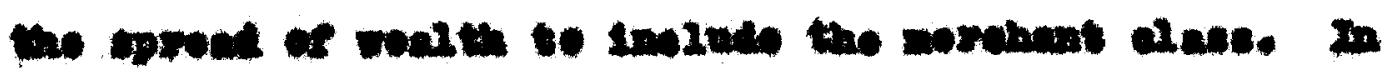

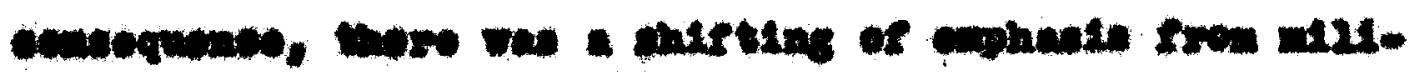

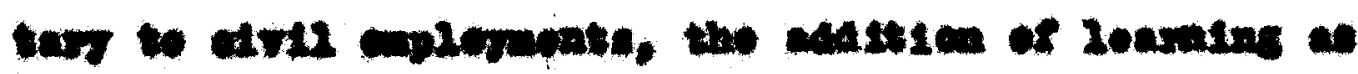

2

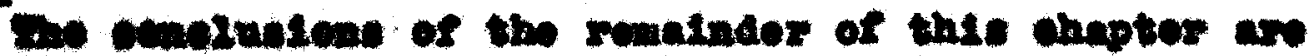

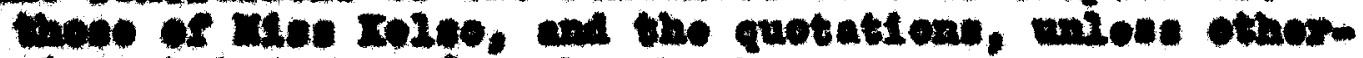

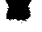
tao steted, aro frem bor book.

D. 28.

8

ne. 24,28. 


$$
-8
$$

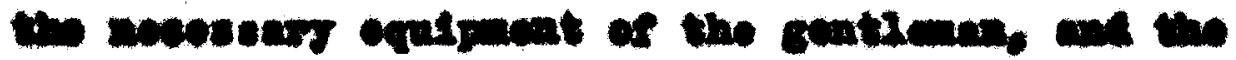

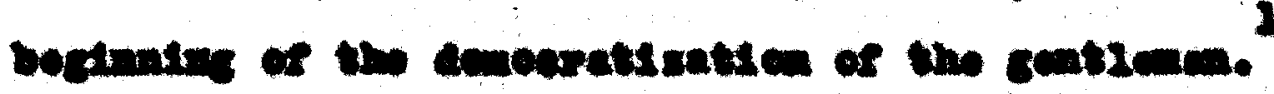

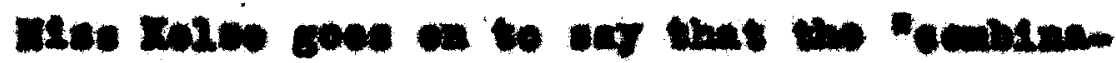

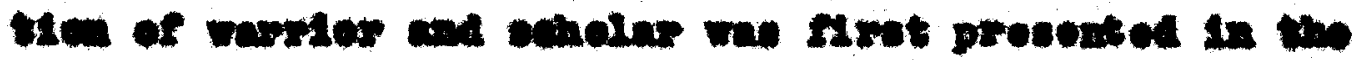

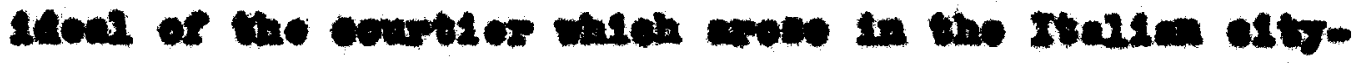

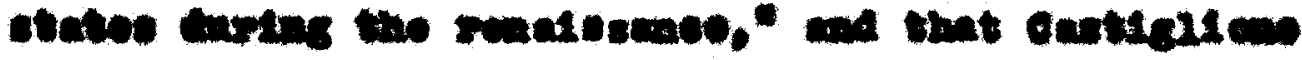

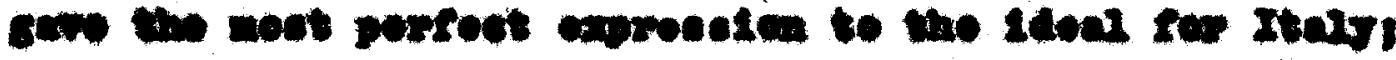

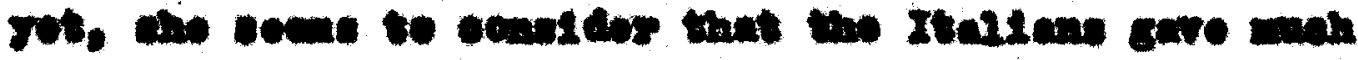

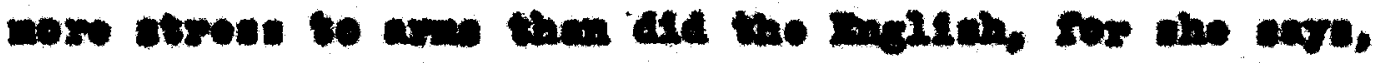

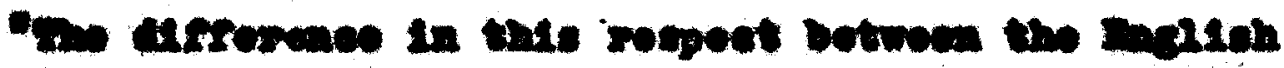

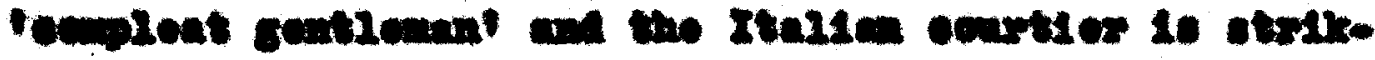

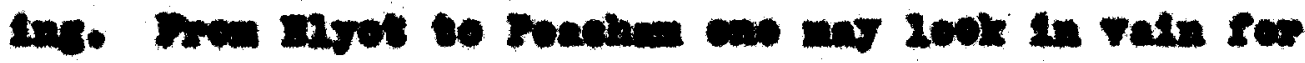

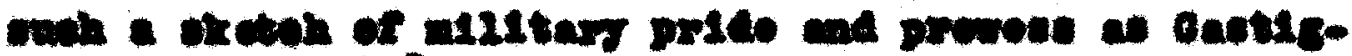
Lem proecente o"

Pownes ates of all the alfrawnese botwen

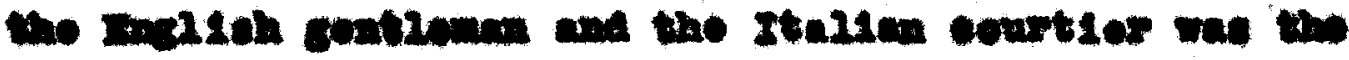

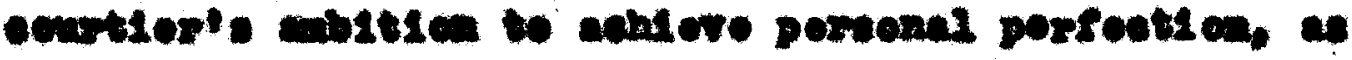

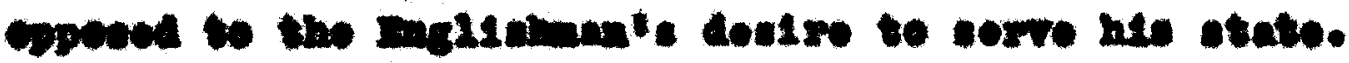

2

2. 27.

D. 4. 


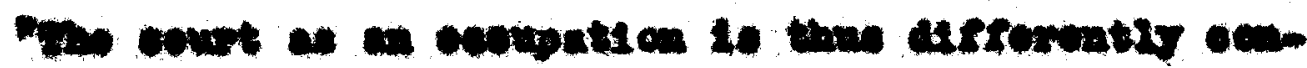

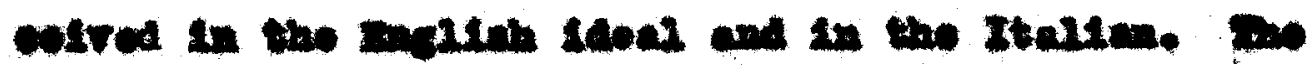

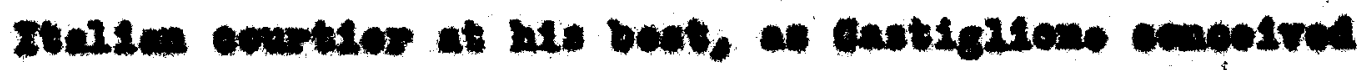

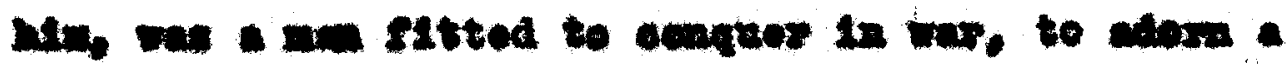

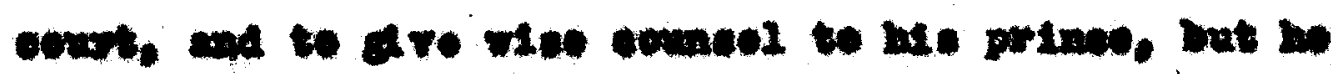

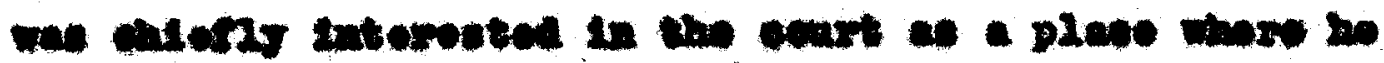

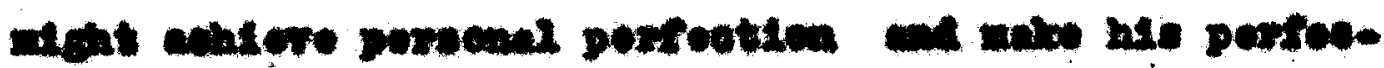

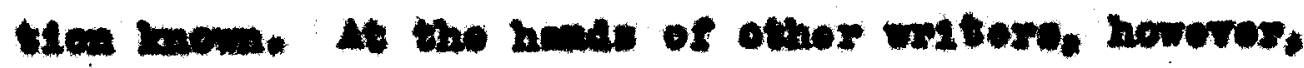

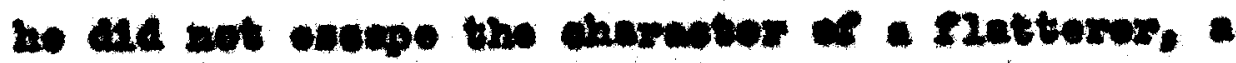

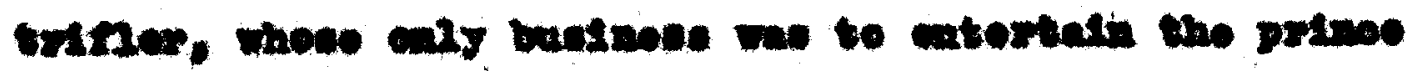

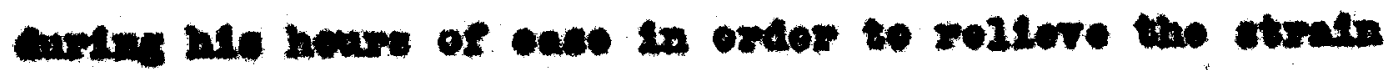

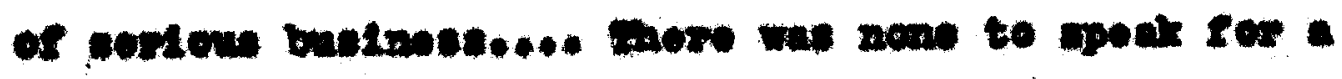

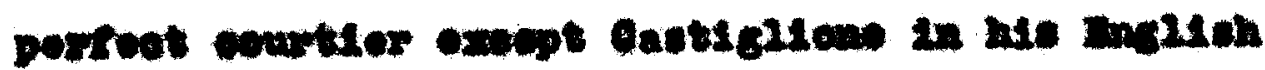

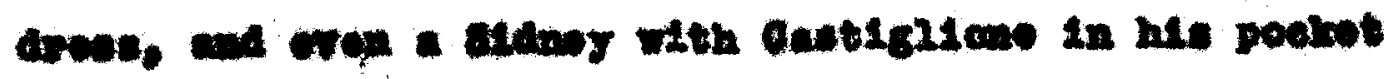

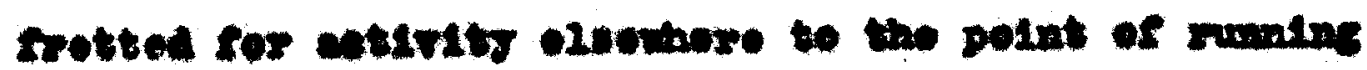

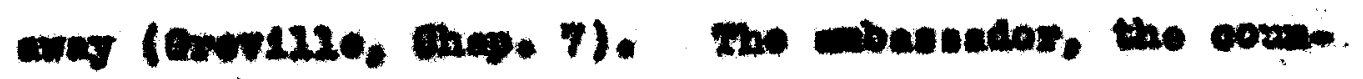

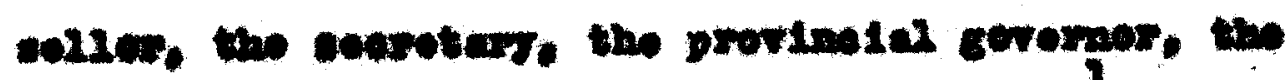

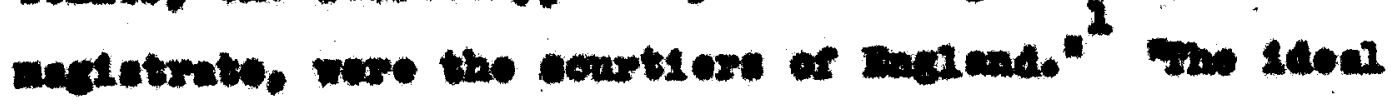

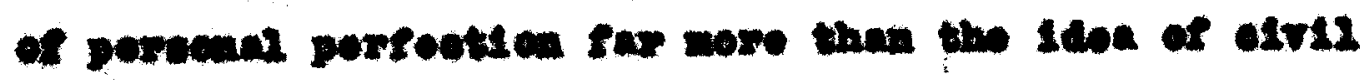

2

D. 4x-18. 


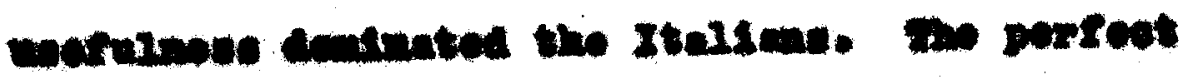

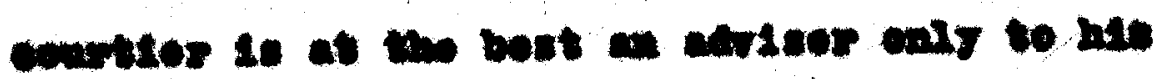

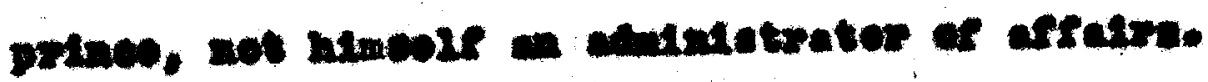

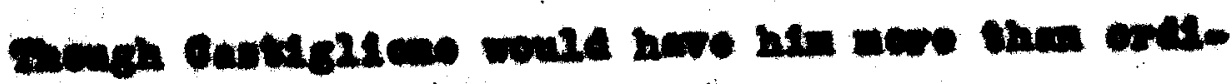

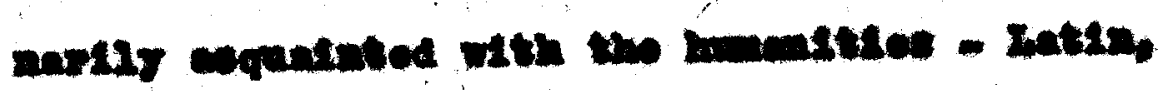

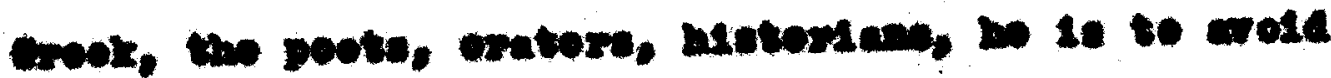

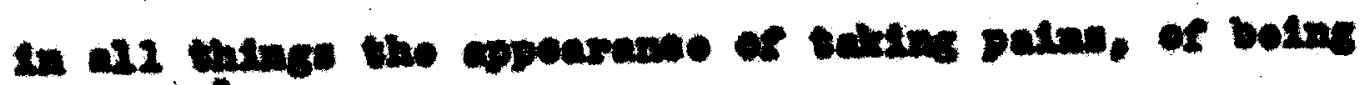
$\operatorname{cosec}^{2}$

to graver and not the watinese of 216

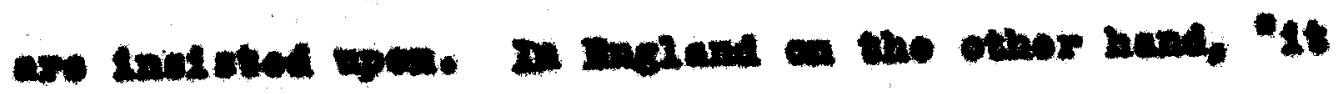

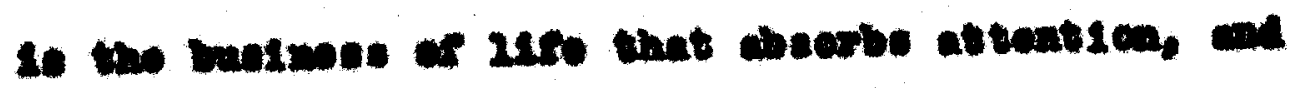

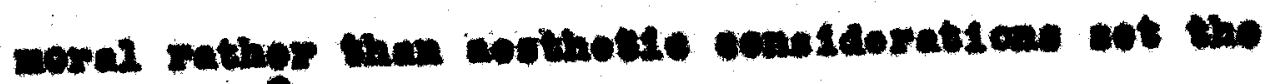
crancasen

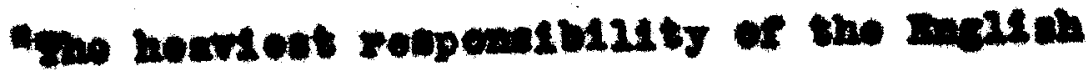

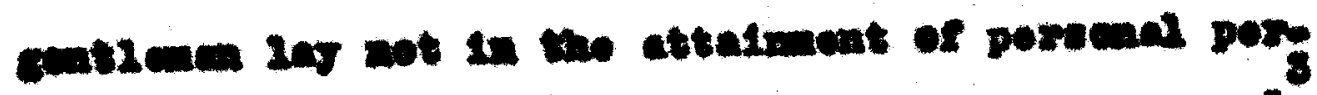

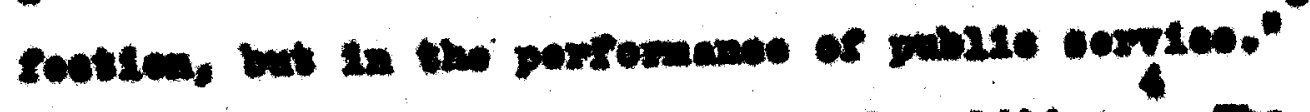

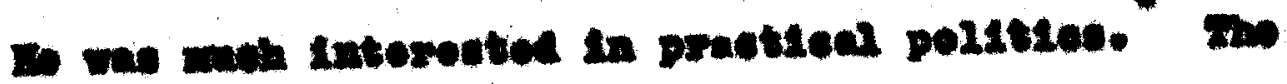

2 D. exwas. pp. Auns. 4.20. p. 80. 


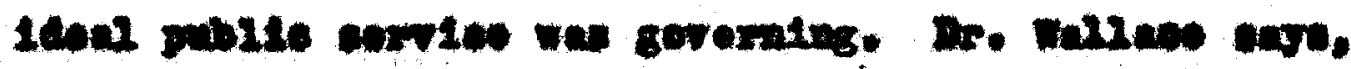

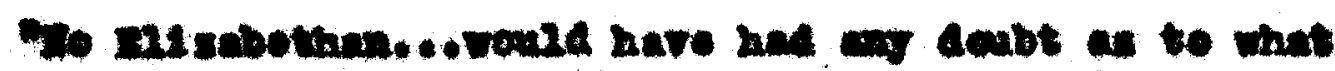

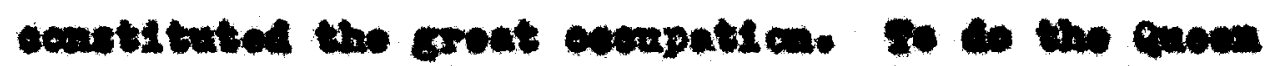

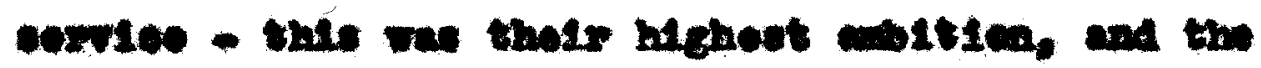

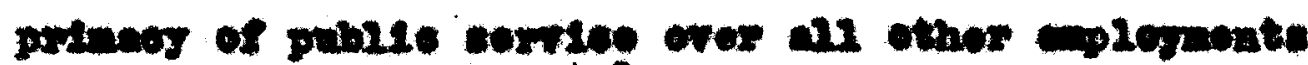

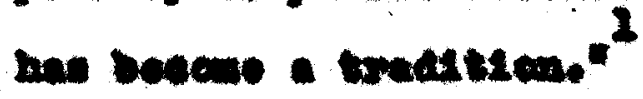

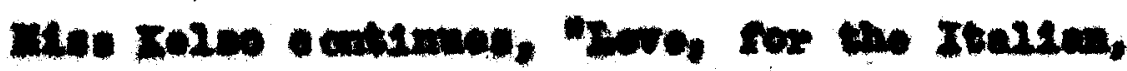

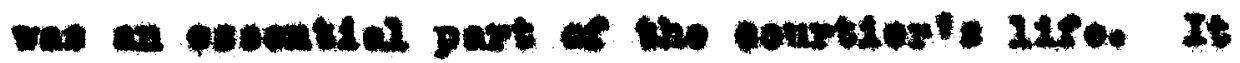

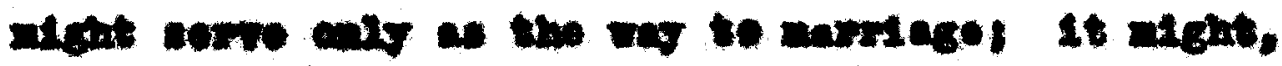

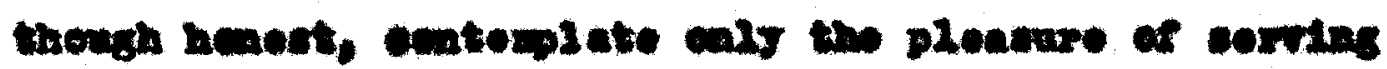

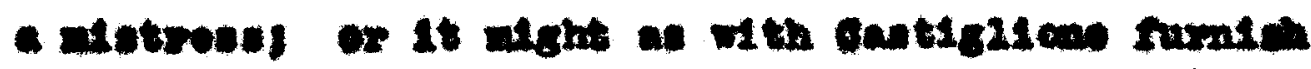

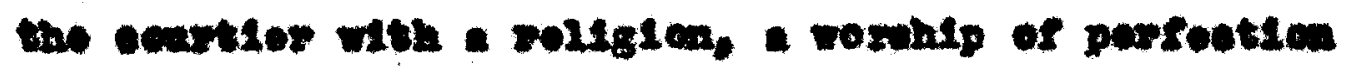
ontule hinear.

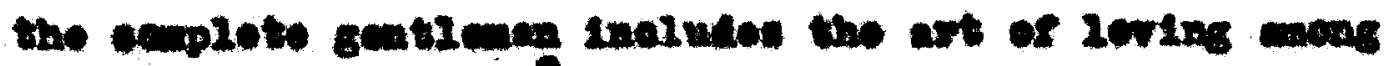
bis escoplestumente"

Hovals wow anelt upen of the angles as the

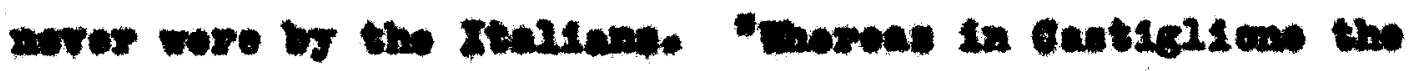

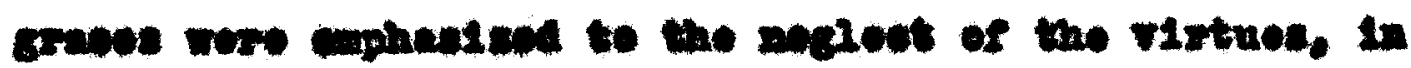

2

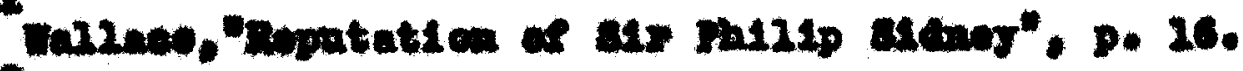
8 noleo. p. 08. 


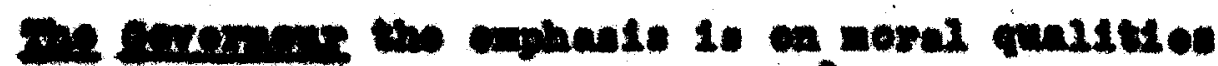

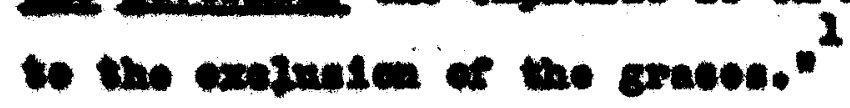

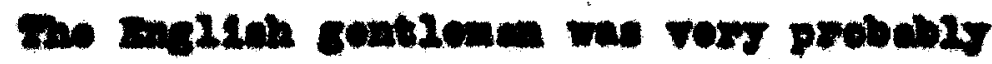

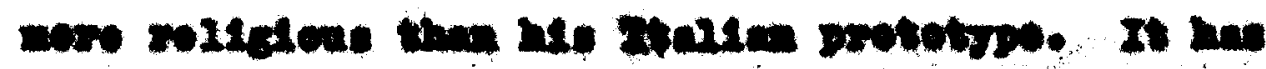

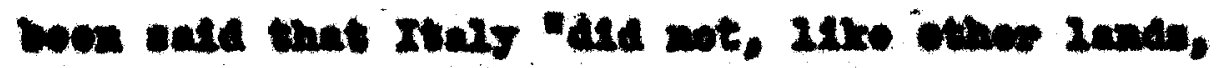

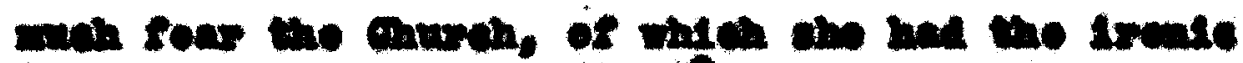

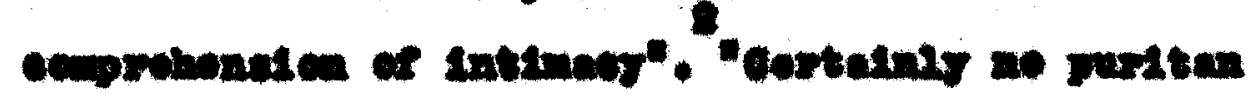

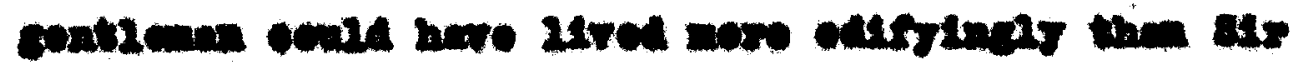

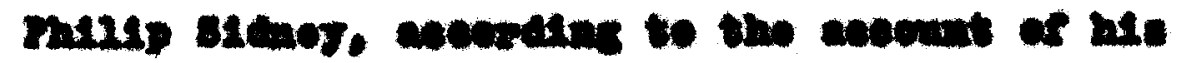

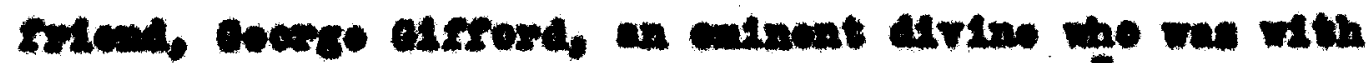

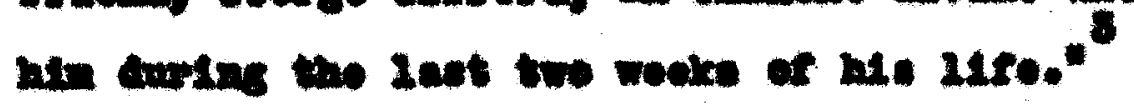

phose wos waxs other precepts for the

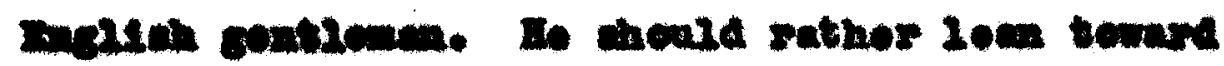

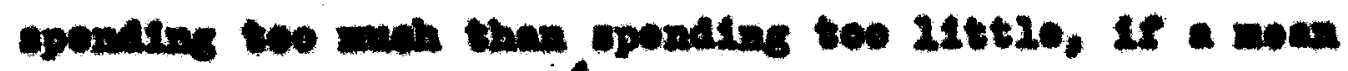

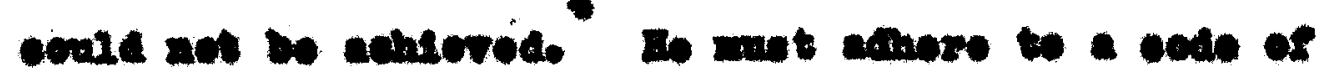

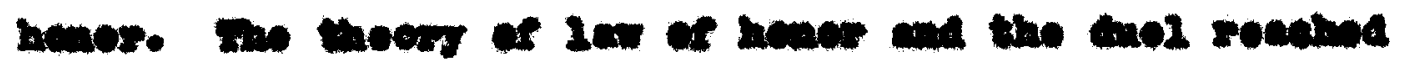

2

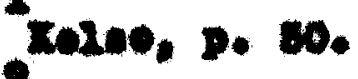

-

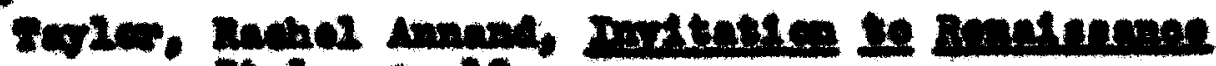

8 Xitr. 20.

1.2. 107.

D. 10. 


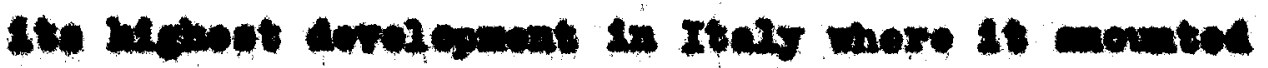

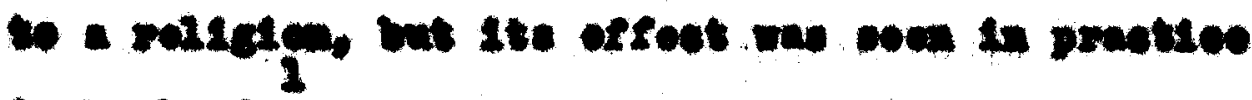
in molend.

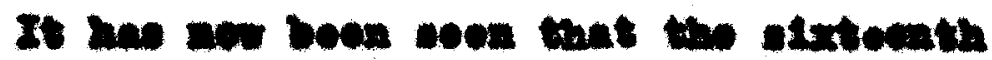

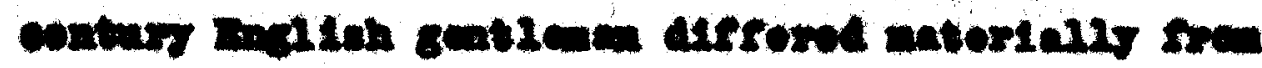

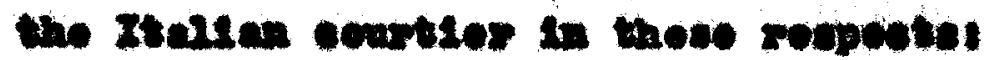

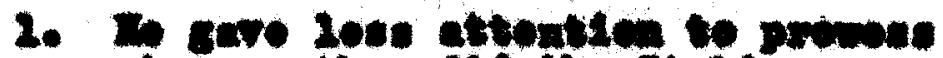

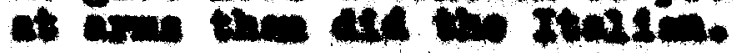

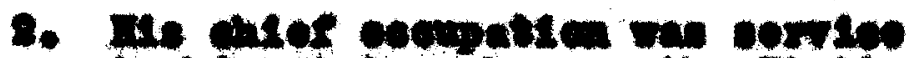
to his otate, fwooes the Itaren'.

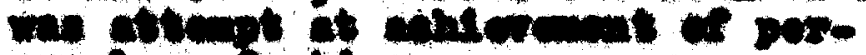
conar portoitica.

5. The at of lovice was not no of

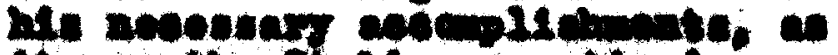
It vas the Iterle ecurterts.

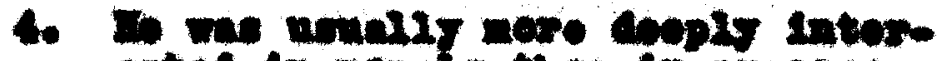
onted in merale the in cracos: tortilin, Ite zone.

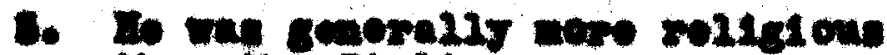
man the Itallen.

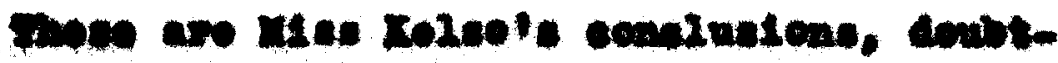

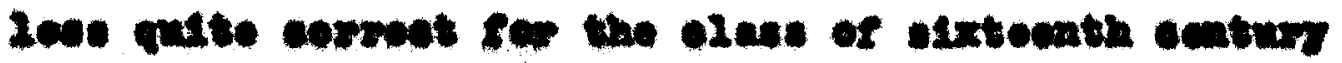

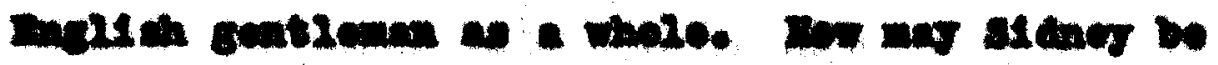

2 5. 204. 


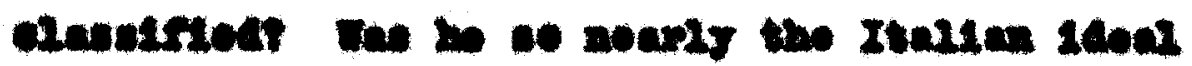

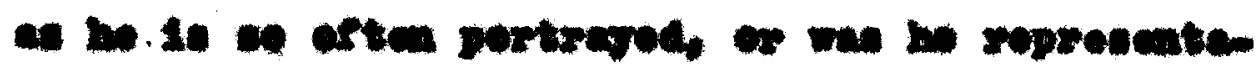

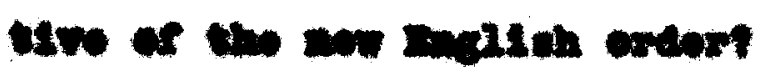


aria $x$

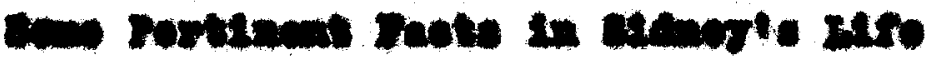




\section{arvirat $x$

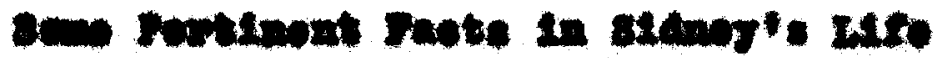

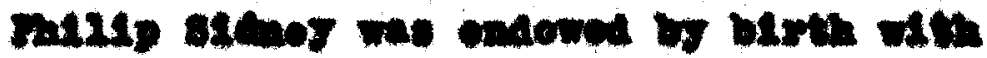

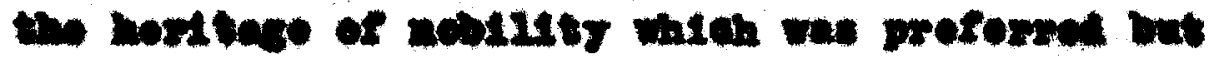

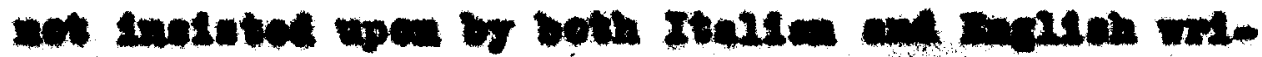

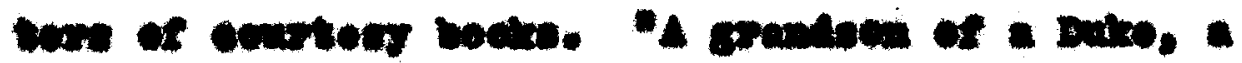

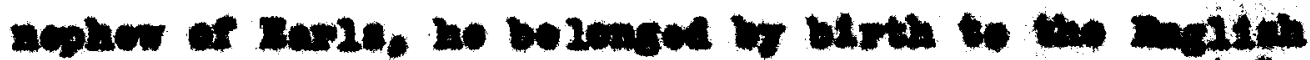

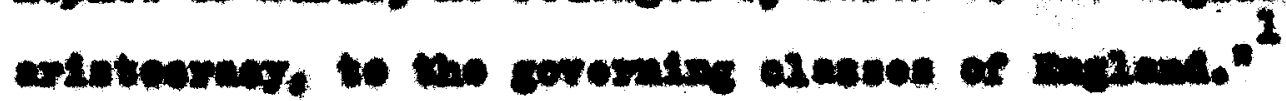

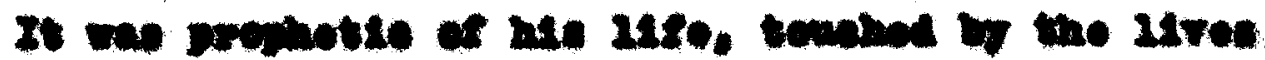

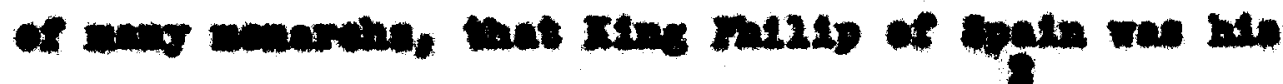

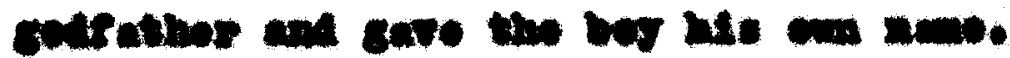

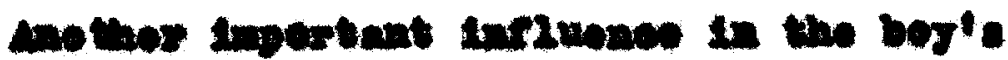

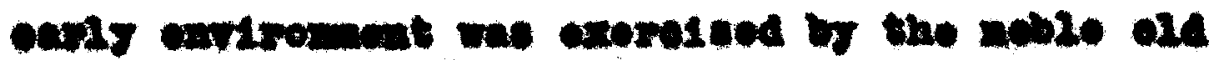

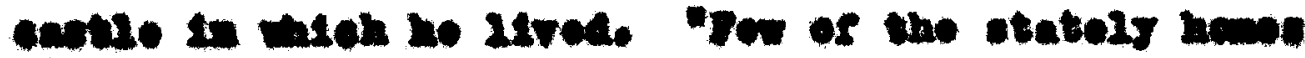

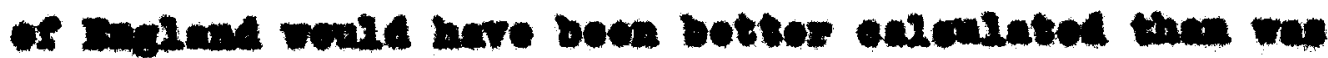

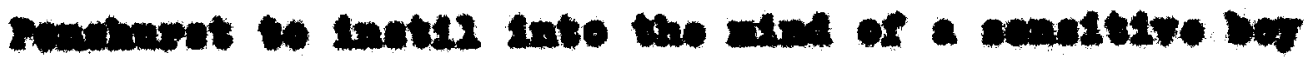

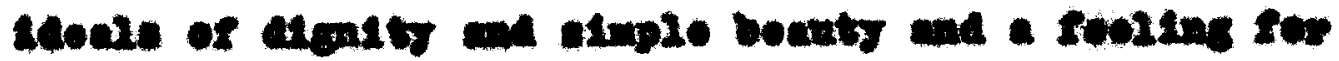

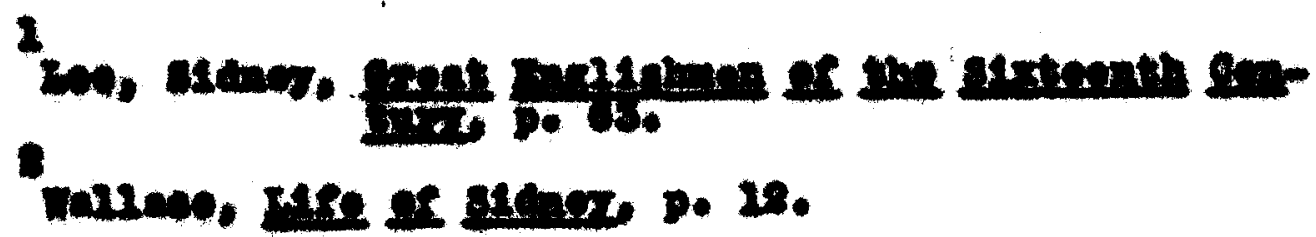


moterse*.

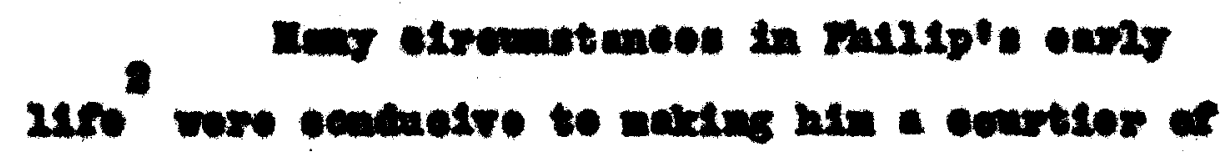

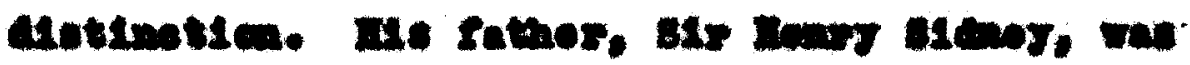

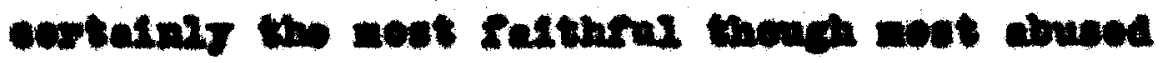

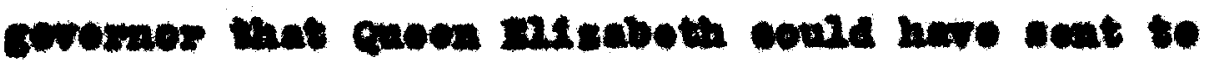

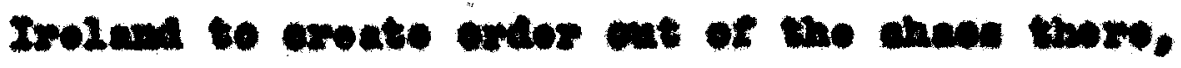

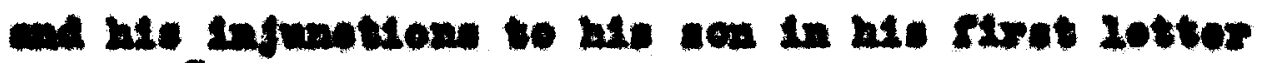
8

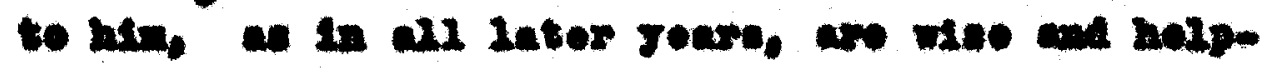

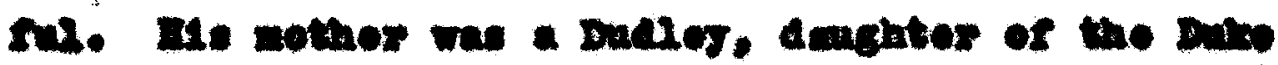

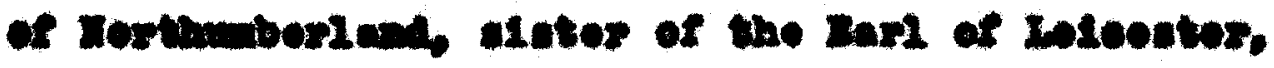

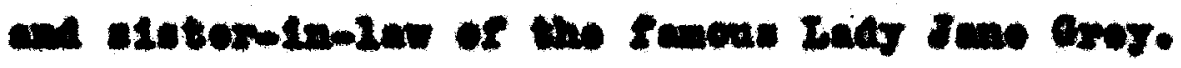

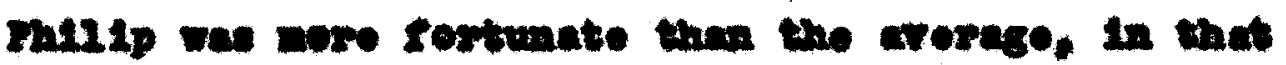

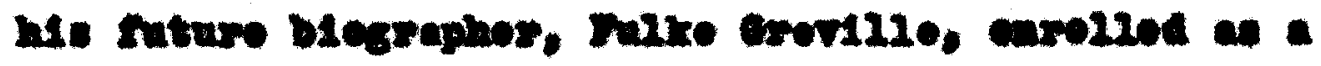

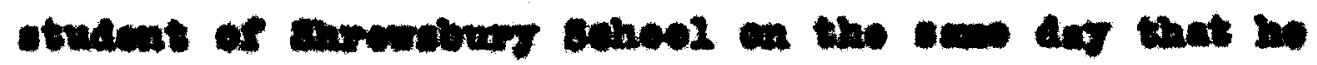

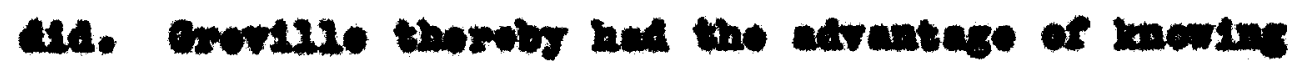

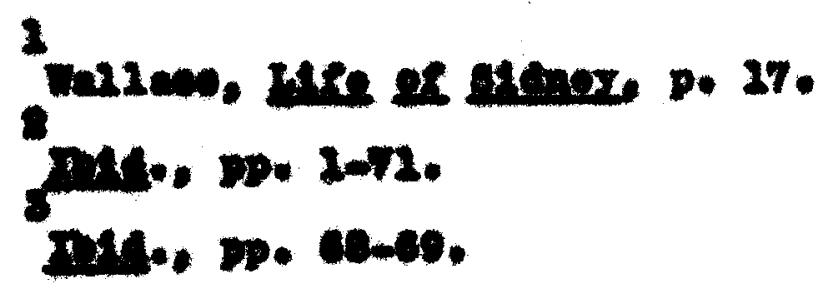


mulle for a groat partlen of the 2abtosle 2180.

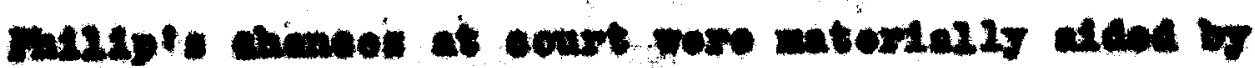

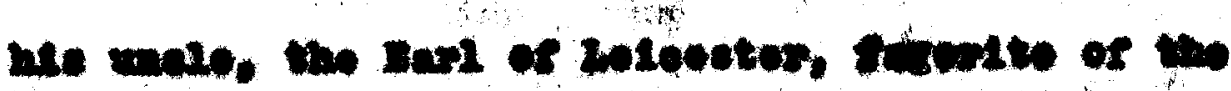

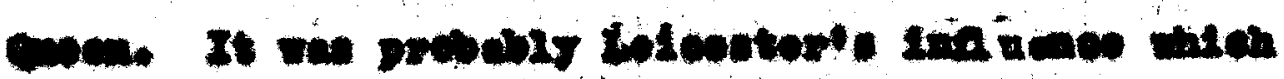

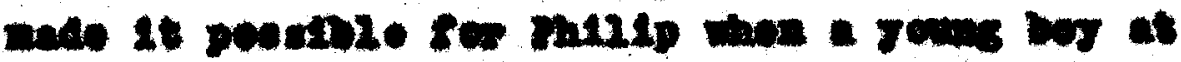

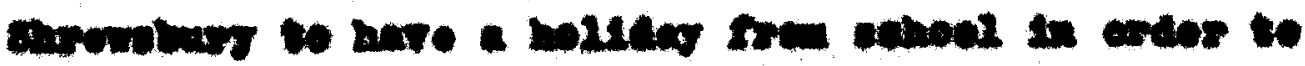

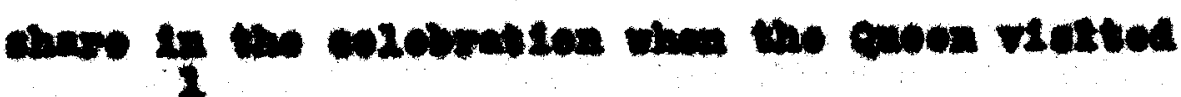
ancent.

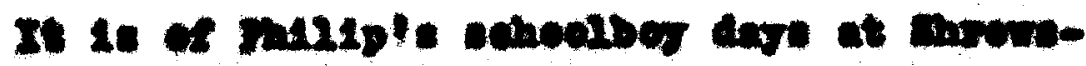

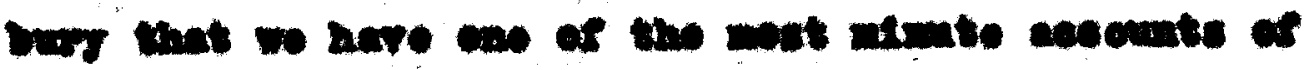

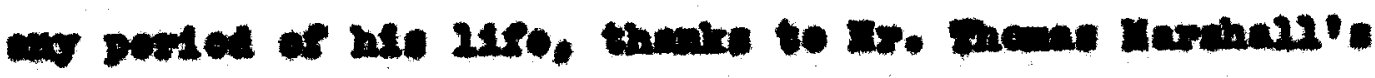

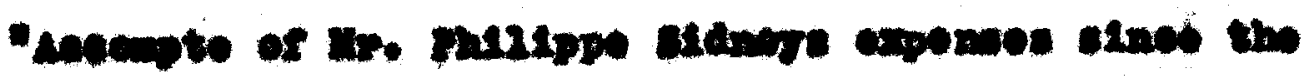

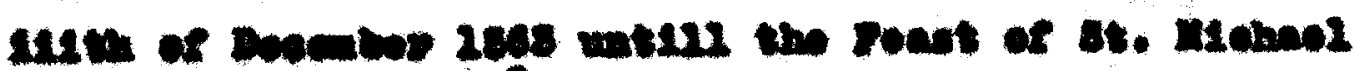

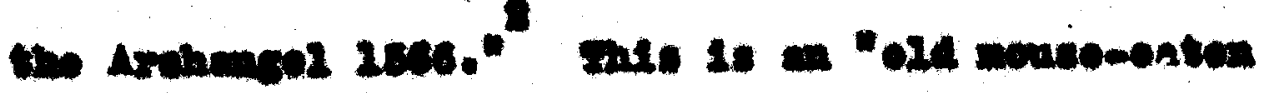

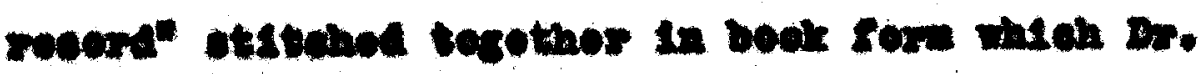

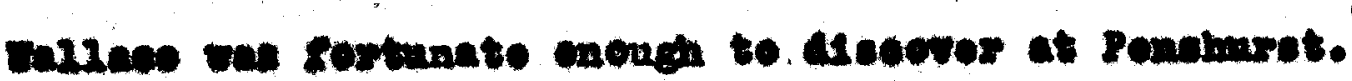

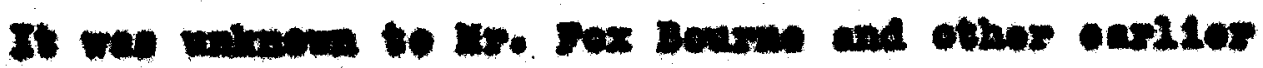

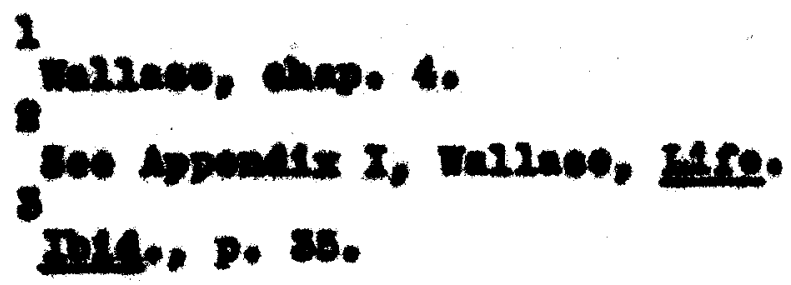




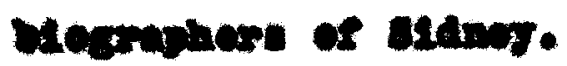

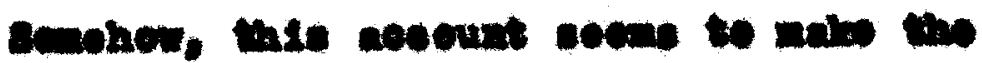

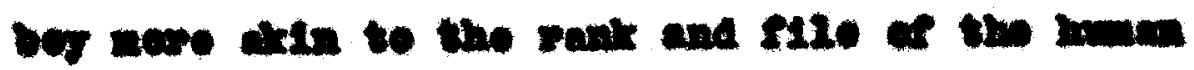

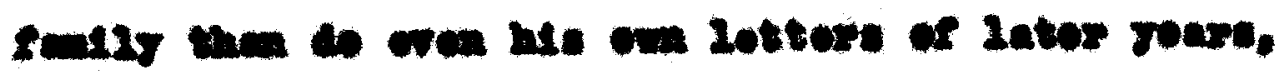

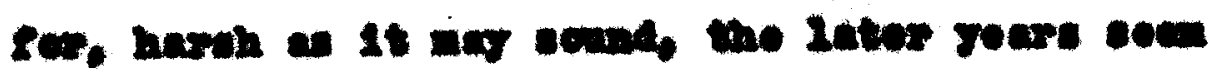

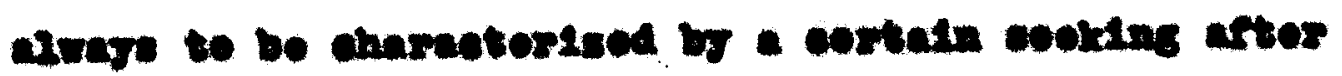

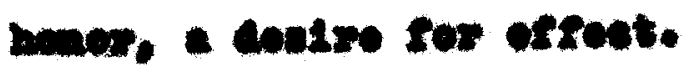

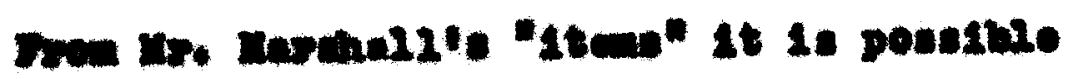

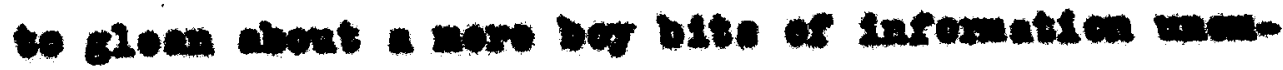

beoes with the comotery of superiative prateo

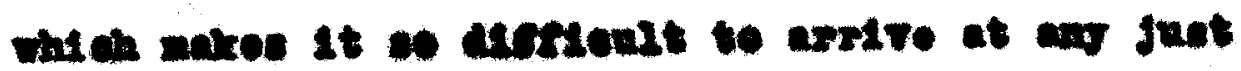

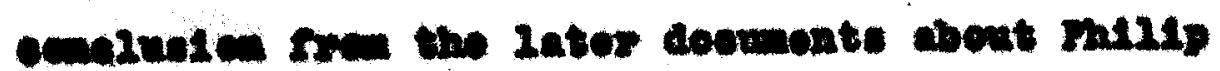

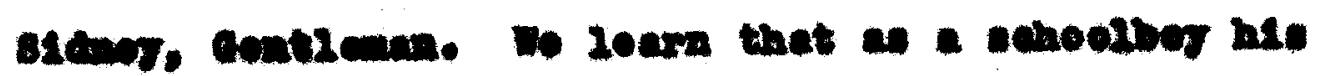

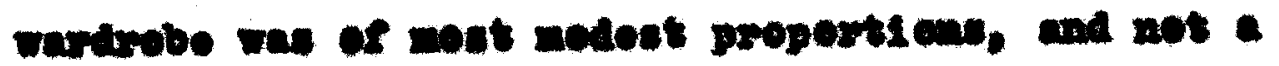

enall part of Me exponese wore oreasted to the parm

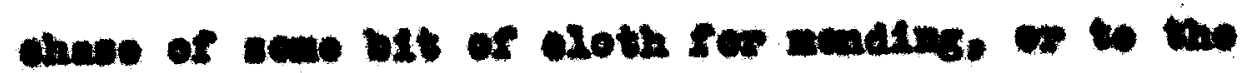

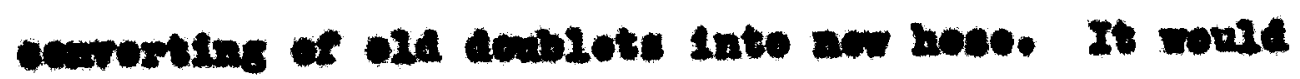

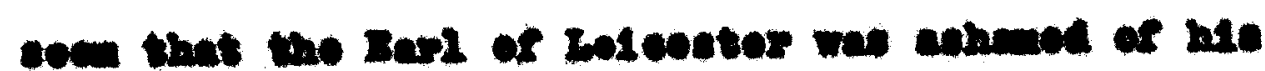

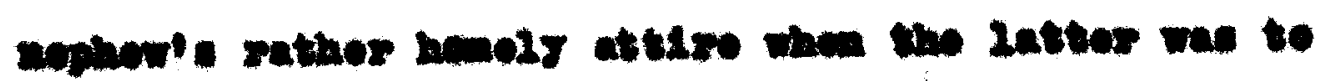

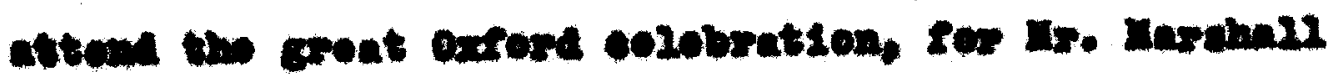




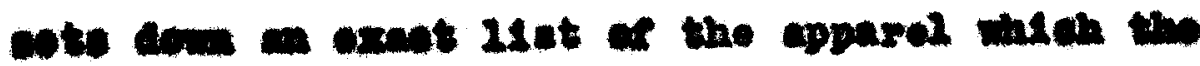

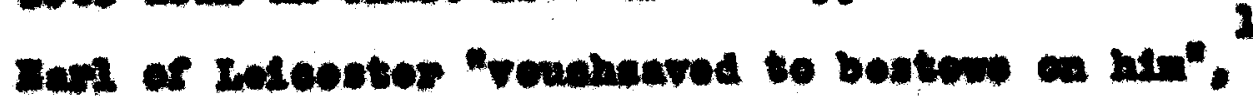

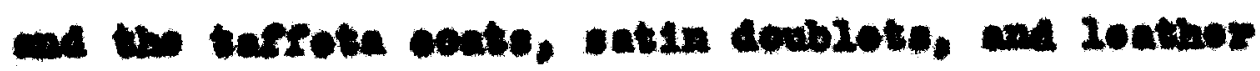

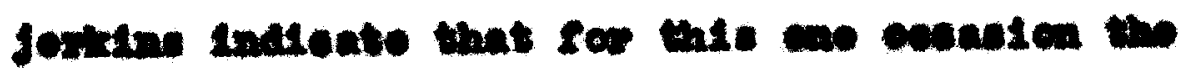

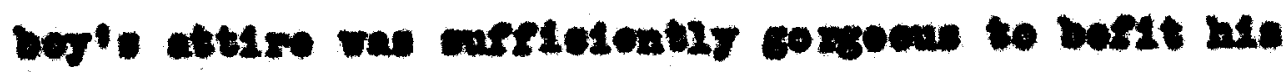
station.

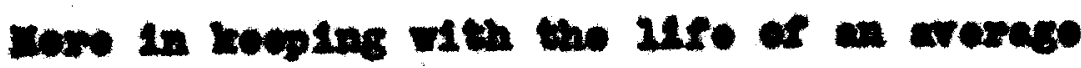

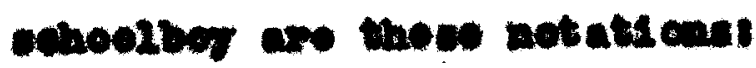

"It ser a yesto of elothe to make r. Filippe a palso of boote hose

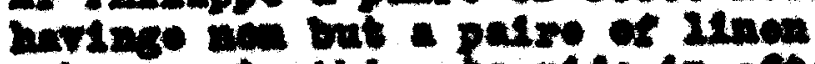

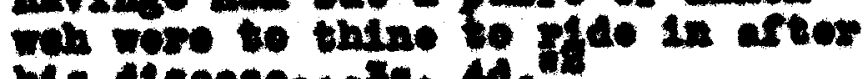

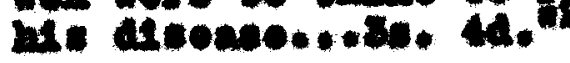

"Ita tar cortalno b (ma U)estes" cos to ohowto at byrds......8ds

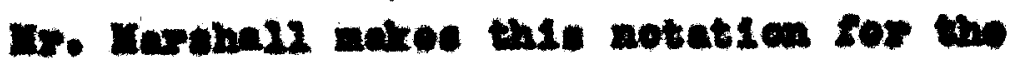
noturn typ tren extost:

Ite gorouma of Ix mi2ippo

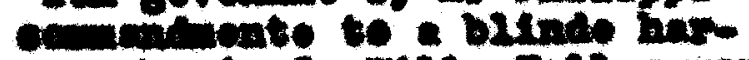

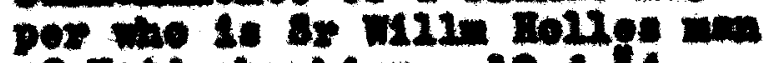

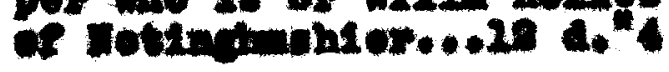

2

appenalex I, p. cor.

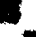

Mile. D. 107.

Mine. 50.400.

Des. p. 42. 


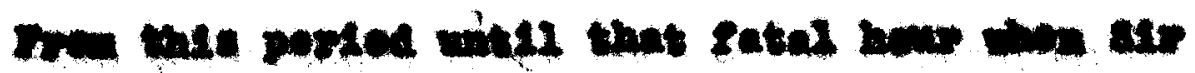

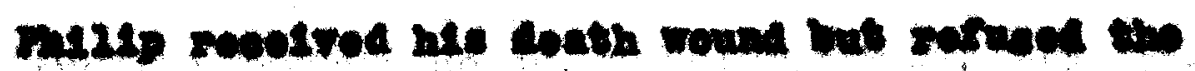

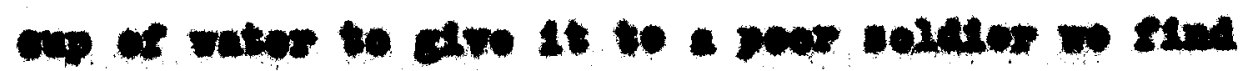

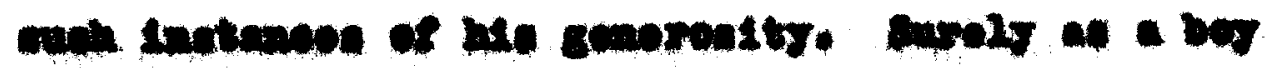

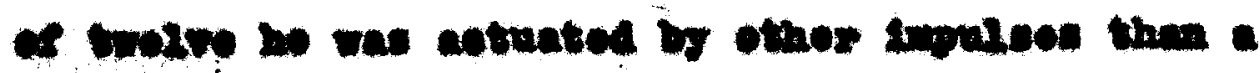

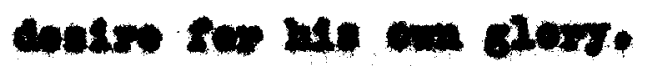

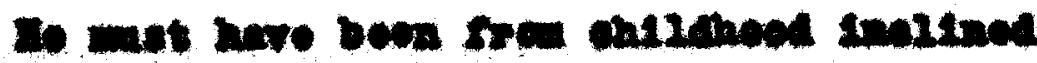

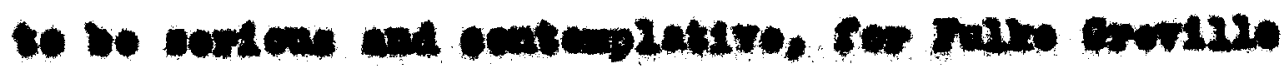
enters.

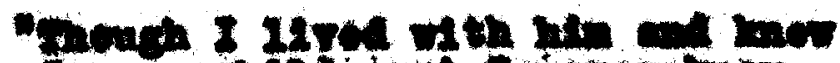

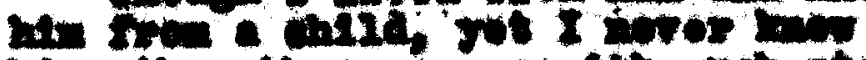

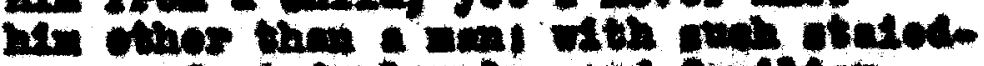

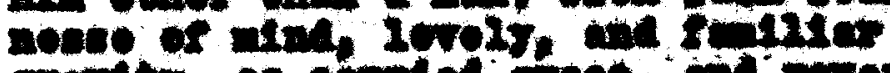

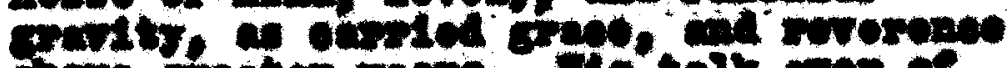

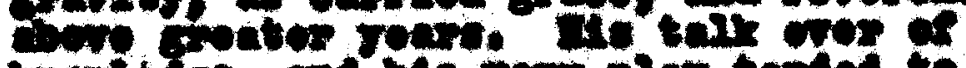

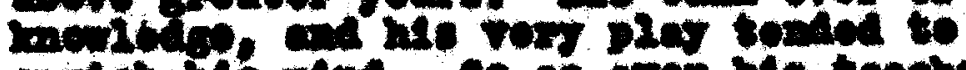

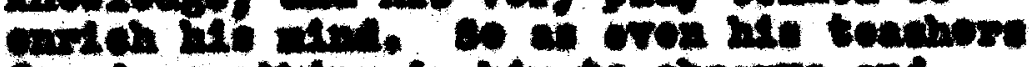

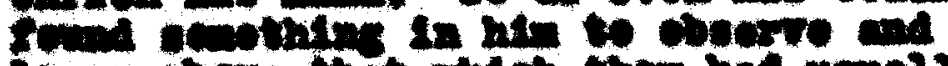

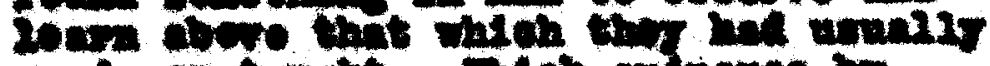

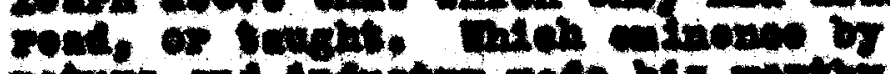

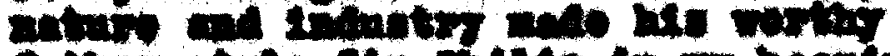

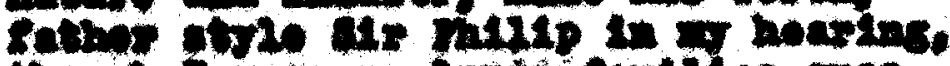

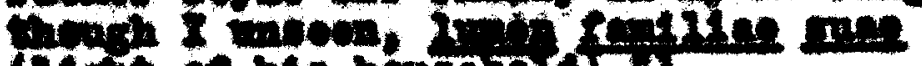

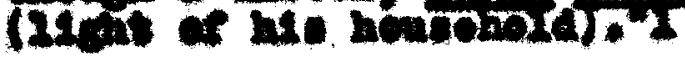

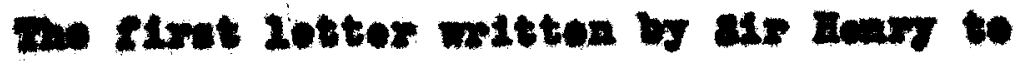

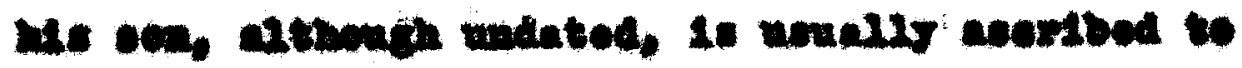

2

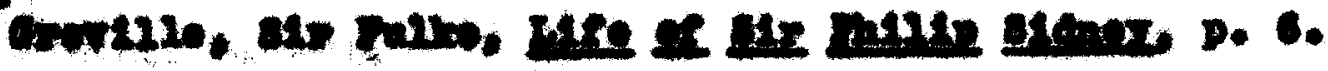




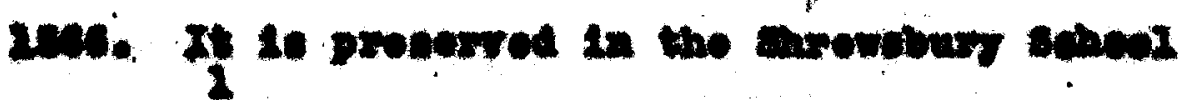
thenge. an is it is a rats anple of ats

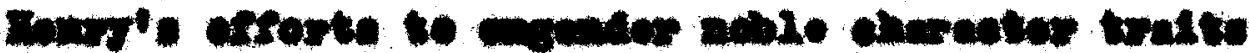

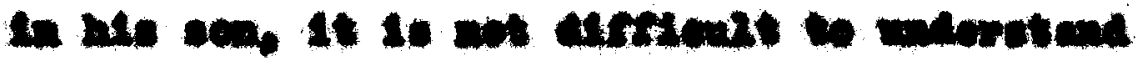

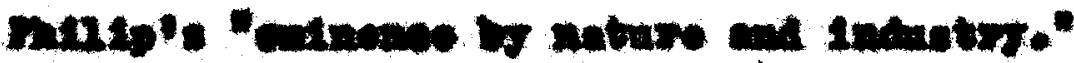

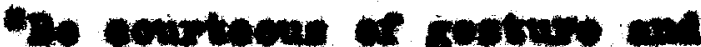

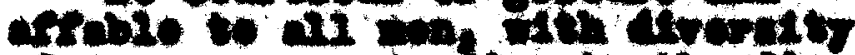

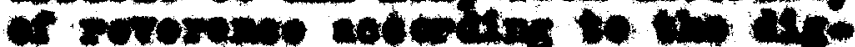

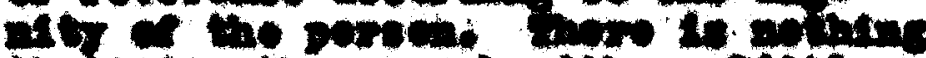

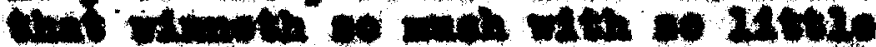
colt n.

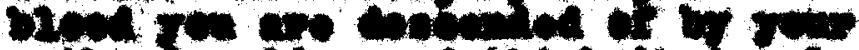

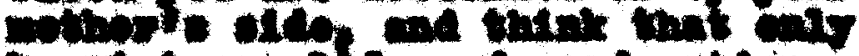

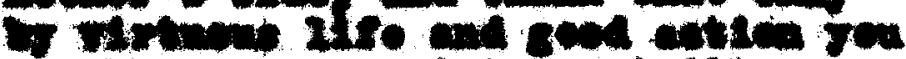

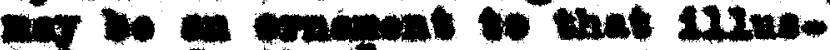
neso sintir.

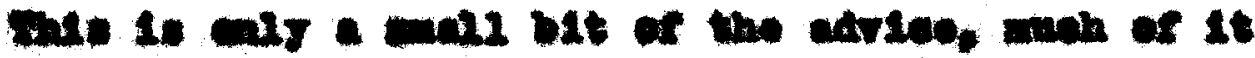

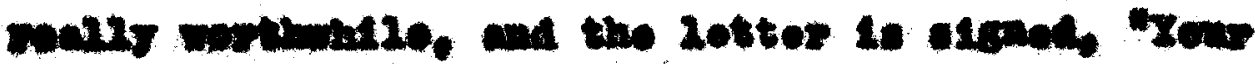

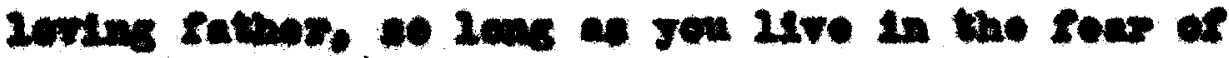

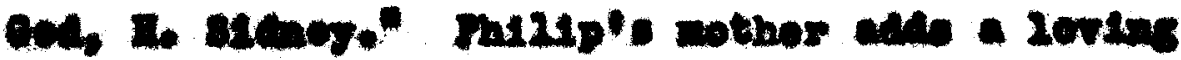

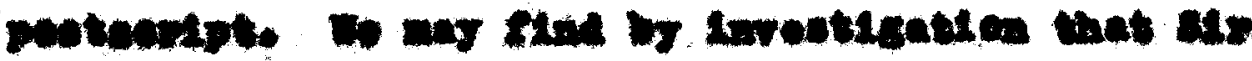

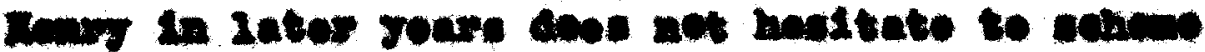

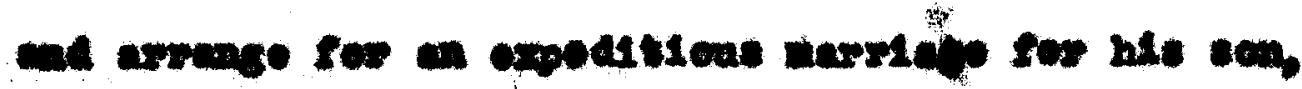

3

ene nulens, ppo cropo. 


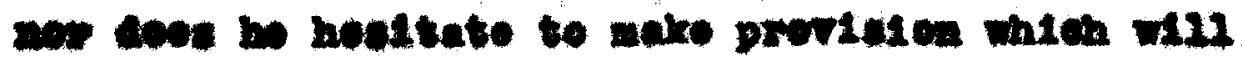

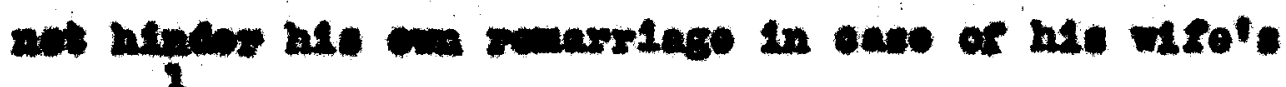

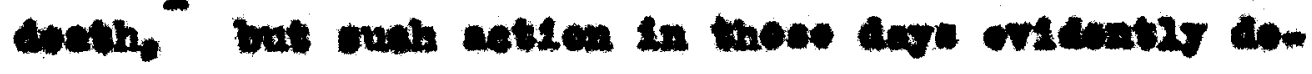

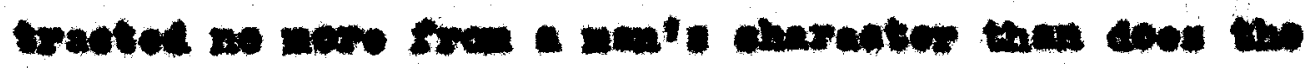

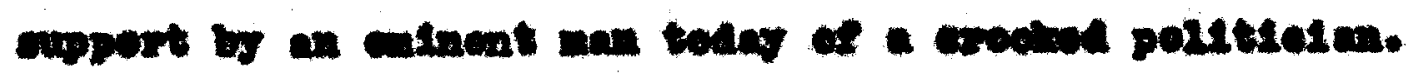

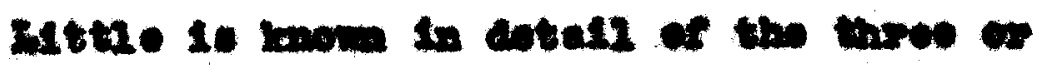

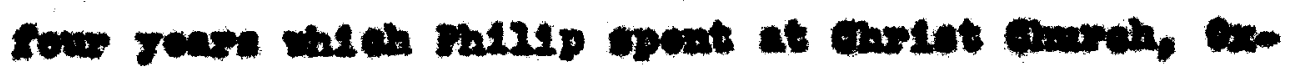

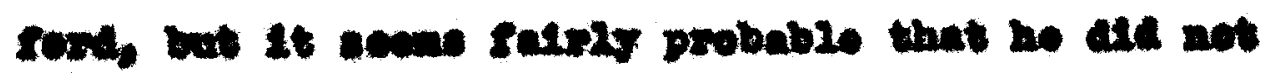
vape he the, wh the townow of his rathor in

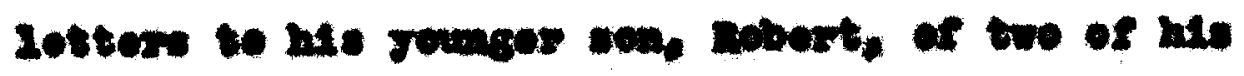

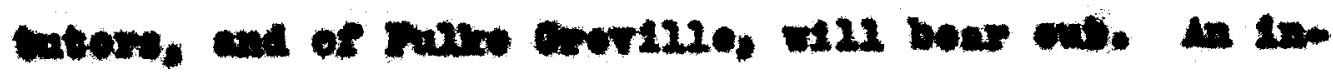

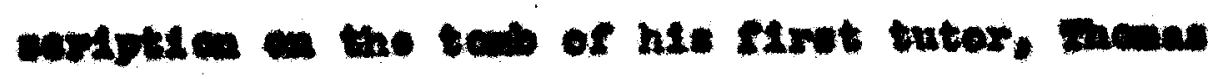

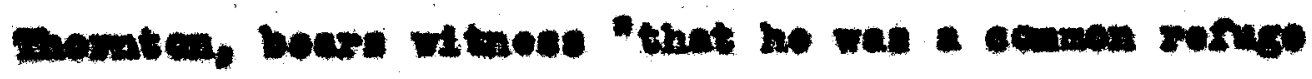

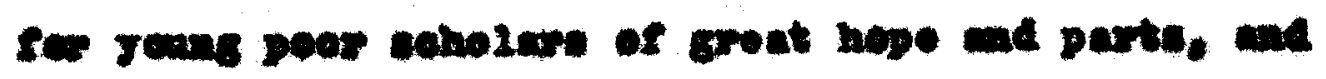

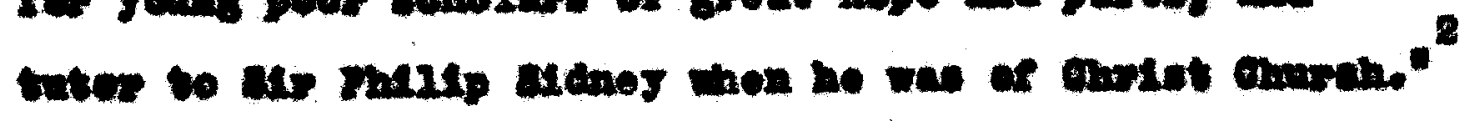

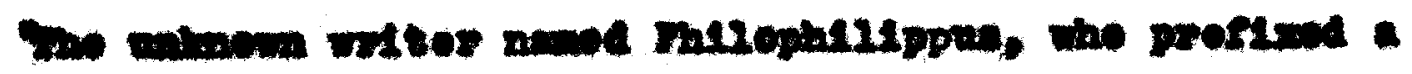

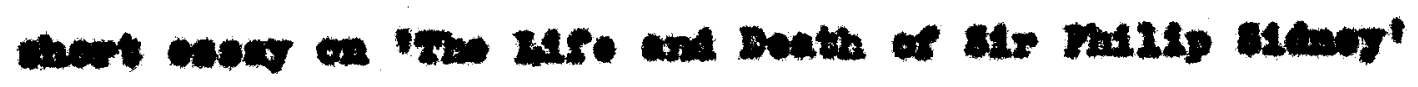

2 Evinav. De nos. is

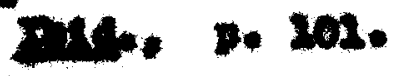




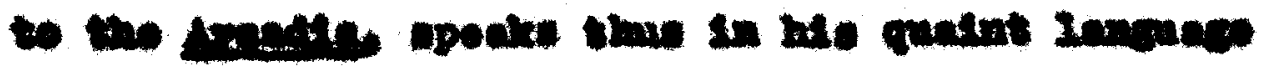

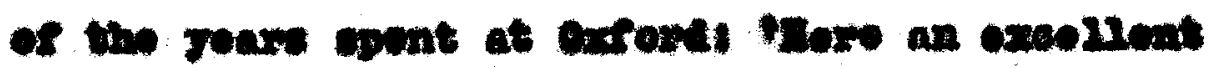

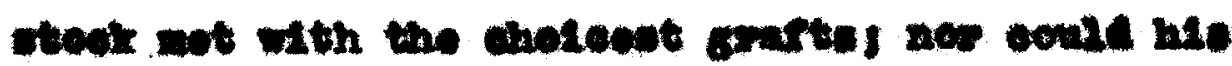

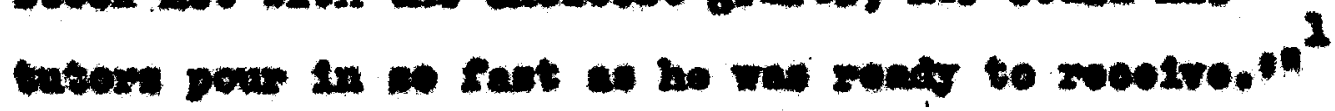

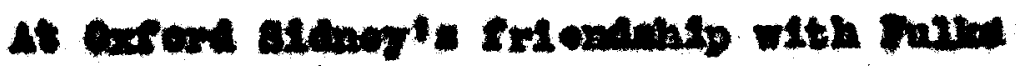

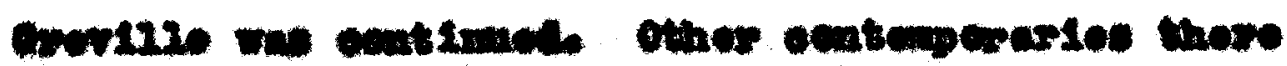

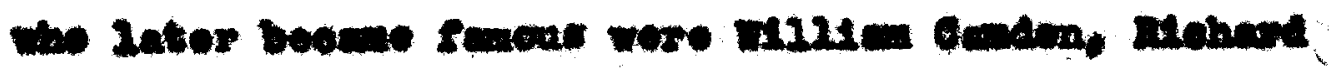

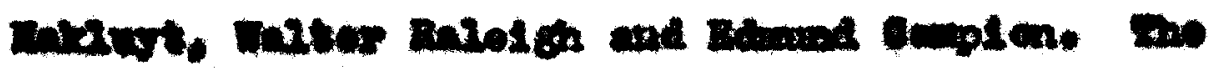

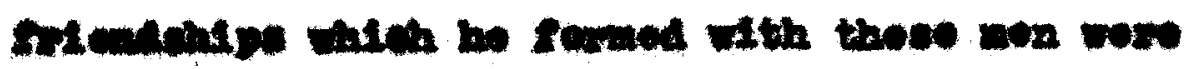
xatine.

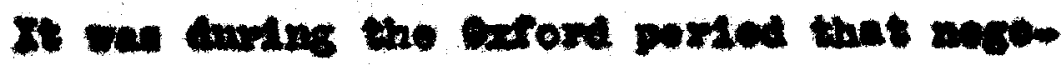

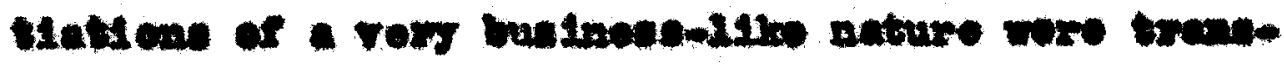

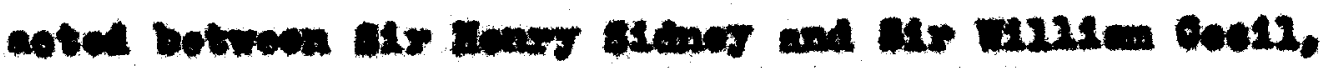

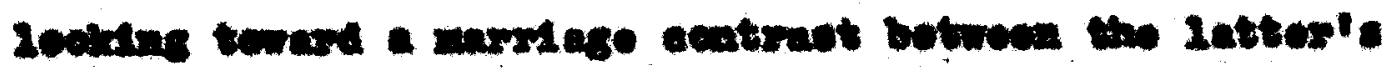

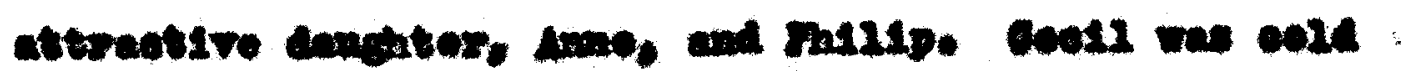

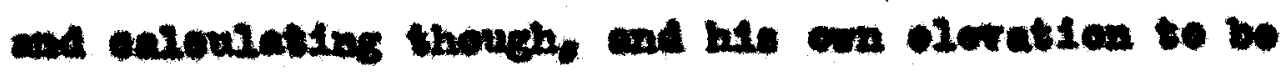

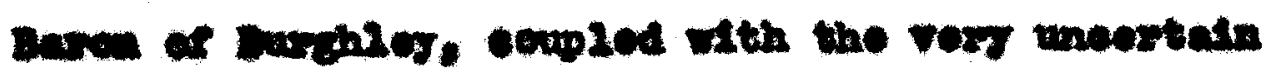

2

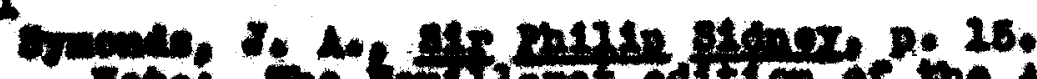

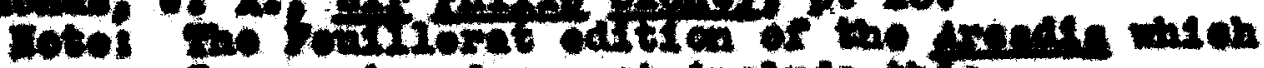
3 anting doos not inind wio. 


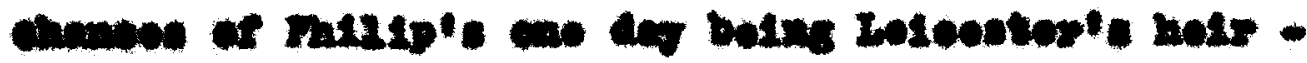

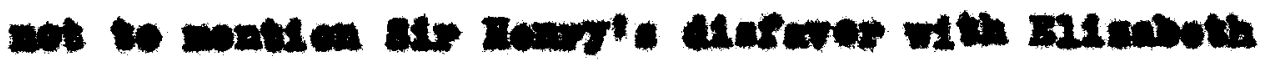

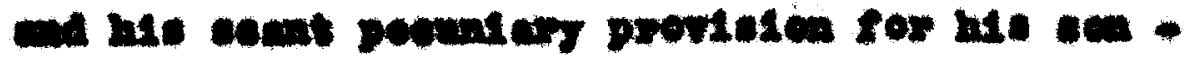

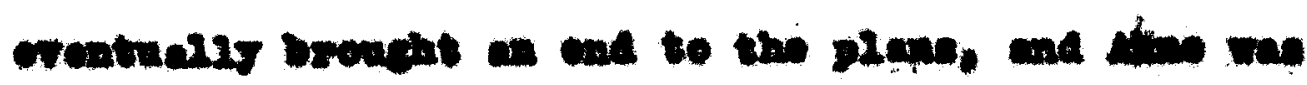

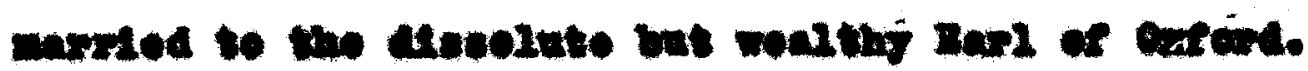
milis wa now in hle elghtecontin reas, with

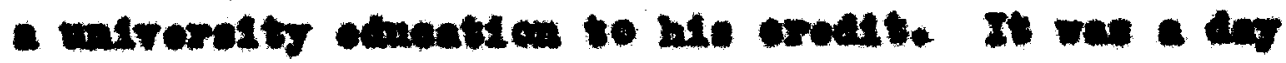

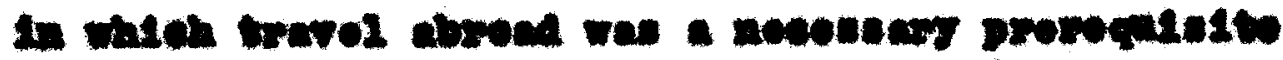

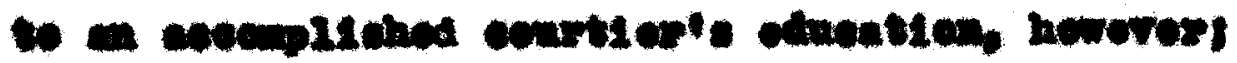
nowe wo red that

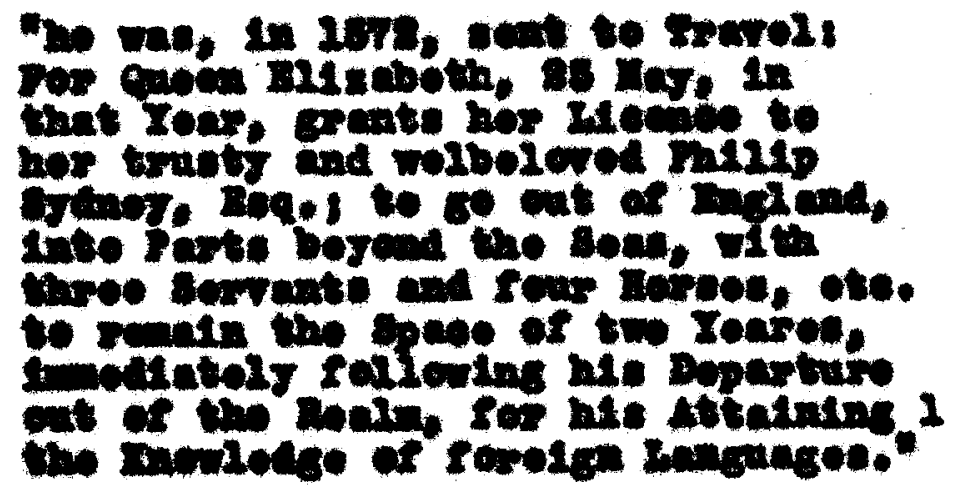

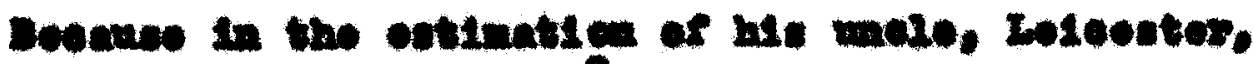
wo wes "yeane an san," ho wont equippod with a

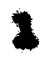

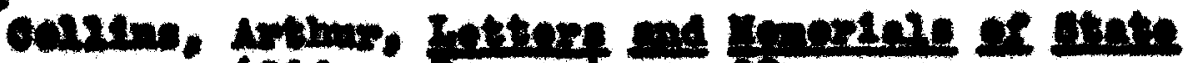
9

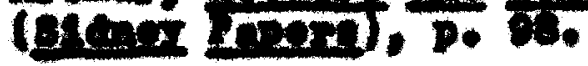
Den Bvaras, pe se. 


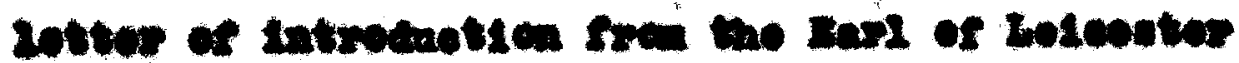

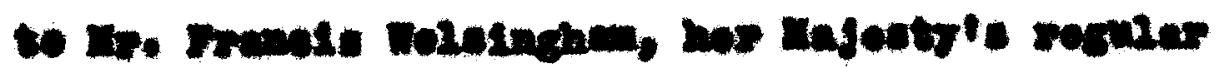

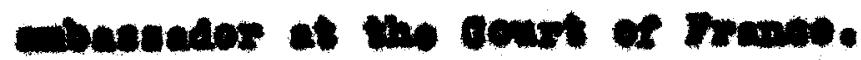

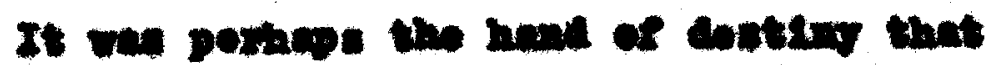

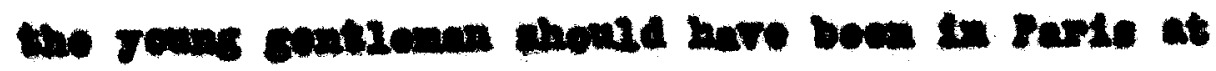

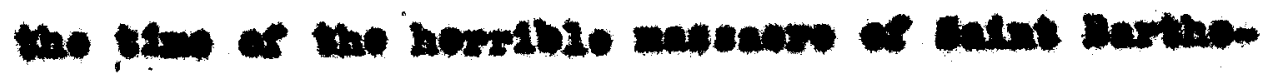

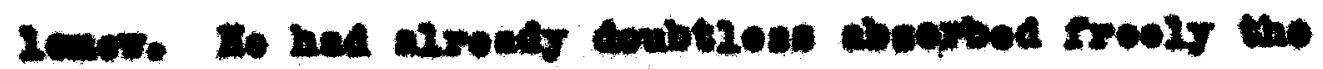

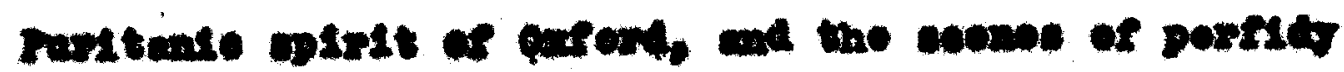

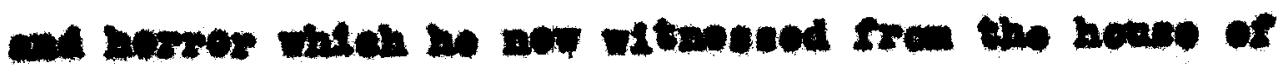

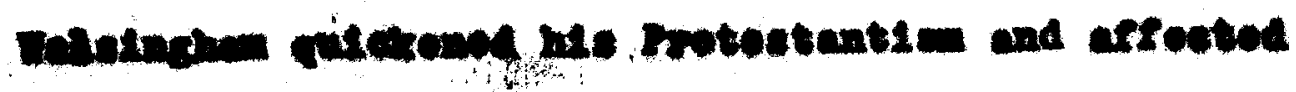

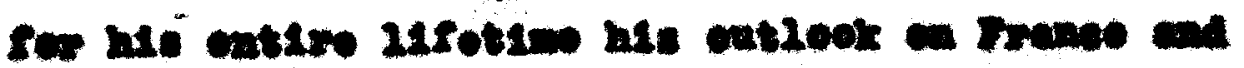
cathoueder.

Io opont not two roans, an dontgonted in

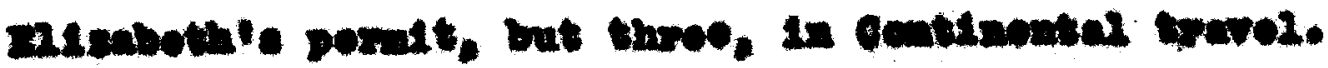

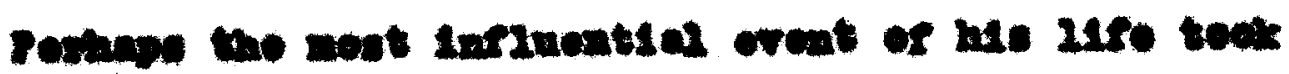

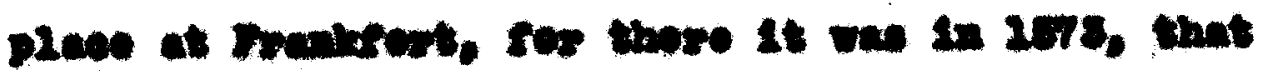

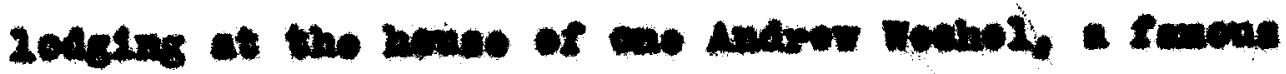
pulater, ho not mebert heaguot, the was to bowene hle

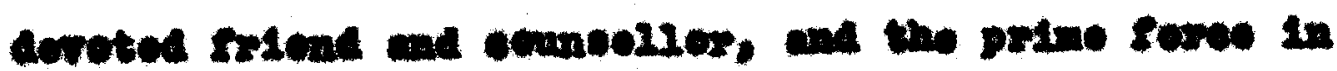
we anping of his ruture eduentien she politieal 


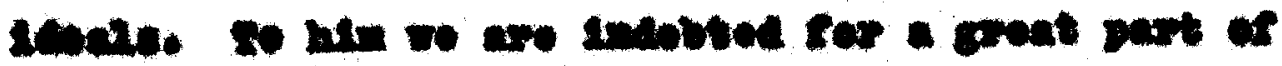

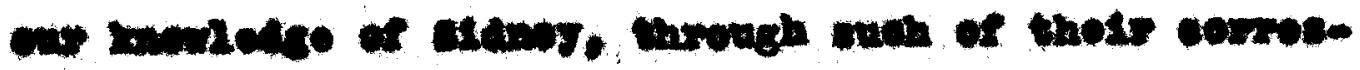

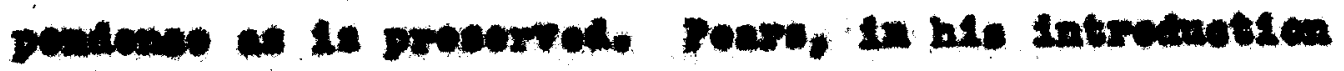

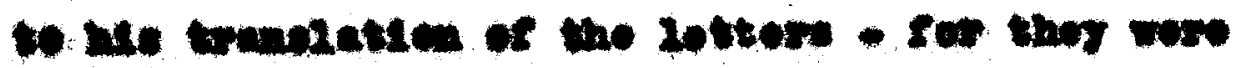

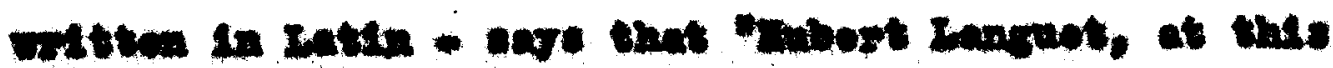

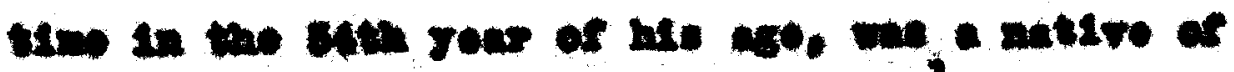

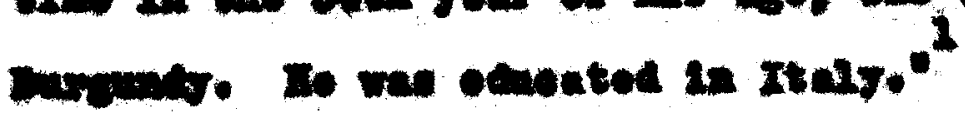

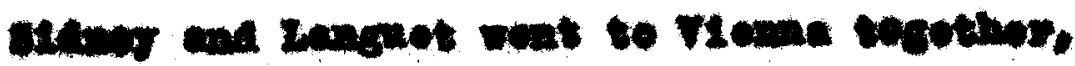

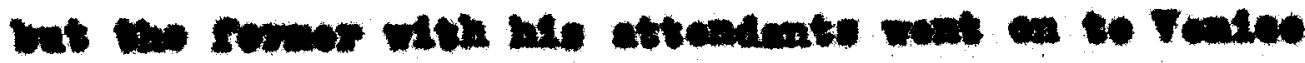

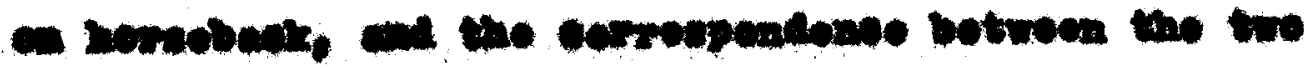

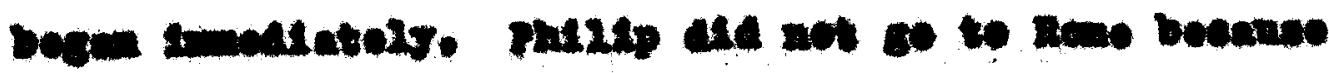

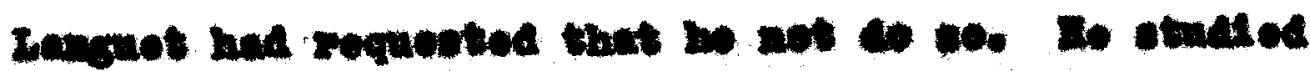

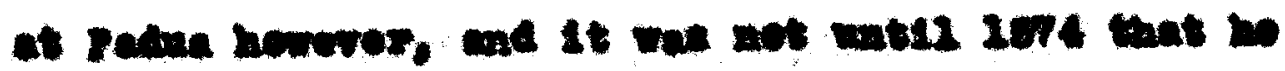

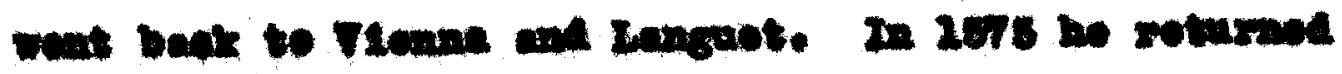
te ranime.

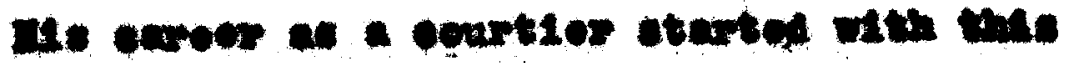

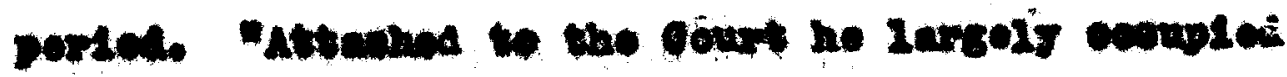

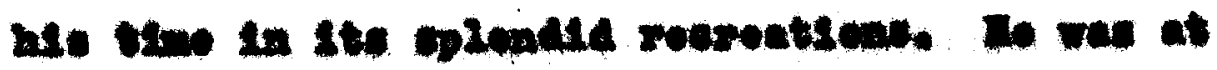

$\mathbf{2}$

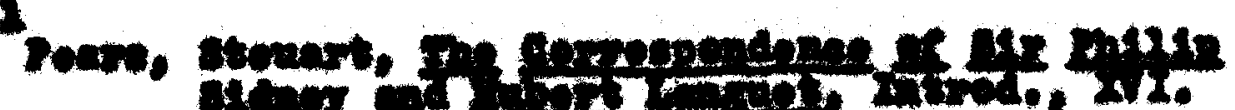

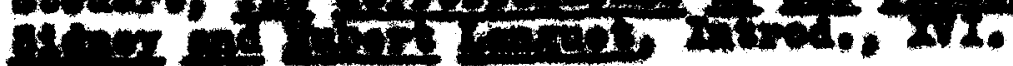




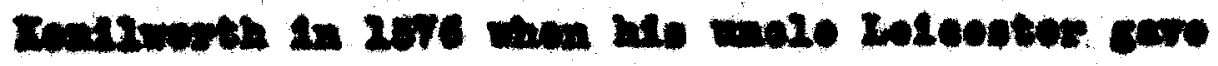

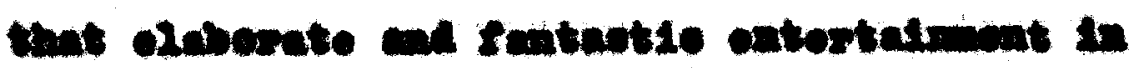

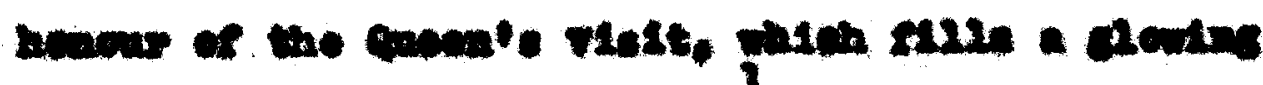

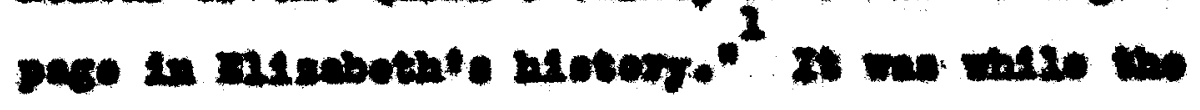

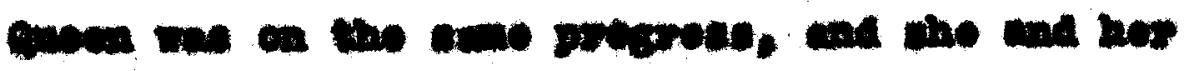

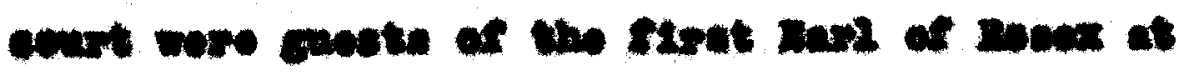

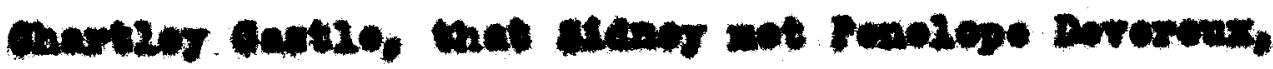

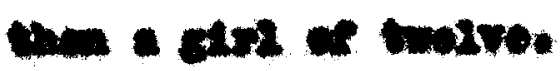

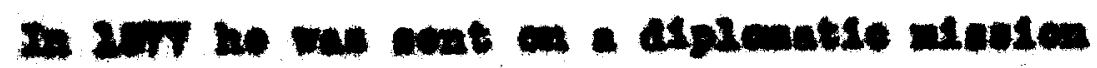

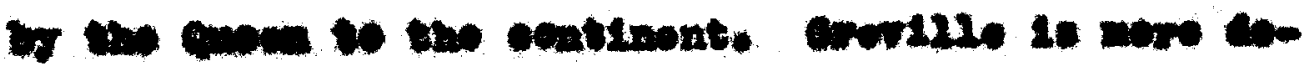

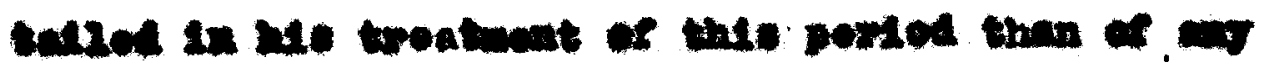

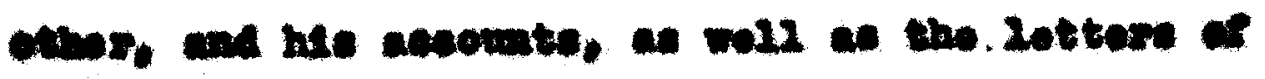

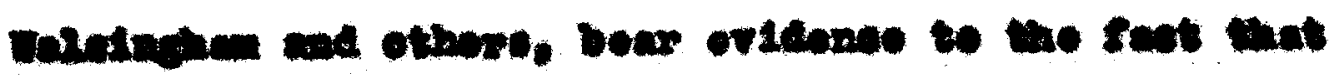

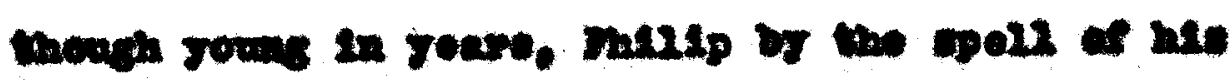

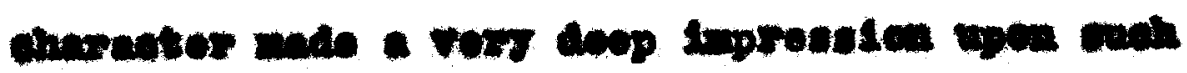

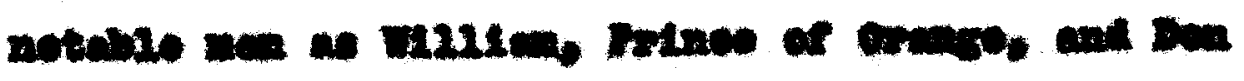

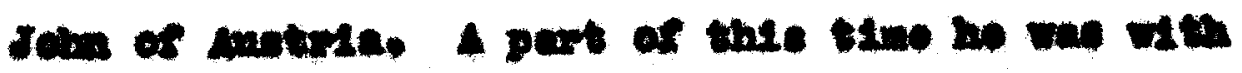
raget.

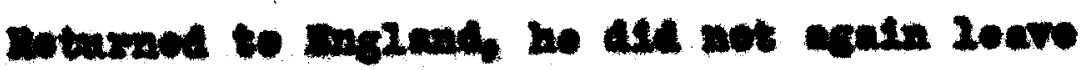

2

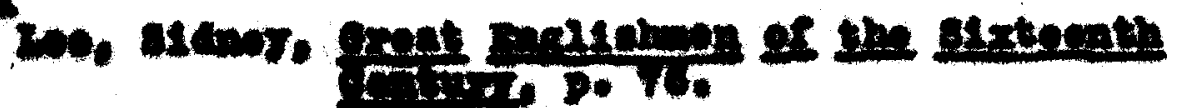




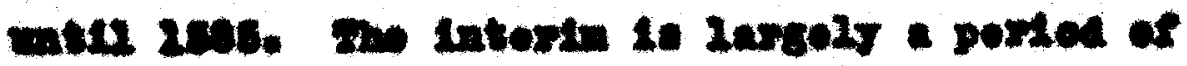

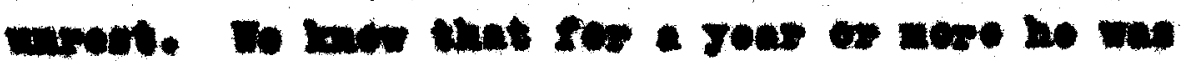

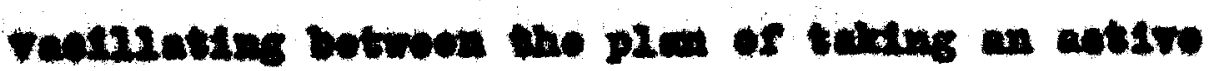

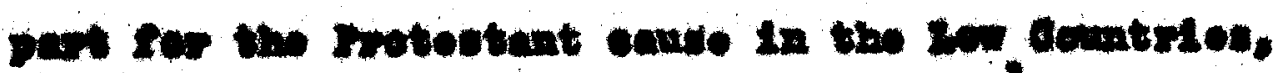

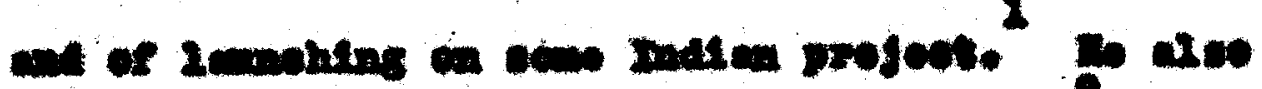

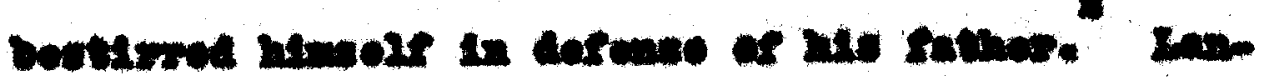

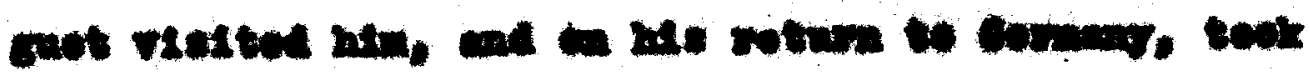

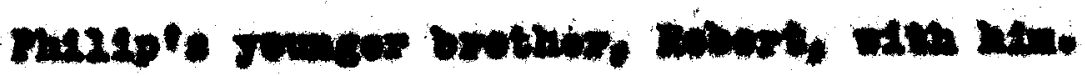

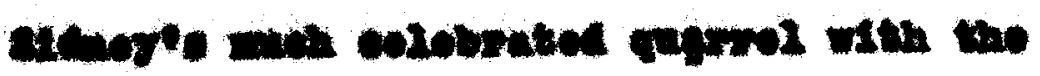

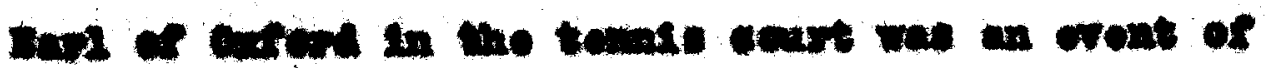

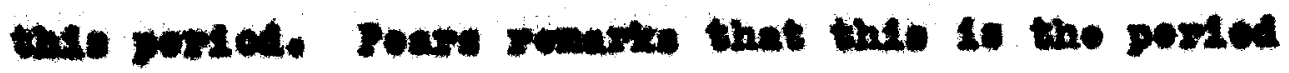

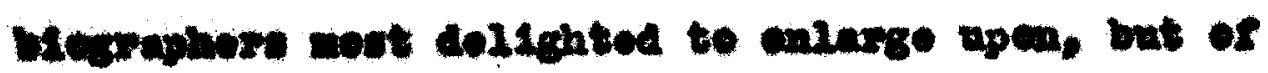

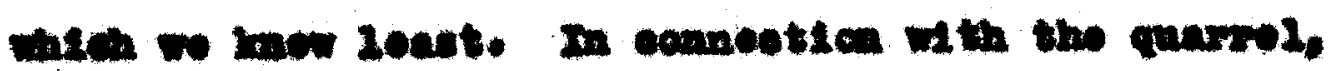

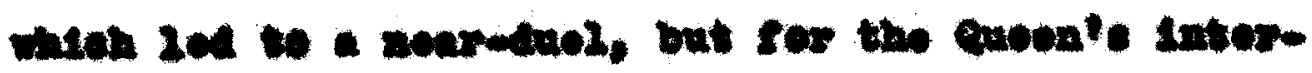

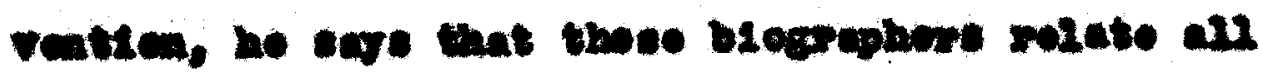

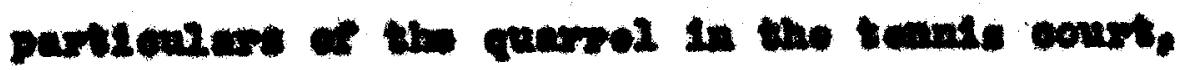

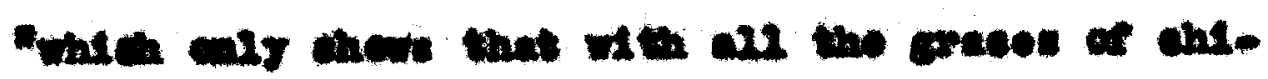

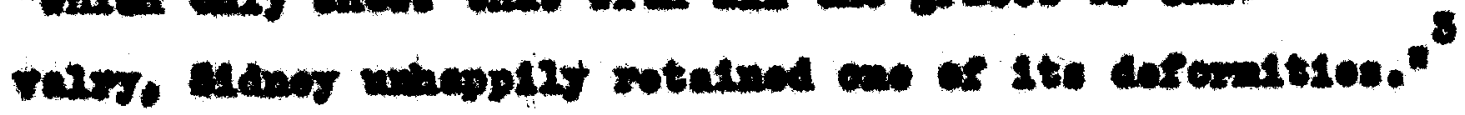

1

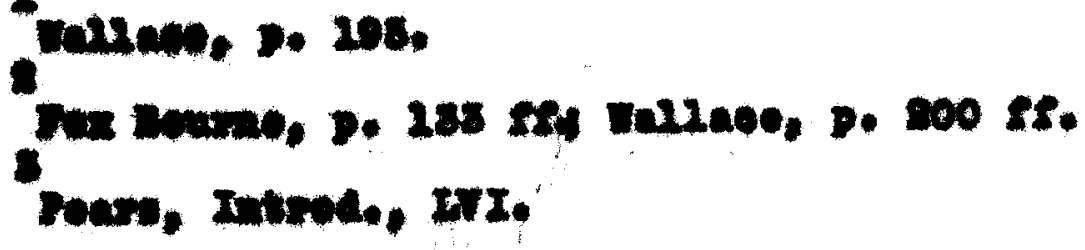


$-20$

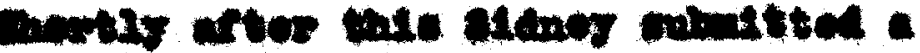

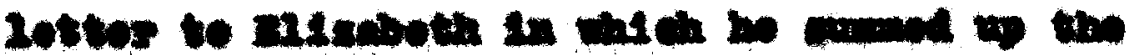

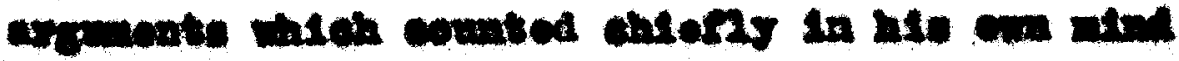

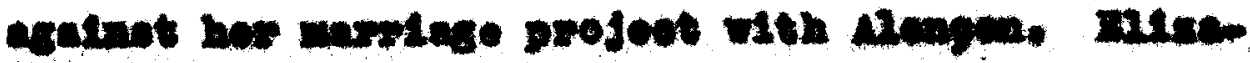

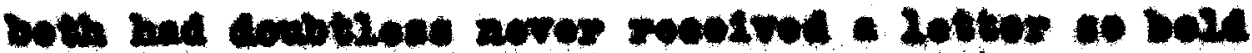

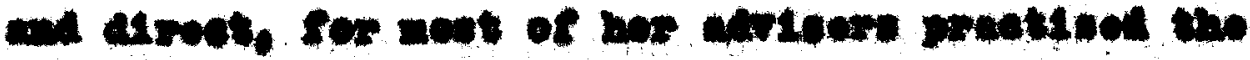

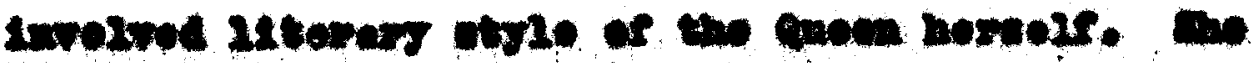

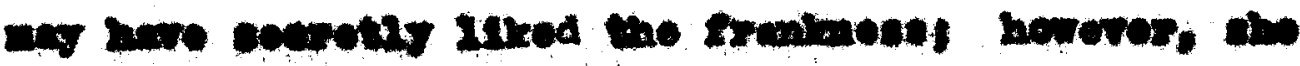

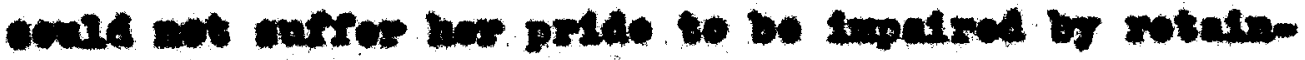

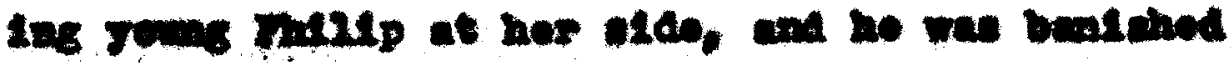
srom courte.

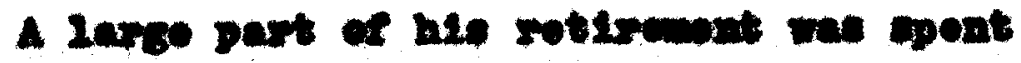

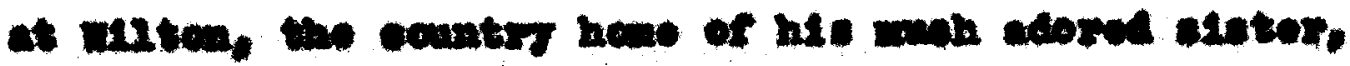

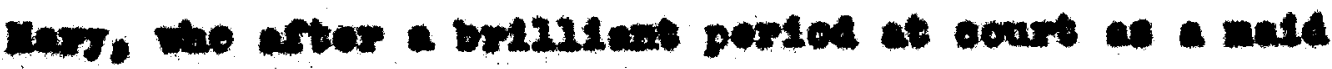

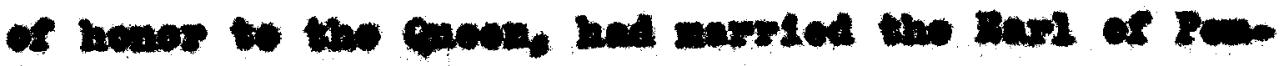

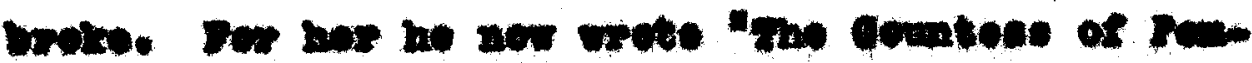
brimele sanite.

Wh wat soen back at opurt, and harkes the

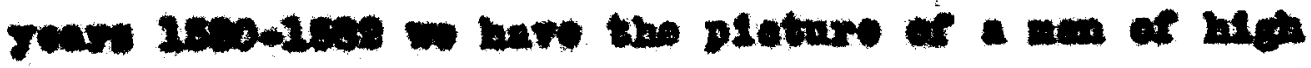

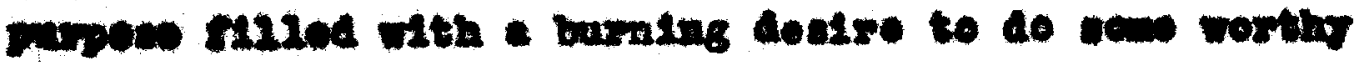




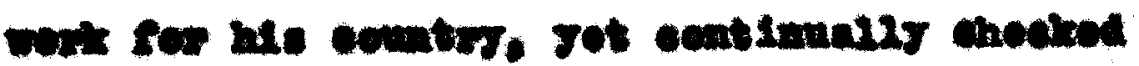

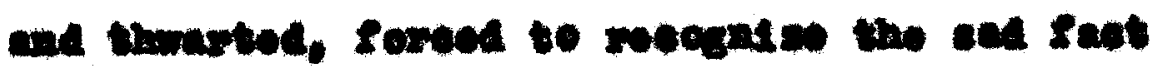

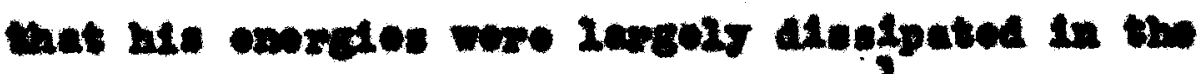

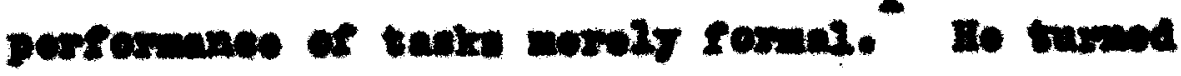

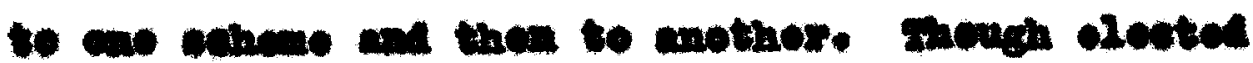

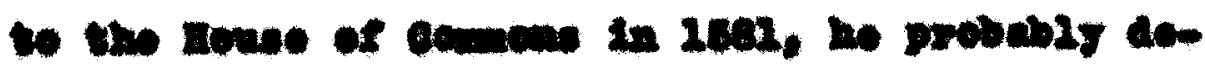

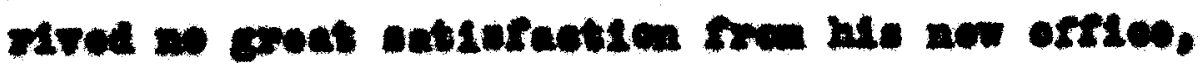

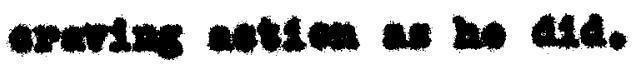

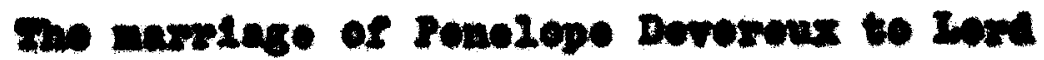

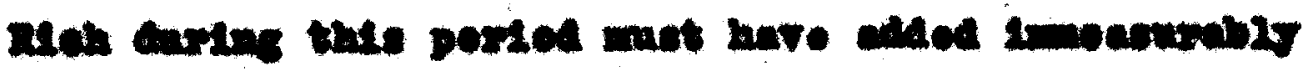
to the alsquitotras of his wind.

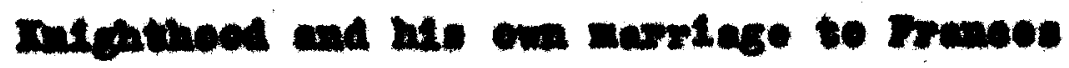

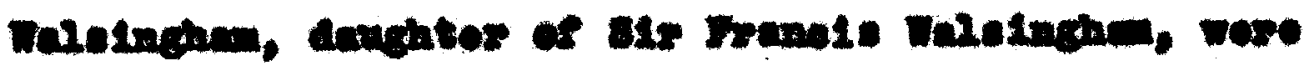

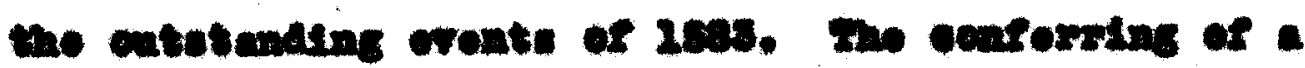

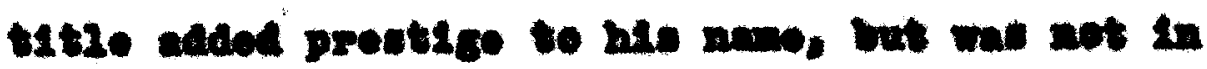

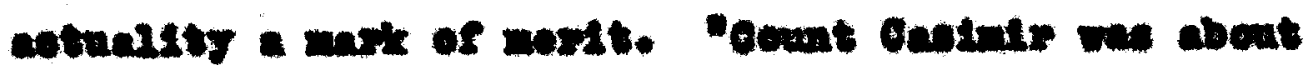

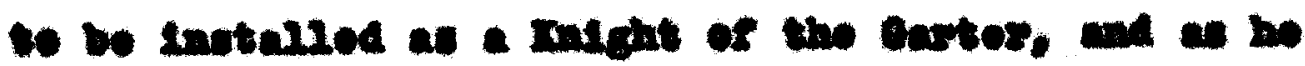

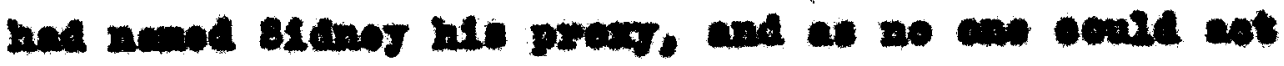

2

Danos, p. Ert. 


$$
-2
$$

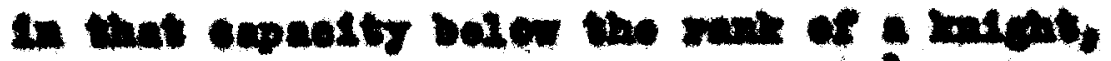

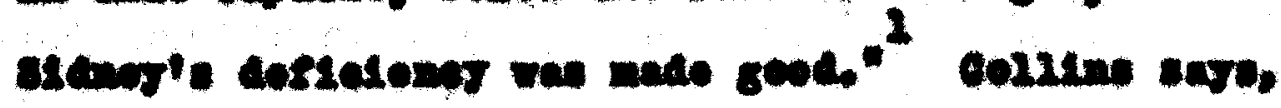

- In 20as, tom, mince ralatino

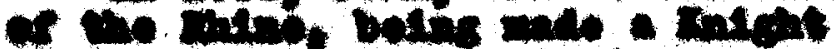

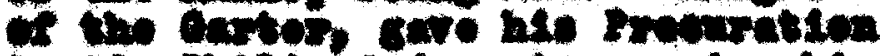

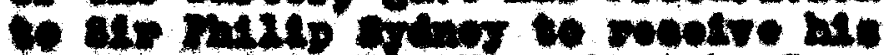

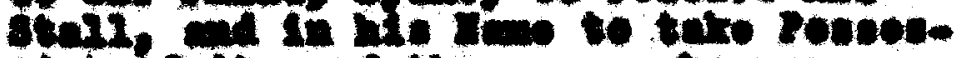

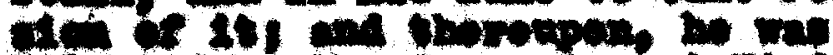

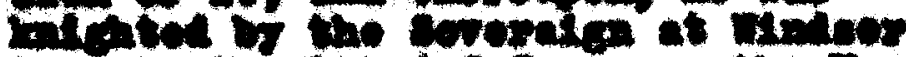

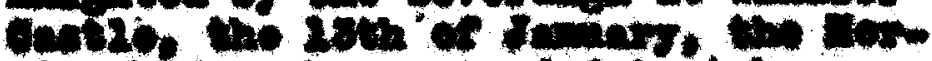

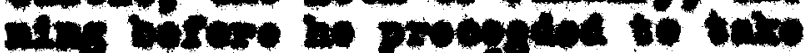

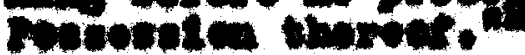

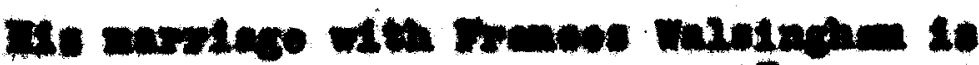
8

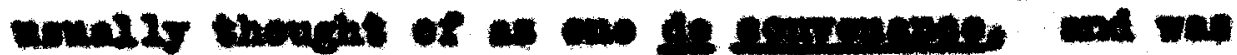

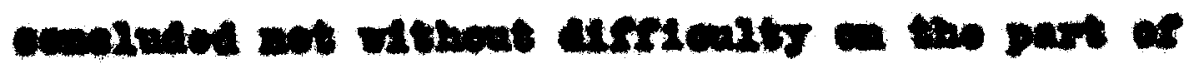

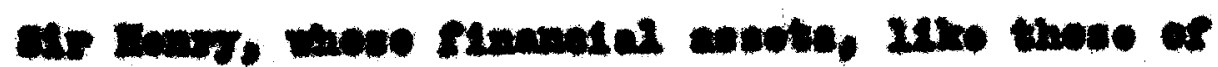

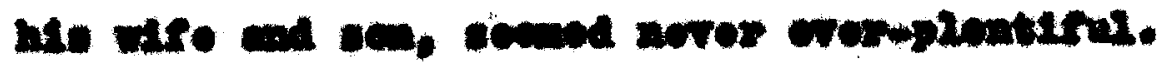

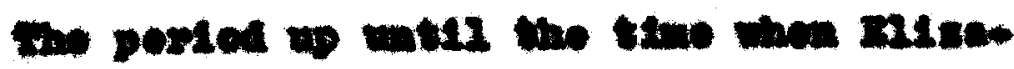

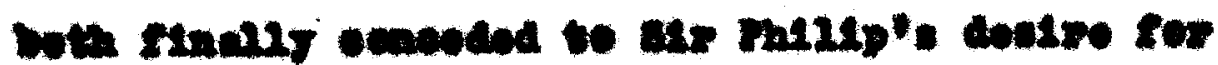

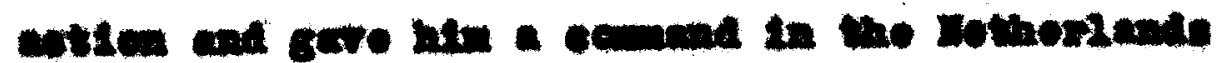

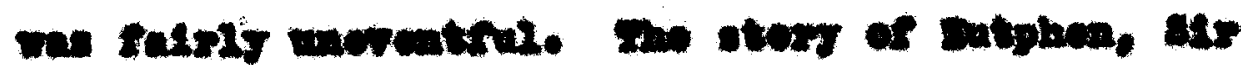

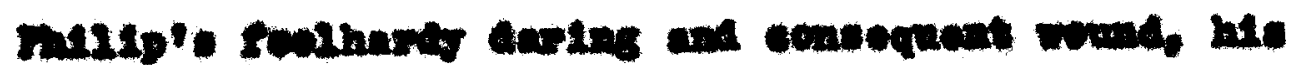

2

nareco, D. 200.

8

colitive, I, 108.

8

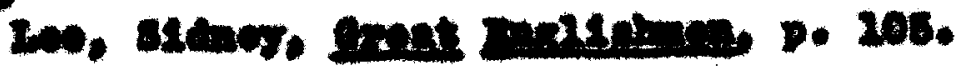




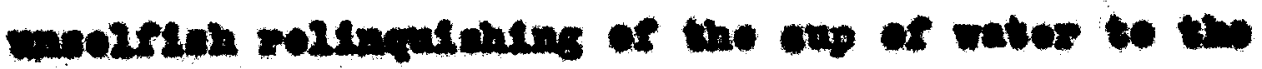

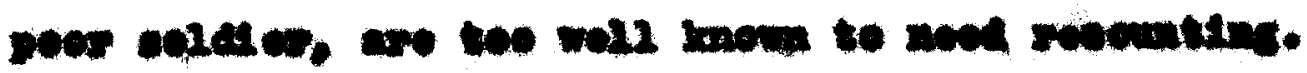

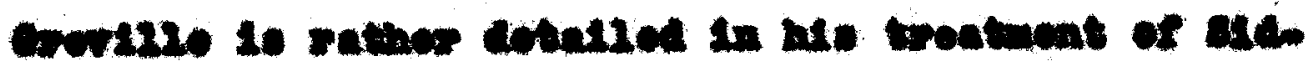

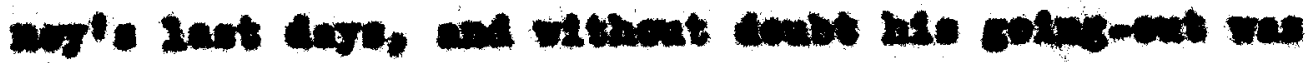

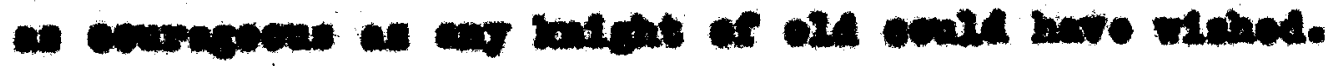
Dowats

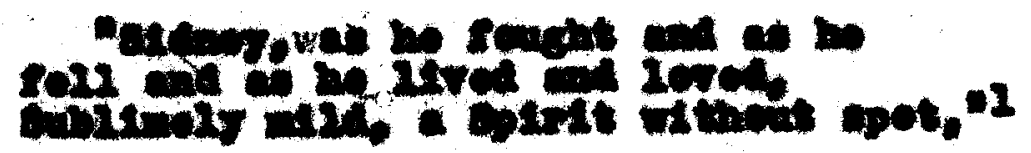

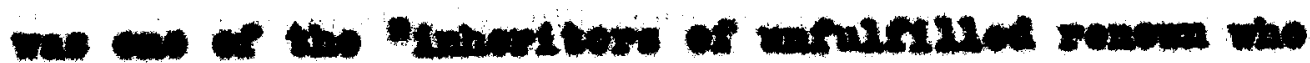

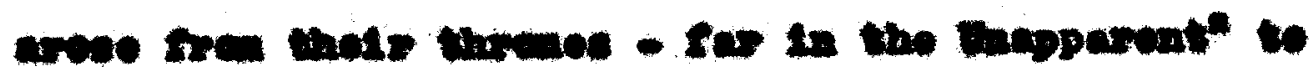

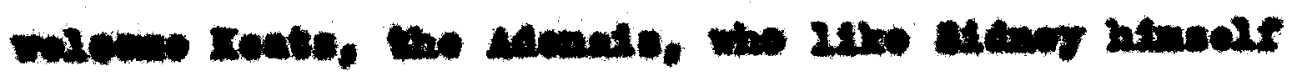

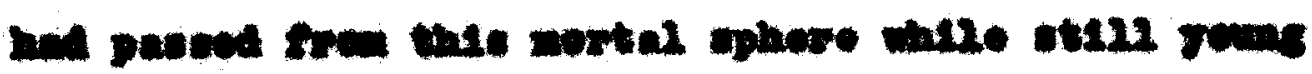
in some.

2

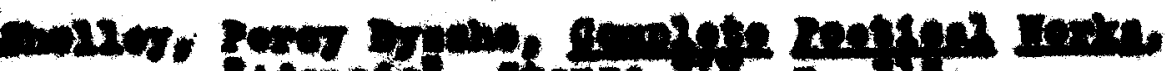

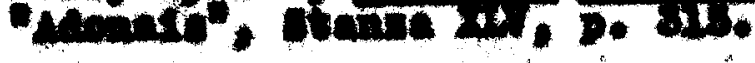




\section{anvin 20

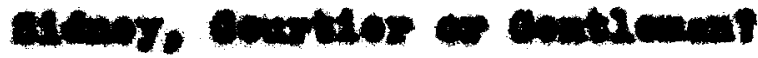

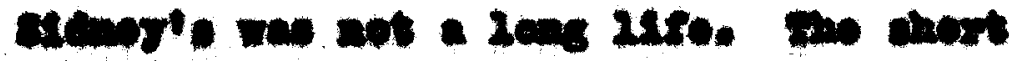

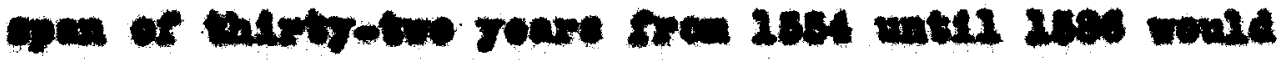

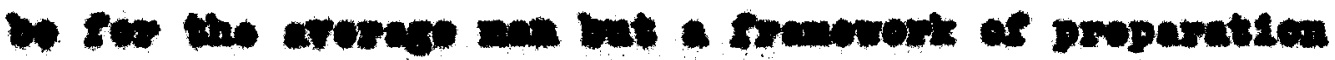

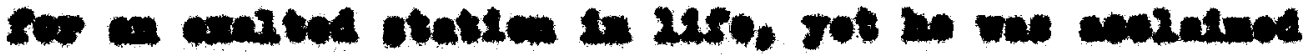

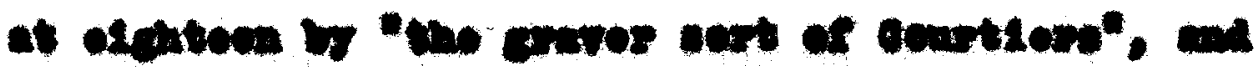

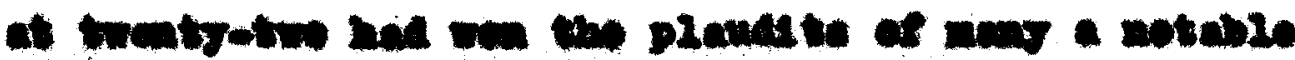

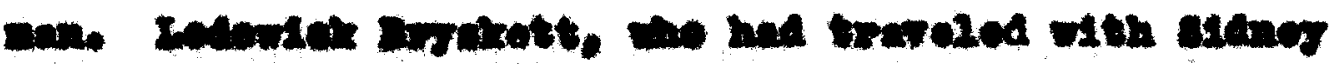

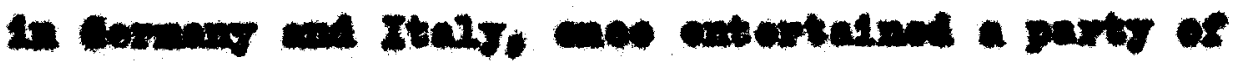

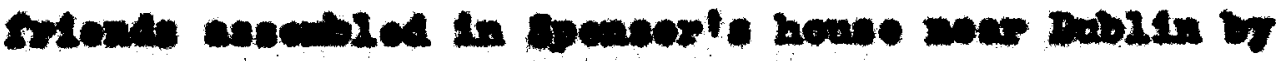

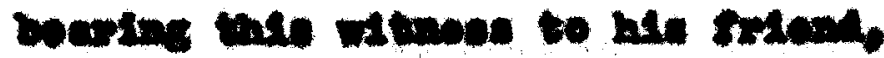

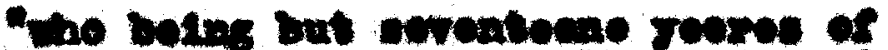

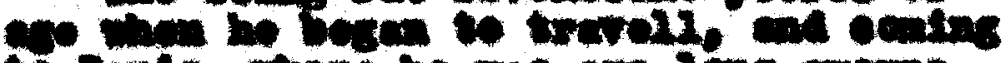

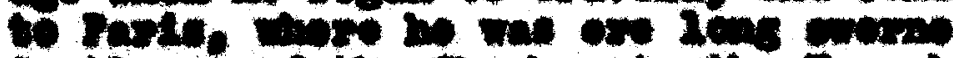

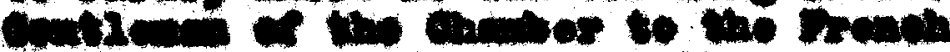

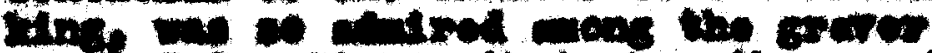

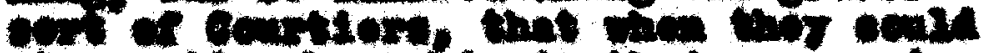

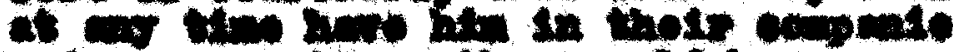

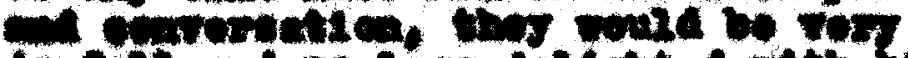

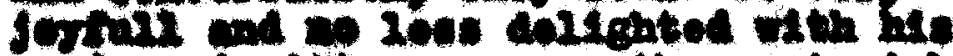

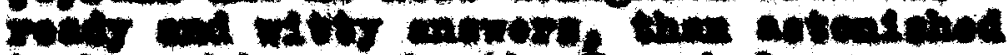

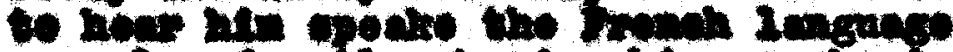

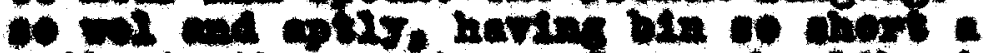

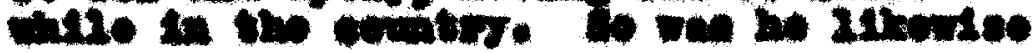


octeren in all pleace ato bow - em in me crarev as wou in

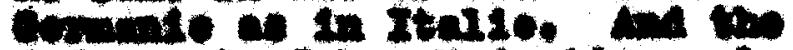

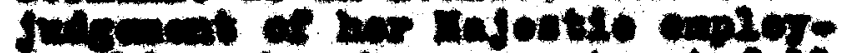

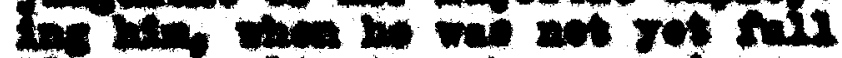

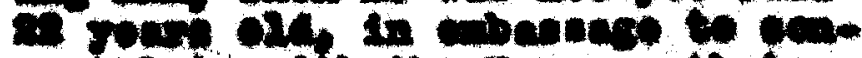

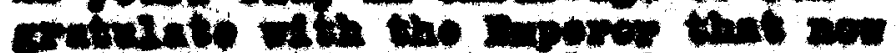

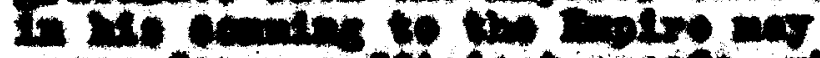

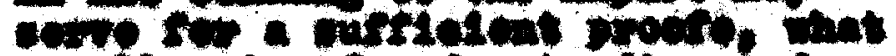

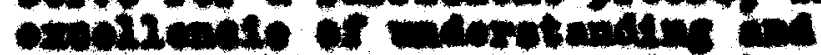

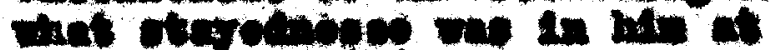

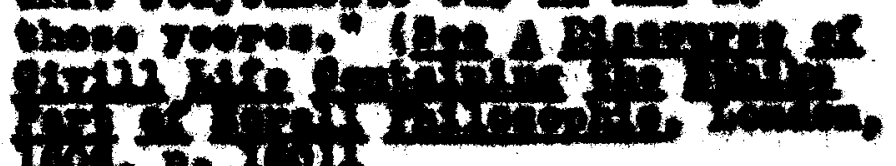

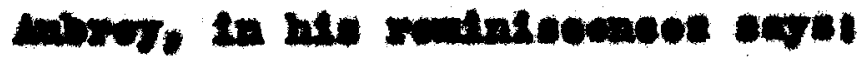

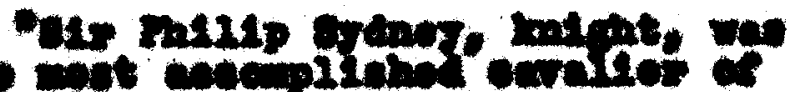

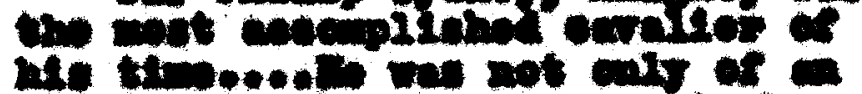

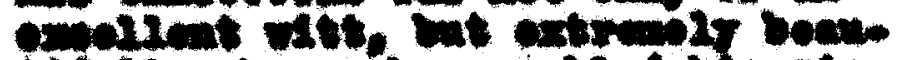

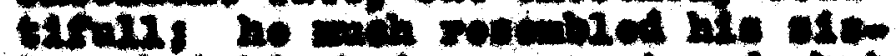

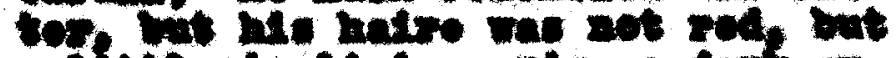

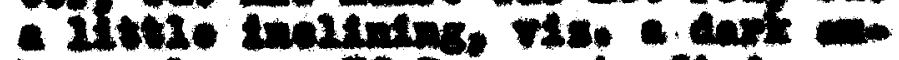

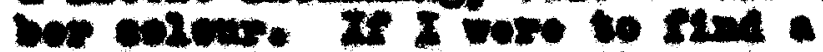

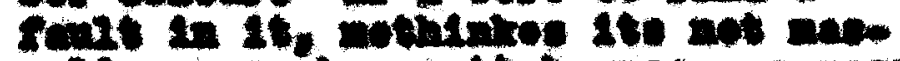

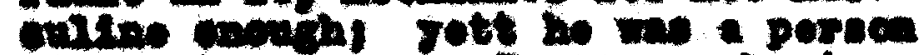

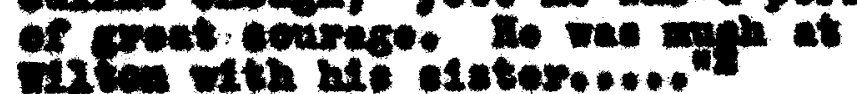

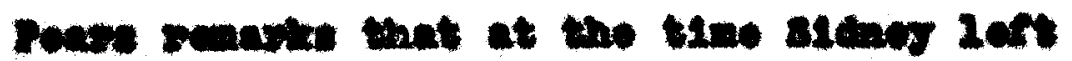

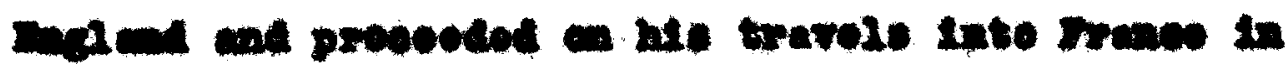

\footnotetext{
2

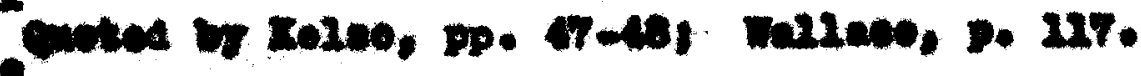

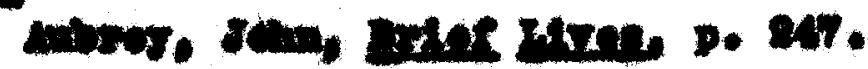




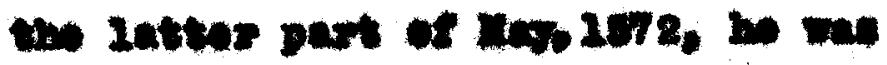

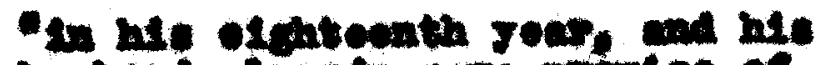

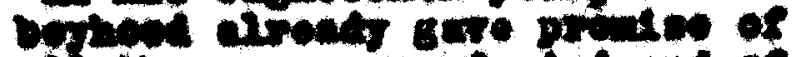
10 thene graces $\alpha$ ath and

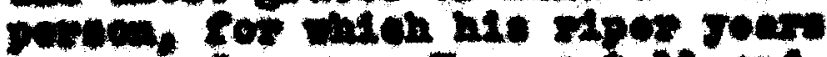

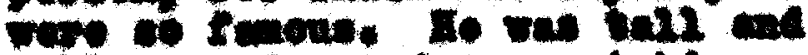

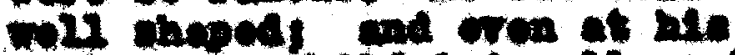

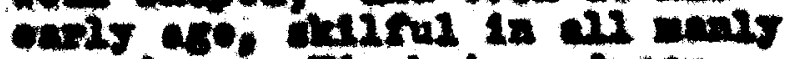

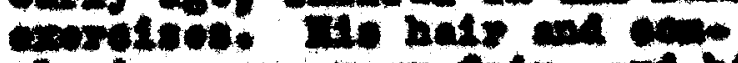

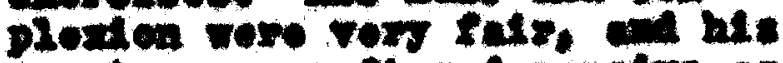

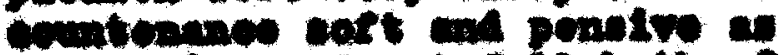

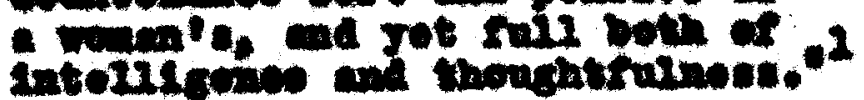

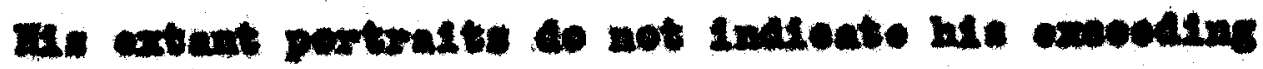
salmoen, wat ther is tostify to the mopolinese of

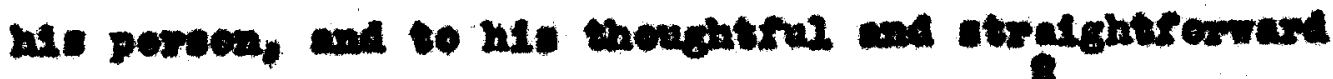

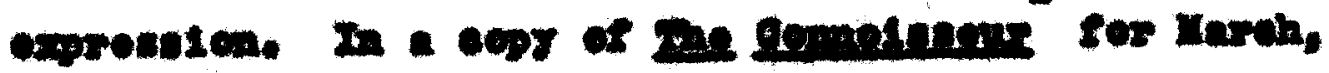

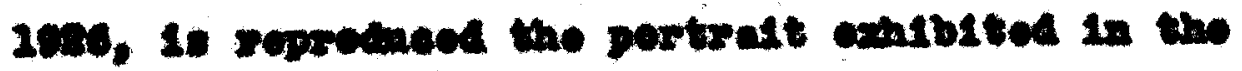

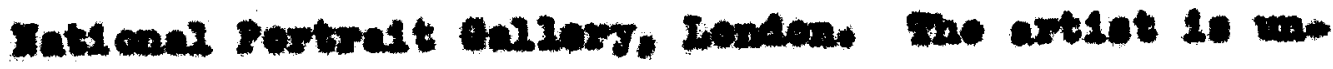

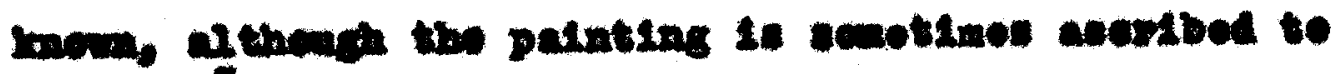

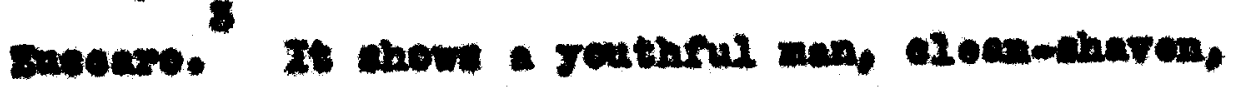

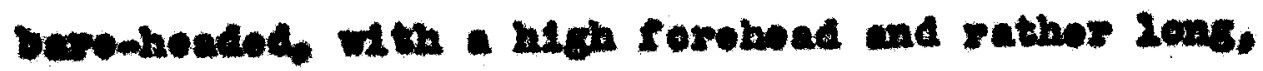

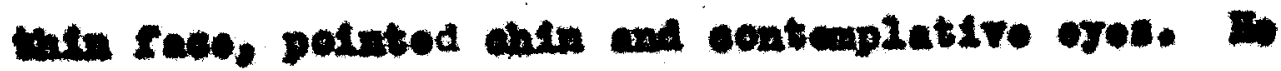

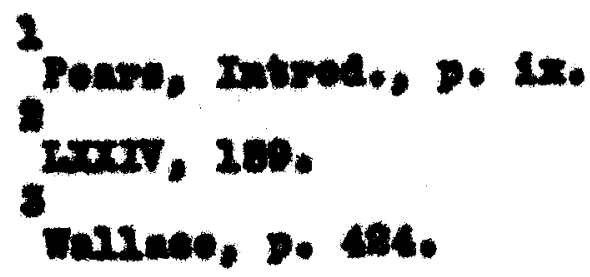




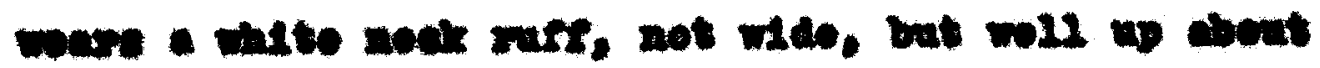

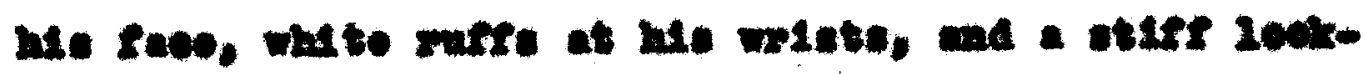

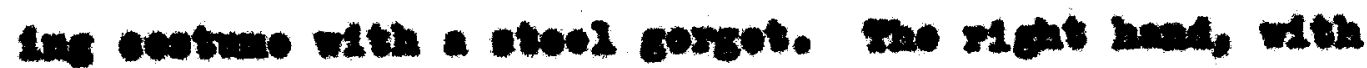

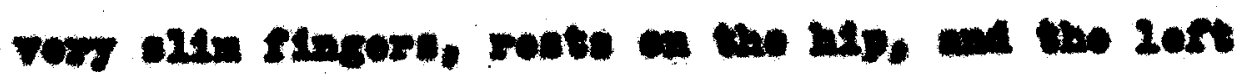
nole the uat at a rowe.

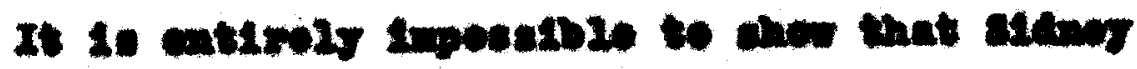

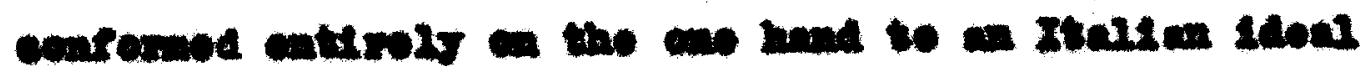

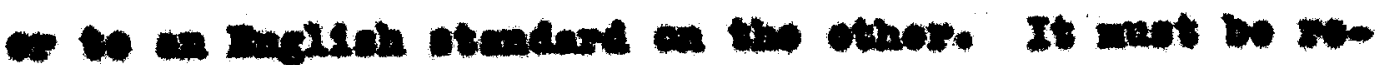

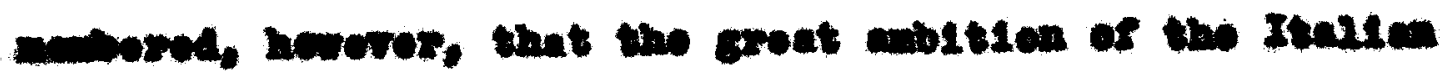

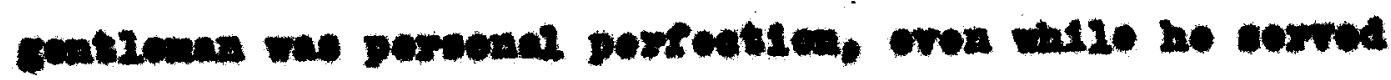

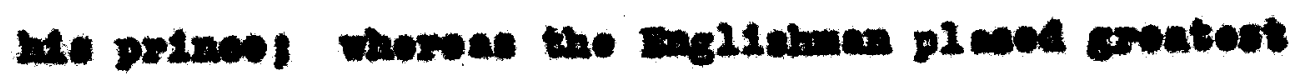

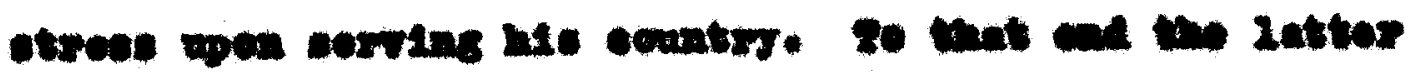

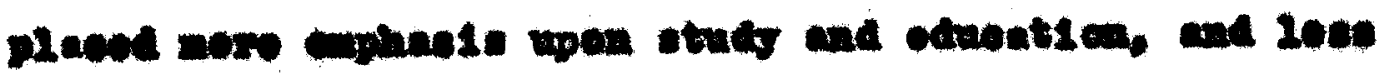

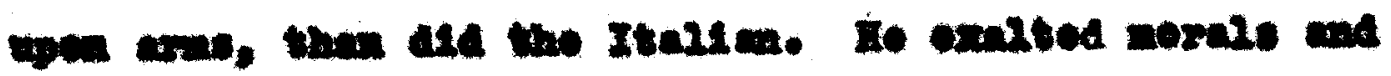

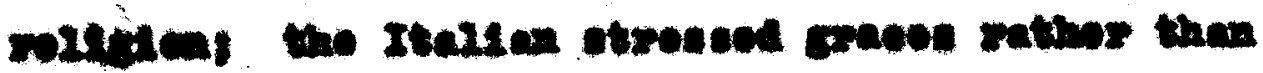

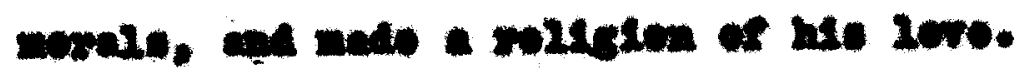

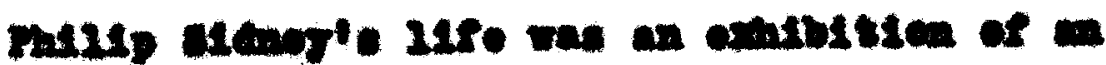

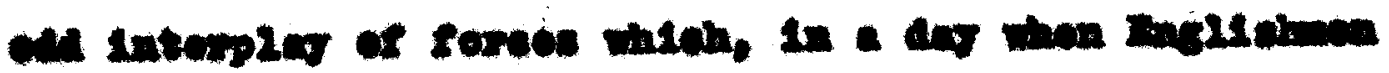

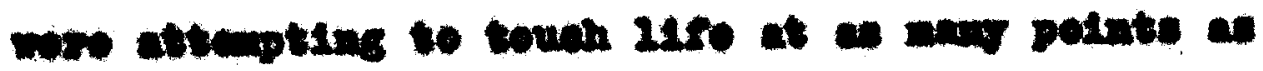

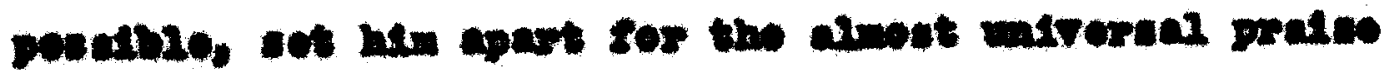




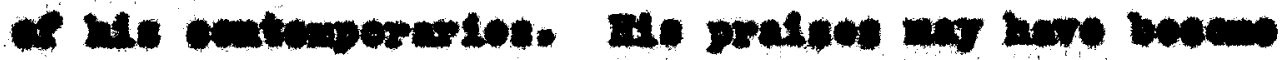

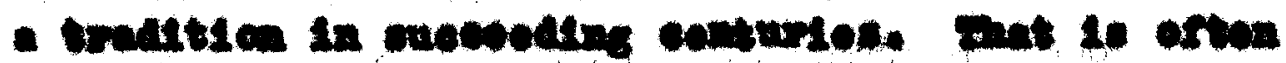

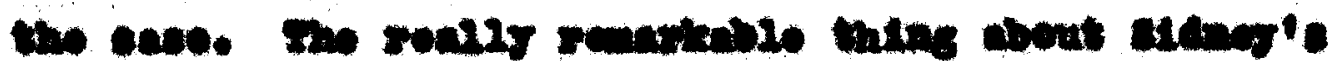

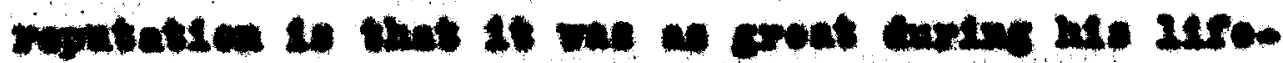

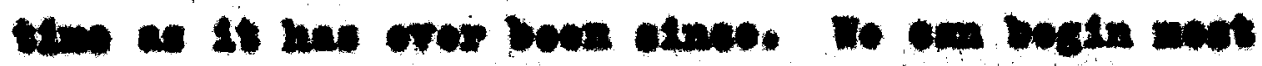

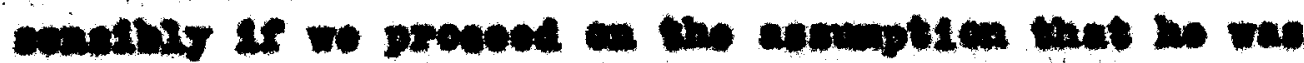

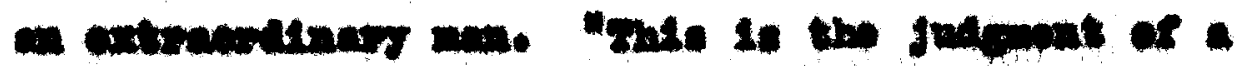

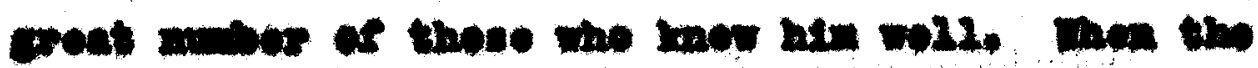

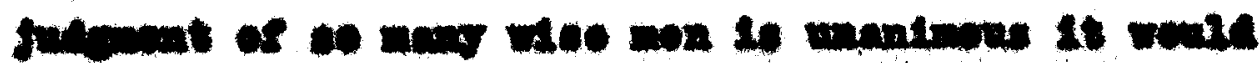

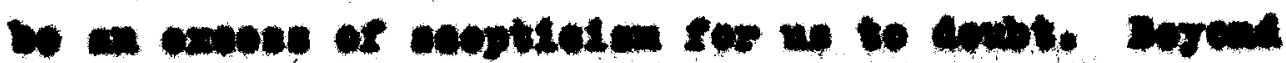

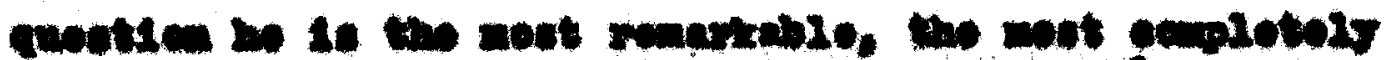

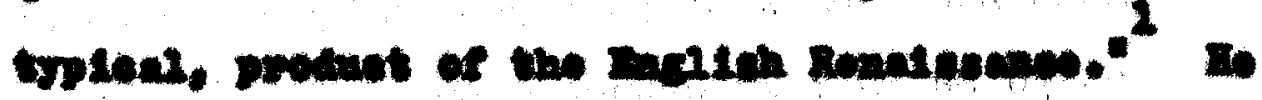

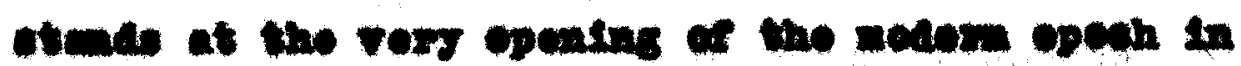

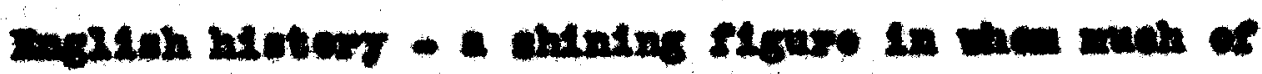

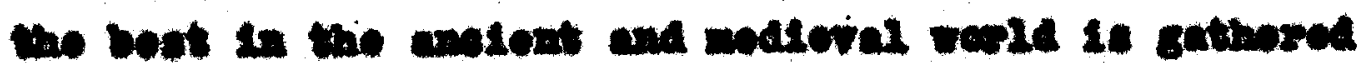

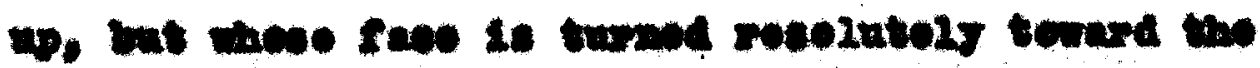

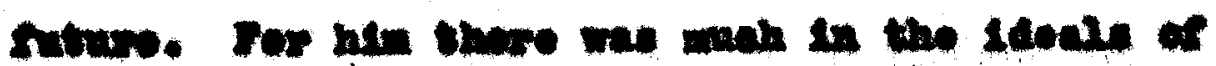

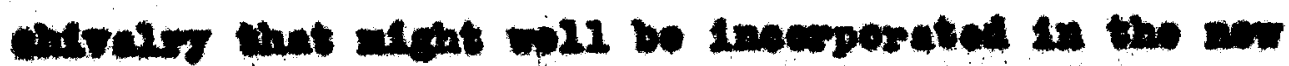

2

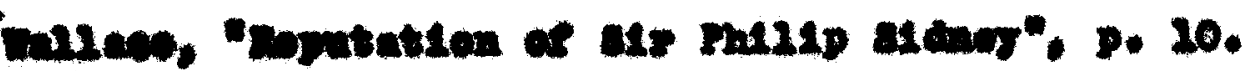




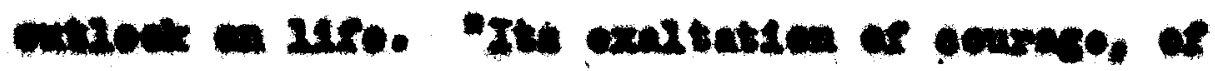

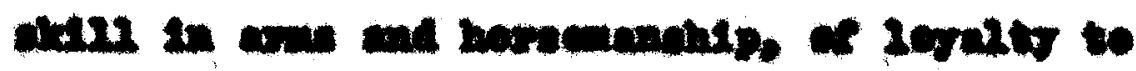

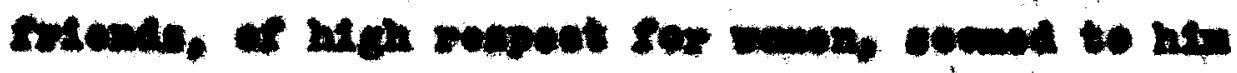

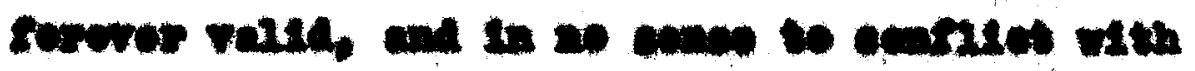

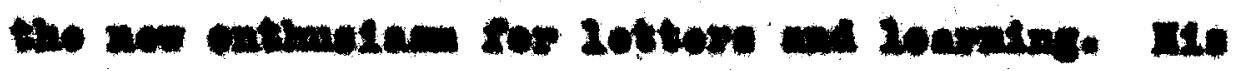

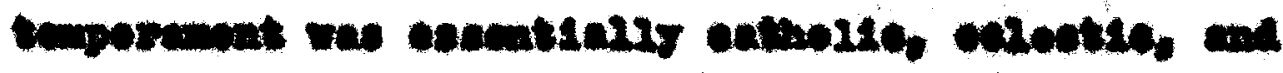

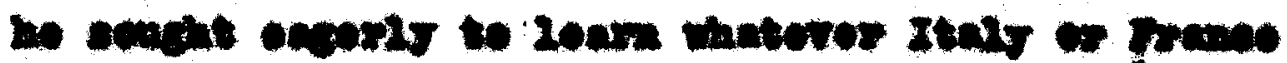

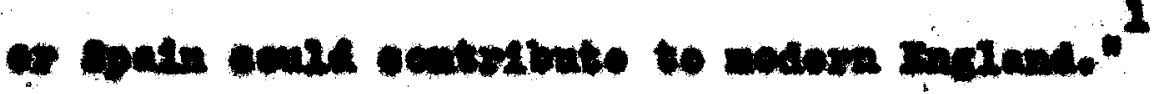

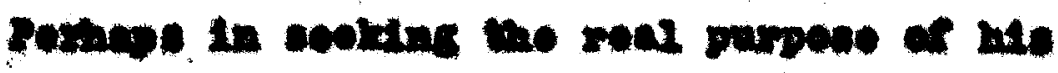

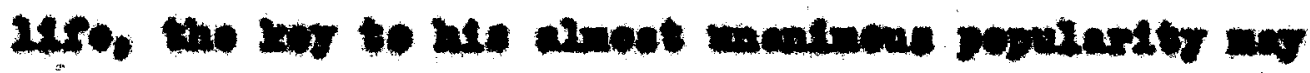

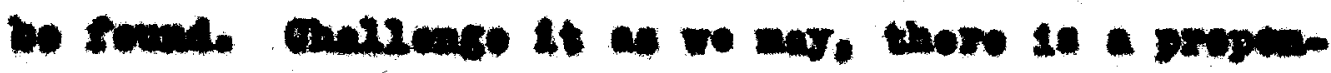

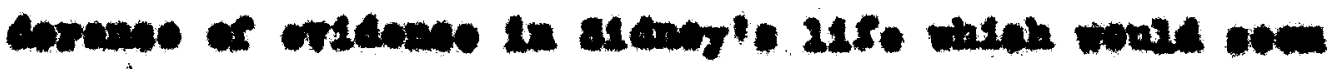

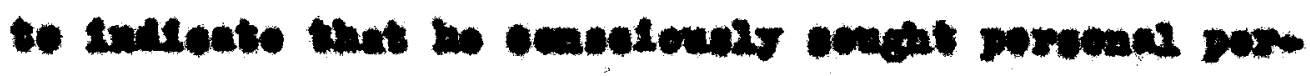

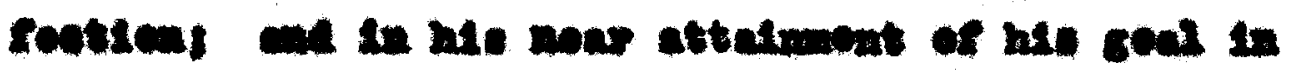

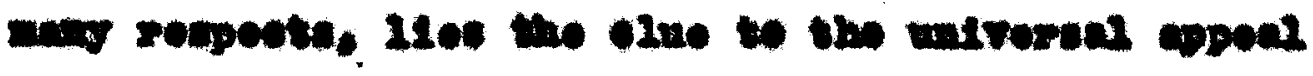

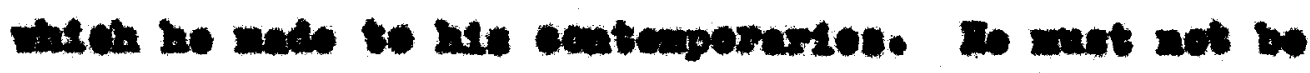

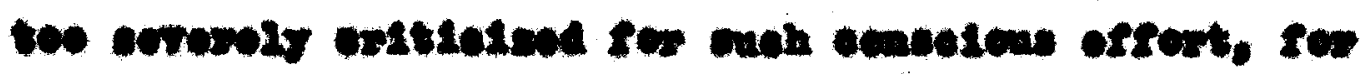

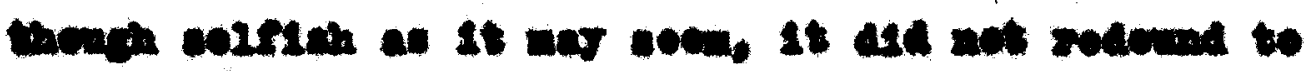

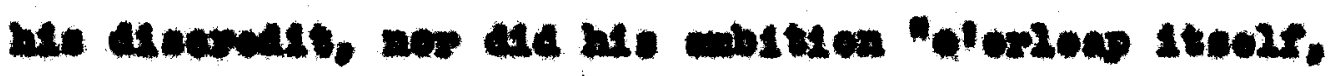

2

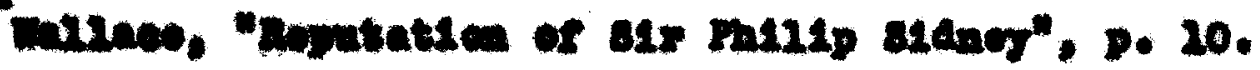




$$
-\infty
$$

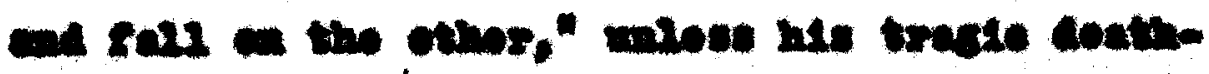

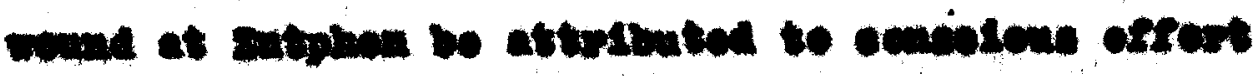

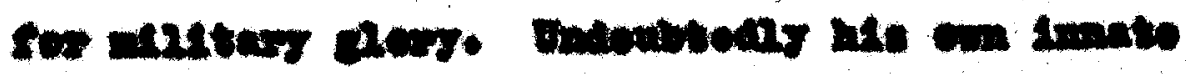

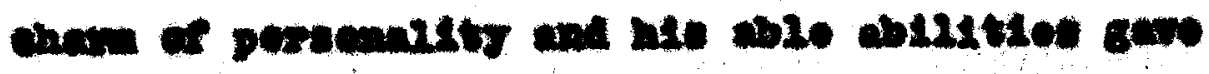

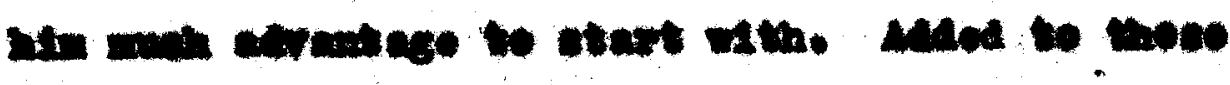

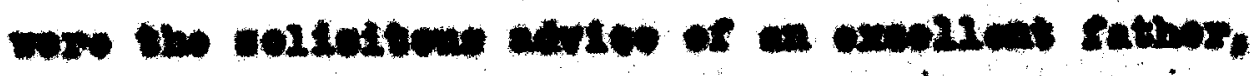

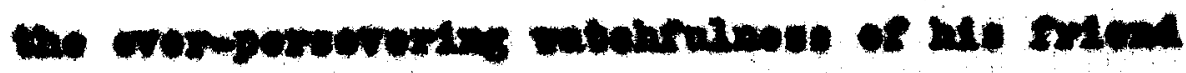

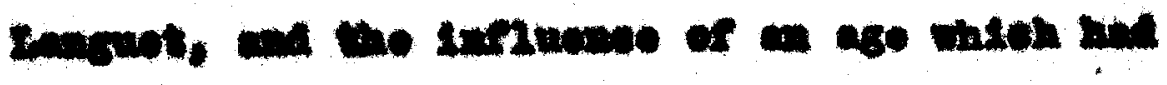

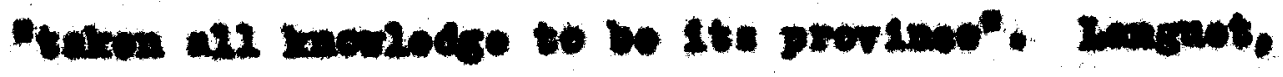

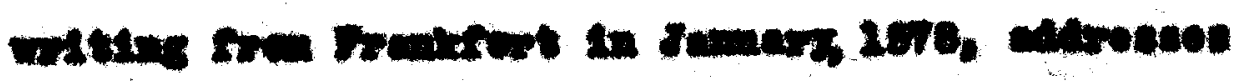
asens of

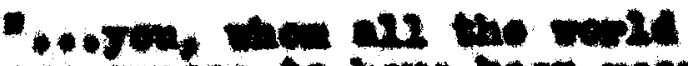

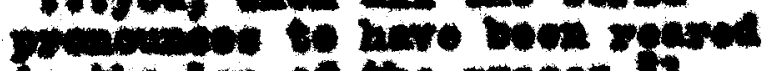

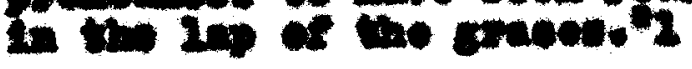

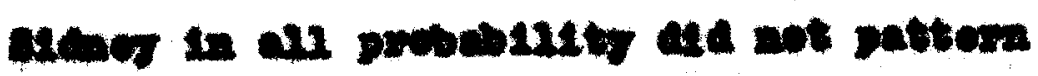

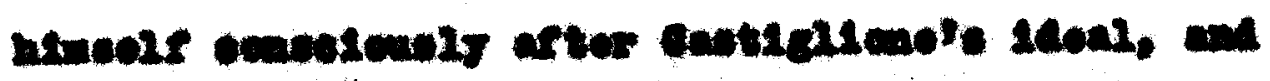

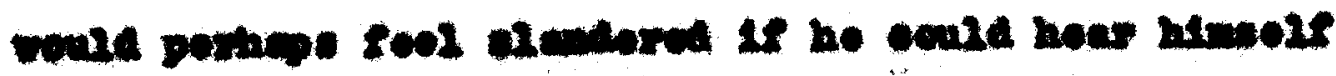

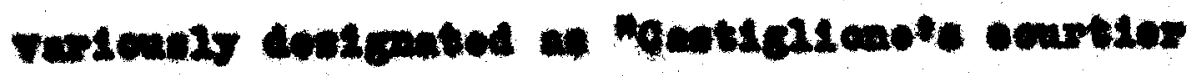

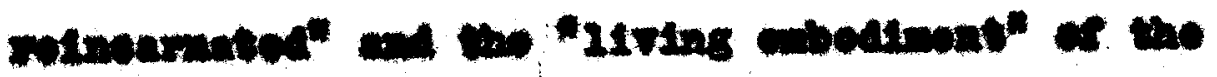

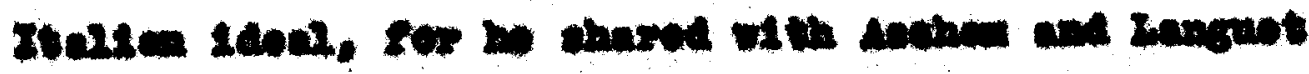

2 reare. 28. 


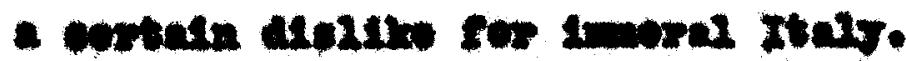

In a Itter to his brother inoert in 1070

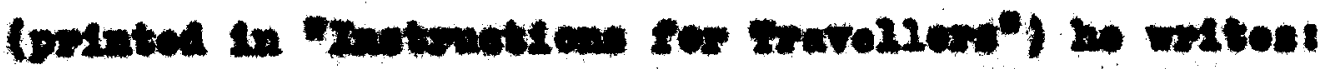

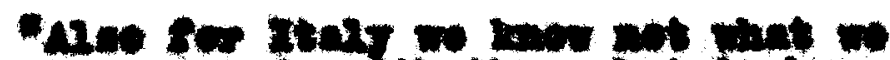

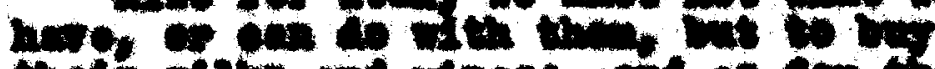

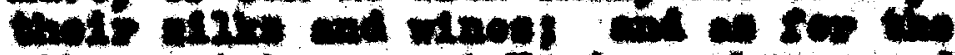

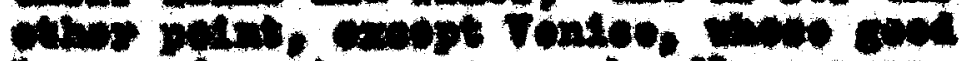

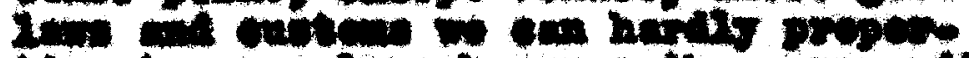

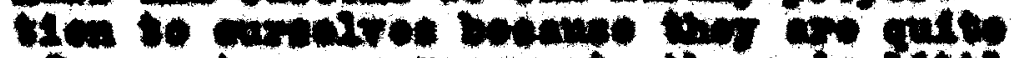

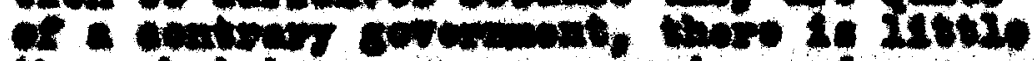

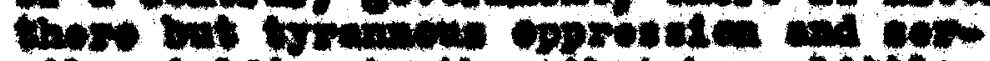

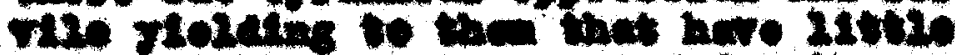

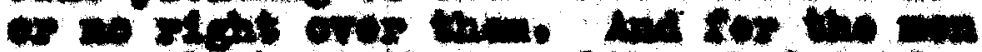
ren thil hav thow, athowo inew

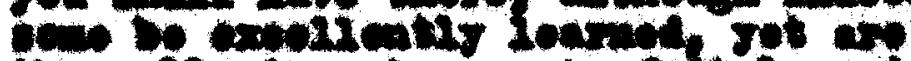

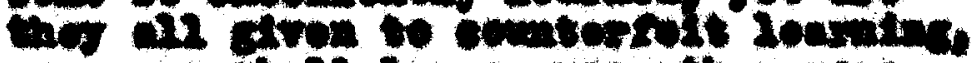

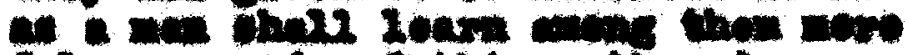

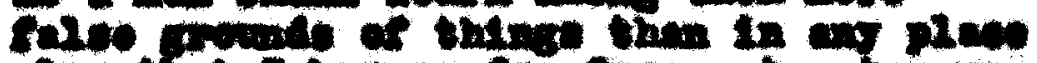

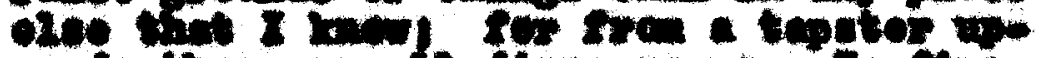

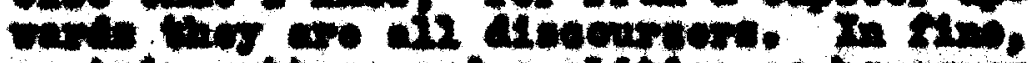

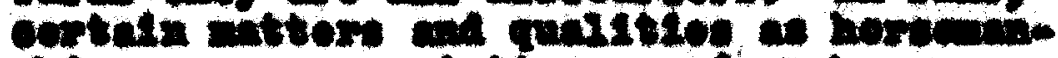

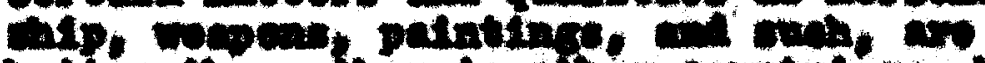

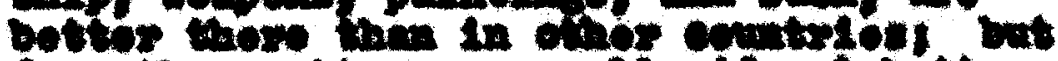

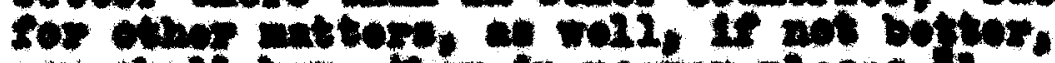

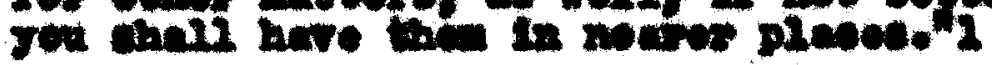

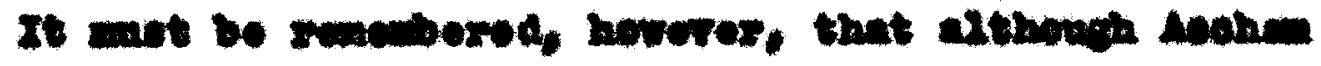

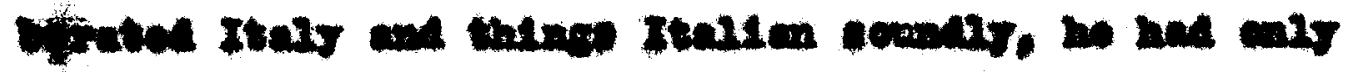

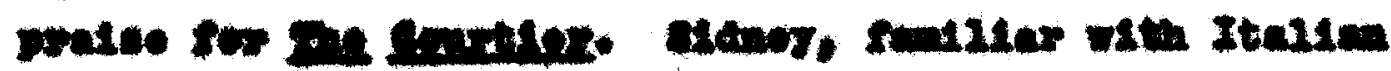

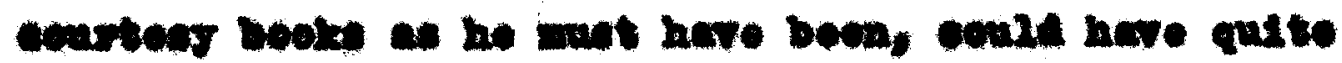

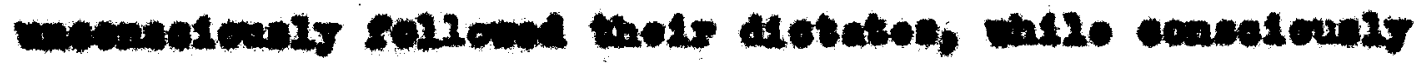

2 Rown. p. 204 


$$
-\infty
$$

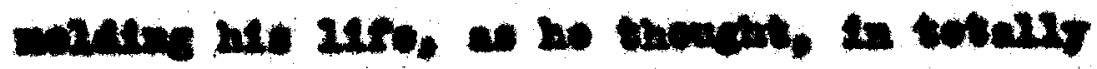

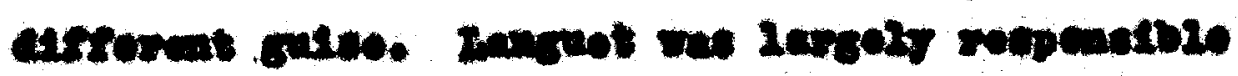

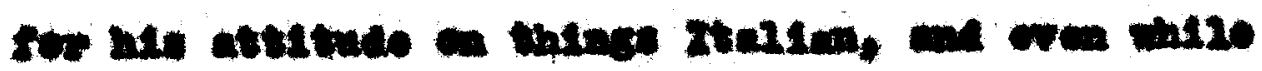

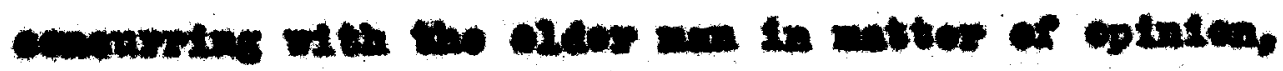

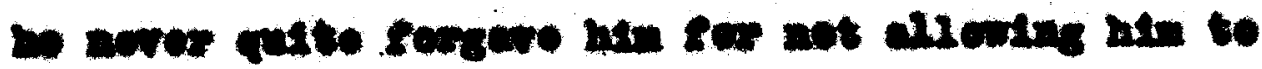
vast smos.

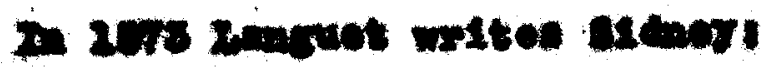

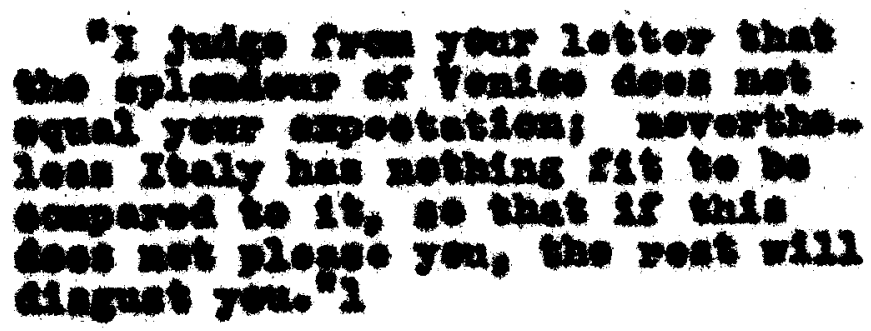

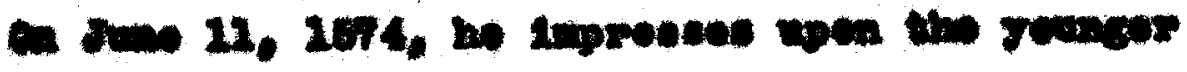

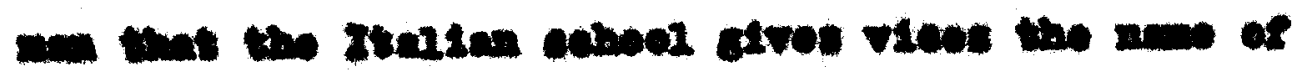
perveces, is

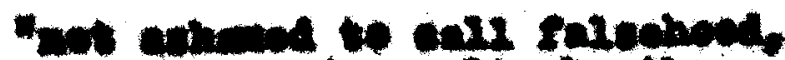

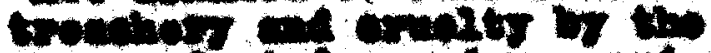

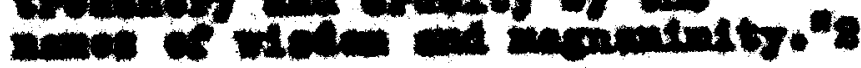

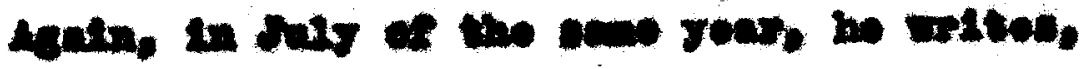

How 1eptos. in mich jou

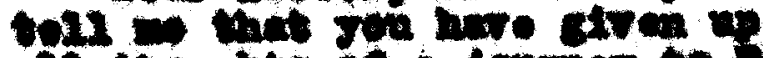

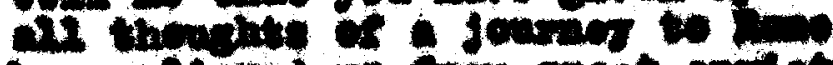

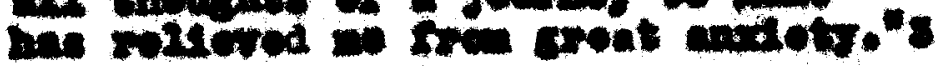

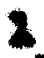

Poare, p. 28.

8

214. p. re.

nAc. D. 86.
} 


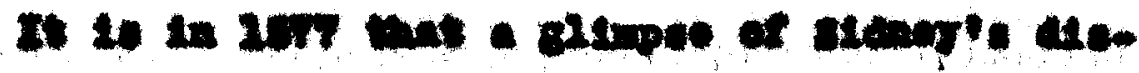

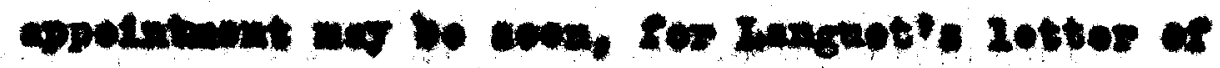
210 24 ronile

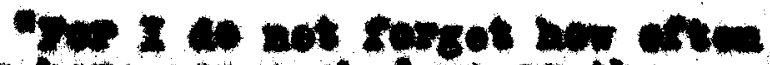

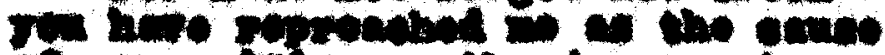
araf exthe of the jawier to $+\log _{2}$

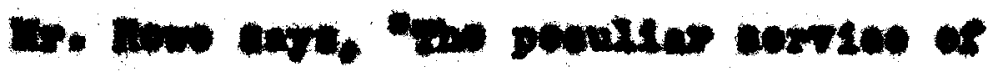

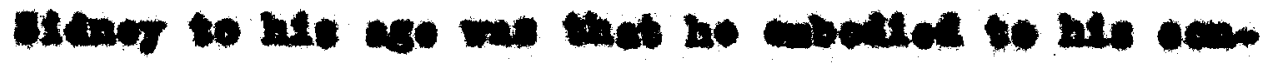

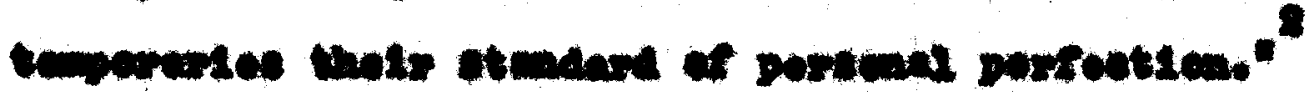

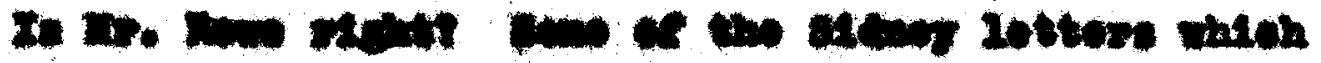

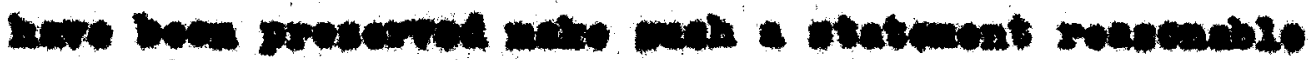

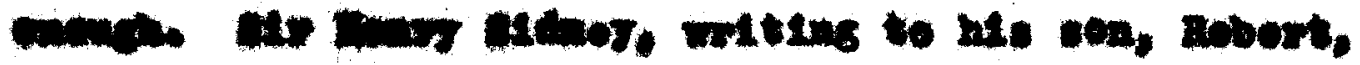

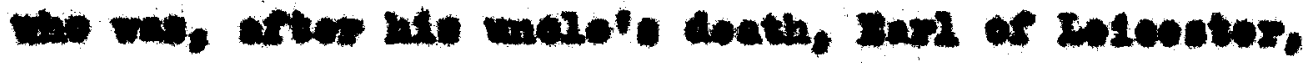
ancin

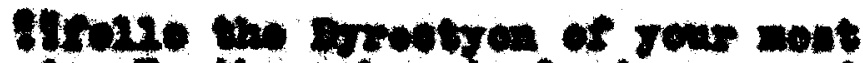

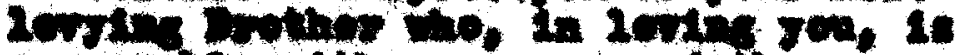

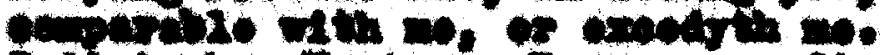

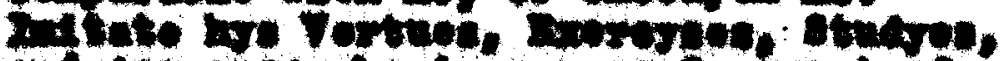

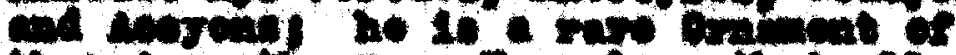

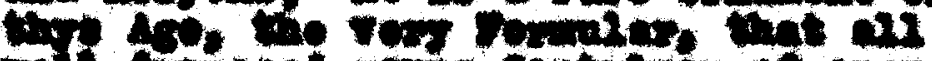

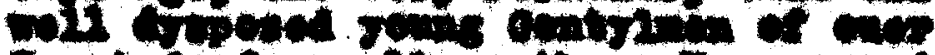

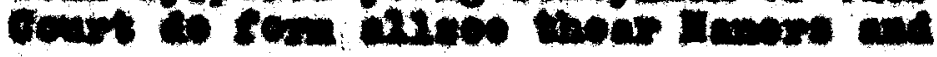

2

7vace, D. 101 8 Inimino Do 3 . 


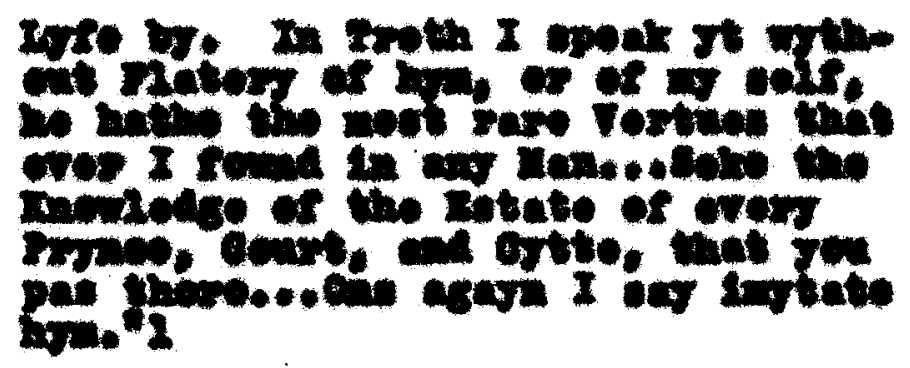

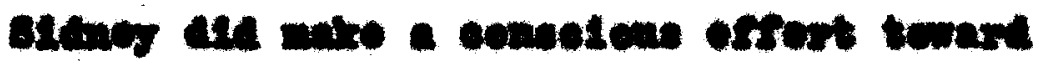

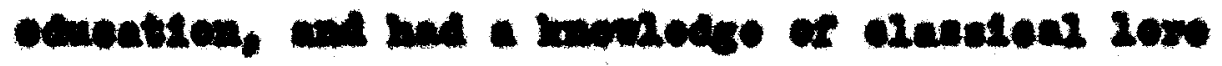

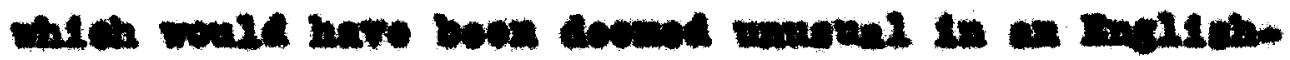

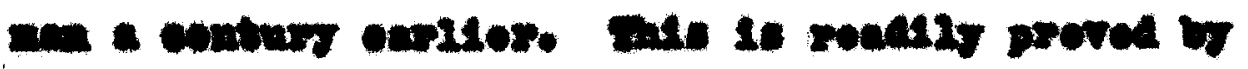

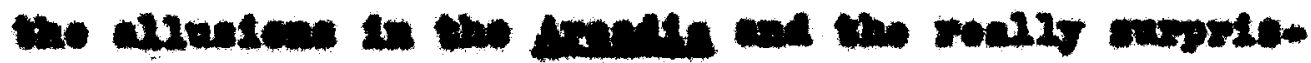

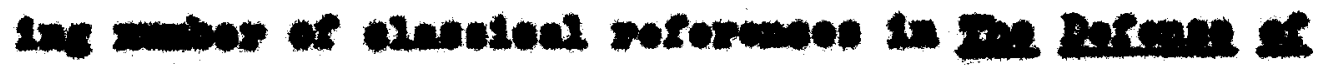

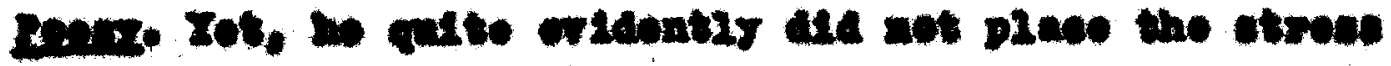

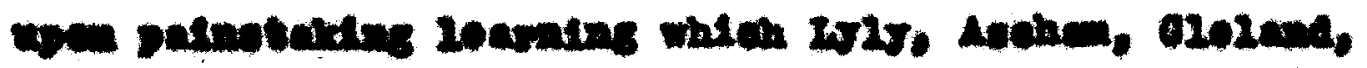

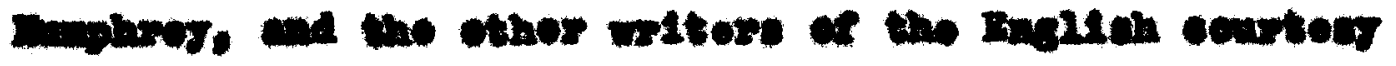

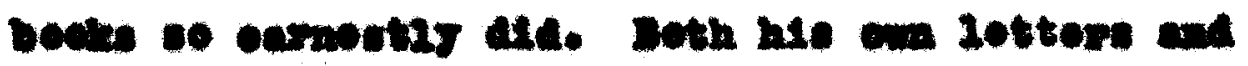

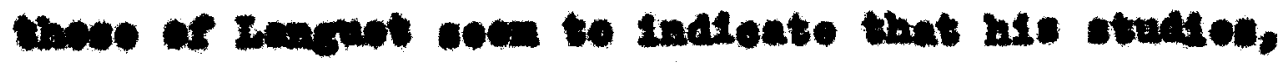

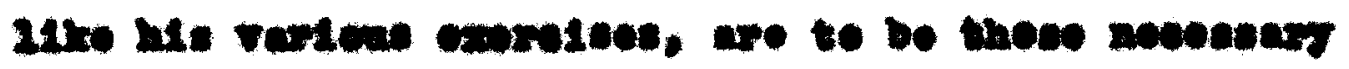

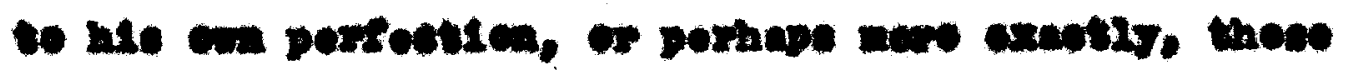

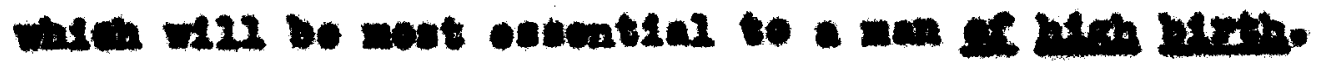

2

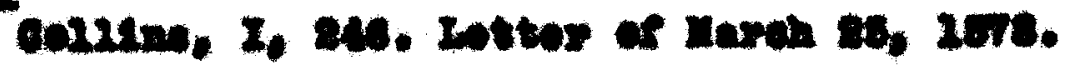




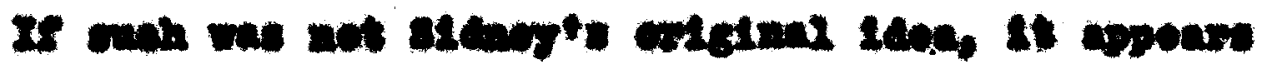

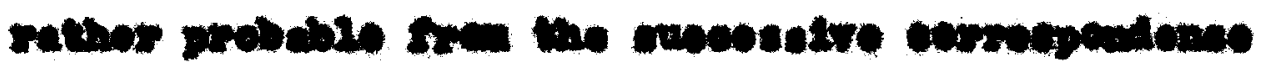

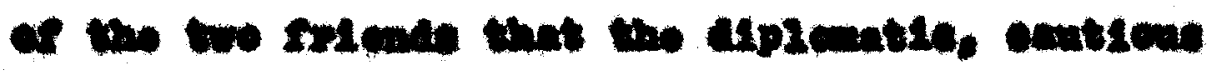

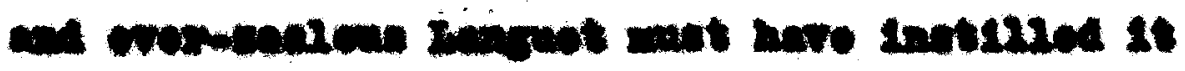

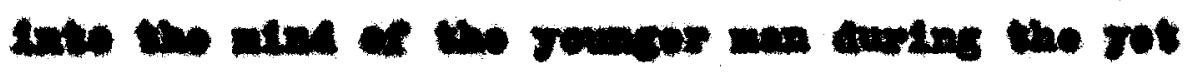

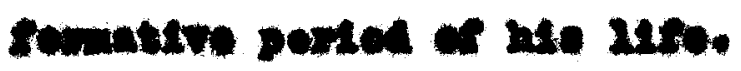

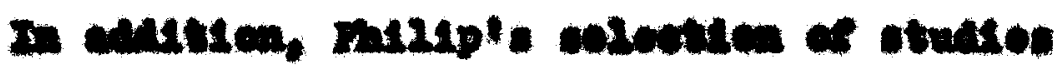

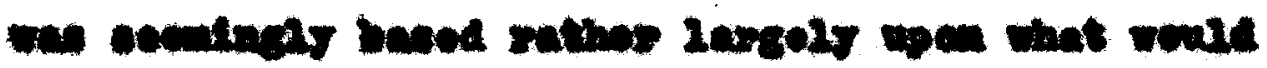

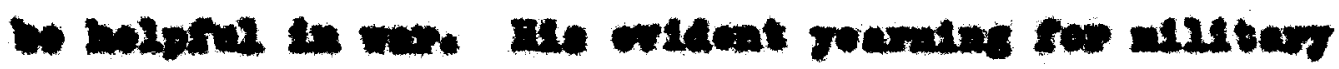

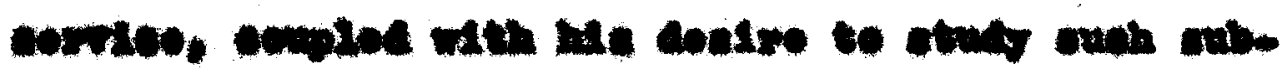

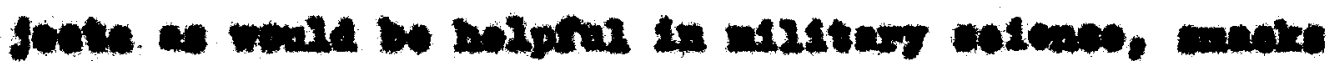

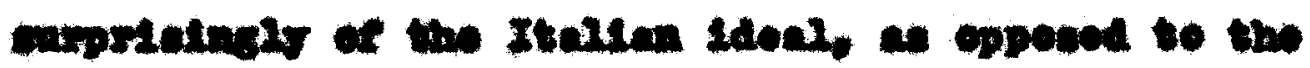

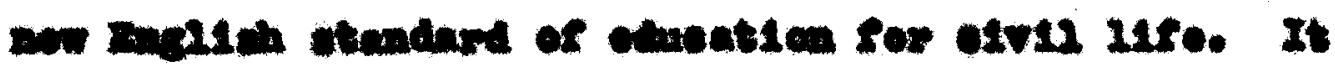

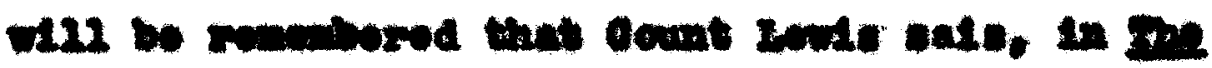
$2 x+10 x$

$$
\begin{aligned}
& \text { Had thene tre potnts (3ourdin }
\end{aligned}
$$

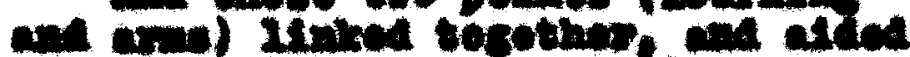

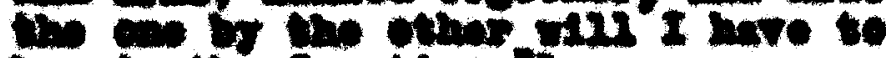

$$
\begin{aligned}
& \text { we in in andior. }
\end{aligned}
$$

2

etrigums, 78 
A Ren exoospte free the 20ttore of

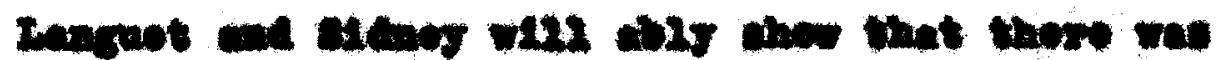

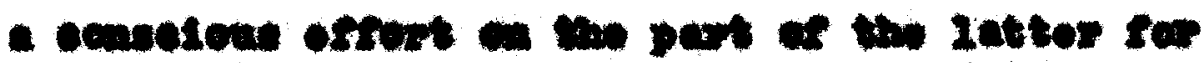

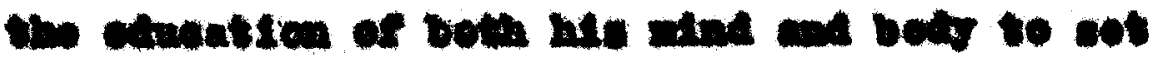

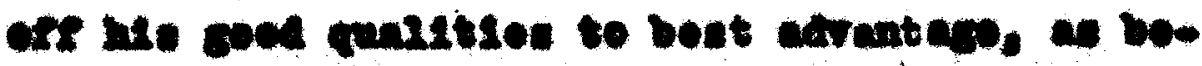

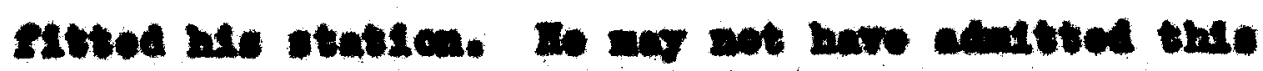

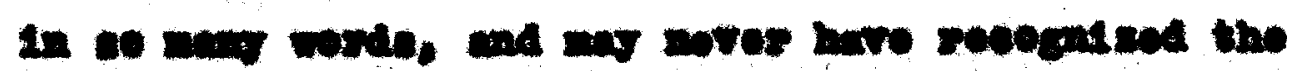

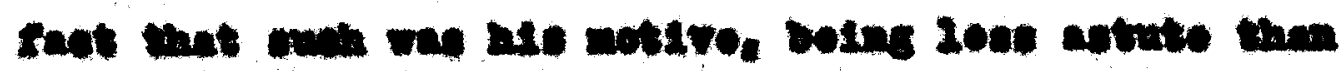

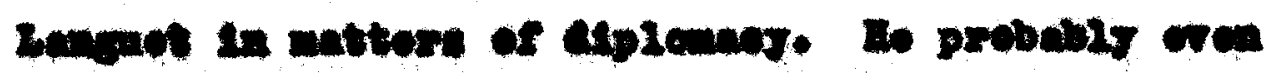

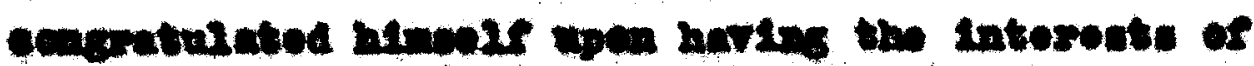

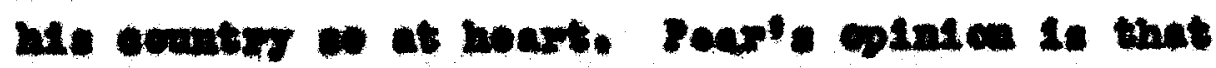

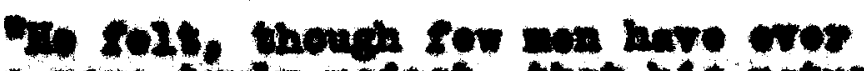

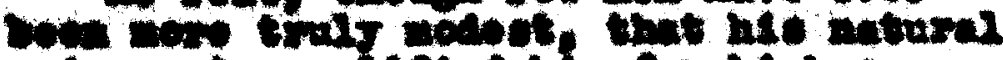

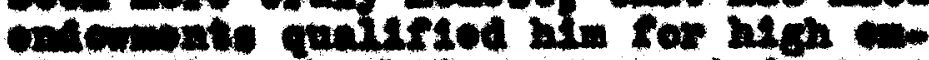

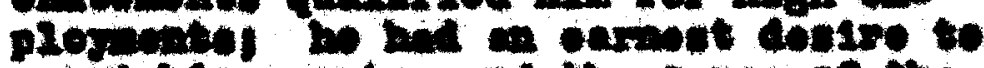

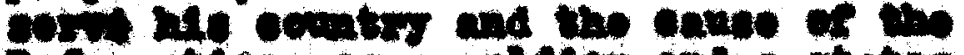

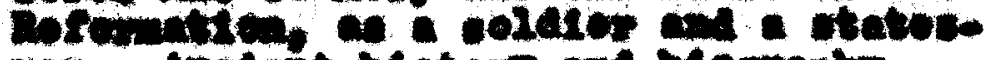

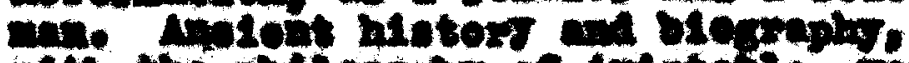

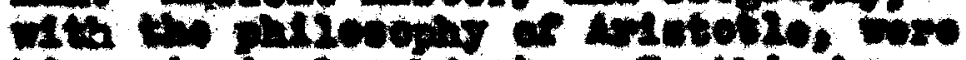

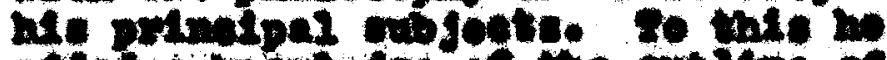

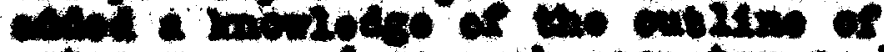

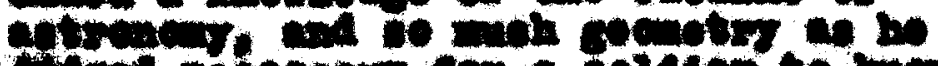

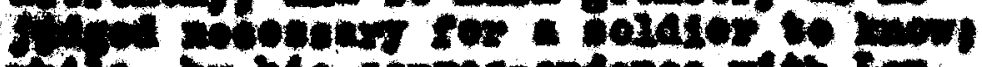

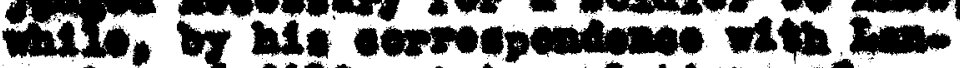

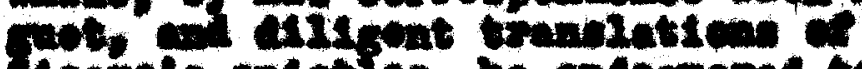

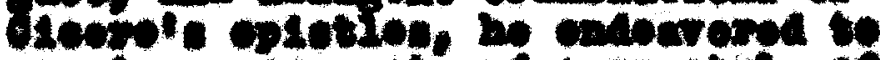

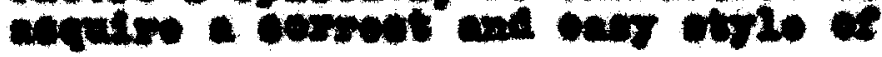


2otove matemen

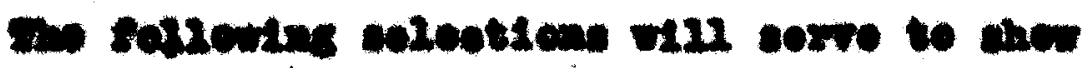

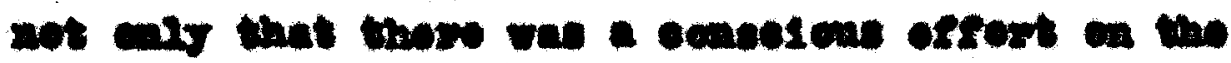

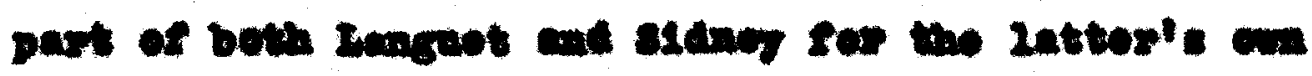

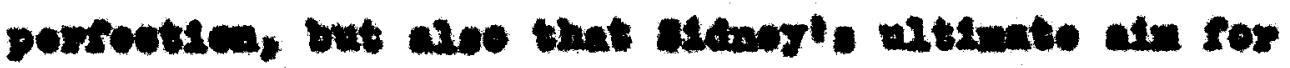

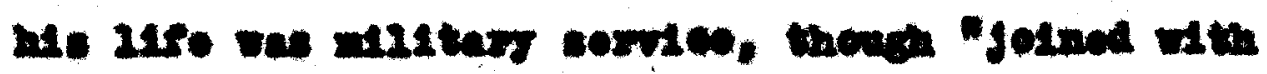
2oarang.

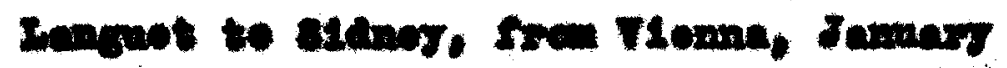
a. $2 \pi 14$
I Inew not wether it is woe to

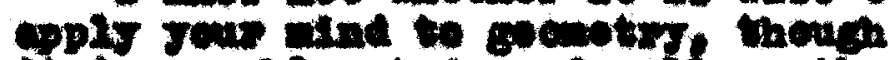

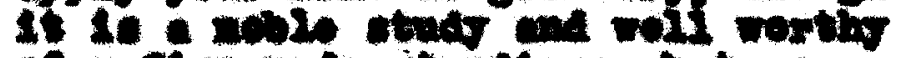

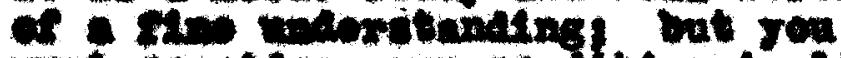 mot center 7 ond enden in 2is.

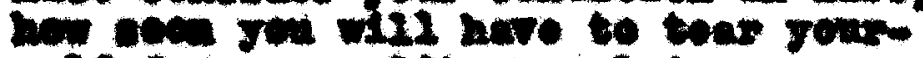

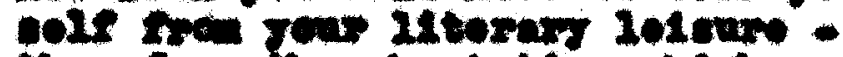

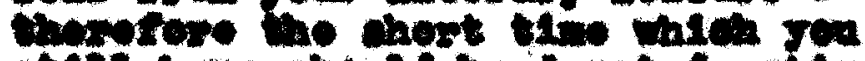

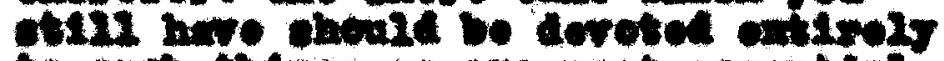 to on thing en aro moot opontin.

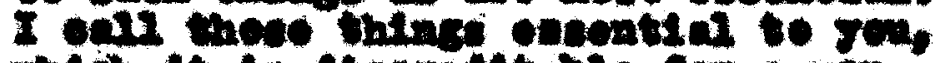 wich is is aleorotitablo for a mo a hich birth not to ber. an whit

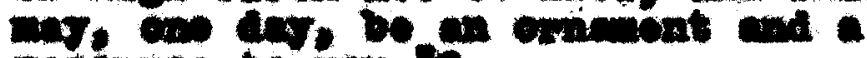

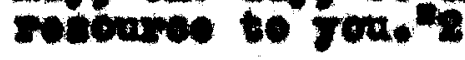

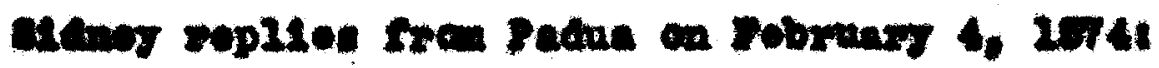

1

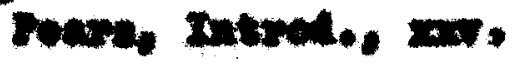

8

Pours, p. 88. 


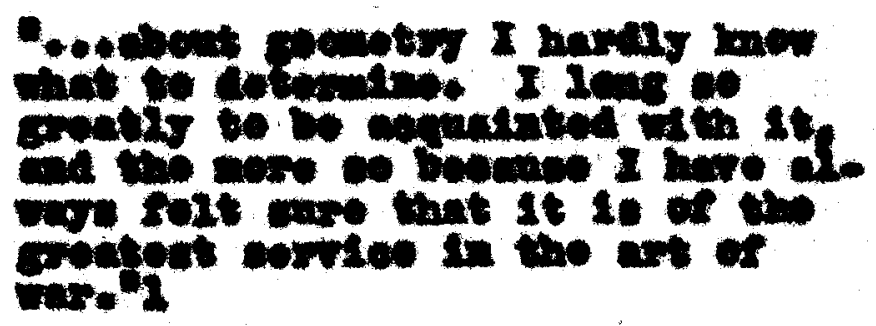

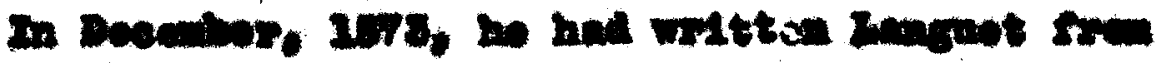

Voneses

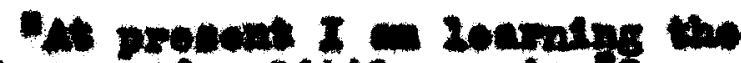

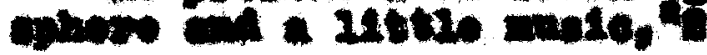

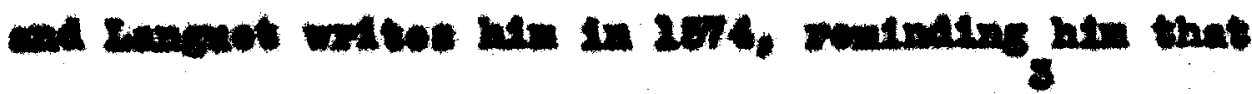

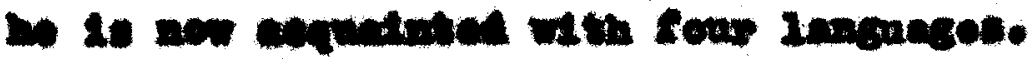

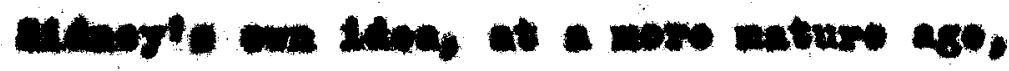

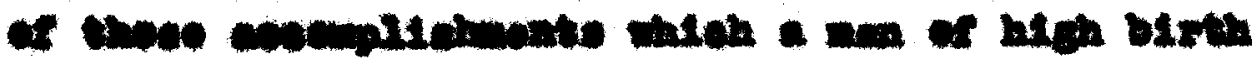

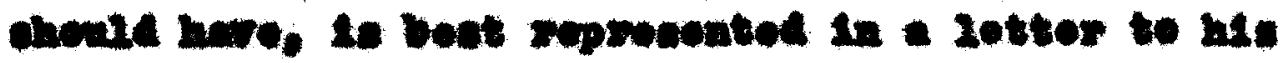

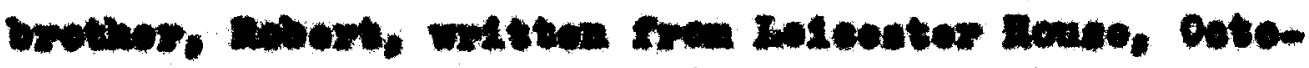
bow 10, 21001

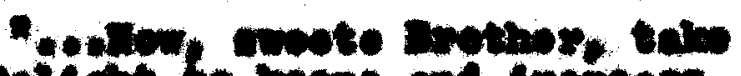

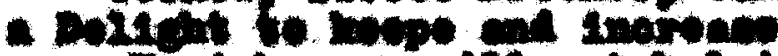

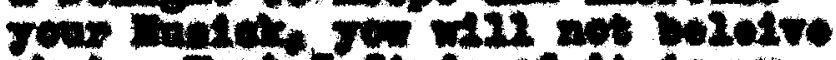
Jat a 2 stan of it in 5

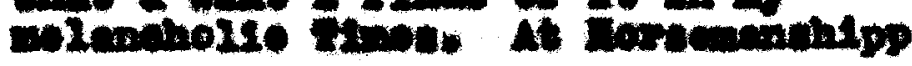

2

noum. p. 26. 8 INt Do 0. Mite pe 80 


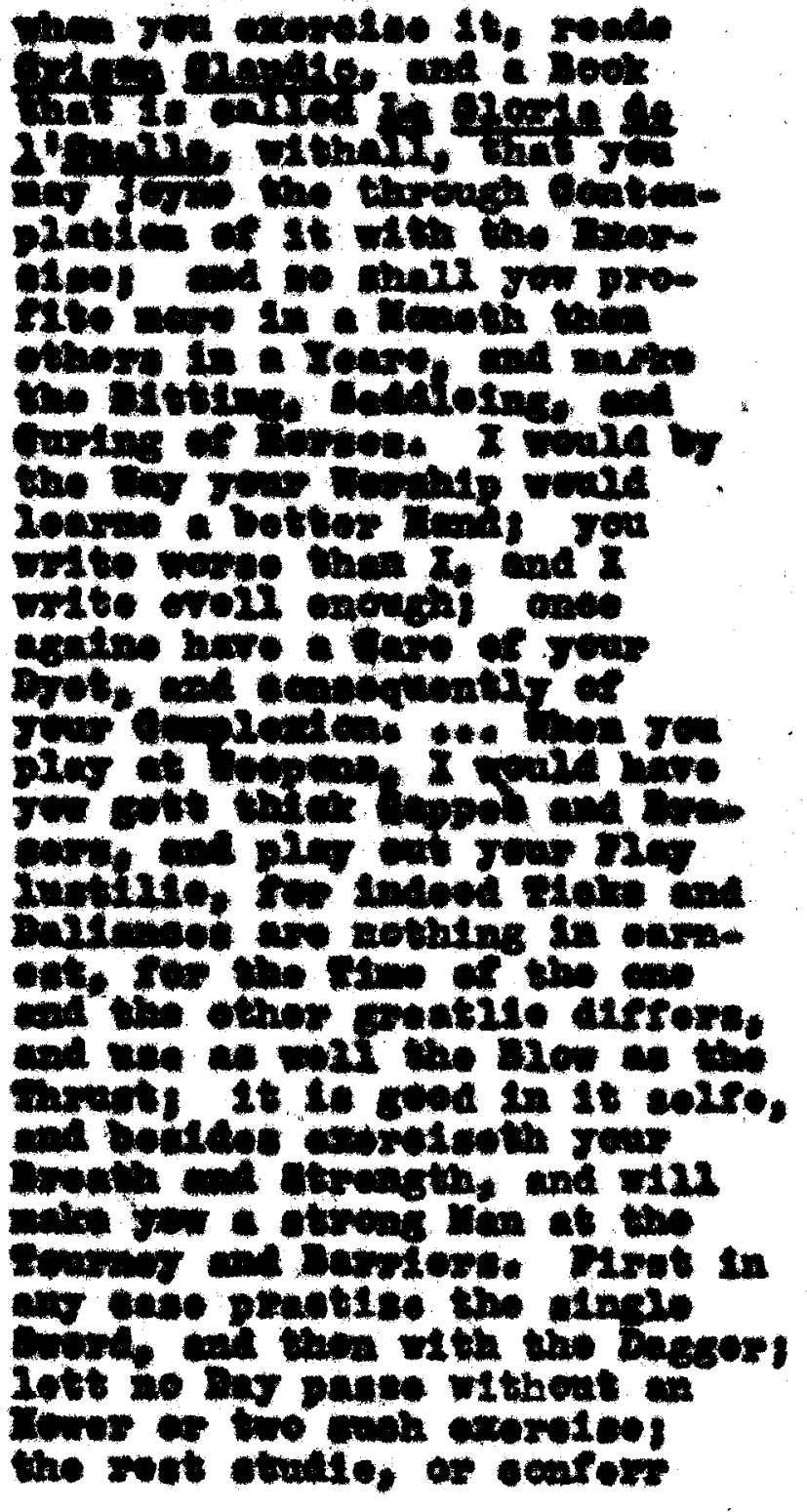


A11gent110, and to brall gon cons keas to $=$ oen ert and oroustom

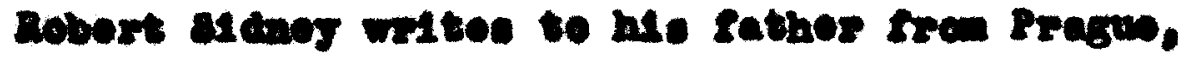

Dovember 1, in this roar, an followes

Wy brothor 21kowd in his lottor te Inery inite, wrote that if thore wore sny geed Inren. I honld $8 \circ$ to thom, but It jot I have hare of none."

Innguet ald not orpathise with sidneg's

dosire to do corries in a forelgn was whon thore was Do oall for suoh aotion. In Iny, 2078, ho mxtest

".obut moot won of high birth ase possesued with this mainees. that ther loag after a roputation founded on bloodshod, and bolleve that there is no glory for thom exoopt thet which 10 connoetred with the dostruetion of mankind. Ought not jou, edorned as jou are by fro. Videneo, with all those oplondid cirte af the aind, to reel otherwico than mon foel, no are burled in the nont profound chades of lgeoranoe.

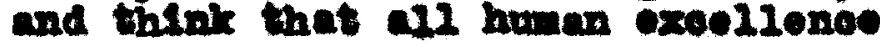

2 Col11n, I, 885-88B. 8 Feare, Yootzote, p. 171. 


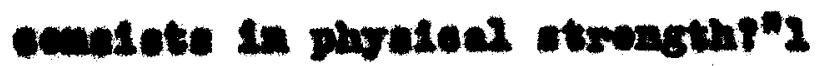

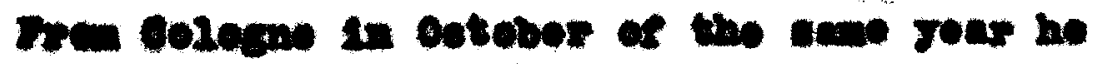
ecotn wattont

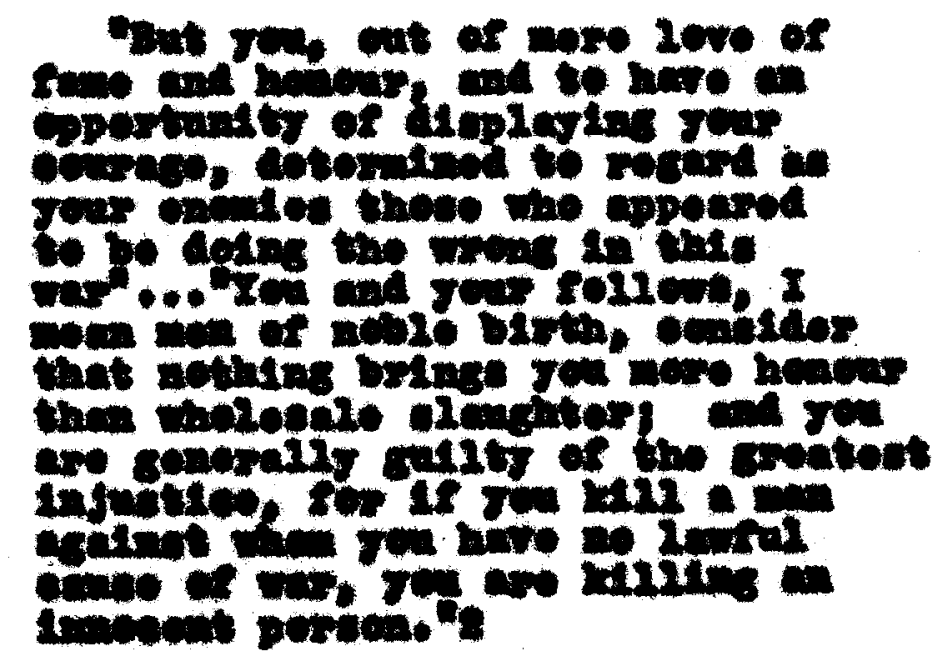

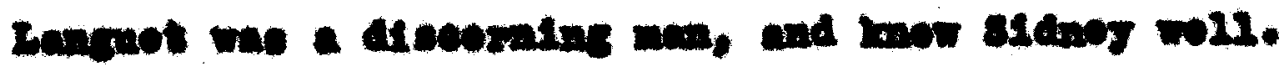

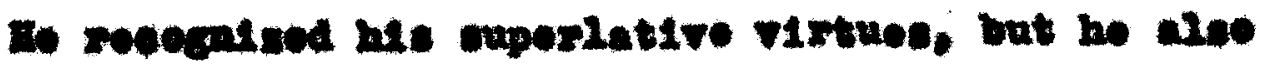

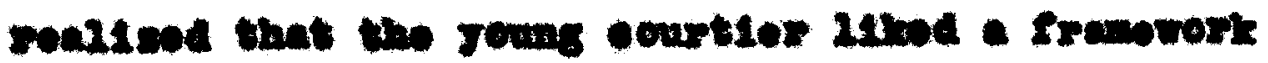

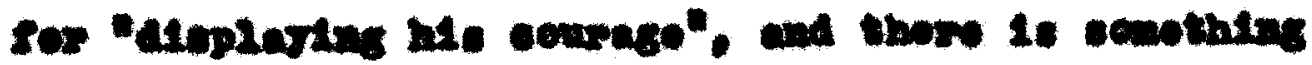

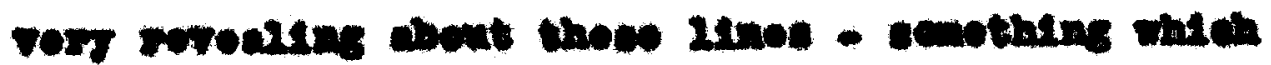

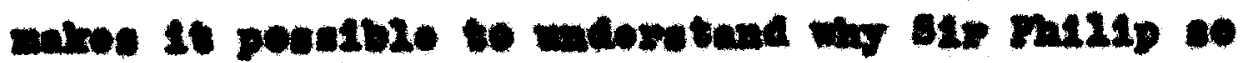

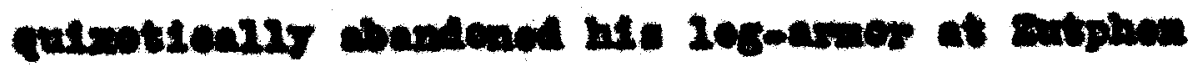

$$
\begin{aligned}
& 2 \\
& \text { Poara, D. } 14 . \\
& 2 \\
& \text { Mno po 284. }
\end{aligned}
$$




$$
+74
$$

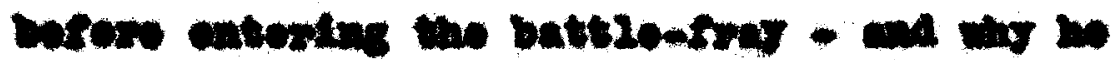
morued be en of wates.

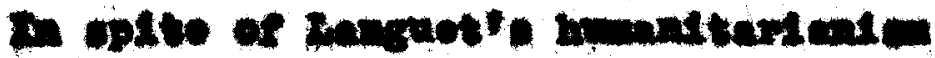

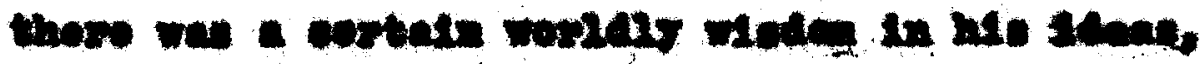

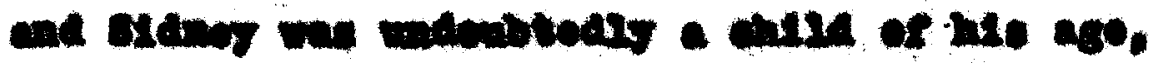

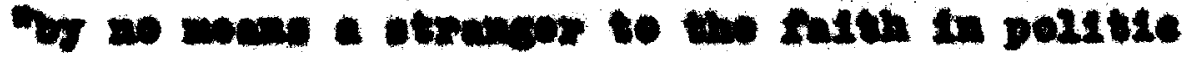

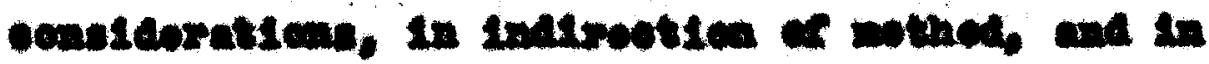

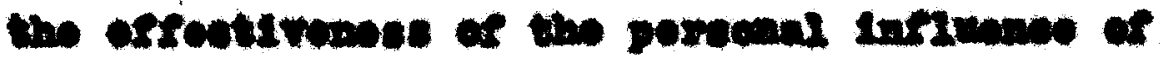

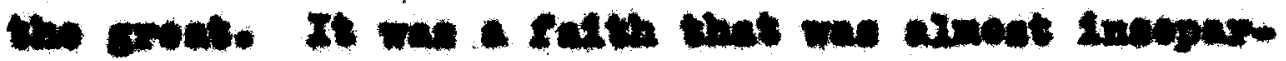

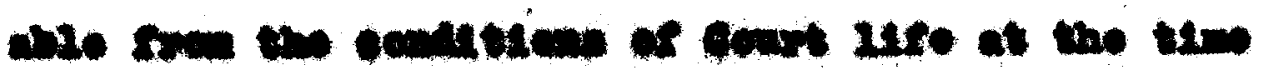

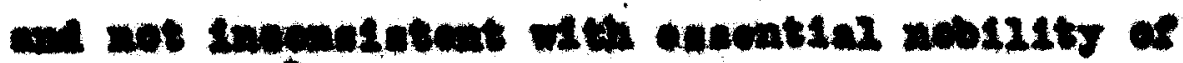

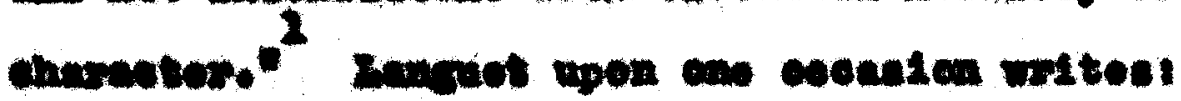

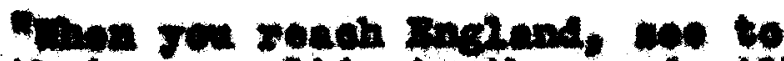
1t that rea coltivate the cooumill

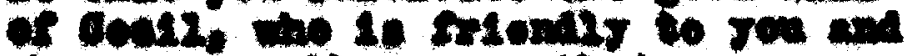

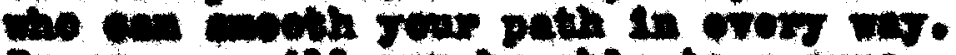

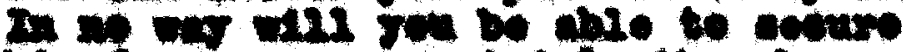
Me repos nowe cortatint than by you

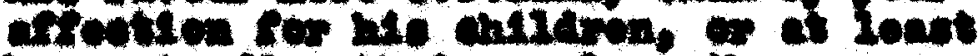

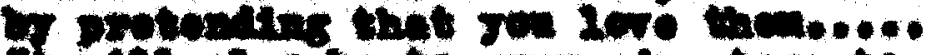
II 111 a 190 be to Jour edrantace to

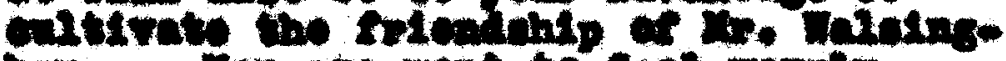

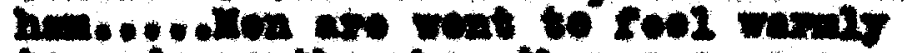
servarde jouthe mo, thos $60 \%, 60$

2 maxe. 24. 
coping tat the eatoty of the

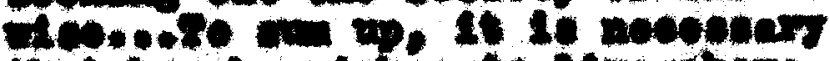

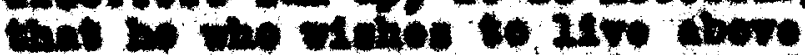

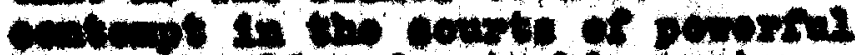

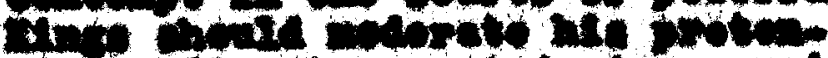

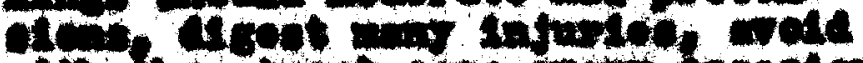

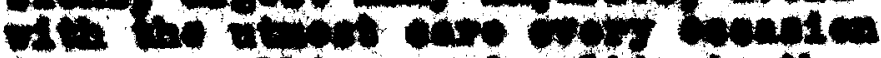

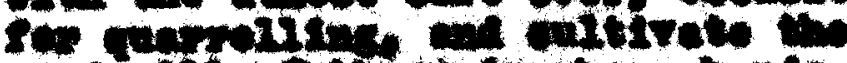

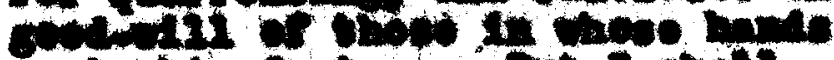

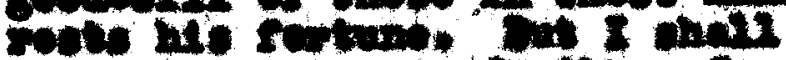

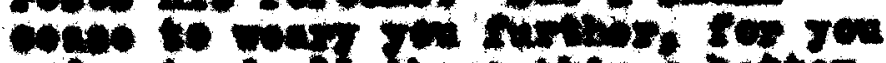

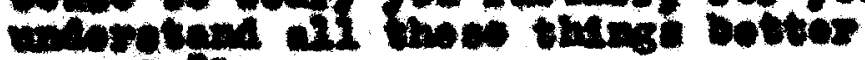
than 8.2

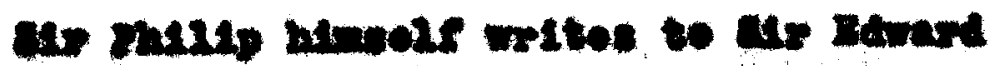

stactors in 2004.

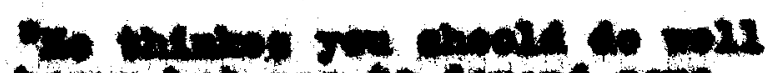

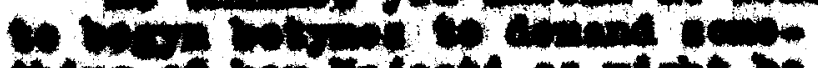

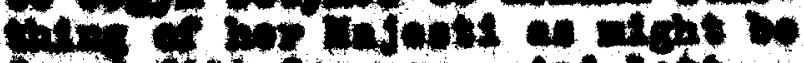

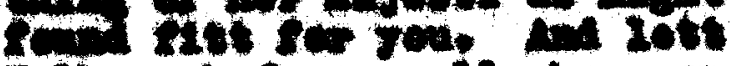

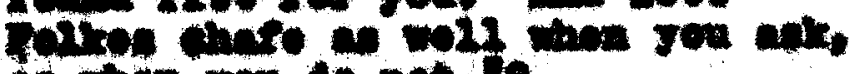

A trin rou do not.t.

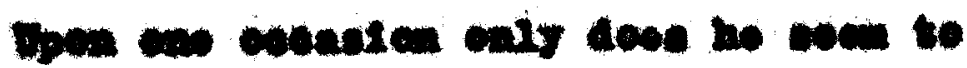

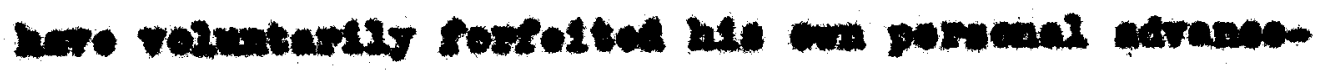

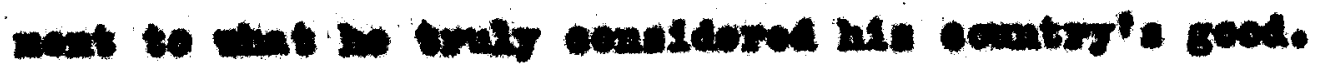

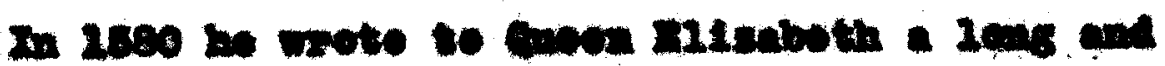

2

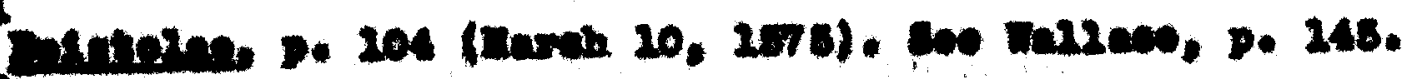
exrune, $x_{0}$, pe ape. 


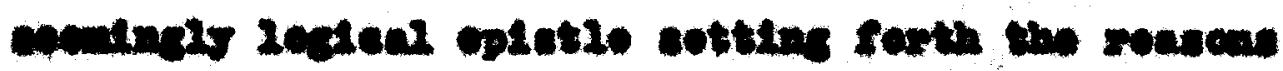

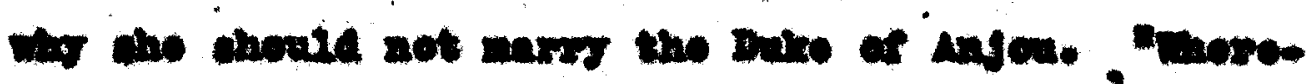

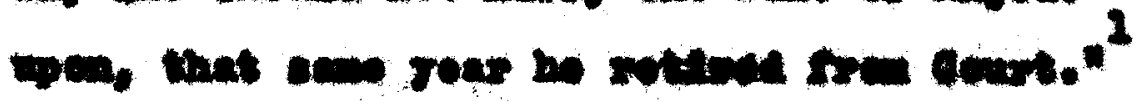

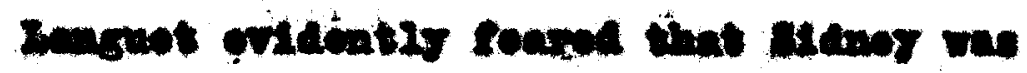

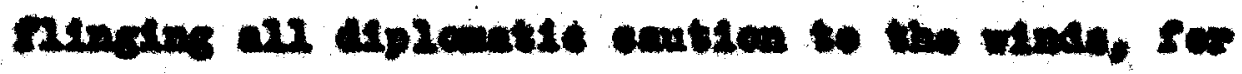

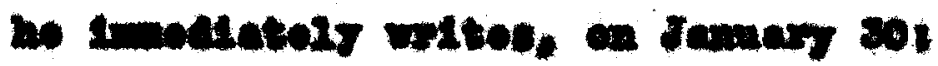

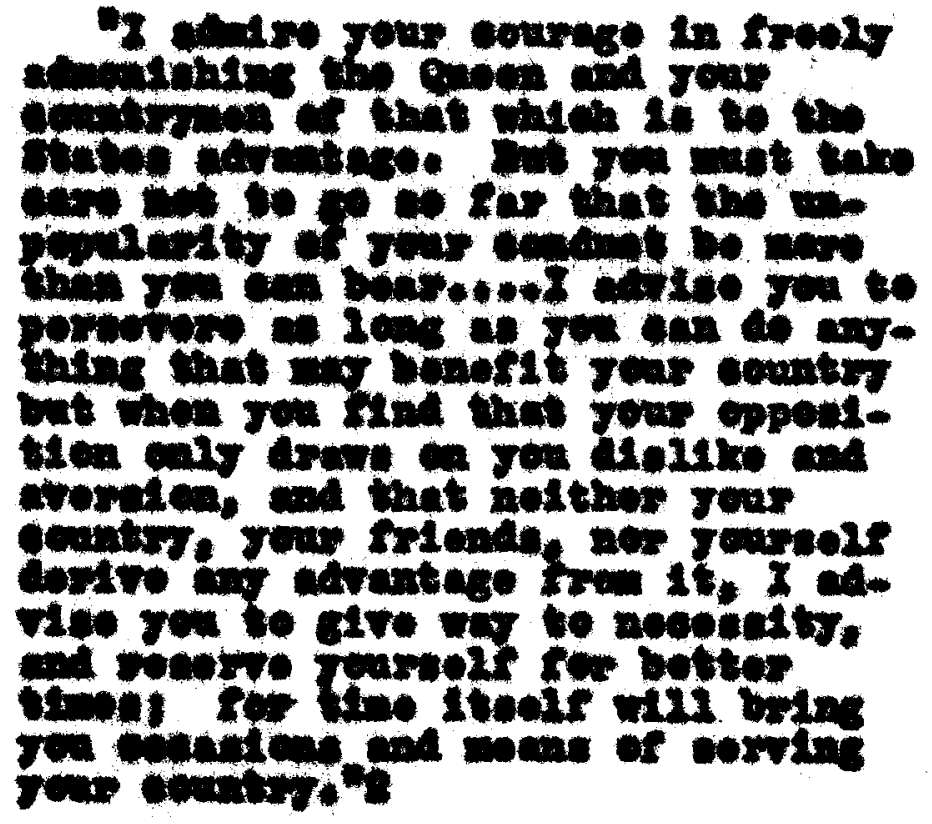

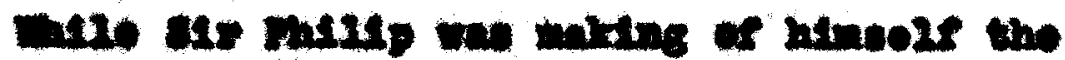

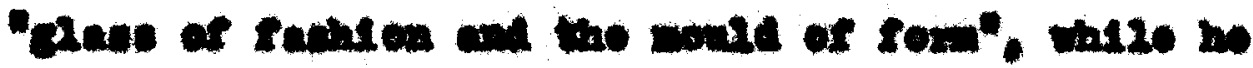

$\mathbf{2}$

anting, $x, 208$

8

Sound, D. 170 . 


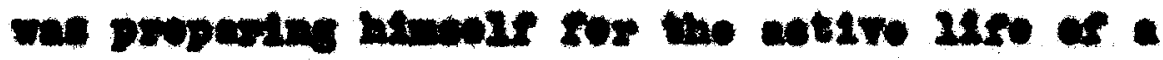
sortion, wo was, to the porware plen or fate.

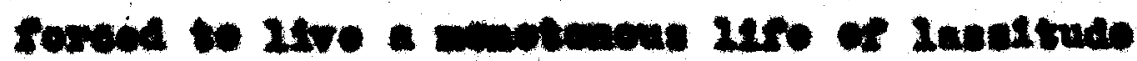

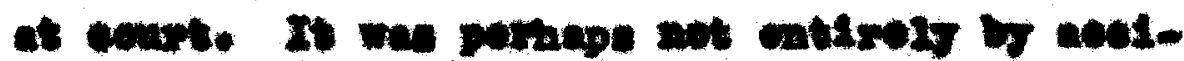

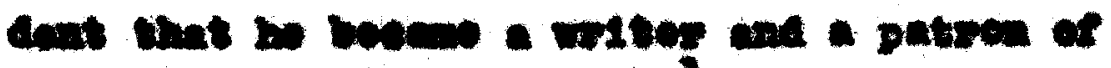

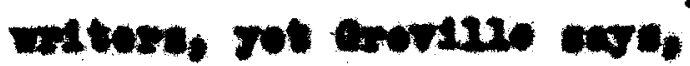

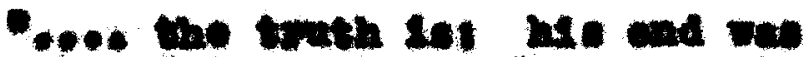

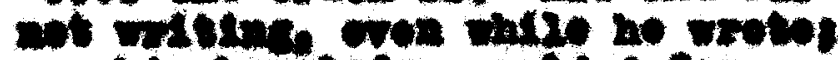

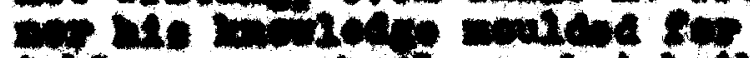

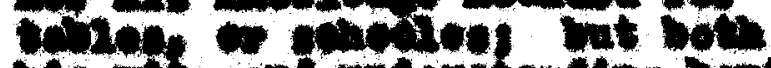

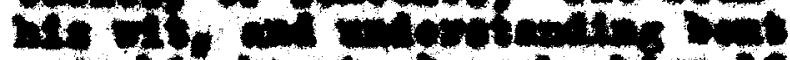

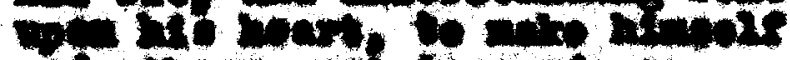

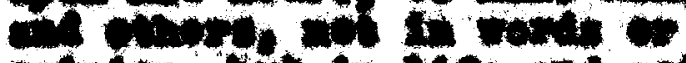

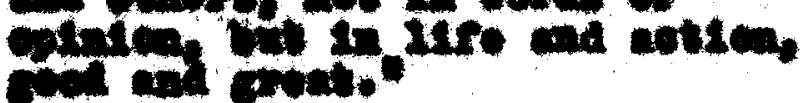

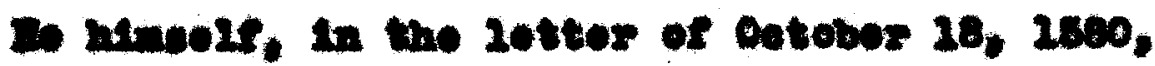
te his botwor, ano,

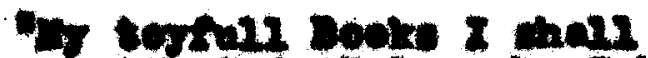

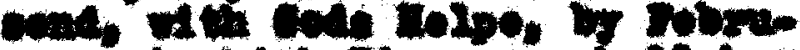

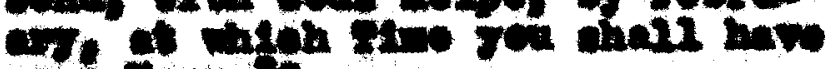
roch nowis?

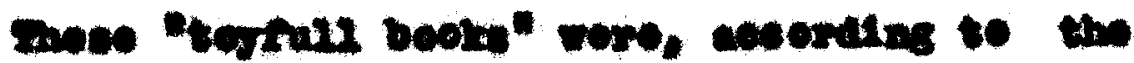

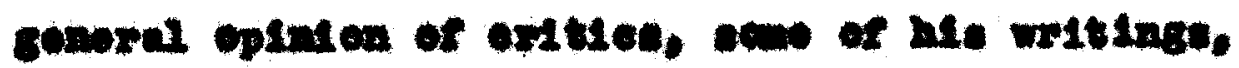
3

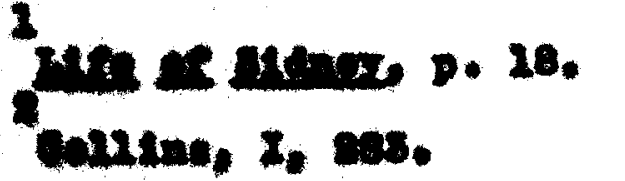




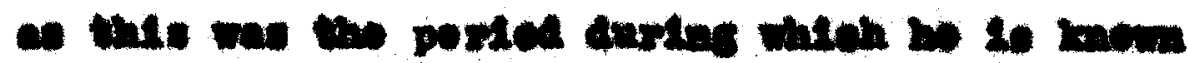

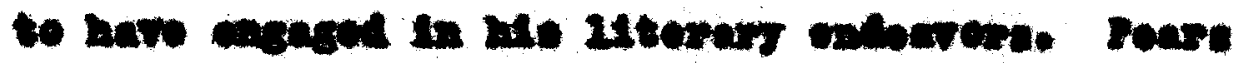

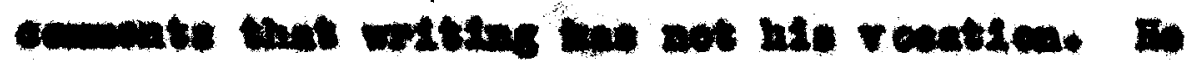

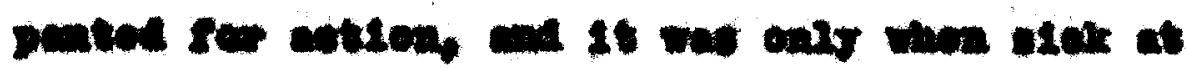

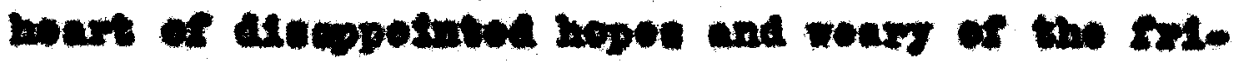

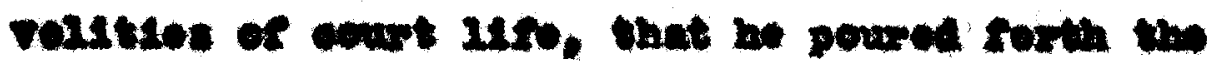

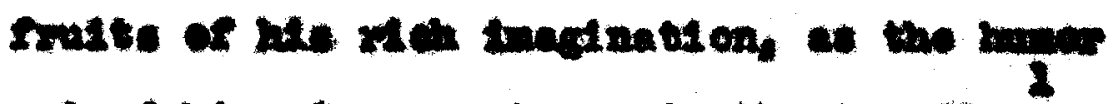

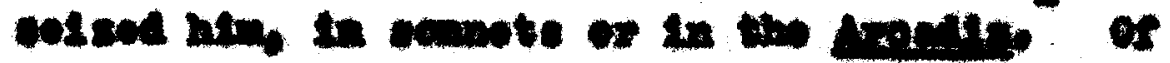

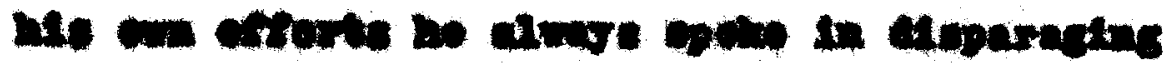

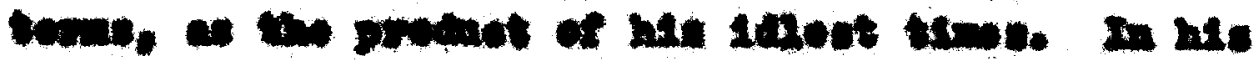

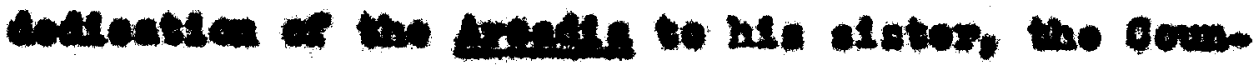

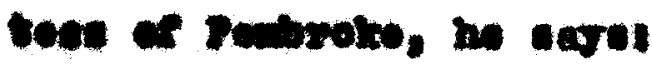

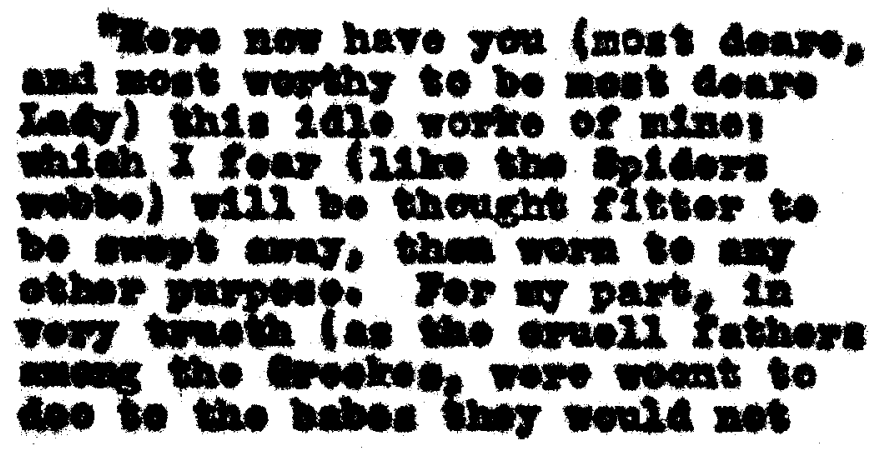

2

Boure, Intwod, Irate. 
sootor) I conld wil rand in w have, to cant out in eom dobert

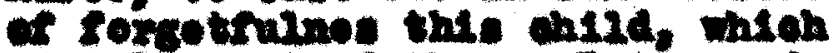
I I I ate to fathor. But jen aot. 12we wo too 1t, and your doalm, to a hart is en ebeolute comandonoti. Iom. It 14 done molie for 7ow, melt se jous if jou keope it te joug solfo, or to oush friemien. whe 121 molgh orwere in the balatice. of geod w1I, I hope, for the sathore eake. It w12 be parbond, posthanes ande mon of, though in it belfe is

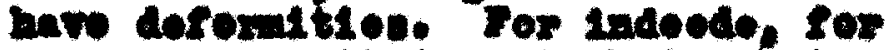
coverer wee 1 t is not, bolng but a trine, and that triningle hamed.

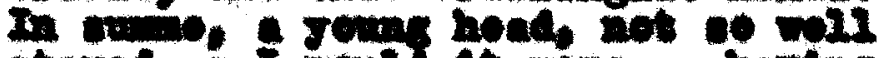

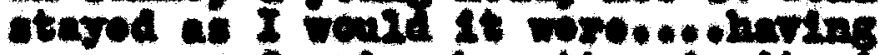
gray nang fanke bogotion in 16, If 1. had nos bon in seas way colifored, would have expen a nonpter, and mone gowse ulght I bo that ther eans in. thon that thor gat out." 1

stenes ariom nothing that he wete

to be publinhod curing his zefotins, and oven

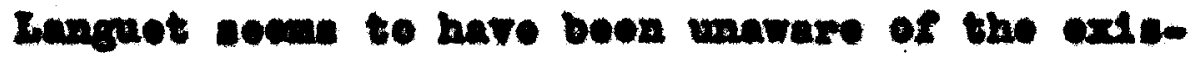
tones of the Axrelses sor no montion is made of 1t In the extant 2otters. To be sure, he did "elsp Into the tit2o of a poot". to quote he

$\mathbf{2}$

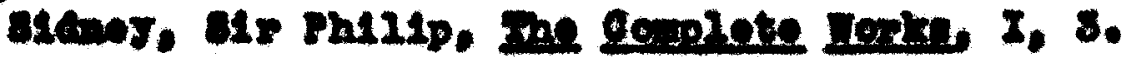




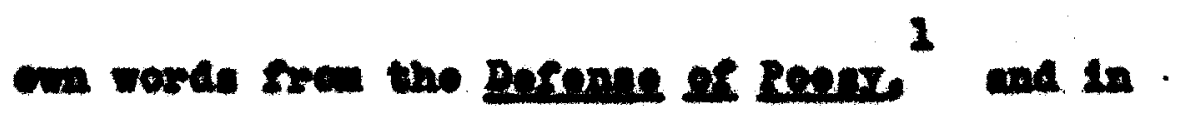
clates on had a place of himeole anong Blisubothen patreas. Aubres saja.

"ro wan of a vors manteleon oplet, and 2lberall to ail 10vers of Ioefralins, and to those thet prom. tonded to eng esqualntanes with Pow nackes in be miden that he wa cloge and our foited ith the peotattore of those ange."n

Evon 00, it sceme that sidnog's mbition was oror

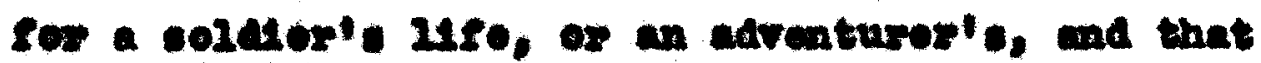
his Iftorary puroults wore in reality but a 100phole of enempe from the nonotencas life of the cowrt. Ite plene for accoupanging Drake on his oxm polles ca, and he cubsequent disappointmont won bo val not porifted by the gaon to 80 , are rocounted 8

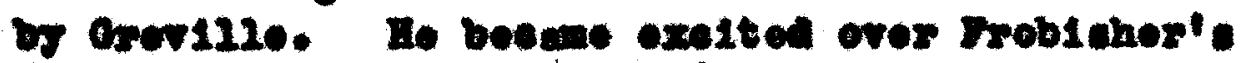
cupposed alcecvery of gold, and would doubtions

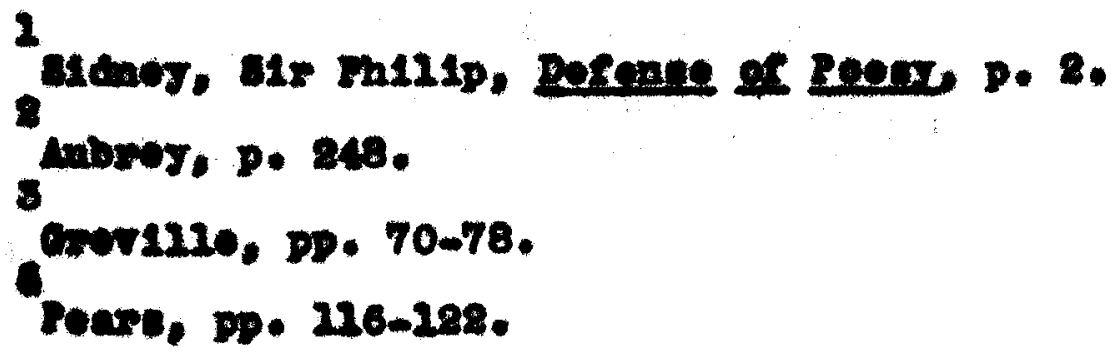




$$
\therefore-1-
$$

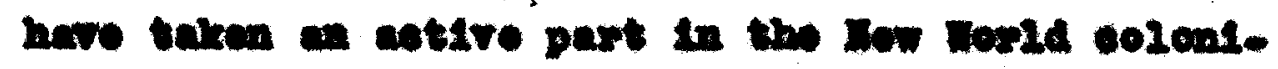
satien if to cowld over have wo buseboth' approved.

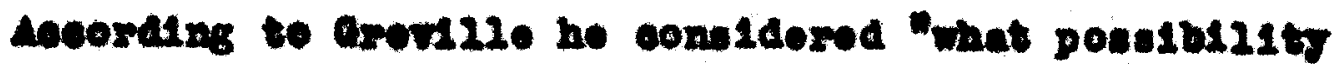
thore wa for hin. that had no dolight to seat 198 at hemo, of roproponaling sene othor forrati onter. prise. probable and It to Invite that swellent

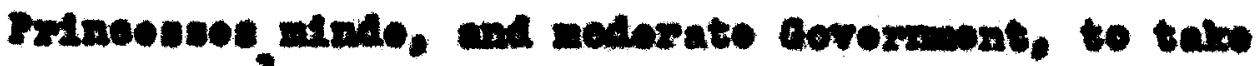
nola ext. $0^{2}$

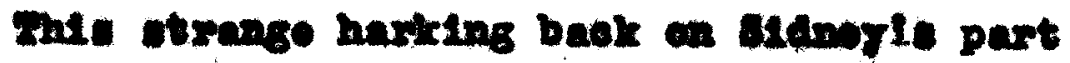

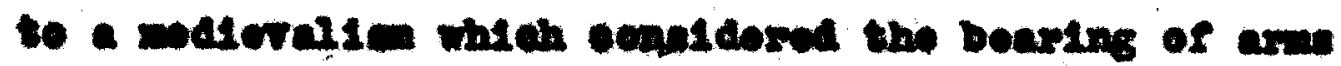

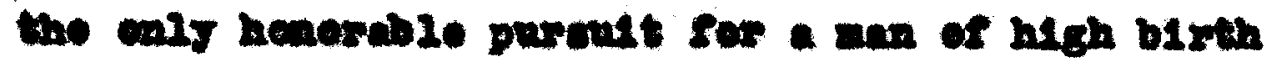

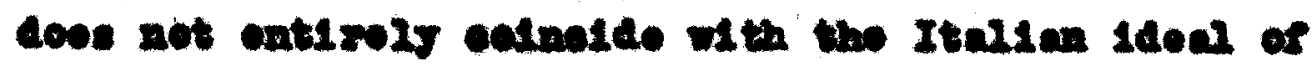
the porfot ecurtion. for the lattor wa to do sorvice

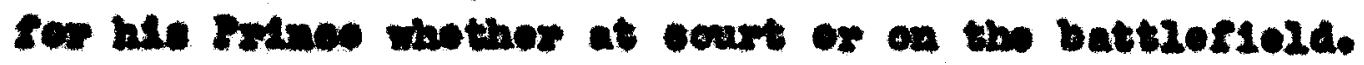

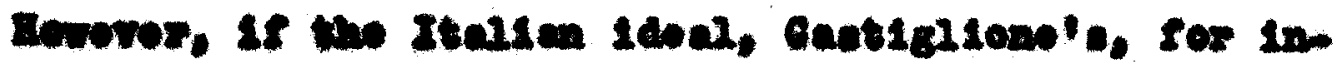

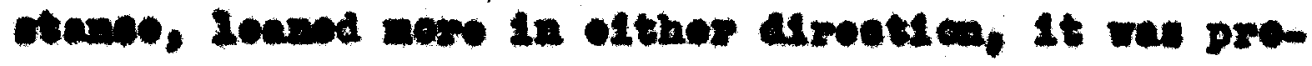

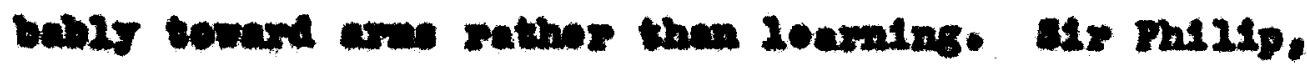

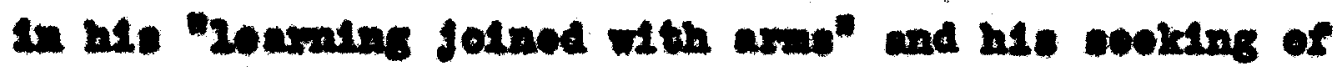

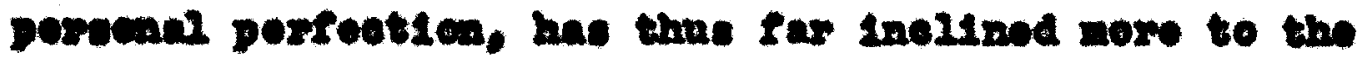

8 Cond210. 8.78 
$-7$.

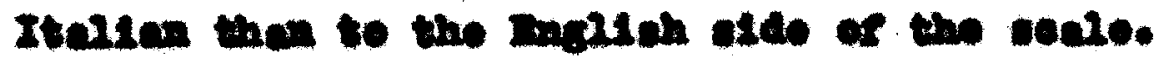
wes xoles, in serutation of this save that wor

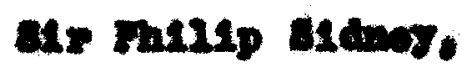

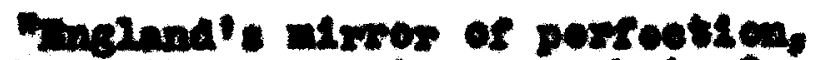

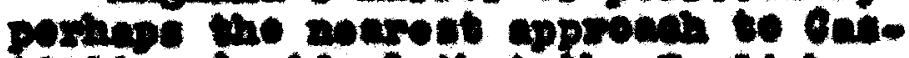

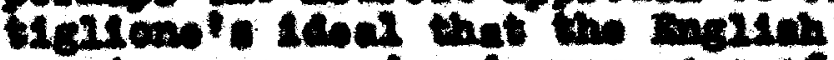
prediscomes producod, was wepe of

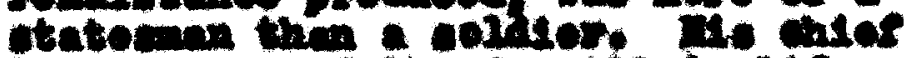

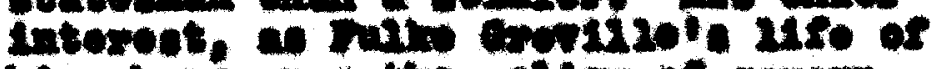

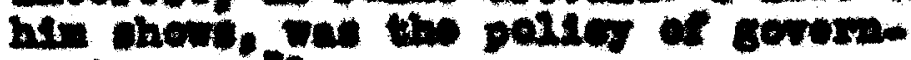
monten.......

Do eentimues,

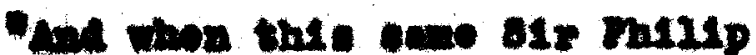 sleney seartwen reare Iater took

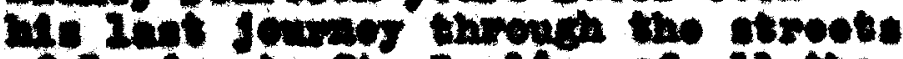

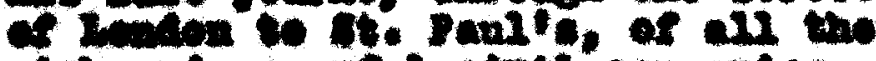

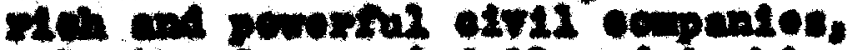

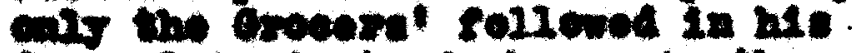 rumorel tratn to do homer to tho

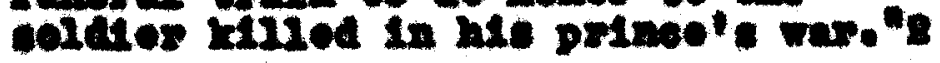

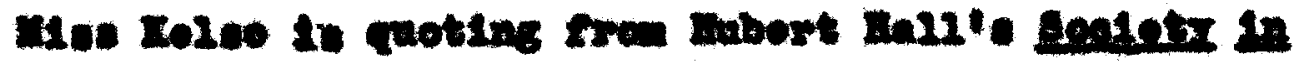

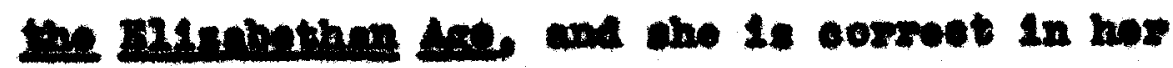

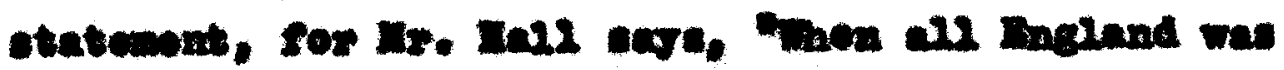

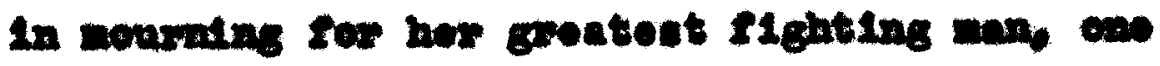
Alvie compeny only, the aroecsel, followed hla

\footnotetext{
1

20200, p. 4t.

219.. p. 4.
} 


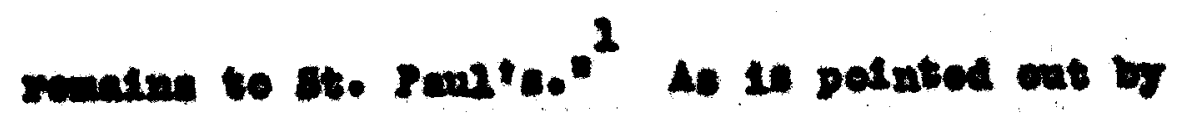

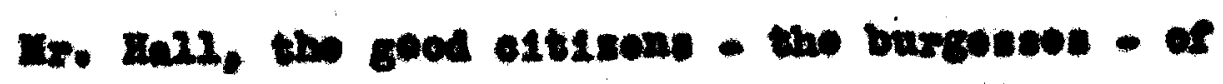

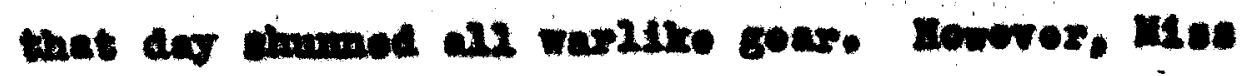
rel we dofoate her twe point that sideor was more

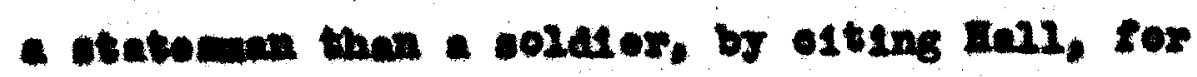

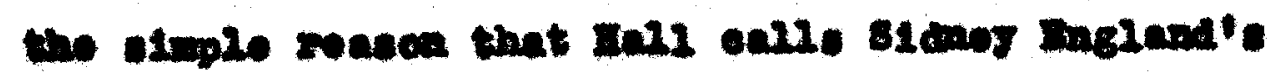

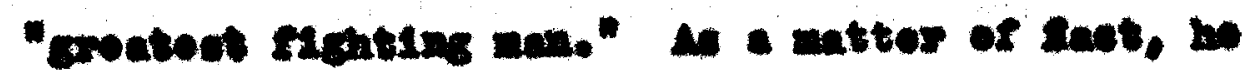

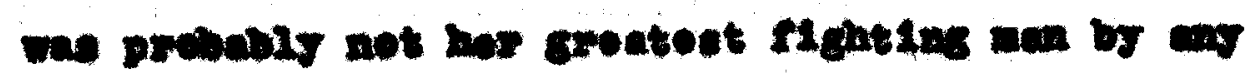

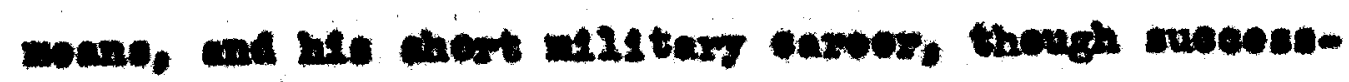

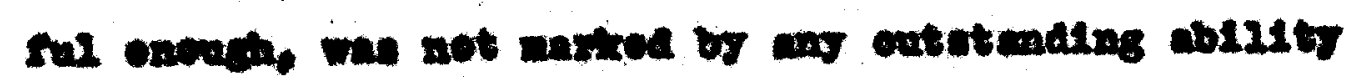
of the coldior. Zot, he shoald probably hare $14 k e d$

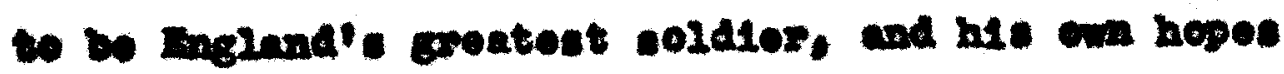

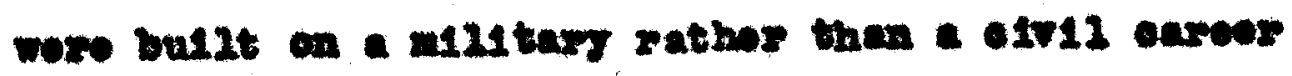
sor nineats.

In wat othos wage ate blanes oovingly eonfers to the aletates of the Itellen cearter

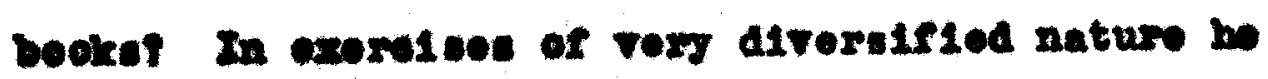

2 sontion pos. 


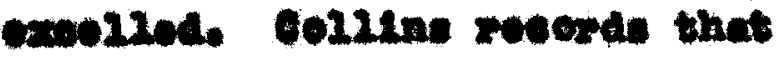

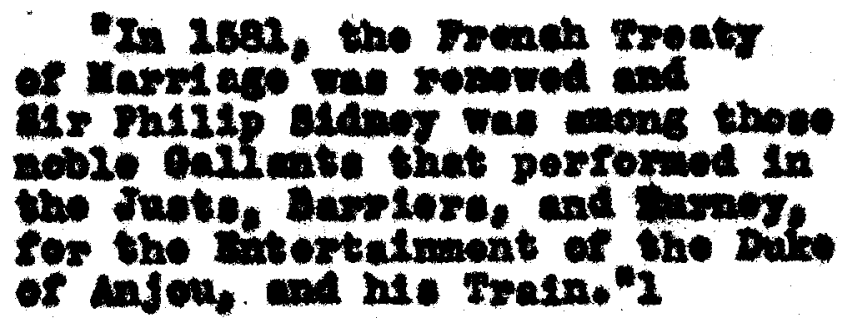

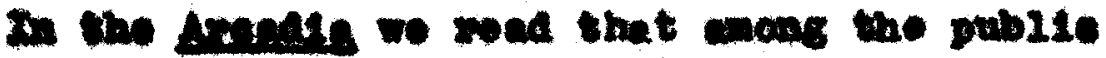

henoure which the lans and courtiore of morde

Ale to the croan oach joar,

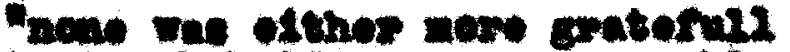

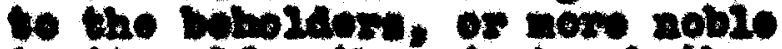

$$
\begin{aligned}
& \text { in It solfo, tho Junts. boh }
\end{aligned}
$$

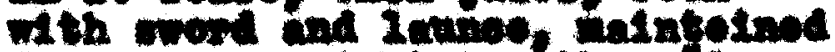

$$
\begin{aligned}
& \text { for a covernaticht sogothor. "s }
\end{aligned}
$$

It w212 be remebored that in his 2ettor to his

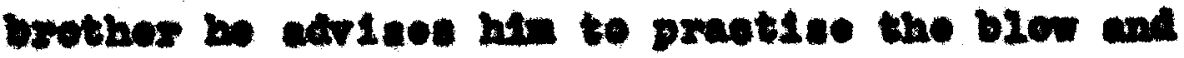

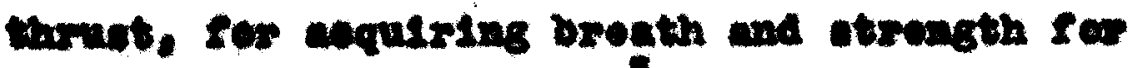
the seamer and barplore.

In the ane letter ho aleo cugseats twe namale en horosmanohlp. "OS al manly arts

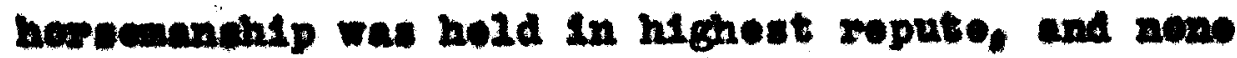

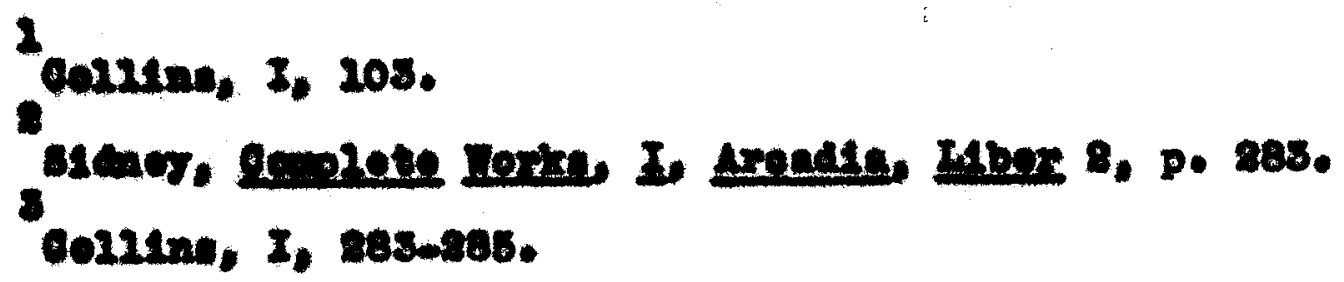


ware $\mathrm{I}$ prowe.

A howenan to is horee, a

noree to zeve o. ..." 2

and In the fortg-firet scumot ho wares

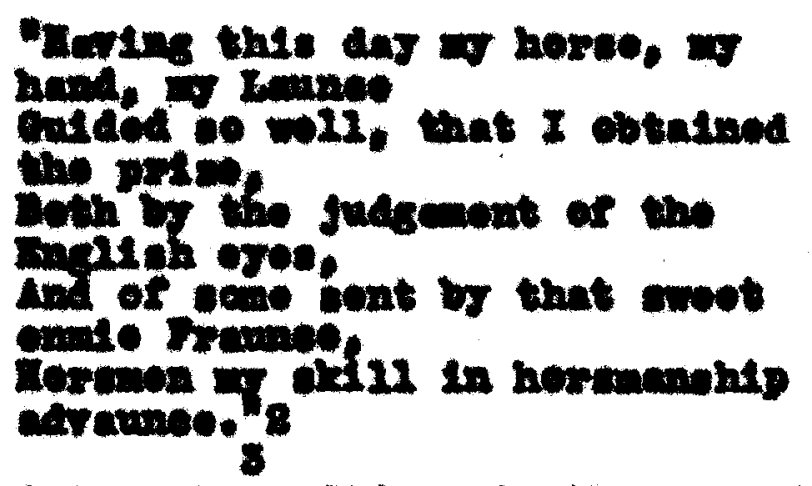

If Peare polnte cat, alow in the seecen boek

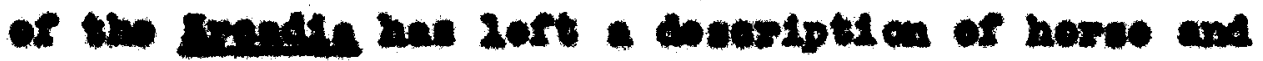

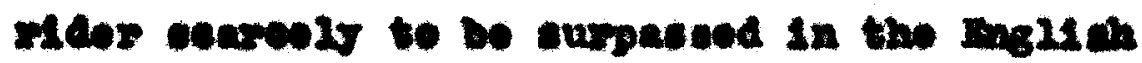

1manage. Io does socm to meloretand the art of

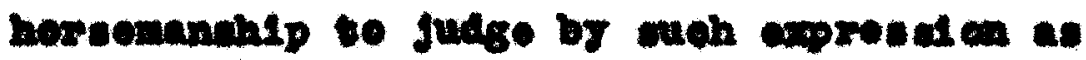

The crog golng oo just with the

nowes, at thox foorta retht, or

trovilug, that it woomed as he

benrened the noween bedy, 10

he lent the horas his atido."

2

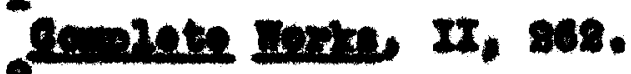

1.20. 21. 868.

Reare, ratrod., arist.

4

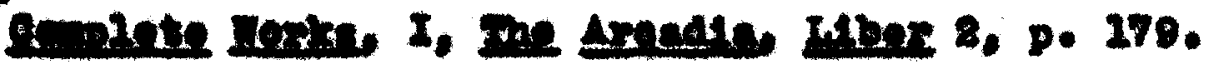




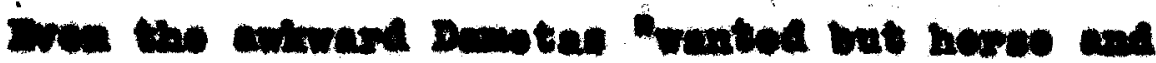

apparell to be as brave a empter at the bost. ${ }^{2}$

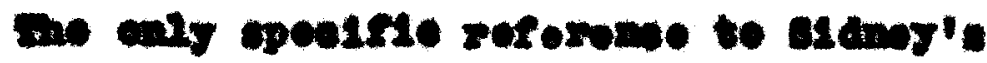

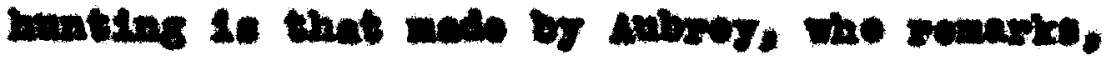

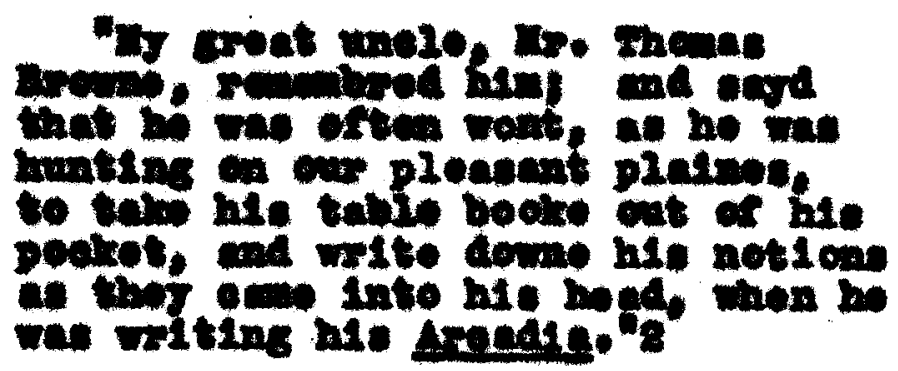

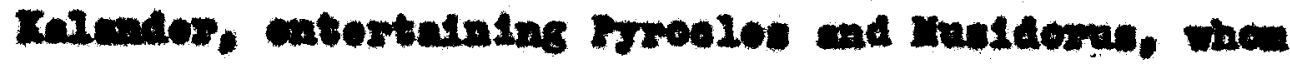

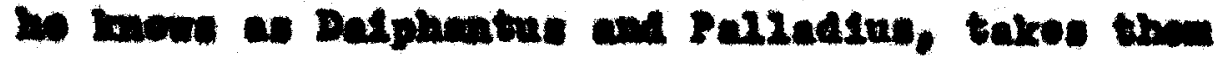

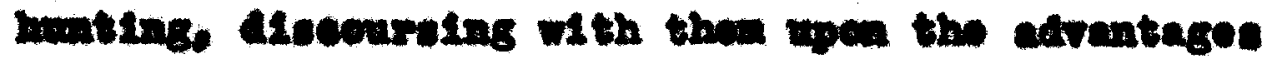
of the mort.

O. sasd ho jou w21. nevor 21 re

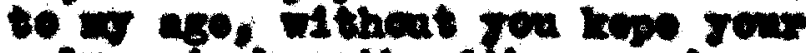
- aroe in bousth with ommete.

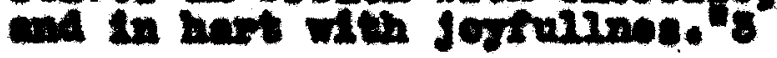

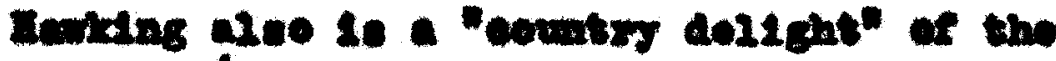
Andis.

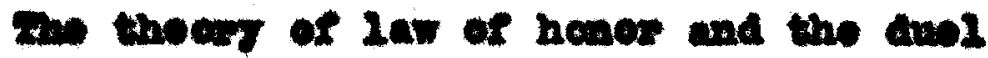

$\mathbf{2}$

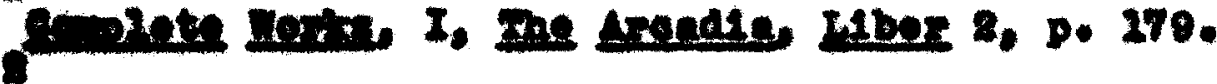
Niver. p. 248 .

8

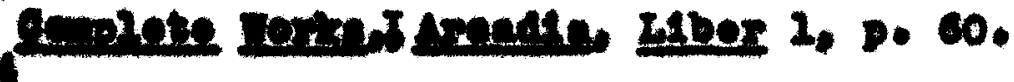
me. rmes, po em. 


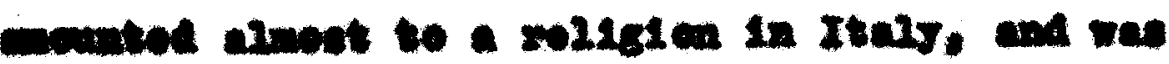

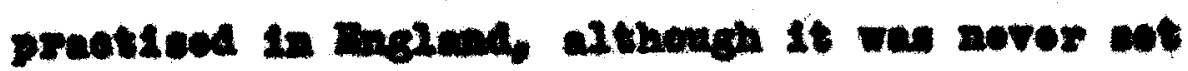

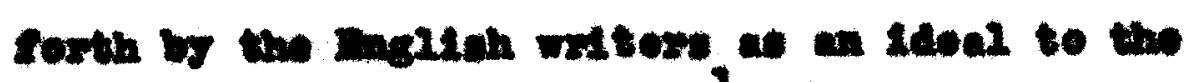

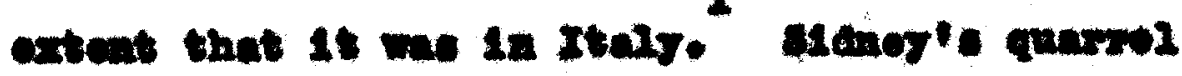

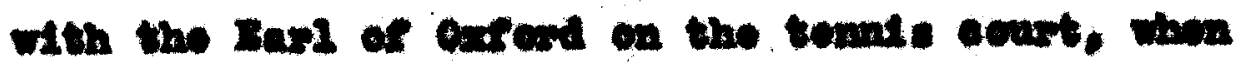

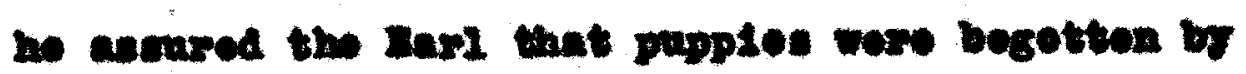

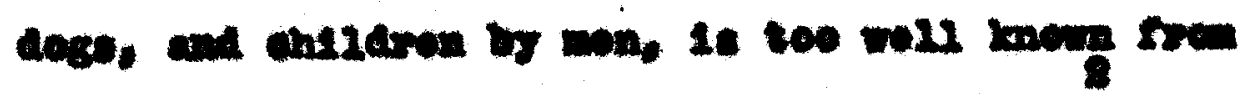

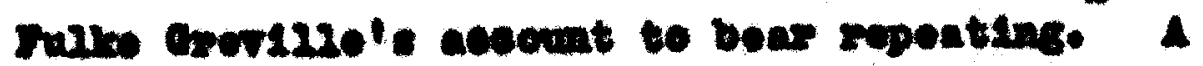

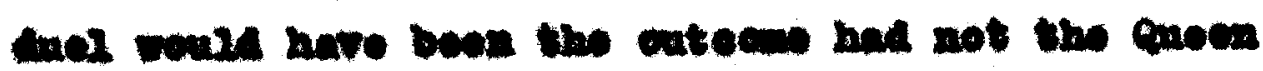

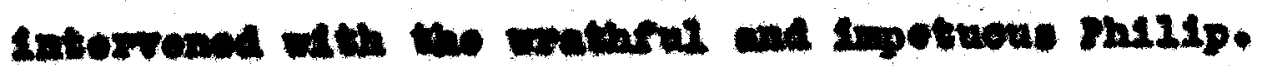
sex110 enges

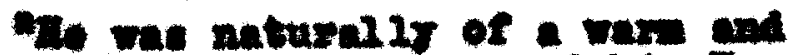

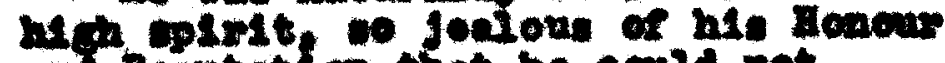

$$
\begin{aligned}
& \text { and roputats on that no ovald not }
\end{aligned}
$$

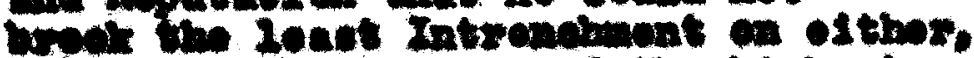

$$
\begin{aligned}
& \text { not wen frem tomene of the highot }
\end{aligned}
$$

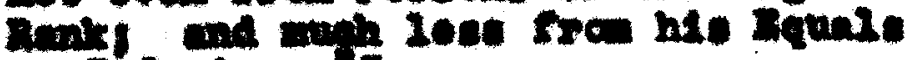

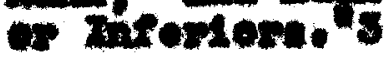

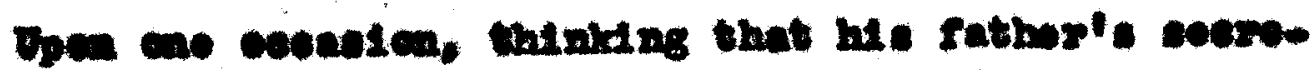

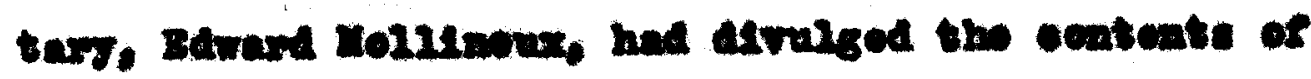

$$
\begin{aligned}
& 1 \\
& \text { INec, Dp. 104,105. } \\
& 8 \\
& \text { crwalle, pp. 68-30. } \\
& 3
\end{aligned}
$$

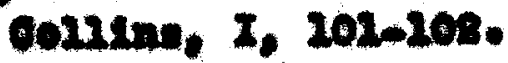




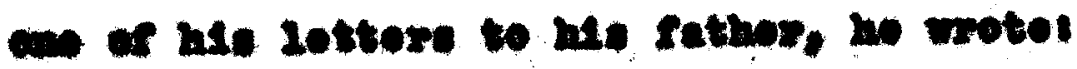

I anpos rew bolore col that

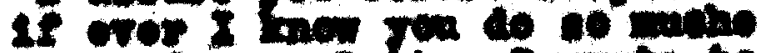

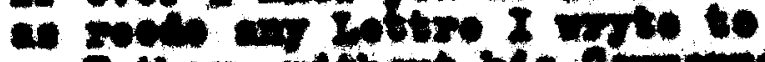

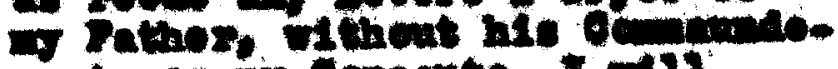

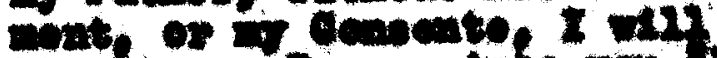

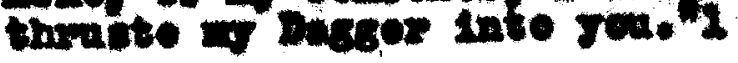

Inagat at not wolly epprowe of the cued as a

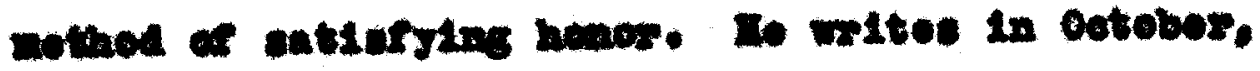
1mo, swa Antworgs

Tren Jour lettor as nell as fren he borth (olnetro) I was inforied of the appute botreen

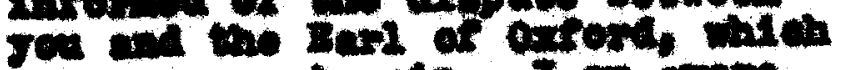

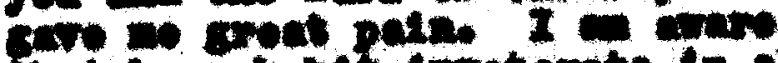
Dace by hable trueberate in an

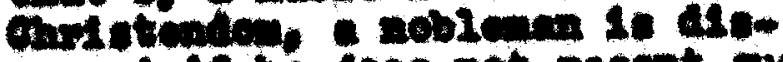

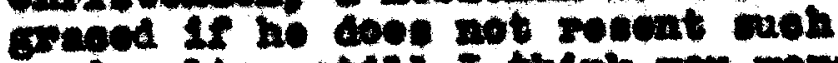

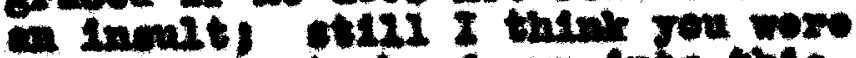
unportunte to be draw into mis

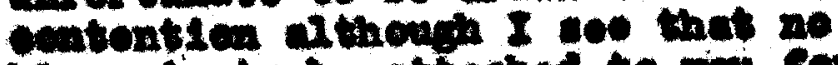
blem is to bo attached to jou $\mathrm{fom}$ 16. Ion en dopive ne tras neacas

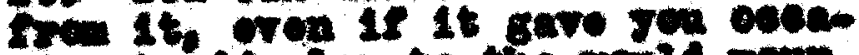

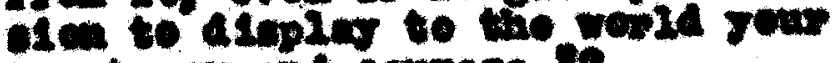
conotand an coureso."

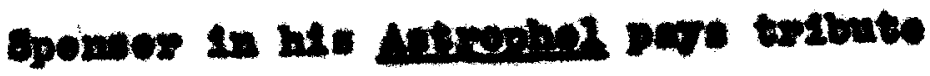

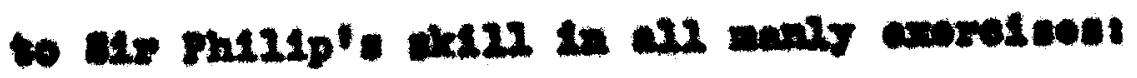

2

exuing, $x, 860$.

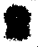

Poure, Dp. 1e4-168. 


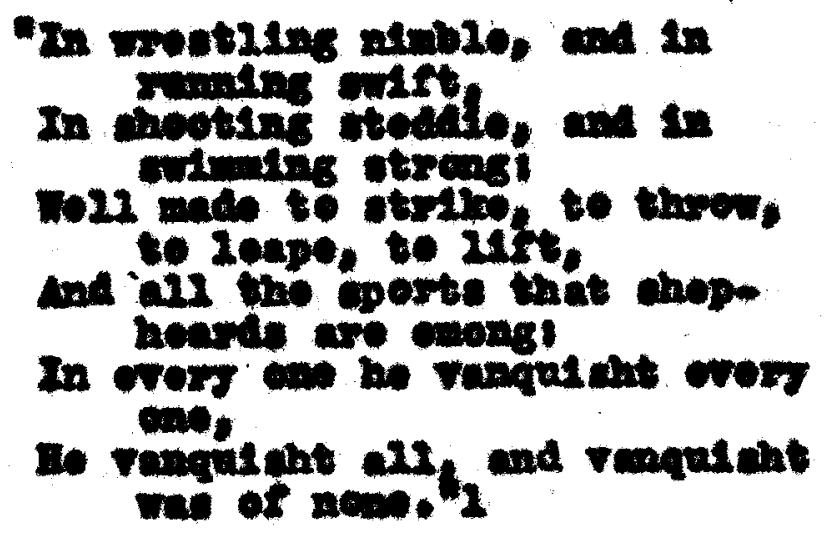

Inwor, his portiolpation in thos

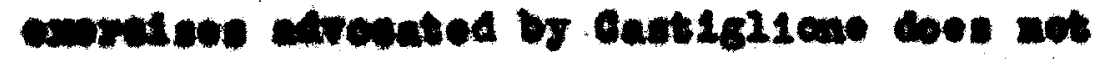

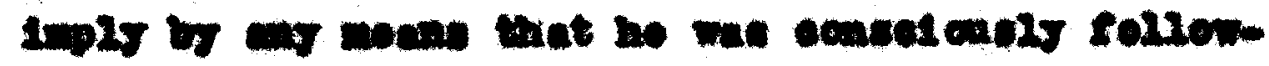

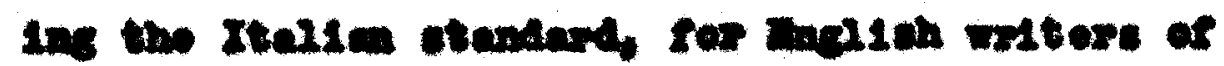
conrters books soliewed the zterien mods in that

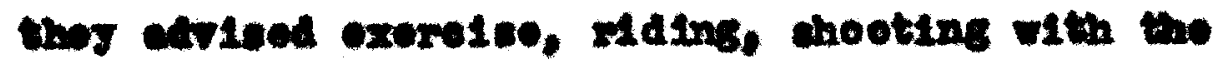

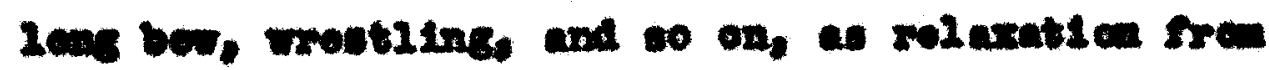

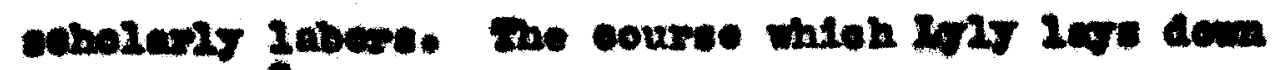

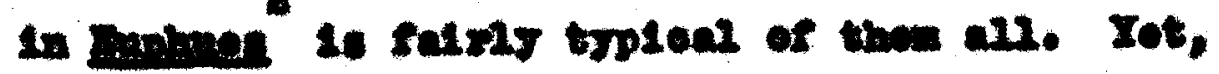

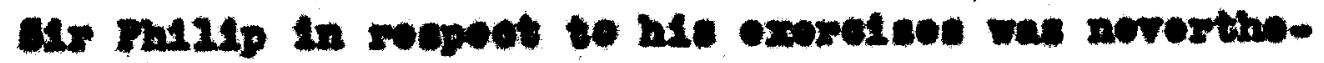

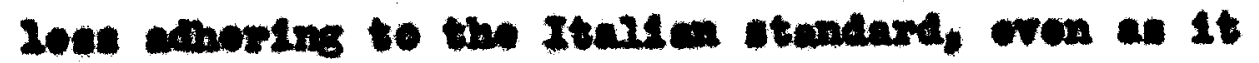

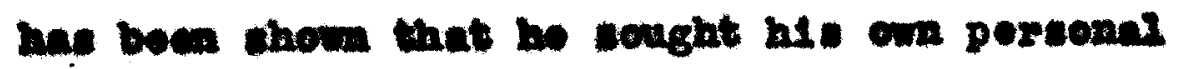

$\mathbf{1}$

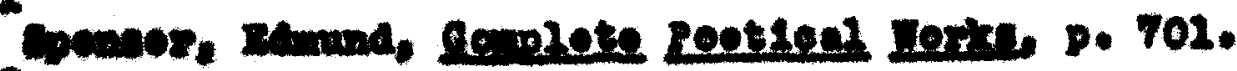
8 47. Iom, Inomens, p. 281. 


\section{$-\infty$}

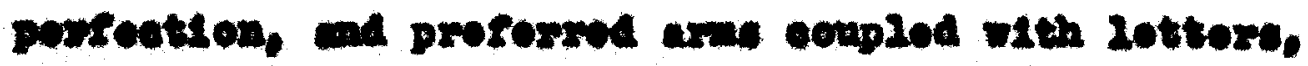
setwor then a propenderemes of 21terary 1150 to the oxeluulon of alletary glozs.

Daf wo in other waje chor himeolf to be tho 14ona courtior sethos then the now gontloment in

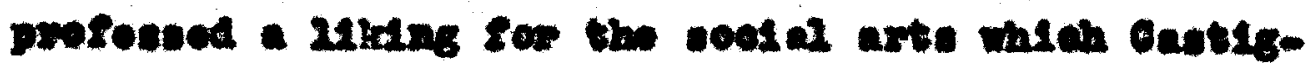

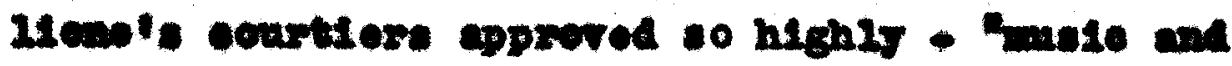

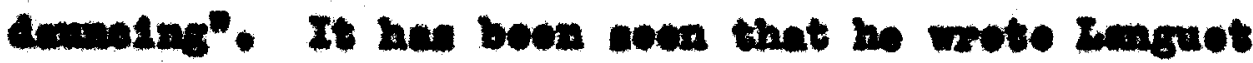
fre Vondes that he wa stredying the sphose and a 21tt20 mank" and that ho wroto his brothes "to toope

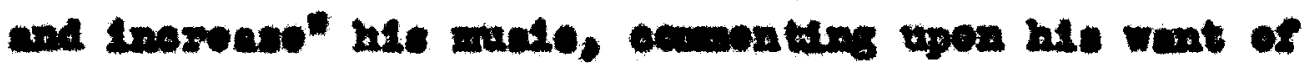
1t In his melenoholy tims. Though not a melol an

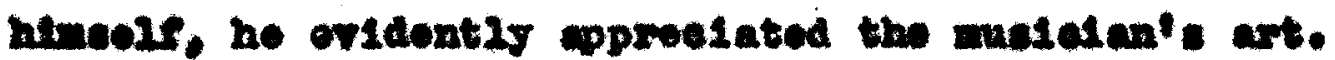

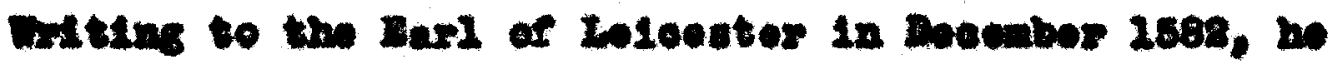
encos.

\footnotetext{
I nal belde of late to note your corithly in the oave of the peer

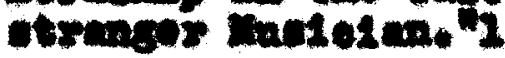

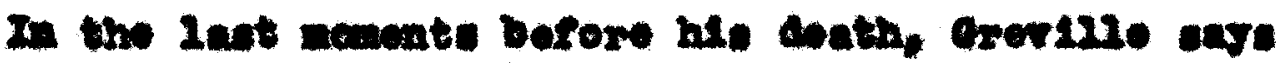

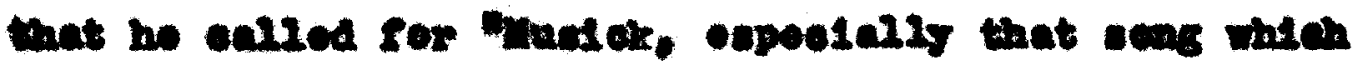

2

covine. I. 


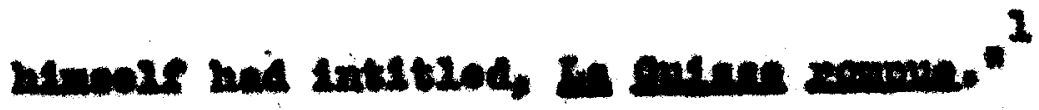

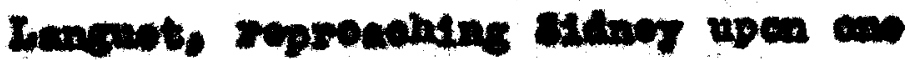

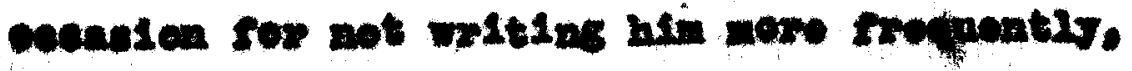

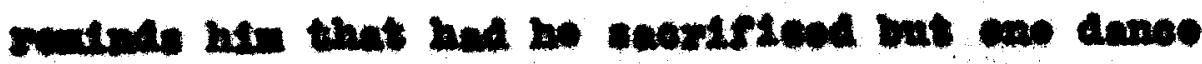

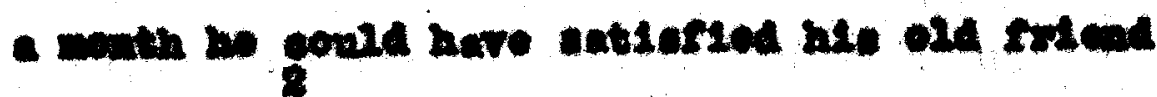

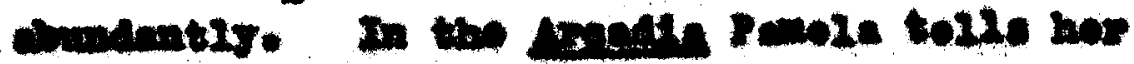

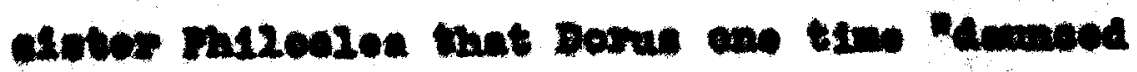

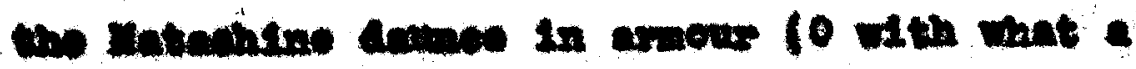

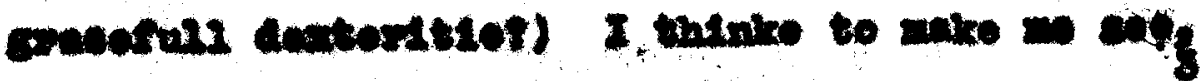

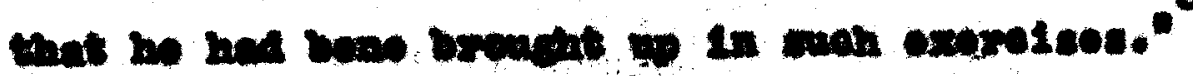

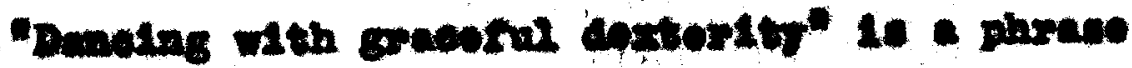

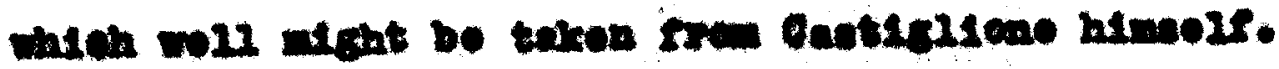

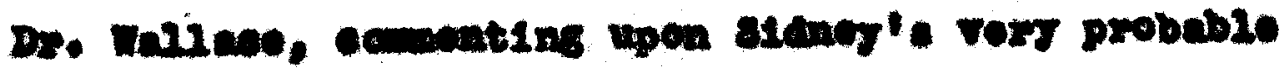

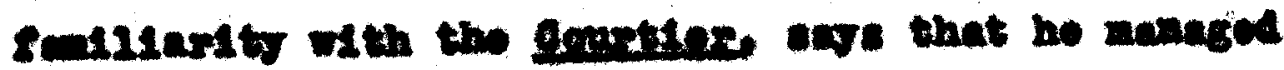

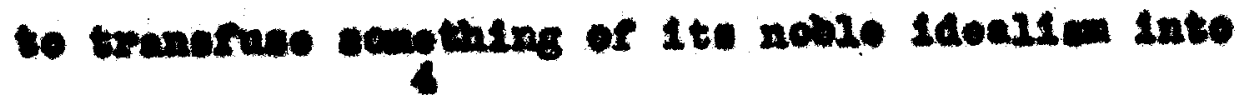

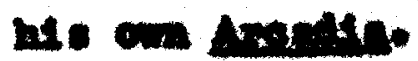

Do Aringe in its ocolnation of

2 Crovi110, p. 238.

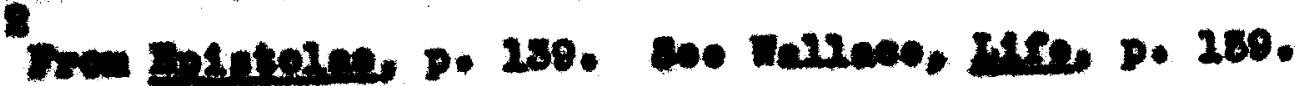
8

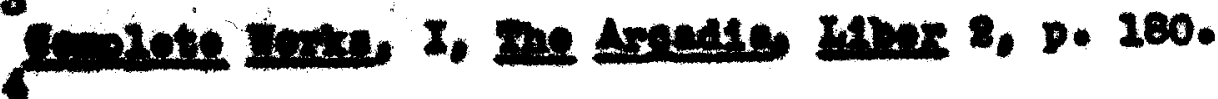
innese, Mt, pe 845. 


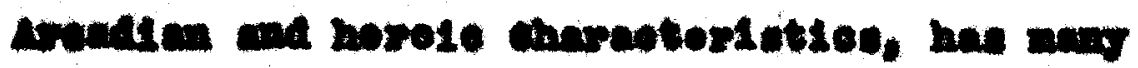

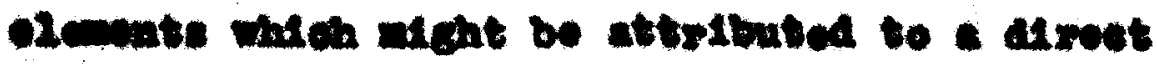

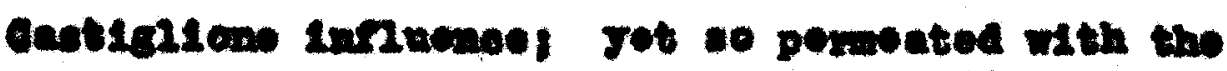

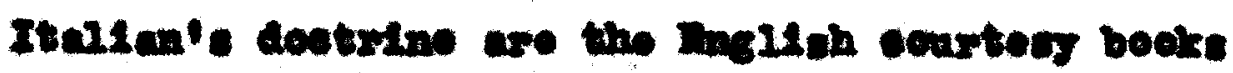

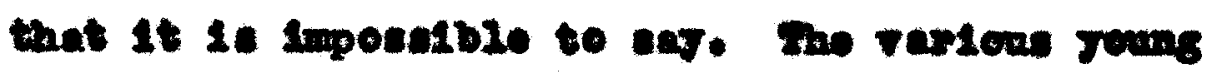
wrose of the seagles cosquor glante, somotimos

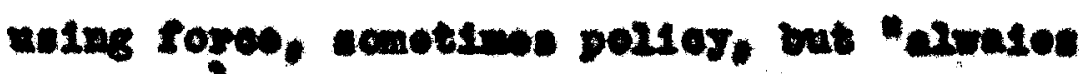

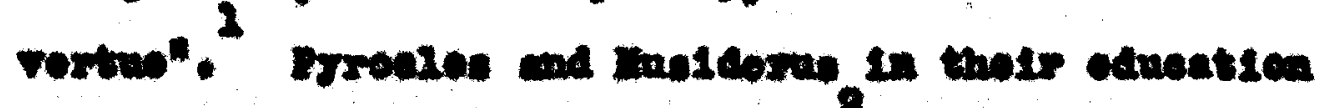

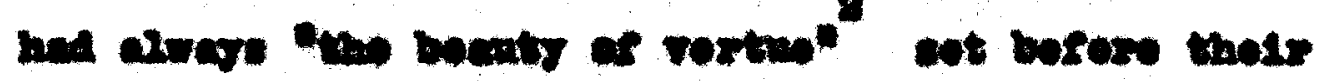

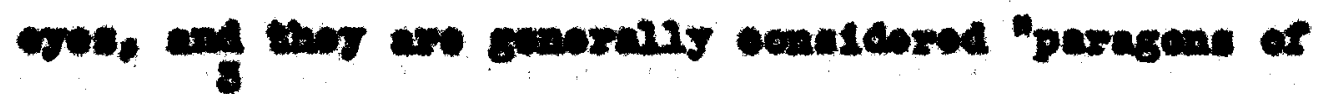
vortwo," It w112 be rowabered that oren noblisty

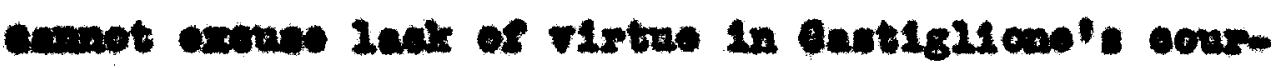
4low. Aleo, hle ocurtios in battle porformod alwaye "In the sight of noble men that be of mont ontimation In the enso" and was not to be last in entering the

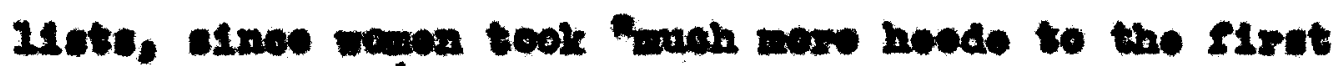

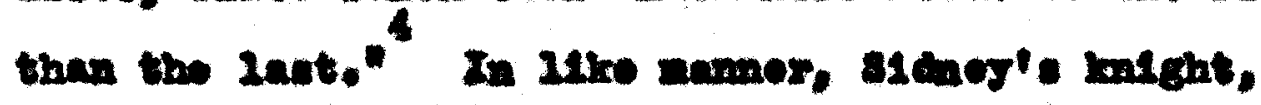

1

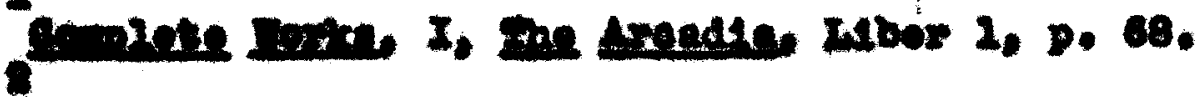

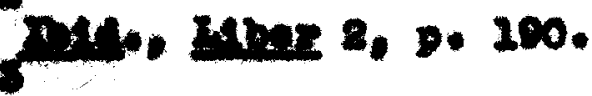

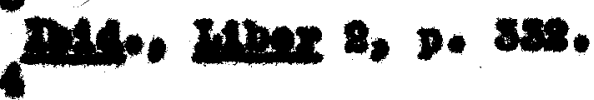
Conterestem, p. 98. 
$$
-\infty
$$

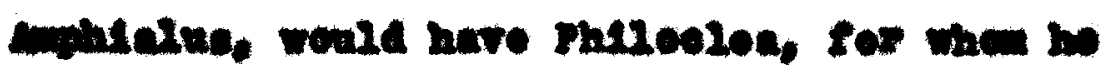

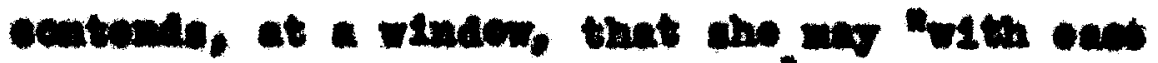

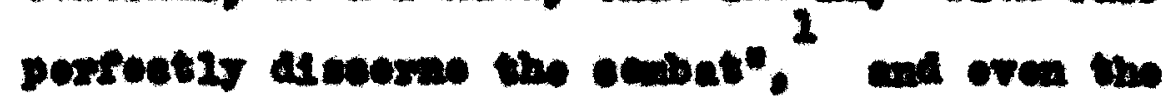

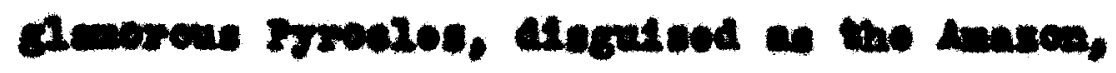

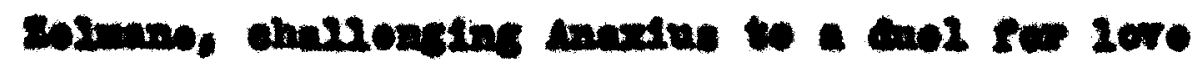
of mileo20a, saje,

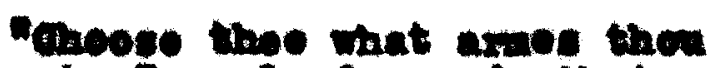
11reat, I canis demateme, that thoes ledes (trom I dofond) may in Inosts coe tho combat." 8

The Detomes ef reen contributes its.

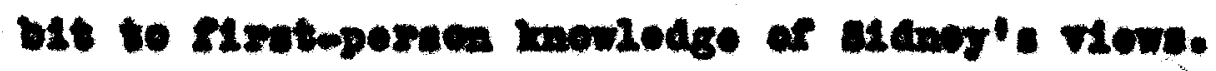
In wore statos that "bho onding ond of ell carthy

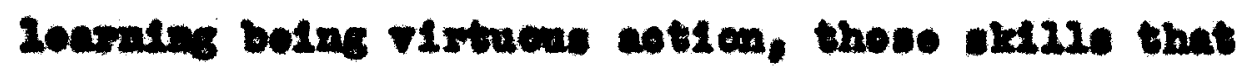
nout eorre to bring forth that have a went junt

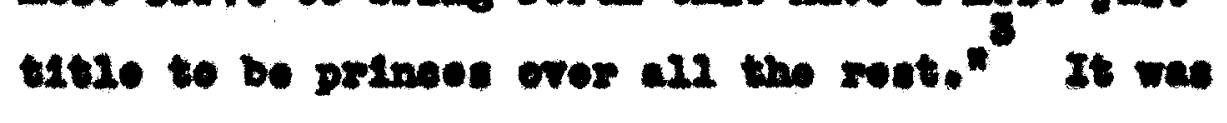
the reoleng, that the ond of earthly 2ourning is

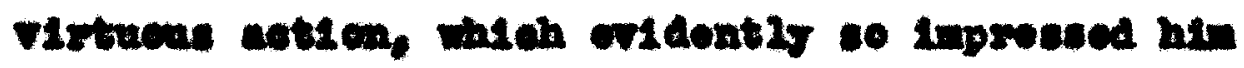
with he owa Inoffoetual 11fe at sourt.

2

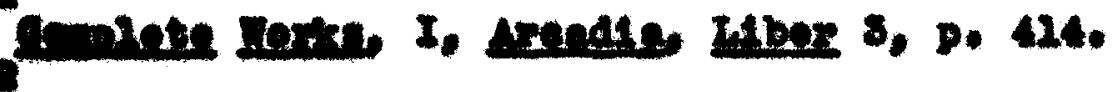
DM. D. 608 .

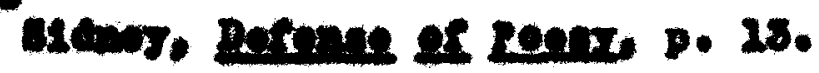


Eponserl framing of his etyle in the Phopheresten Gelender to an old metio language 1 Blding does not allow, olting moooritus, Virgl ard Bannansare se not arfocting 1t. Cantigl1ono also doolded againgt the nue of the Iucean dialeot, an arohaic form. Whothor thore bo a oonnoction with the Italian's argument in Bidnor's train of thought 1t 1s asfrioult to on. 81. Philip'a e1atex, the Countese of Powbroke, of all Englioh ladies, unlese we oxoept lady Jano Groy or quen Blisabeth horeelf, was porhape elosest axin to the Renalseanse intellectral woman of whioh the Italy of Oastiglione'. day had so mang examplose. Hor brother's regard for hor, and hor in. fluonee on him, place hor Indeed anong that raverled 6xoup of wanen of whom the Lady Blizabeth Consaga, and Boatrice and Iabella d'Bote wore outetanding expononta.

1 stanes. Defence af zoes, p. 47. 8 rav10r, p. 274 . 


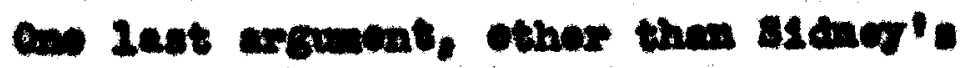

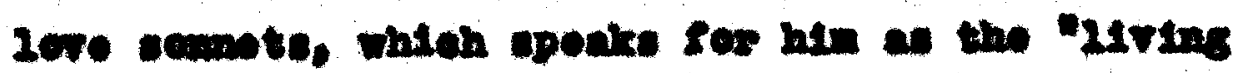

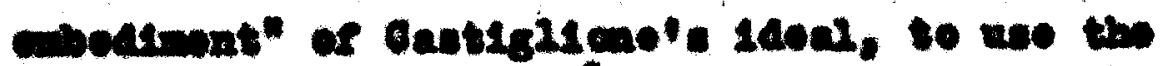

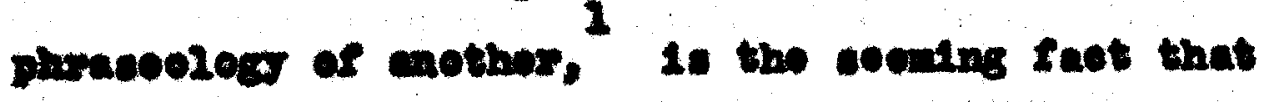

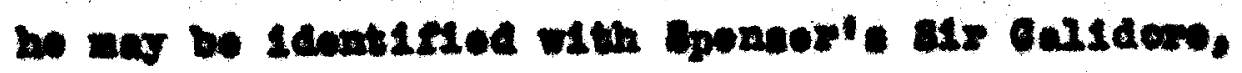
lated of courtion in the eixth book of the Inve

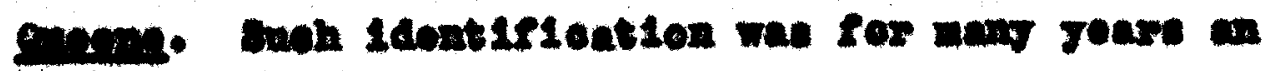
artele of fath of sponeor eoholorahtp, unts of Late jeare seme schelare have attempted to rofute

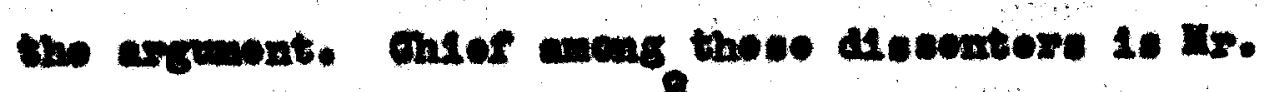

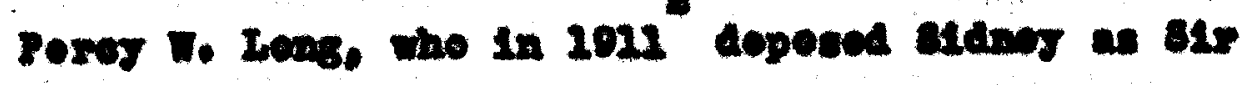

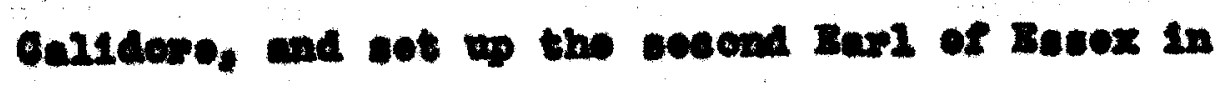

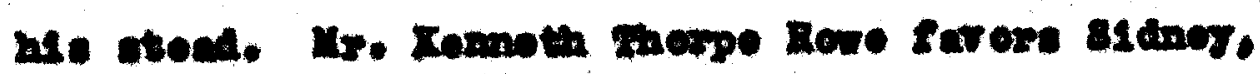

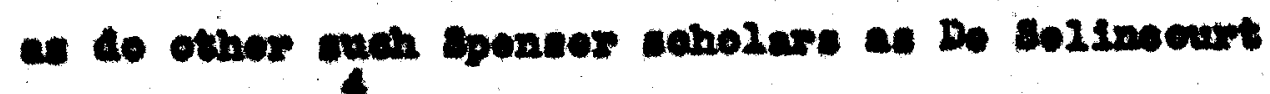

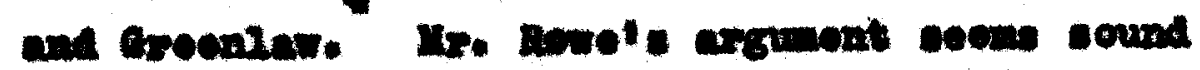

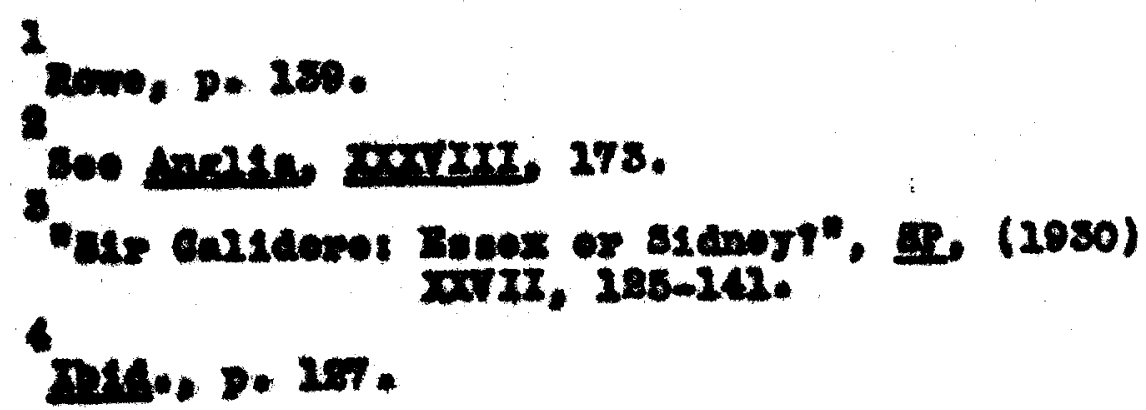




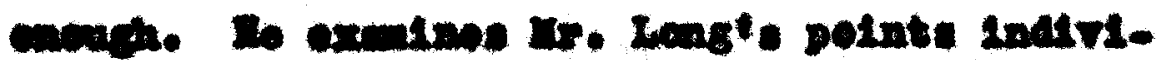

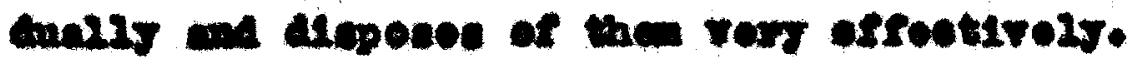

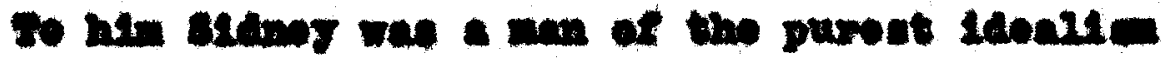
and arallty of the couro 248 be his age,

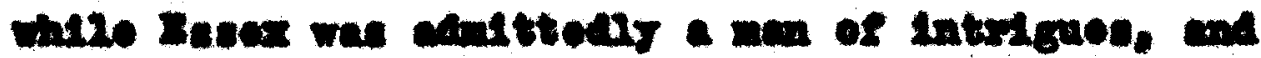

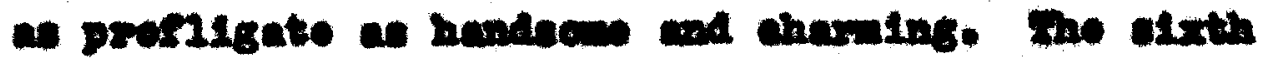

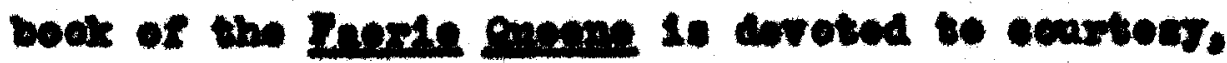

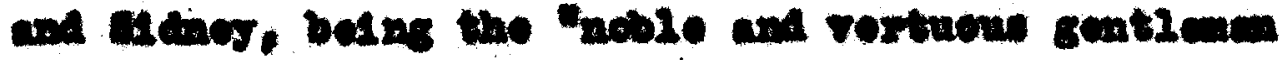
wot wertw of ald bltzen both of loarnting and

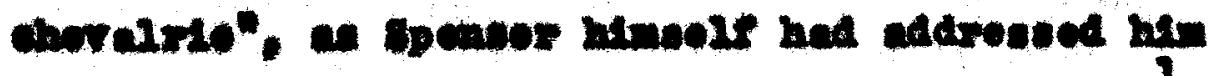

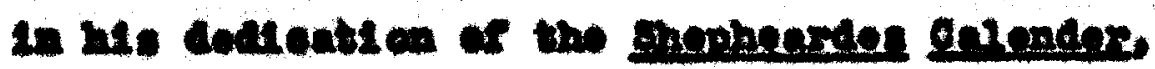

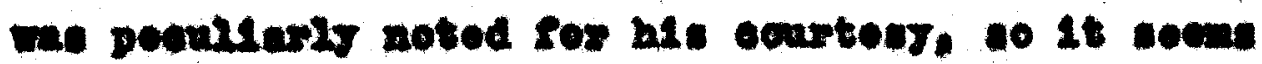
neot probable that ho wos be Identifiod ath als curcero.

In wat wore ate sienoy definitoly portres the now type of Inglith gentionin, whe wade sorviee to his ocunter uppozmout, rathor than the ohtralrome Itakim eourtior wo looked to his om poxtection in

$\mathbf{2}$

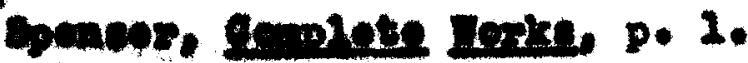




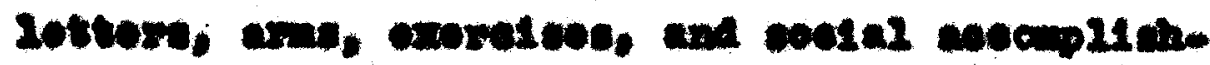
momite?

In the rimat place, ho was intorestod in

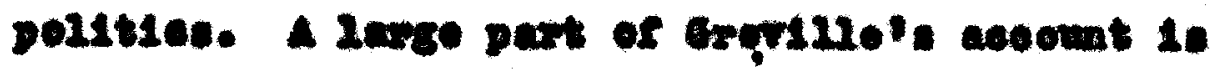

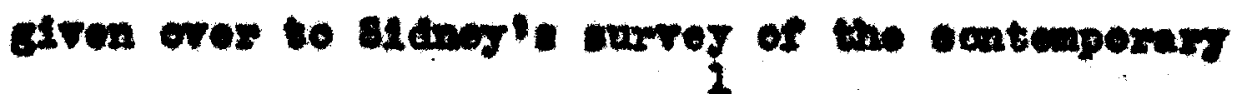
wtates of buropeca pollties. Ito engaged in a

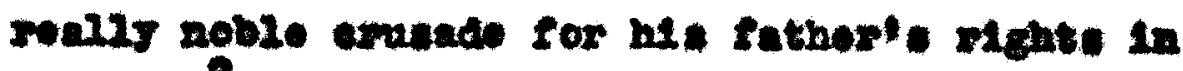

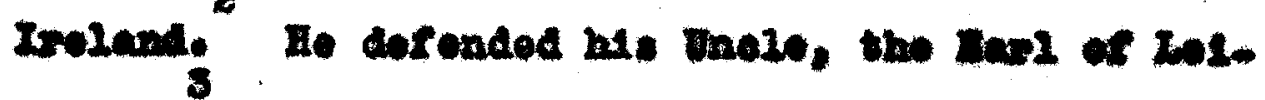

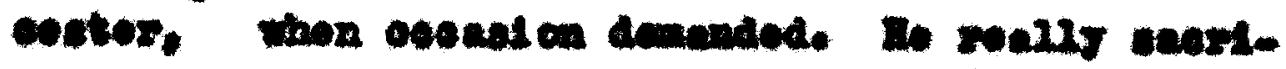

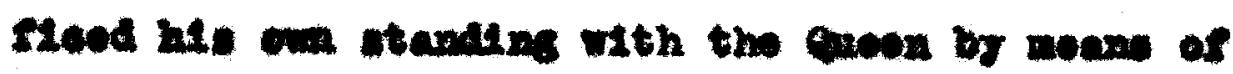

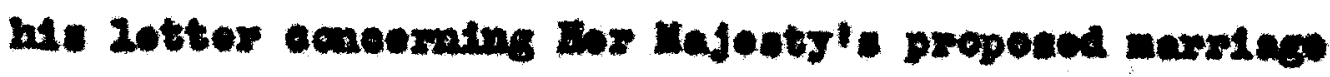
to Alompon. 131 those fats ounnot be galnuald. though longing for gloxy on forelgn land or wes, ho

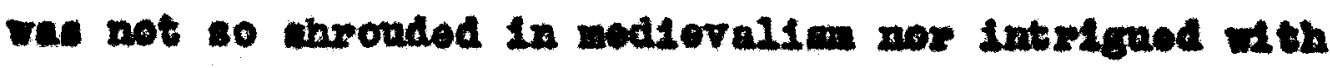
the prompect of romantic seats at aras that ho coule

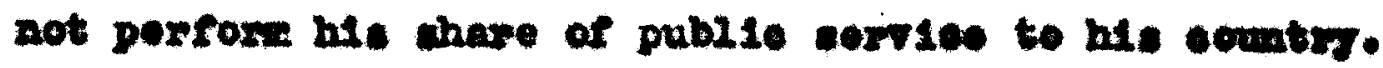
mough a courtiox in nome, he wee orton

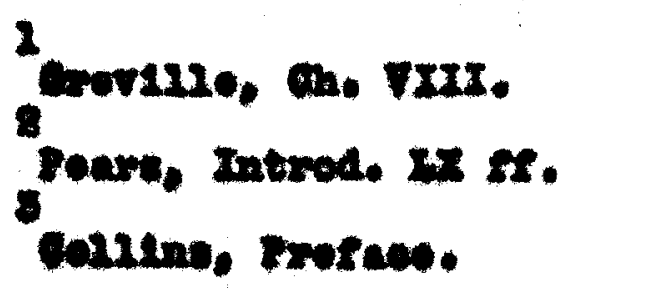




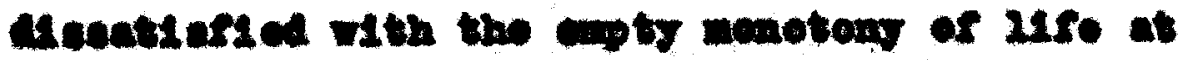
eourt. Ae early as 2078 banguet wroten

II a coposialy comy to now rou eas thet jen at

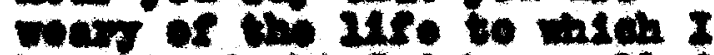

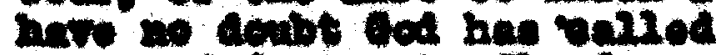

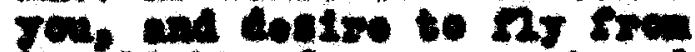
ine ingut of pear cours an botale roweste to poeluce picane to ogerpe the trapont

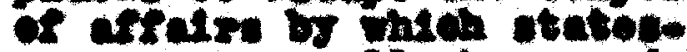

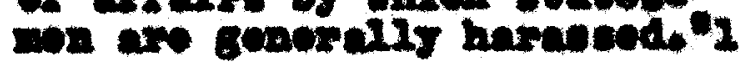

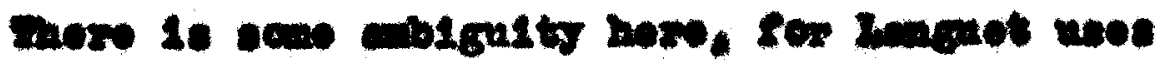

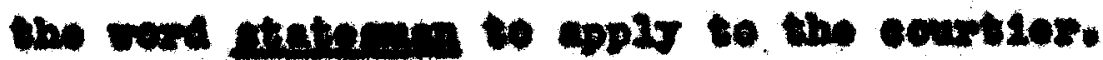

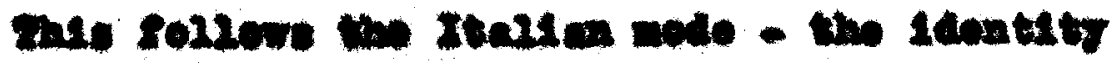
of the courtes wth the advines to his prines.

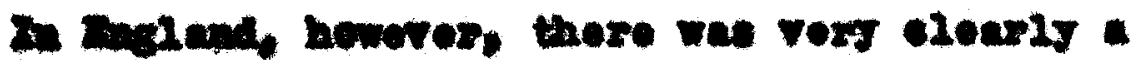
Afrosontiatt on botwoen the torme seartior and itetemen. Iore attanduns at eourt, ath its

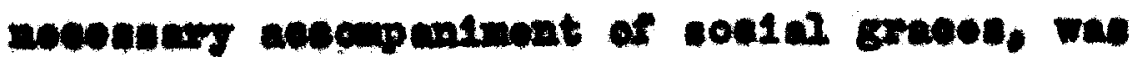

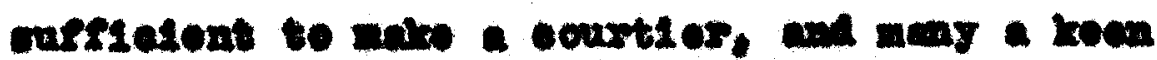

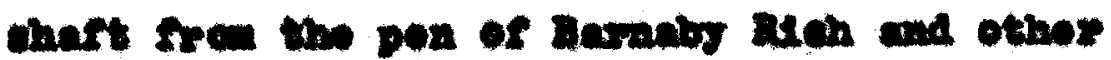

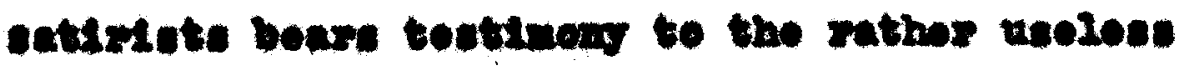

2 Poare, P. 288. 


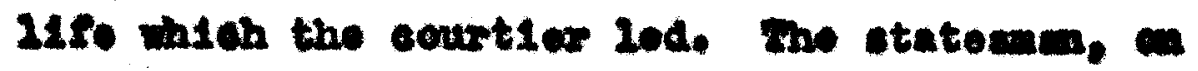
the otbor hond, was the actual adviser to tho cuesn, and woh wen as Burghloy and laletingh were provubly

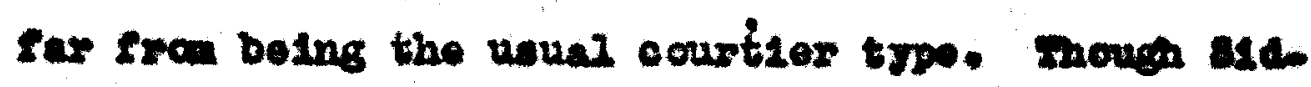
noy did have hie politioal intereate, ho mat have hed as I1ttie opportunity fos putting his theorles Into practice as ho had for putting his calonistes

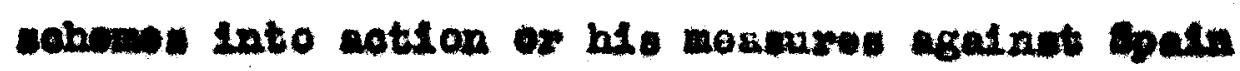
Into play. Whil moari that ho ald utand in the coumbiter olve rather then the stateman alase (tho lattor clace botug ralris typleal of the now ldod for the Inglian gontionen): jot, ecoording to the

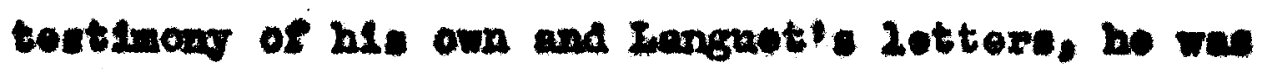
weang of the 14 fe of the court and would faln hare

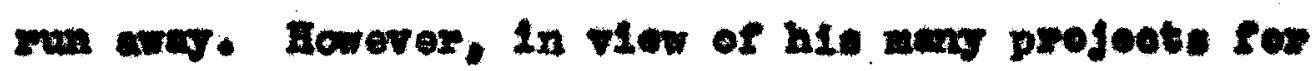
action, and his stmel and lisantrous partielpation In the Iothoriands atruesio, It woald appear that, in eptte of his political intereate, ho ald not

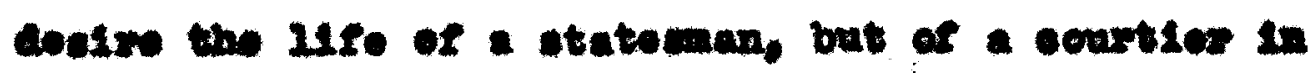
otlew, Alopleying his promene at arme oren an 
Gatigliens's courtles would heve dons. Io was

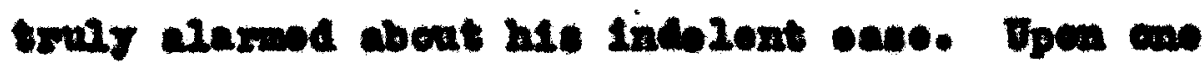
cesation ho waten tonguots:

$$
\begin{aligned}
& \text { gon une of the pori, as rou was } \\
& \text { pereolve, hat plathly falien fwa }
\end{aligned}
$$

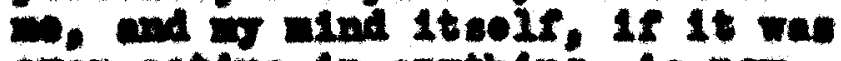

$$
\begin{aligned}
& \text { pror aptive in anthing, 10 nor. } \\
& \text { boginnins. of reacen of y inclorent }
\end{aligned}
$$

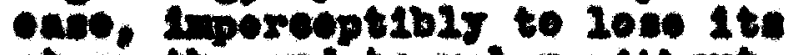

$$
\begin{aligned}
& \text { otsongth, and to rol ax without } \\
& \text { and roluot ance." } 1
\end{aligned}
$$

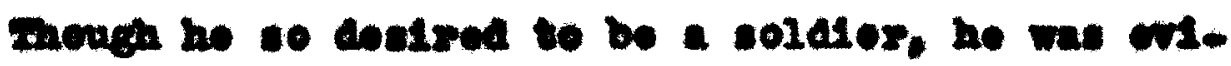
dontig not out out in tho noot doutrable niltary mold. Langat tolle hin in Inaro, 2680,

$$
\begin{aligned}
& \text { "xo opoak plataly. I foer that } \\
& \text { ar the gunisflention of a cen- } \\
& \text { nender enterity w121 be the wo } \\
& \text { In when rou wul be defielont. } \\
& \text { For by nature and inclinatiea } \\
& \text { Jou aro formed tor gontlonese. } \\
& \text { and coldiers cumot be kept } 8 \\
& \text { tholr duts withent uoverity "s }
\end{aligned}
$$

the noet echeluedro point ageinst 8LF

Phisp's conformity wth the Catiglsoas ideal is his rellg10n. Platonie $10 \mathrm{ve}$ for the Itallans tock

2

Poars. p. 245.

8

It:o. $17 \%$ 


$$
-201 \text {. }
$$

the nature of relletion, In his 2180 Ratenden pleged 1te important part, but it wat not he

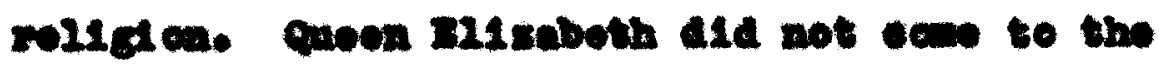
threas wats he ves four reare old, an he $14 \mathrm{red}$

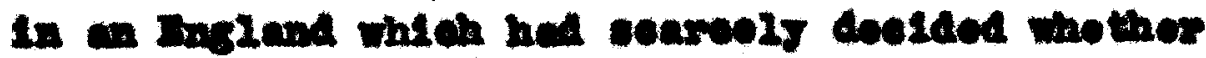
1t wa 2xotestant or Gatholit. Invertholose, the

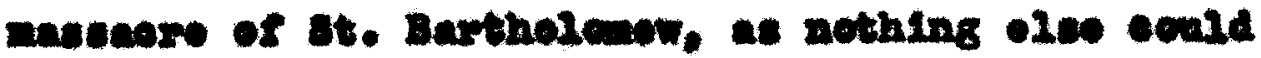
have dow, connidorably dooponod in his the Prom

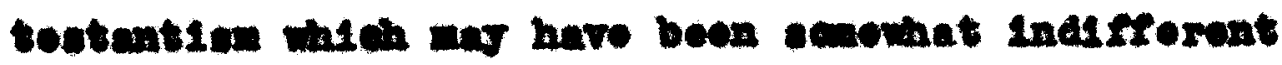
bofons. Ienockerth, bo was a dovout Ixotentant,

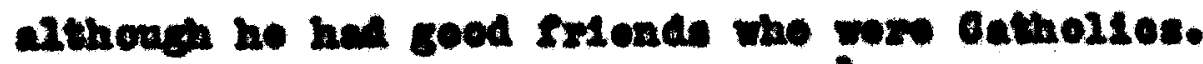

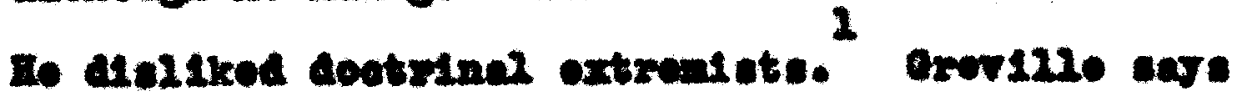

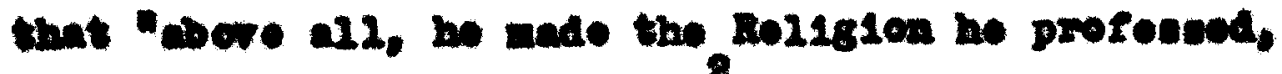

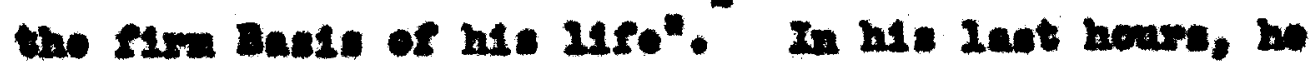

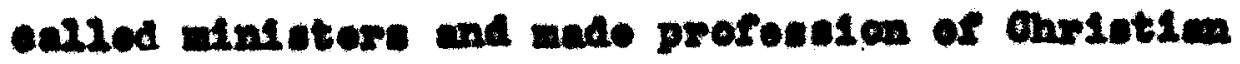
fatth. Lecoralng to Groville. the last noove of

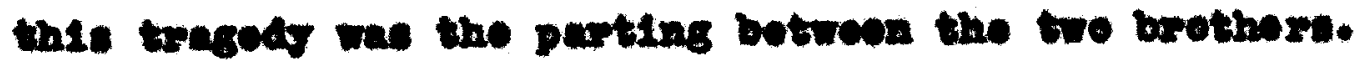
the oldor took he leave with those amententing words!

\footnotetext{
2 8

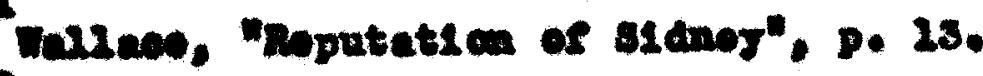
Gorazle, D. 36.
} 
200

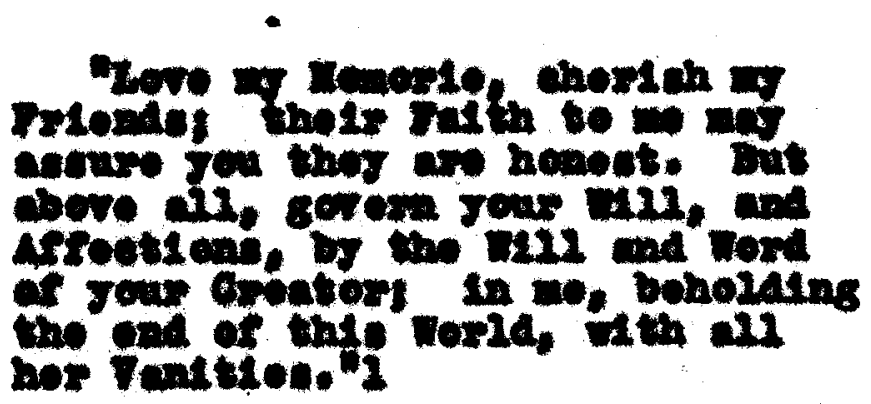

2 arri210, pp. 280-210. 

apena $x$

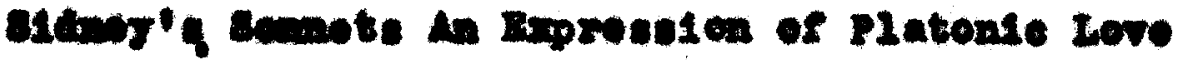

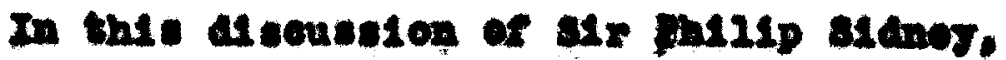

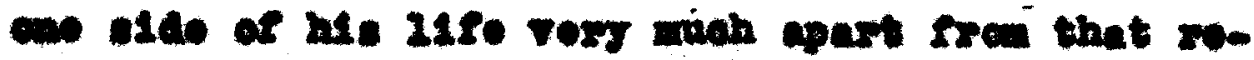
voalod in his comroppondones with lenguet or by he friond Fulre Groville hat not boen touched upon. Iot, It has a vary proninont boarlng, and eamnot bo

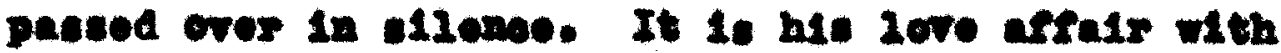

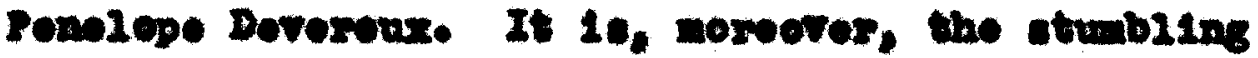
bleak in the was of all wo attempt to anrive at ar corinte conolunion as to the man. Sano oxities thint the "Aotrophol and ste12a" connote are expronllive of r2atente 20we. Hew of courne do not agres. It 122 be remombored in tho oumary of Afforonees at the ond of Ohaptor I botweon tho Itarien

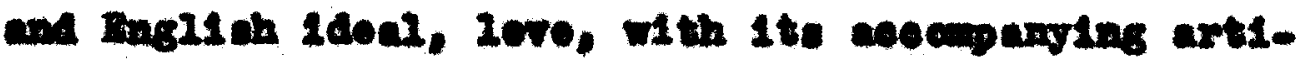
110es, was rathor on Intogral part of the Italien courblex's 21fe, wile for the ofxteonth contury Inglien gontioman it wat not a nocescary roquidelto, 


\section{$-212$}

and is int inciuded an oueh by the witere of

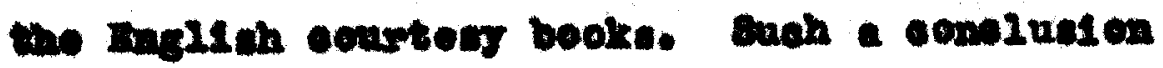
1. opon to exttielun, for the flood of 100 oumote of the Exisabothin portod weard coen to Indeato that 2070 asd plas in iportent part in

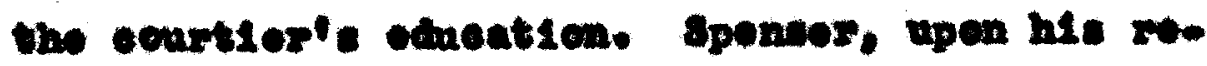

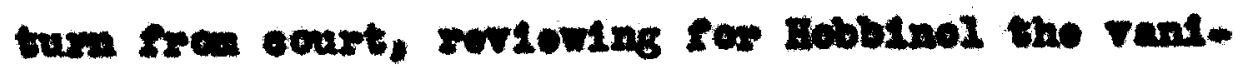
110e thoxe, sers that

\section{Tove not aboundoth thex} For 212 the walle and pindowe hore aro wet

A11 sul2 os love, and 20ve,

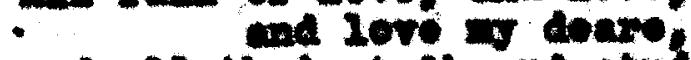
and al thos talk and otude 1. of 1t."

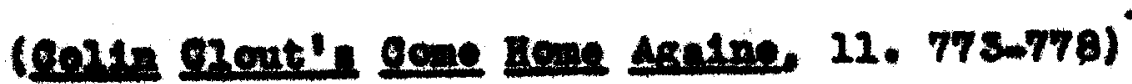

the truth of the natter is that the are Bagileh

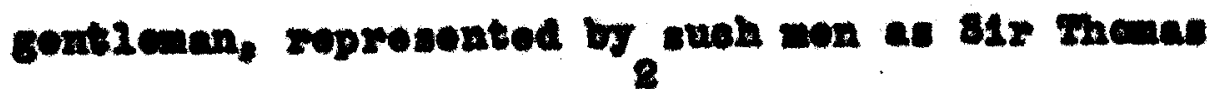

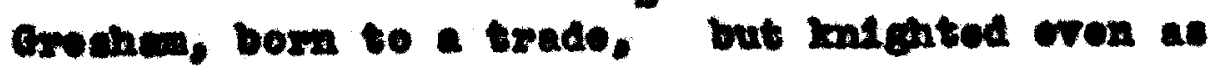

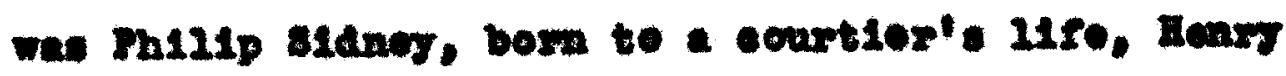
Reachm, who spoke for the "oempleat gontleman", and

\footnotetext{
2 Eponoes, Aconiete Dorkn, p. 696. 8 rolee, p. 10.
} 


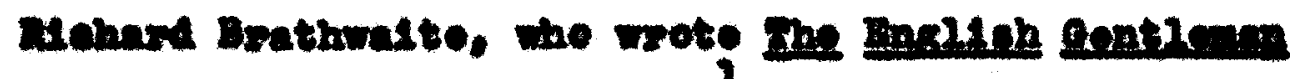

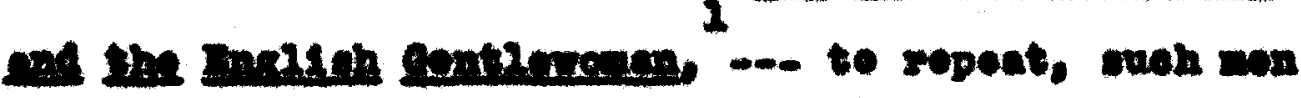
al those would have fremmed upon the inoluet on of

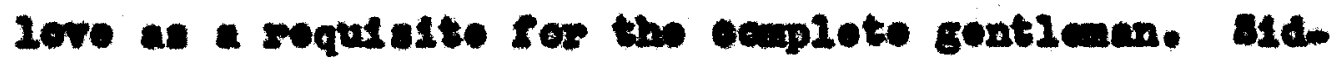
moy, though he hat bowa called by no lose a poreonage than Colexidge "that gontzenan of Durepe, that ellacesapliohod mon". was, coplto his polltion ino teroste and $\mathrm{hl}$ boredon with oourt actritien, woro

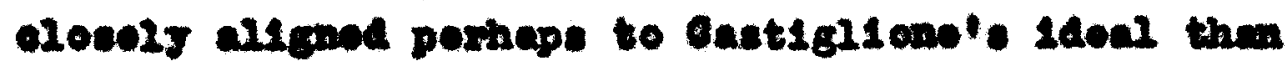

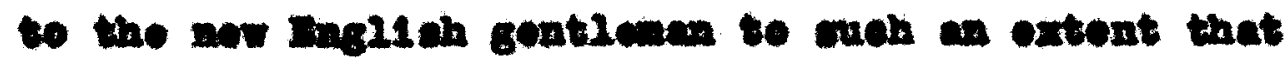

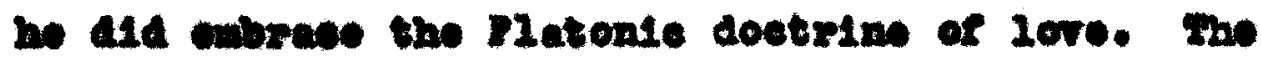

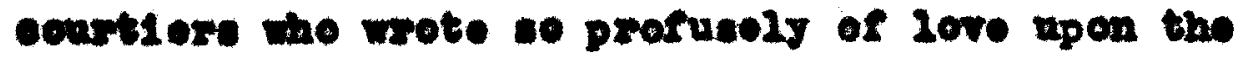

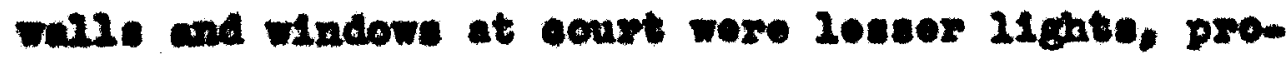
bably inctatore of the Potrarehen sehool, and in no wae to be confused with the now type or Baglich gon-

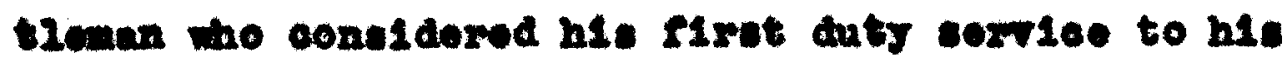
otate.

4r. Pox Bowras thinke that sponeer's Eeteh

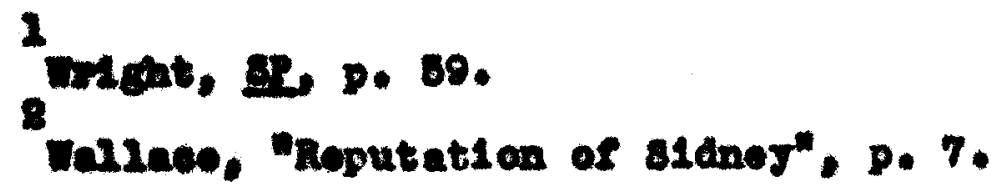

1 nucte. 8. 8. 80. 8 Walnes, "Roputation of sidner", p. 7 . 


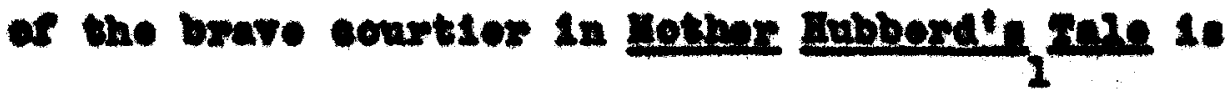
Loasis intondod as a portrult of stener. Ite ouperierity to the pien onew of comon courtione

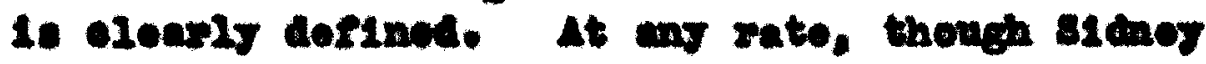
was wons the "ocmen courtiers". Jot not of thon, bo wae at the seme time a witer of lowe nownots. and is thorefore andedate for the additional tout wich ula roloe applios in distingaidhing botwoon the Inclinh geationan and the courtior.

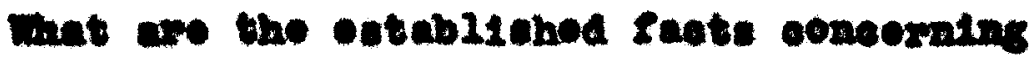

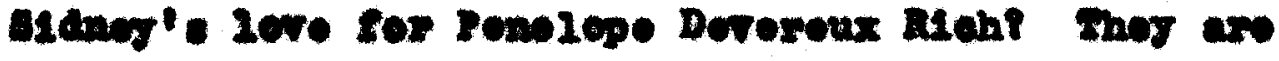

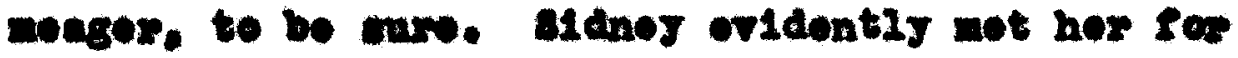
tho riret tine, an has beon proviounds noted, et onartieg in 1078. Whe was then onds twelve or thir.

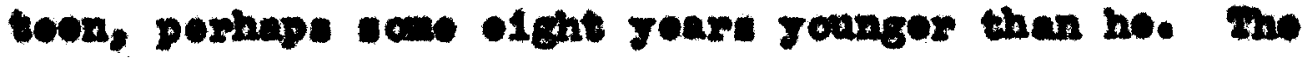
Barl of Basex, hor fathor, had on his deatbibed oxprosed a wioh that stding warry his daughtor. In extent 10ttor Indseates that a formal agrecment was

2

Pen Deurne, pp. 245-846. 8 Eponses, pp. 90-200, 11. 718-777. 8

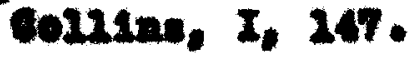


Aram wo and aceopted botween 815 Bons s1dney and Indeotos of the one part, and the Barl of

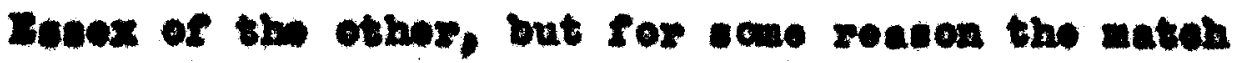
was broken off. In 2881 Ponolope, by an arrange-

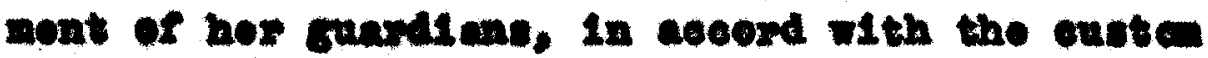
of tho tim, was narried to tord kloh, very wahapply se, it ceoms. At. ans rate, slenor. Ior

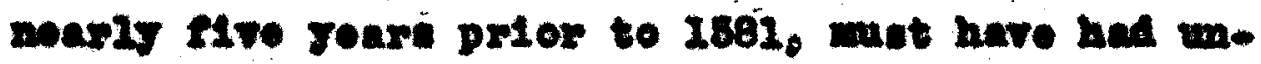
wrual epportunitios of seelng hor ortex, for hor

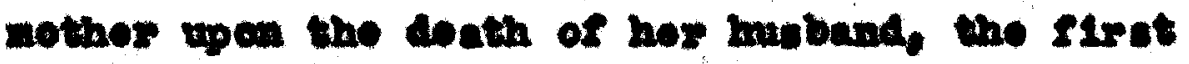

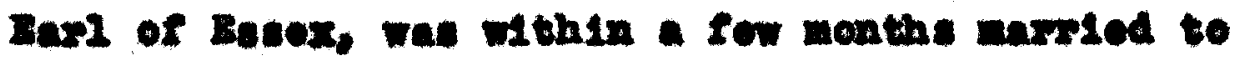
the Barl of Inloottor, and of courne bidney for a gent part of this period unde Leleester House his

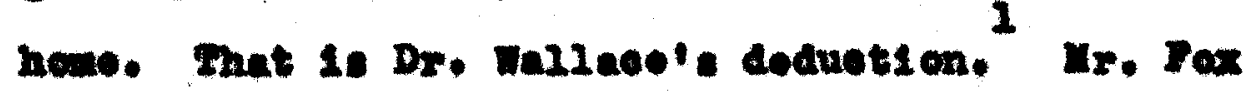
Bourse, of the othor hand, think that ronolope, arter hor mother' anriage to Lelgestor, wan taken axpe of by tho Barl of mantingdon. Bren though this wore trae, howeror, she mat frequentif hare visted hor mothor. Also, the Barl of Iuntingdon'a

2

P. 248.

Pox Bowne, p. 237. 


\section{$-218$}

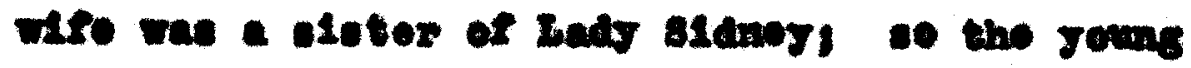
covetior and the attractive glnd woot hore often beon theows togothor.

Just wen sldeg started walting his sonate is a nattor of ligpute, but Intoranal oridence make it alent that ond a mall muber of the could have been witten prior to penolepola marriage in 1801, an the romalndor wox unioubted25 acmposed botwoen 1682 and 1885, she 2atter date boling the jear of aldneg's own marriage to Franeot Valatnchen. Penolope borgelf lived with Lord alch for a mobor of jeare and bore him throe wonk and three cakghtors, but wes ultimately atroxend to bo.

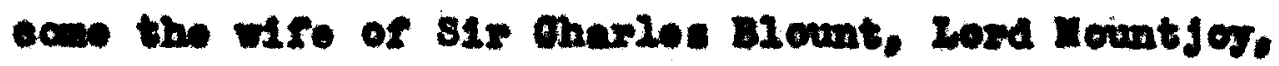
arter beling that nobleman's atotrese for some joure. moee are wellmetablimed facte, and the alngniar thing it that hor sonduet does not sow in an way to have alienated hor friend or have afreeted hor pouttion in sooloty. Mr. Fox Bourmo secme Inelina 


$$
-210
$$

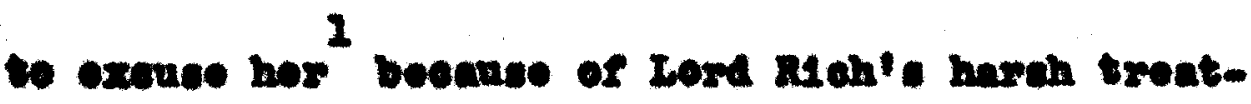

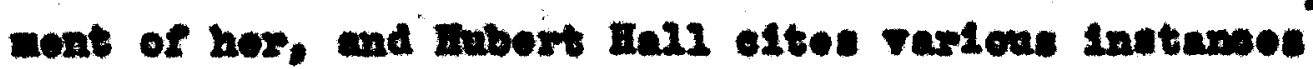
of elmilar condunt, wong the noble familses of the porlod, nowall quontlonable to ni, bat oridontly cocuptabio thon.

Rogardiose of what Ronelopelo om charactor

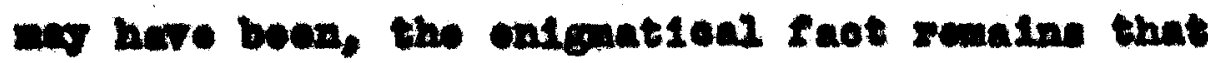
malip sienes, the noblo pattern of his age, aldrovect

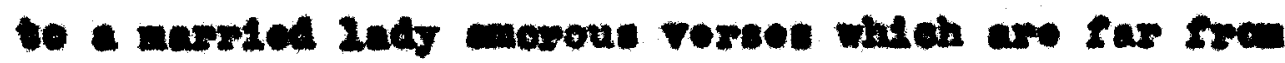
sodate in tos. Whet this paradox soholare hare arged and lleagroed for geare, and the varlone conm

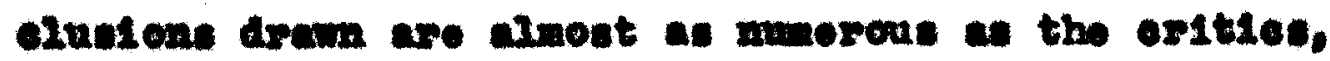
for sew of thon hare agreod at to all the dotalis,

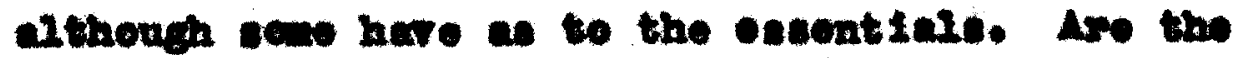

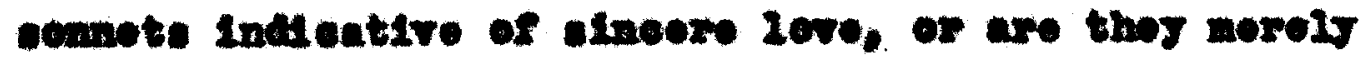

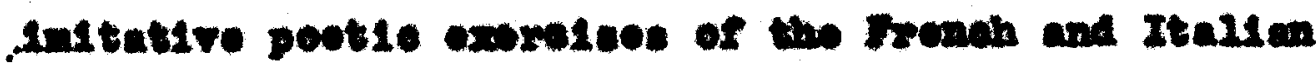

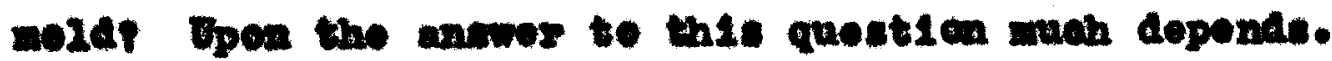
Dr. Wellese considere the connote eseontlally

\footnotetext{
2

Dor Bowrac, Pp. $246-846$. 8 1011, pP. 00.98.
} 
eutoblographicel, therefore incere, in apite of the1r obviously conventional character in many 1 reapeote. He reoognizen the faot that sidney wae an eager atudent of Italian and Preneh 11terature, a dsolple or Petraroh, Ronserd and Da Bellay, and thinks that when he was ready to write somets he went to those who were the reoognised mastere of the form. He bellever that at the time of Ponelope's marrige there is no raseon to think that sichej conoldered himeelf her lover in any but oonventional 11terary enae, and that the rirst thirty-two connets, with the aingle exception of the twentyfourth, wore obviously written before her marriage. Then, with the thirty-third sonnet stella is now the wife of another man, and slaney heaps upon himself reproach for his reoent paseivity. All his ohlvelrous instinota are aroused, and ho decides to play

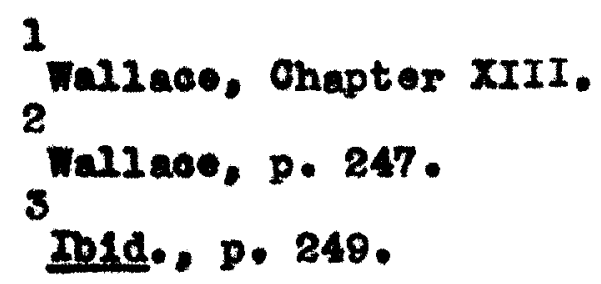


th wele of latghtoorwnt agatnet the viliatnous

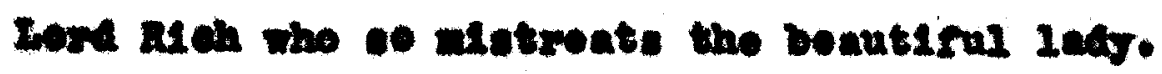

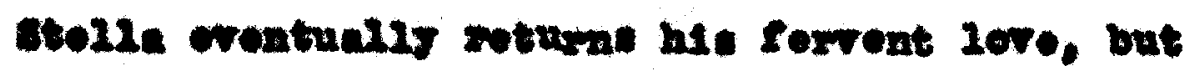

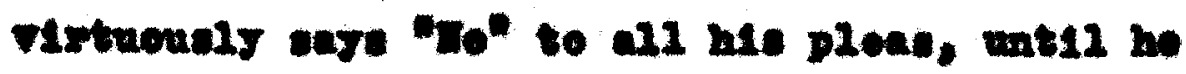

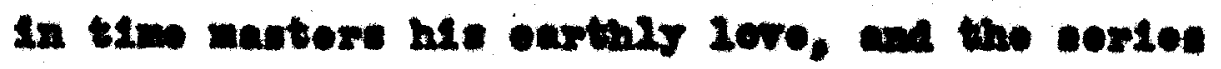
ode in the sull eraxtation of boarealy 10ve. In

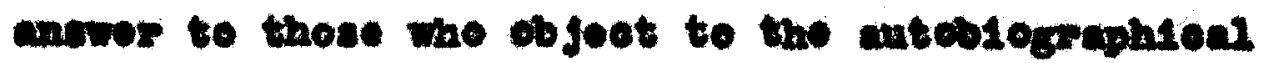

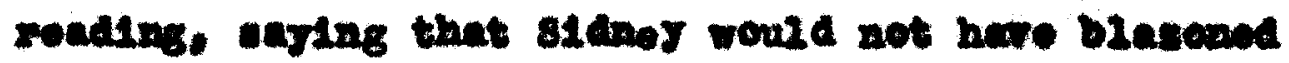

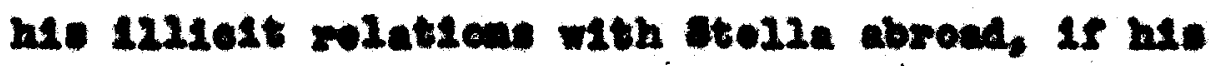

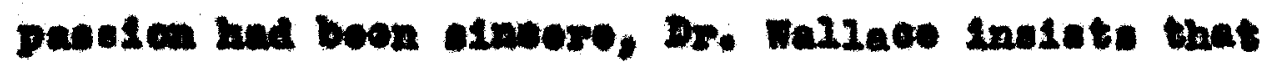
the sonnets were not blasened abroad, that the wowe intlmate wow reaerwo for stolla and perhape the Countese of Pesberes.

4r. Armond conelders the consets atebleswaphasel, and hat oonetruoted frem the soxtes a wale romanoe. with each otop in the growth of ach nog'. pareter elearly marked, altheugh bo doos

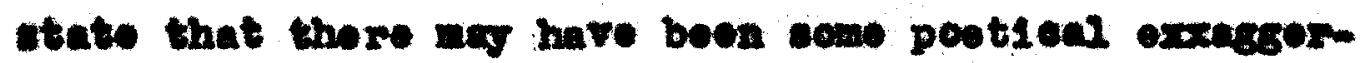
atten - In other words, ho does not bellove "that

2

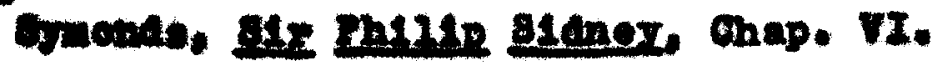


Stdnoy would in eot hove roally gono so sar as

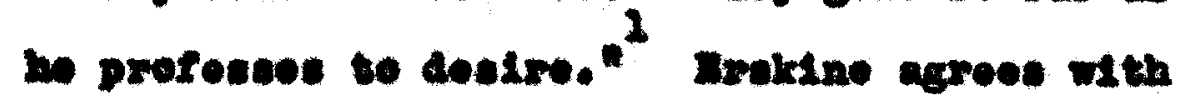
Wlices, and belioves that Indy Rim 20 wod

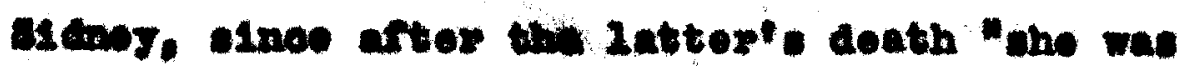

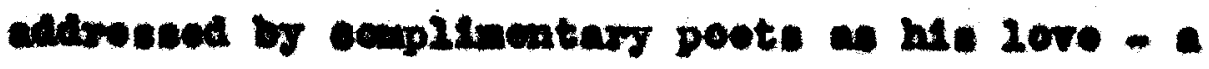
14borty thog gevid haveny have trion had 1t atem pleased hor."

Ix. Delvinates has the ou bolles that cldnes was alnowre in he mowowe protentation, but that thoy wore addrosed to an lesal of ht

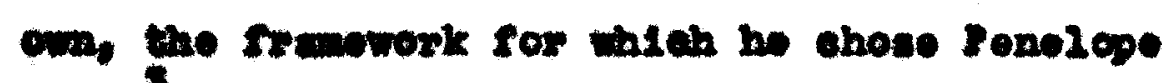

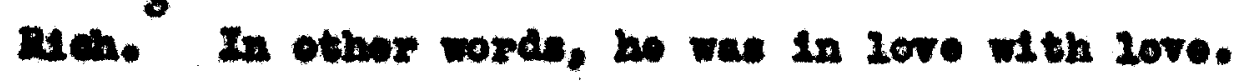
Elenos too considere the pennote frankly Inttative, and devold of an autoblographle algat.

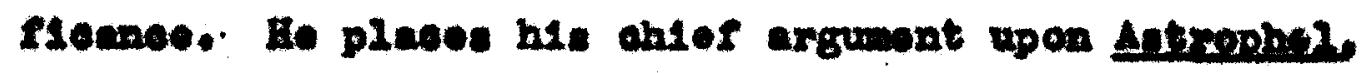
the goop of elegtes to inteh spencor was the ohter contributox. and throughout whioh stanoy's oelobre-

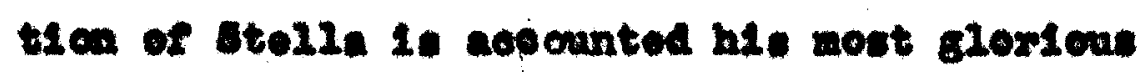

$\mathbf{2}$

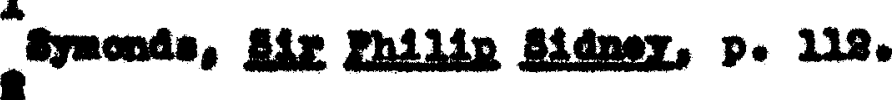

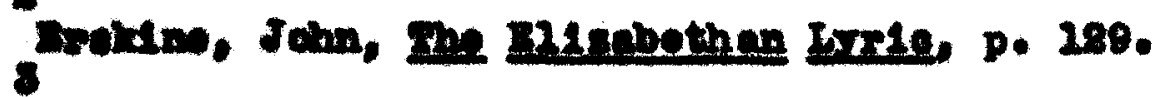

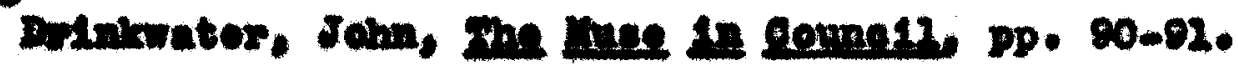




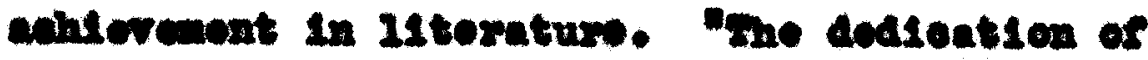

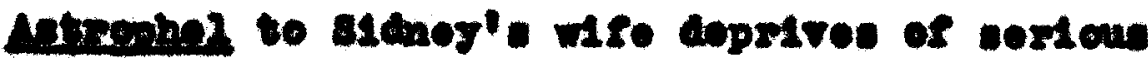

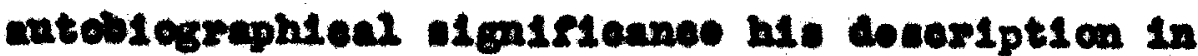
the comots of his purwat of atolid's affeotions." Fox Doures is al oo consinsed that the nomots are inninoere, and Indicates that sponser's colobratien of slanoj's pasel on for stella passes out of the realn of sober history hon we cone to - 2ator utanst in the porm and road that stolla,

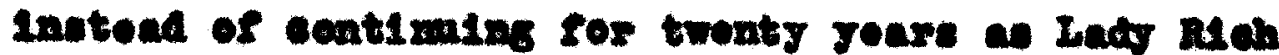
and onding hor ders as Countens of Dorcashire las w Imow that sho cotualig ald) toro horeelf in plecen over the dylag body of Aatrophel, Aying with ntil.

Thon there are the errtice tho consider sidnoy elnoese in Mis protestation of 20vo, but bellove mis $10 \%$ to be Flatonse. onsef or this ochool porhaps 1. Ix. J. B. Notohor.

1

200. Idinor. Mirrbethen Sonnete. Introd. x11. 8 Jou Bourno, B. 244. 8

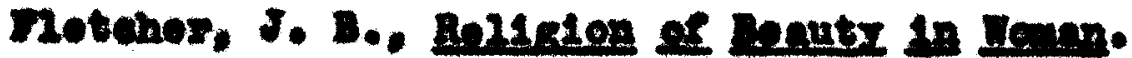




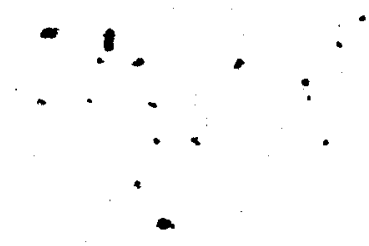

$$
-2 m
$$

Iow of the cenaste aro ecarontional,

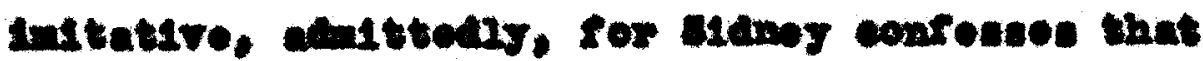
bo had spont his tim

"Oxt turnine othore' 20aves, to

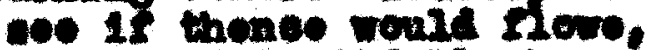

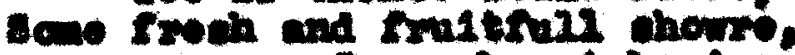

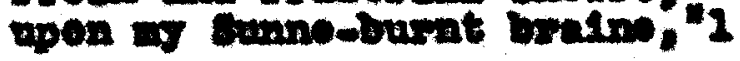

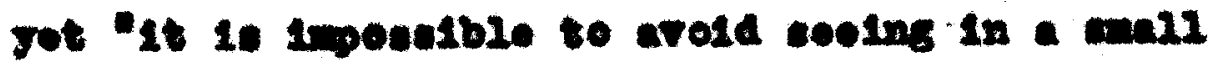

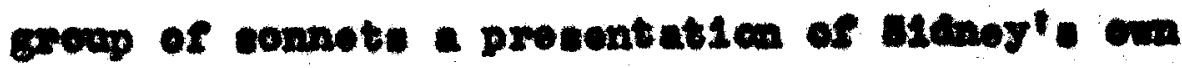

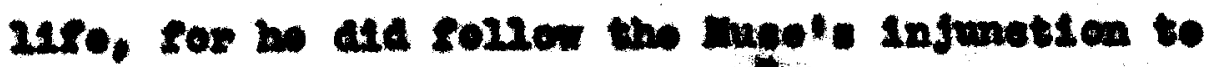

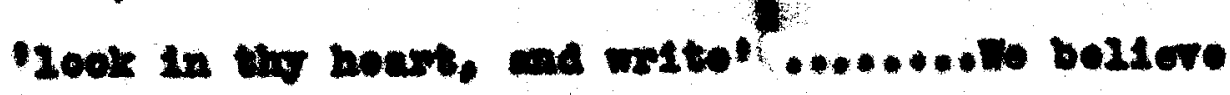
whe boeave and of the comote cquare exwetly

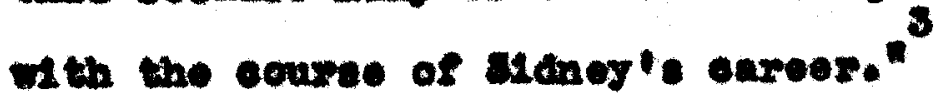

Cponser does oelobrate aldnog's 260 and homon sor

Gtolla the raire, the rairest otar in won theagh he does have to exwrolse the poot's proxogative and plees the corroct ondeng on his

1

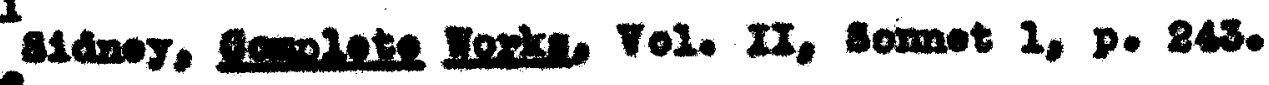

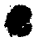
Midin, Fol. 2x, Beanet 2, p. 248.

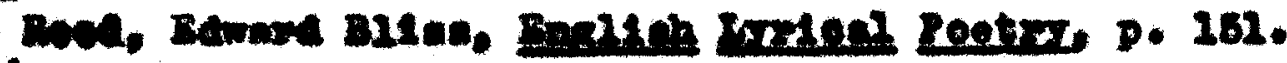
4 Epener. p. 700. 
paptegal olog by having stolla olay hostelf upea the dying bedy of Aotrophel. "Matthon Royden, in the seme group of elogtes, testiflos,

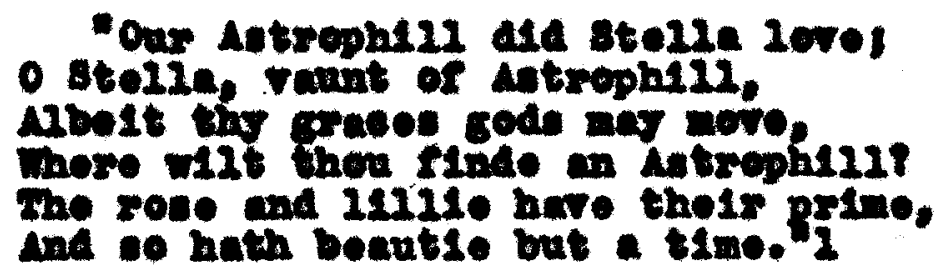

The "Astrophol and Stella" sorles was not printed unt11 1891, noasly 8170 joark aftos s1day's doath, but sene of then at 20ant, in opite of argumont to the contrary, wose froely el reulated in

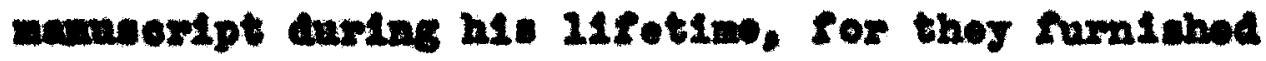
Mi. onder title to bo honoured at a poot mons hle contemperartes, and hozosed he wall. Iot, though

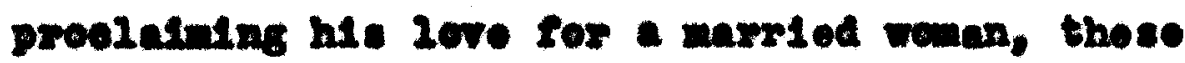
somet: did not secm to dotraot in tho loset frem hi. colobrated good charaetor. Yore then that, aftor hls death, a group of elegles lauding h1: 200 for stolla wore dedionted to his wleow. What kind of

\footnotetext{
1 Sponecer, p. 700. 8 vallace, p. 288.
} 
worle wa the Blisabothen Ingland

To bogin with, as Mx. Kotahor polnte

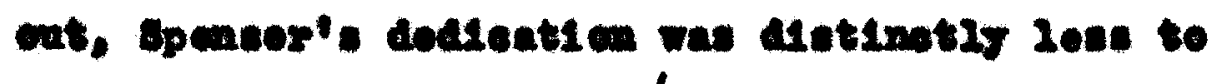
the weon of the doal sidnoy than to tho wifo of the Lifing Itesex, wese patreage the poot was at

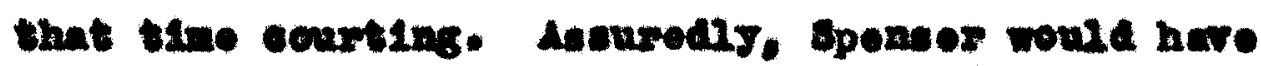

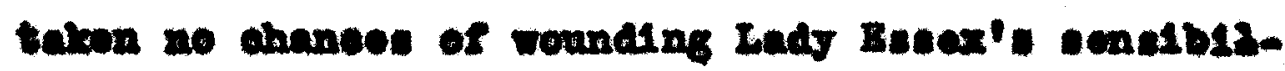
14les, and ni. Flotehor Loubte if an Bnglibhrenan werla have welecmed, oven in those were 'opacl ous eare' the Srank eolebration of nor late hubbun's

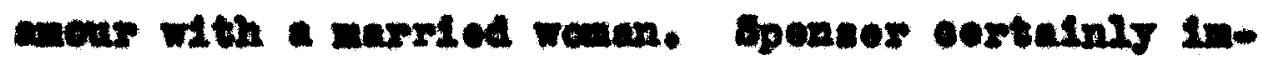
plles no marital inflellby.

And Jot, "sponer enge that Astrophol did 20ve Bte12a, but how Was there not a maner of loving roeogniged at the tine an oapable of alncontsy. won of forroney, and jot not in wodrock, and at121 not 1211 atti" ${ }^{2}$ Ios, Platonse $20 \%$.

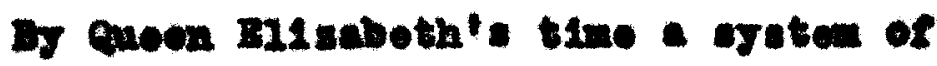

2 Motahos. p. 185. 


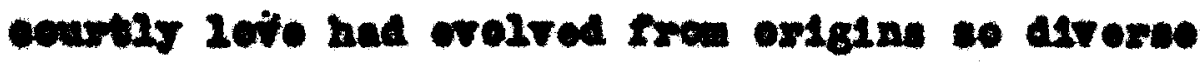
that it is matwed to mppose that the eoncrurreace of strome of incinence spont tho waters of thet peried would be rarlegated to the extrens. The begtminge aght be round in the Ax Araterls of

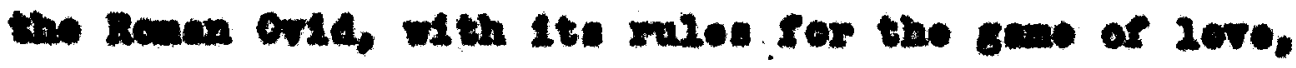
and in the coores of the Courte of Love wich oprant

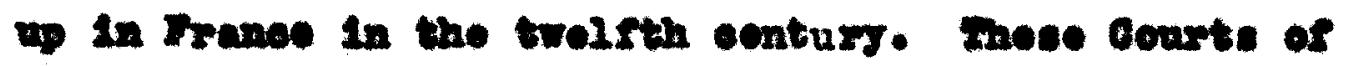

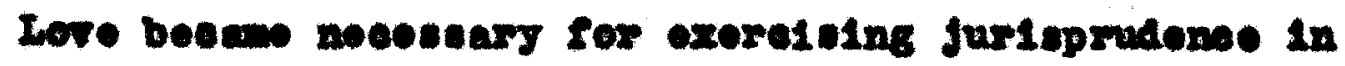

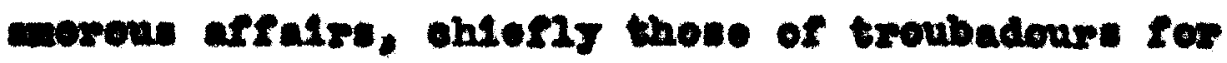
thols niatreases, who vore hien-born Iadios probably narrice te bubbede mach oldor than thog. The songe when those troubadowre sang to their nistresses wore frandy inowal, and oned tholr growth to a coxrupt cendition of sodety. Marriage anong the higher

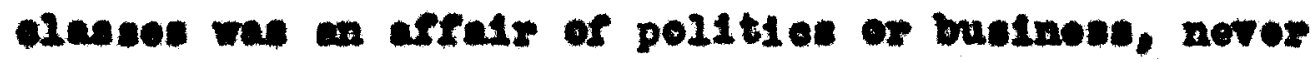
of the hoort, and 1 t becane $a$ doetrine that 1070 and natrimex wore incempatible. Leve there mut be,

1

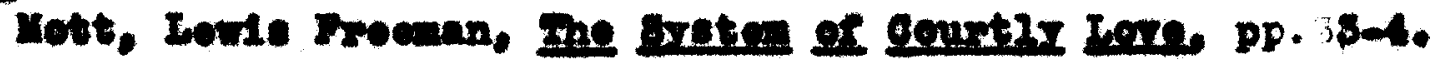


sevording to the dietates of the Gourts, and

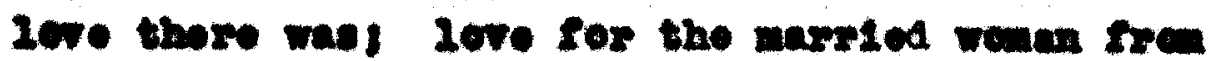
the wex who wal not ber buband."

Tris wa medievalien in Franeo, bat " anoas the Itarime of the thirtoonth eantury the rovival of antique Ilteretwe we is sull mang."

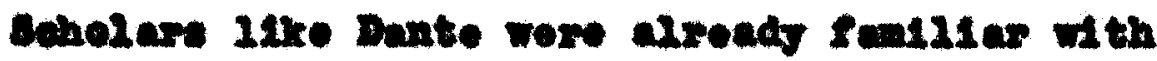

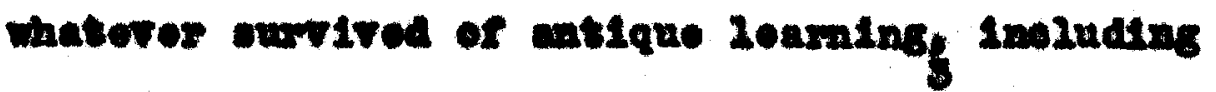
the tranceondontel theories of Plato. Indoed, from

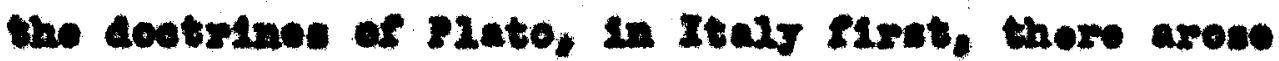
a ner. re11gten - "the Alfine rorahip of benty, and

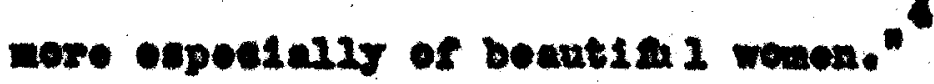

Potraruh, wore than Dente, is tho keg to the 21toray awoknteg of bagland. Io unltes the throud of the anelent roold and the medieral, P2o-

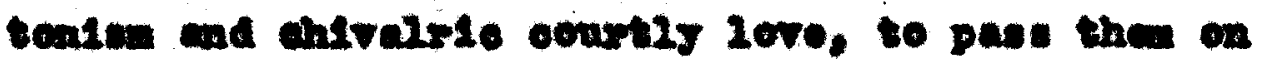

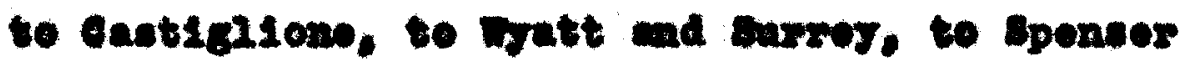

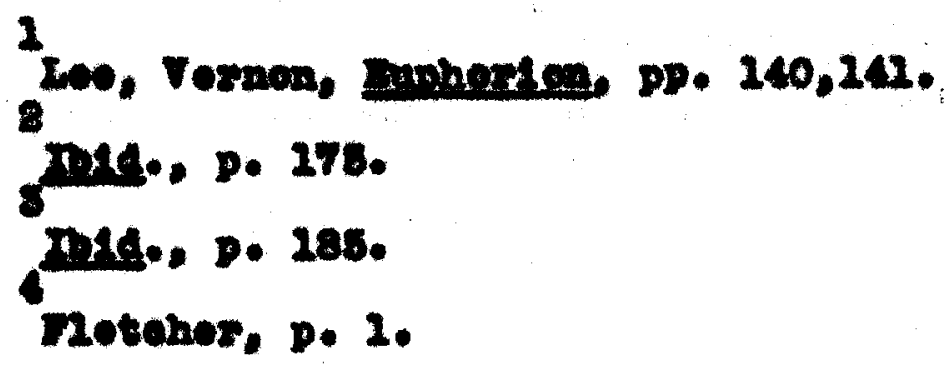

2 Iov. Fernon, Enhates, pp. 140,21. 8 D.t. D. 278. T18. p. 285. Rotenos. p. 2. 
. andars.

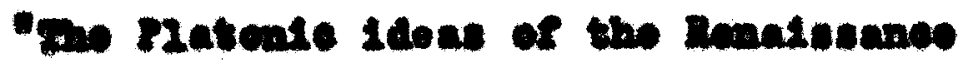

cens Irom Italy to Ingland not only through Po-

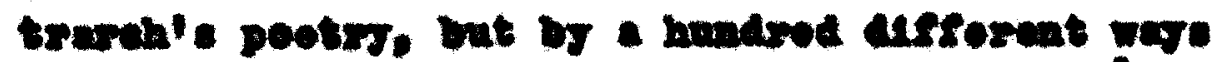

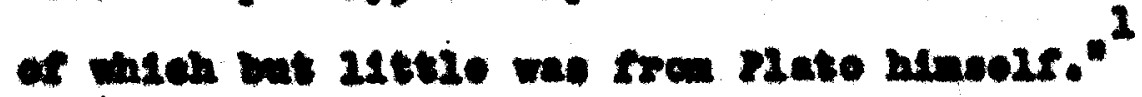

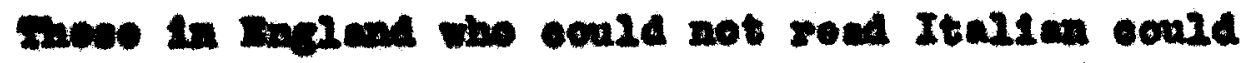

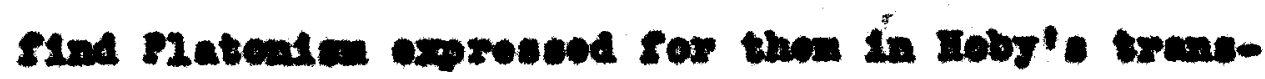

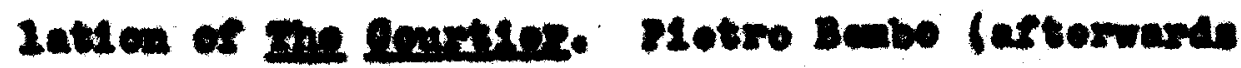

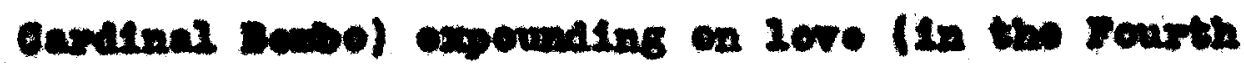

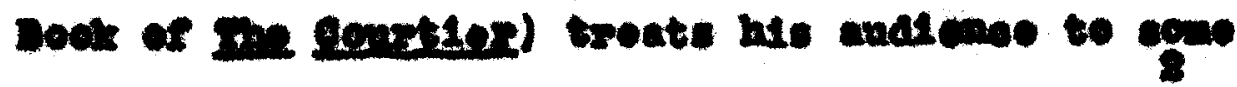

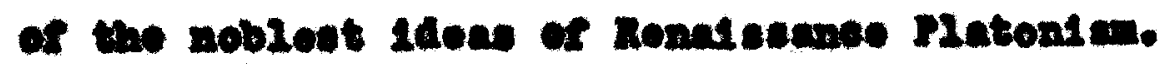

Iove is nothins oleo but a cortaln cereting te onjor bocutse." (p.308).

trere, we 122 torm it an innuones of the hoaroniy bount1sulveses, tho whioh for all it borotenot th ope ali thinge that bo exosted (p. so4).

chore sentuall $10 \%$ in wor ace is munght, jot in jous pon It doserveth exouse, and per-

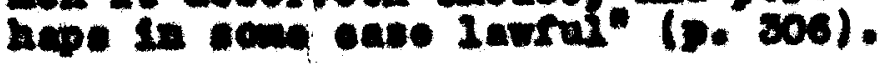

"I say thet bonut10 ocmoth or tod, and lo I1ke a elrele of goodnobes inoreor is the contre.

2

minoteln, p. 85. 8

gavted cano, p. 208 Rf. 
And therorore, as thow sen

be ne arroie ithent a contres. no pore on bosutse bo at thed coodnoseo." (pP. $808-500)$.

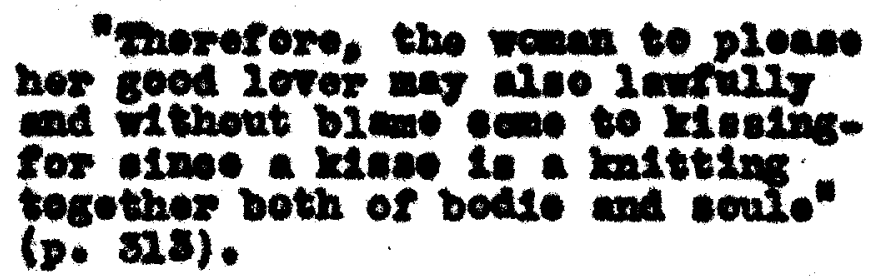

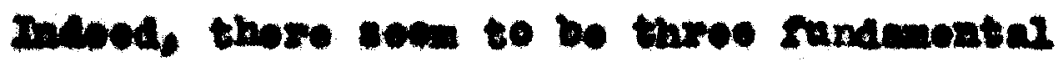

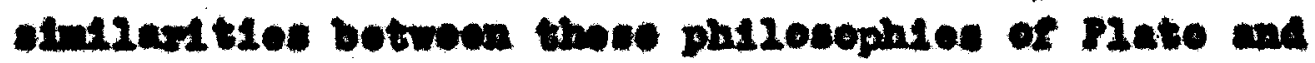

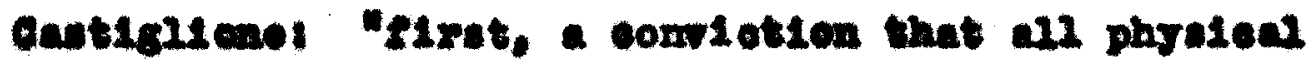
forme ere but tho shadoringe of opirttual realitions

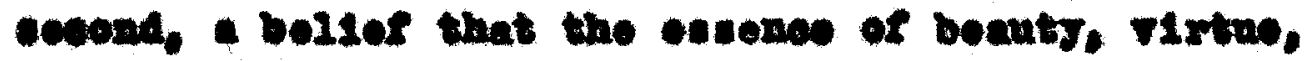

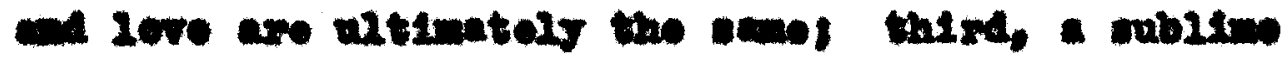

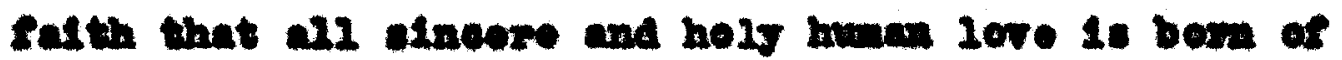

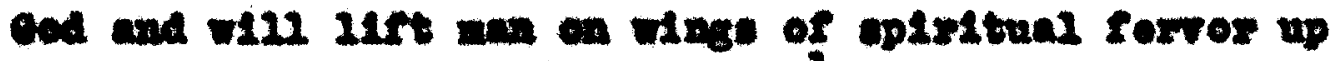
to the granders of inmortulity. ${ }^{2}$

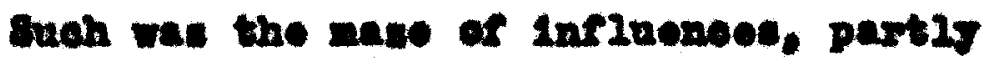
Platente and partly the roverse, breught to play upen

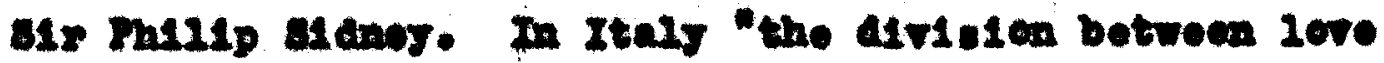

1

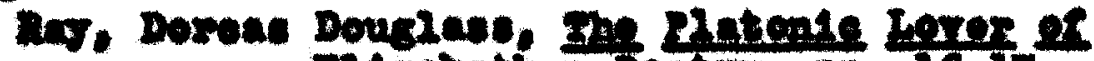

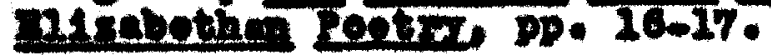




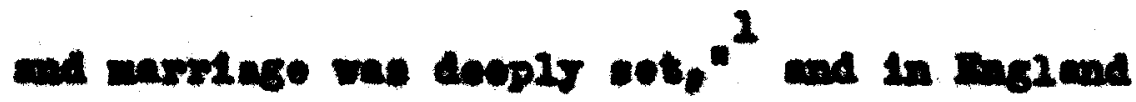

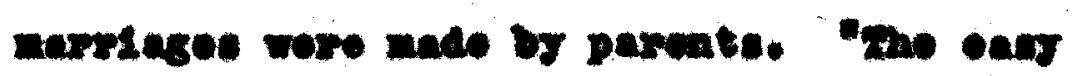
worelst of the elxteanth eontury allowed wo

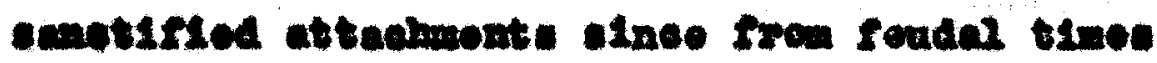
the nomalesence had inhorited a cefforenes in noanks botwen the words "Ierer" and "mobend".

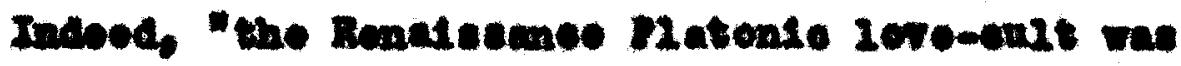

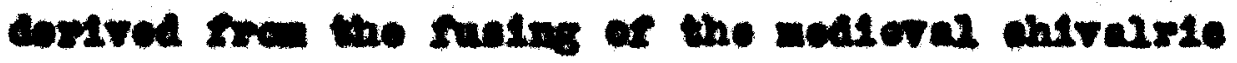

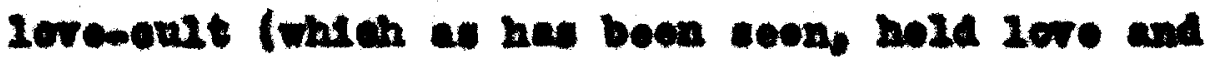
anriege ineamatibie) and Matoule propos.

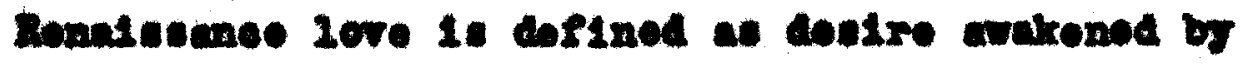
boantr. witen by progrecestre lilumination passes

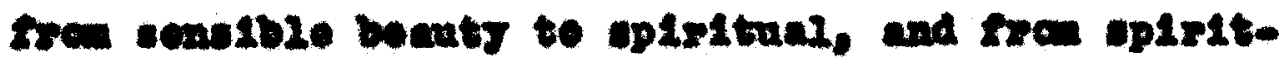

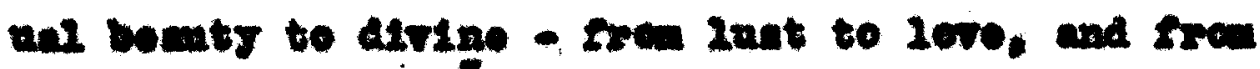
1eve to pulleten."

I. the 11ght of woh doctrin, reasone

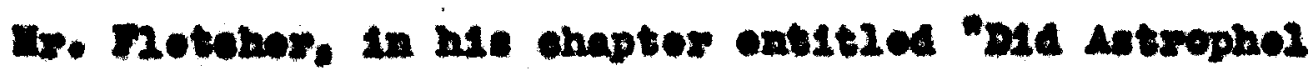

1 zaror. $\mathrm{p} \cdot \mathrm{100}$ 8

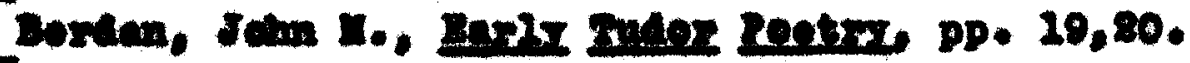
3 notanos, pp. 184-286. 


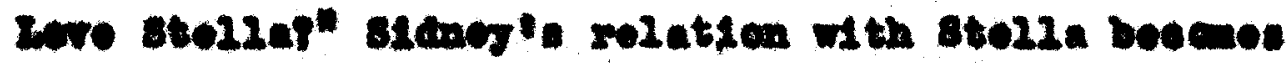

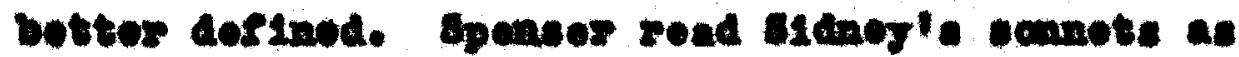
opreselea of vare platende love, hold 11elt to-

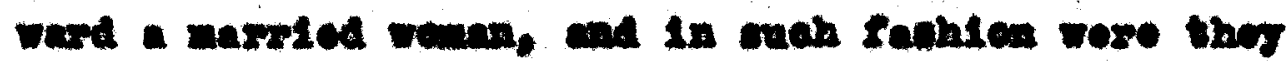
widentily rocetred by all concerach.

As has bow seon, Castiglieno roquired

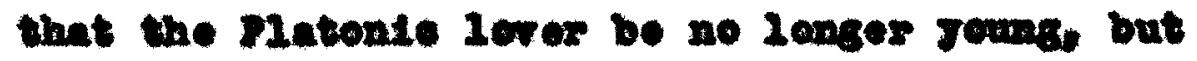
conmal 2070 he cousteored excuncble in gouth, and

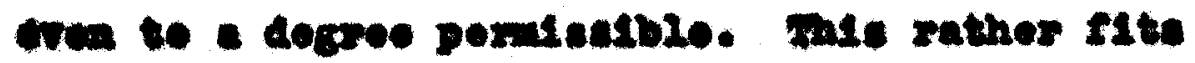

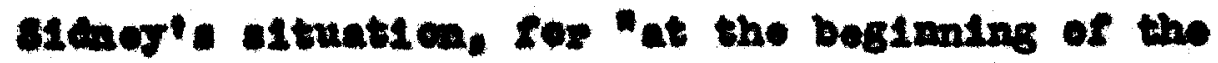
seunote" ho "noes the botter, get eannot but follem

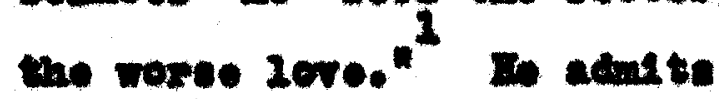

Gant my ome metelnge 24ke bed ecreate shem

is Fits, quiek in valne thoughts, in rextue Inas:

whet Plate I hare med for noaght. bet if ho twae

wah coltioh yoares that to iring $x$

mobies costros ..... (somot 82$)$

Io tolle hingels that pirtue and bockty ase ono

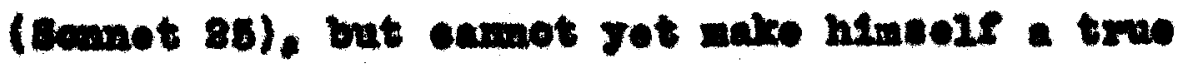

1

Rotuhor, D. 207. 
bellover, and oxles out:

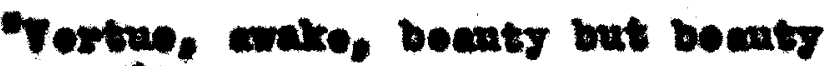
181

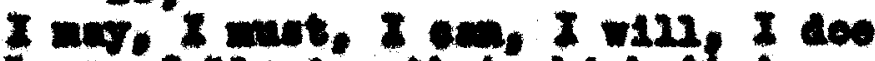

roave coulowing that wion it is gaine to alsec." (Bomet it).

stalle pretes the brath of the pratenle coneopt that Virtuo and Doenty are on, for hor phyeleal chame woesd wth hor noble boharior. Iot in

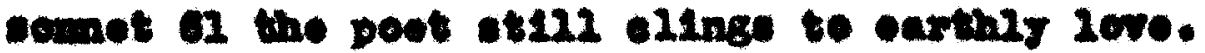
creduni2y, howeror, his robellien pasece, and bo beecen more enbelucht

Dostro, though thon wa cempanion art.

And oft to elingen to wo pare Sowel that 1

bas fren the chor soureoly om conor.

mile oah wo blewe the flor ar - ants

Iow stru th fellowhip I abodos mant part."

- * * * *

Borvice and honour, wondor with exidht.

Ioam to offond, woll worthy to appense:

coro thening in wine ores, falth in a oright.

whose thinges ero 20 th no by envis dowe" (seanes 78). 
As sward for the obeerranee of "those thinges". the owermontel k10 is brtowod,

o kibies mich soulos oron gorizen tegothor tieg

Dy Iintos of Iore....." (Bomet 81).

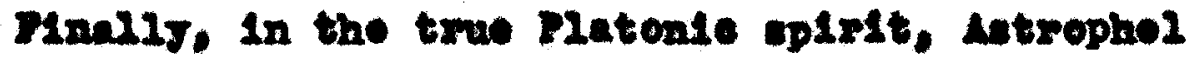
Ifes above the lewe of mortal boauty to the 207e of the alrine "elemonta" thomedres of beauty in God. ${ }^{1}$ the last nomet in the veriof, bogtanding

$$
\begin{aligned}
& \text { "Inare wo Lere, which reacheat } \\
& \text { but to dust: } \\
& \text { and then wind aptre to } \\
& \text { mener thinge, "8 }
\end{aligned}
$$

marke the find ond of the otrugeles agelnot carthly donlro, and the gloxicas triumph of Plam tonle 10re. In this 11sent, Mr. Fioteher thinks

2 Netahor, p. 161. 8

The is not inoluded by Foullierat in his -ateion as a part of the "Lotrophel and stella" ser1os, but a a toortaln sonot (IX, 382). ono that is properiy disuoointed from the bequonce to indicate an undeterminod period during wion the tranaltion in the loror's att1tude took plese (Tal., 258). 
thrt stengy was the "right courtiog" of Gab-

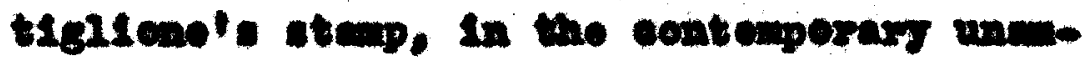

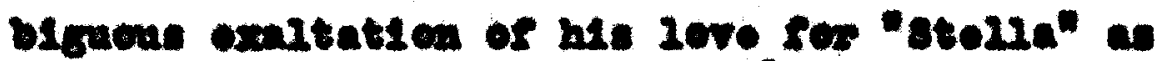

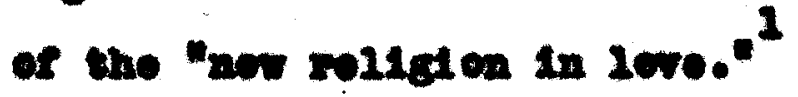

If 15 vore poselble te doabt the Matenten of the nemote, wh Anelle could

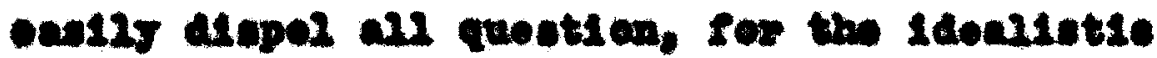
prinatplos of plateale love are riable always In 2te pages, Bandive cemplaing that now

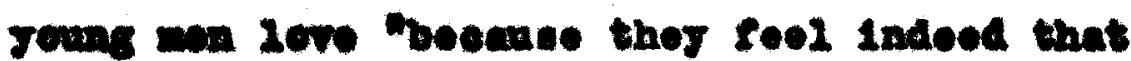
Afino power, which akkes the hoart finde a reasen in pestion." ${ }^{2}$ no volces Bembots bolles that the zeve of oxa age is beat." Anothor character. "(though he wore alroady atept inte the wintor of his age) found hingelfe warne in those doctres, which ware in his seme farro

1 Hotehor, p. 164. 8 ge. 14., wher I, po 90. IN.. Has II, p. 240. 


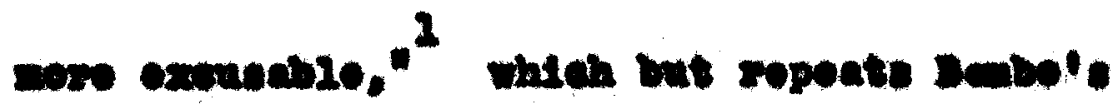
otatement that phreleal dosires are nore ar cuncble in jouth.

2 g. At., Hber D, p. 24. 


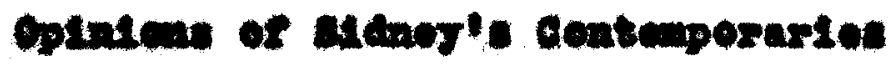




\section{Oraxt

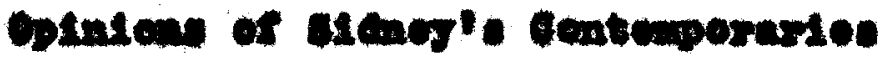

Nowre ocre that the pratwe of 84

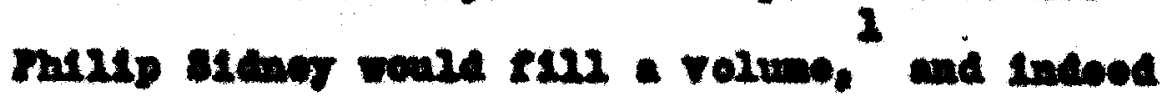
18 18 tres. Inat wero the poouller tratte of

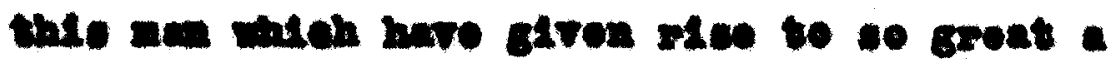

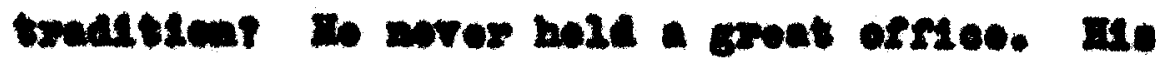

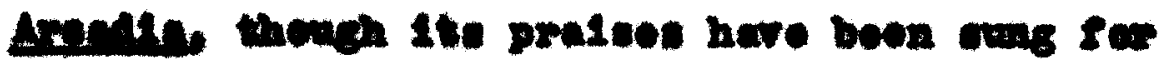

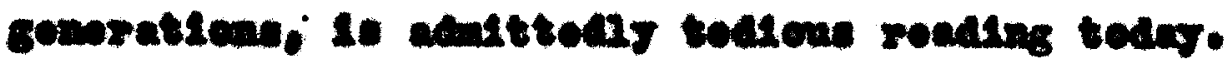
Dron the comets, Inpoptant as thoy ars, aro mo-

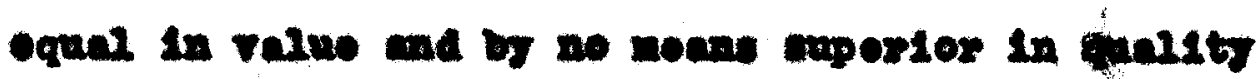

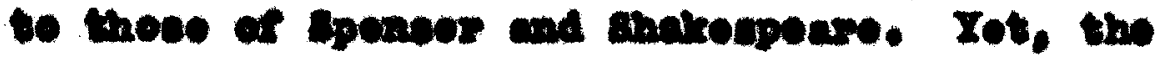

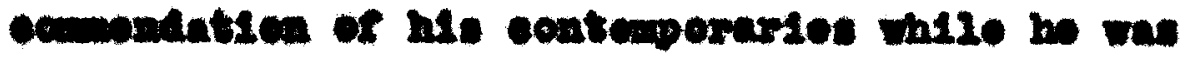

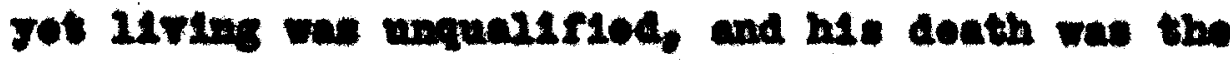

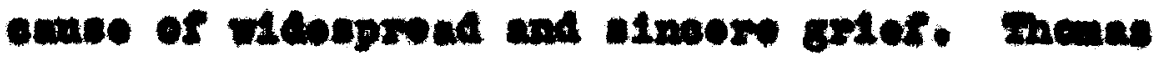

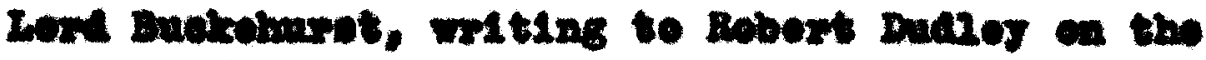

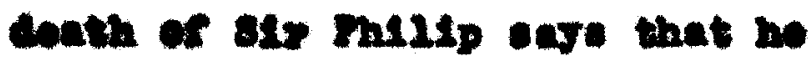

2

Peare, Introd., Irodil. 
Both 217ed and aled, in 7ono or Eonour and Roputation to his Imo. In the vorthy sorriee of his Pringe and Oounteri wa with an groat Love

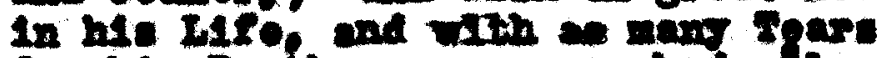
for his Doalh as over ang had. 1

collins also reoordas

- Co genoral was the Inementition for $\mathrm{him}$, that, for wap Hoathe artor. It was becounted indooont for an cuntienen of conelity to appocer at court or 61ty, in any light or gandy appare1." 2

Perhape the following is a olue to the great honor in wioh he was hold

"His noblo and gonorous Dipoattion to re21070 all who wore in D10tress, appoare srem opreral Instanese, at wil as frem his Letteres and ho was co univeranily appl muded for 16, that hie Fene oprosed oven beyond the Bounds of Europe. 's

At no portad of ble 11fe are rocorde wanting of nots of grasions kindrinose of intercossion for those who are distreased.... It was to

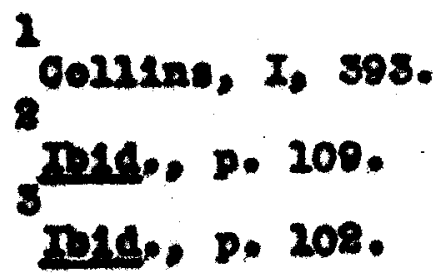




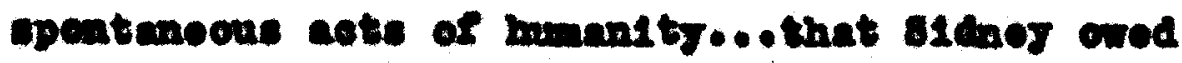
In creat mearux tho 2070 and adulratton when wore poured upen hel by all olasese of hlo sountry.

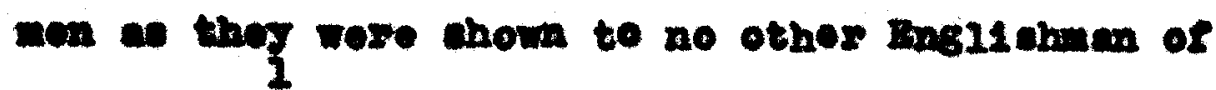
his t1mo." It $\mathbf{1 1 2 1}$ be sumembered thet one of the -arlient recordod nate or bldnoy won a sohoelbey was his ordering his corvant to glve a onsizing to a blind haper. It noene that oren in the aldat of his and notivitios he was nover too bus to holp the oppressed and porerty-itriekon, and at

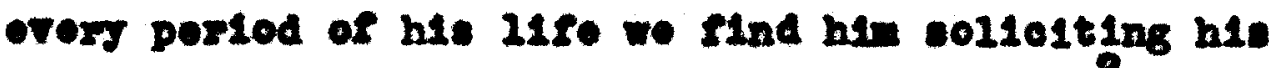
Imelnential friende in bohale of the mombie." In rogard to hls patronago of poer witers, John Budge the booknellor, in 1618, sald, "Roport del17ore of the nowowned aldiey that the wost unflied worke the poorset hand oould offer up, woe reoolved wth thanke nakdig the $20 \%$ of the men to cupply tho

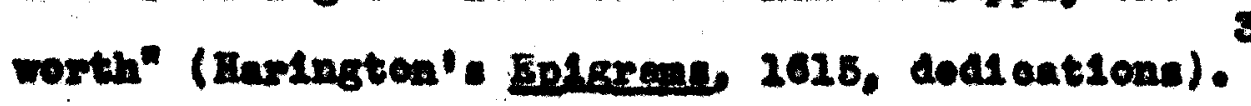

1 wallaee, Whe pp. $887-288$. 8 In11., pp. 200, 204, 375.

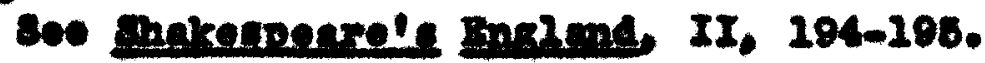


Iowerer, he was not arware in the Ifent, and this leat, together with his impotuous Indinese and genoronity. poxheps axplatno meat eat1efaotorily the appoal that ho made, for an hore toe neasly porfeot would have grated upon the sonelblilties of his more hum brothore in tho Ellsabothon dee an moh as now.

80 was hot-hoadedly quidr in making doolesion about pooplo, and often harah in exitio1en. Opon on cecaston, during his forelen travel, ho unfustly secused one Conlngoby of taking some mones. Sor he writes Innguot Irom Vonice.

"As to the menes which the took

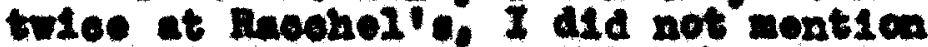
1t to give jou any trouble, but onls

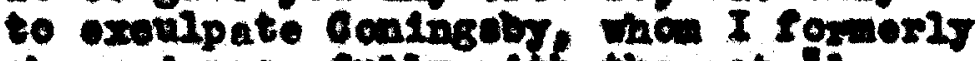
onerged weongtuils with the act."I

At another time ho ranhly threatene to thrust h1s Anger into Mollinovx, his fathor's meeretary, bocanse ho thinks that the latter has dirulged the contente of sone of hls om letters. Purther

\footnotetext{
1 Pearu. D. D. 8 col11n, I, 800.
} 
nowees wors bo 2 odged who bo was eont ebread as a Apzenatie abaseador of the cmoon. It roades

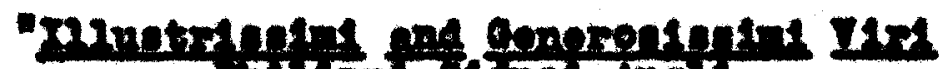

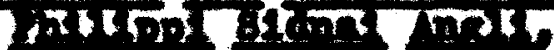

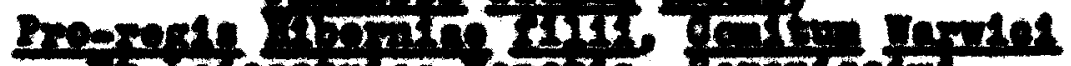

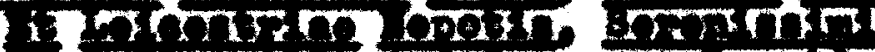

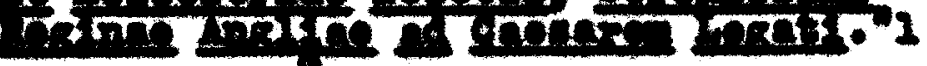

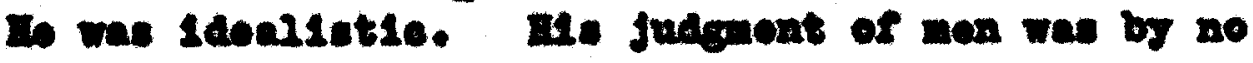
moan profornd, and it is deappolnting to learn of

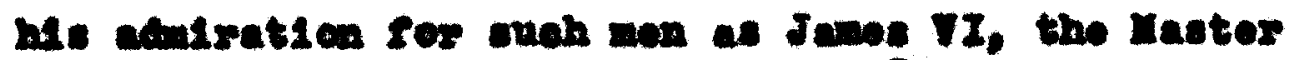

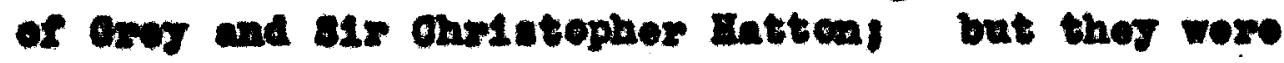
temperarily preminont, and slenoy was a child of the

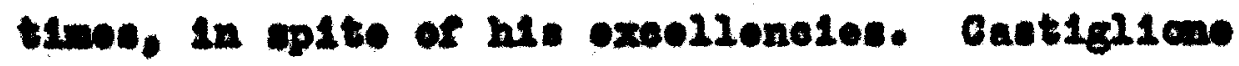
woule heve Mie courtier mate friende of wom noble and of great roputation, and s1dnoy doen not depart sran his plen.

Io wan gonprowe to a Iavit - se mach to that ho was continualiy in Inanolal alffionltiol.

2

coll1ns, I, 100.

8

nalaen, Ites, po 367. 8

I.14.. P. 380.

Casterione, D. 280. 
Dobt coems to hare beos hit astiduous ecupanten throughont his 21fotsme, and though be ded at Armati en ootebor $27,1886,{ }^{2}$ his bustal ate not teke plaes mat1 Fobrany 26, 1887 because of the inniutont anand of his areditore, and the Inability of walatughen and ioleoster to moet his obligatione 1.modiatery.

In opite of ecmondatione to tho contrary. he wa not "oplest wthent biot" got the manyaldednose of his abreoter, his ablitty and his unifue chare sot hin apart, at the sributes of his contemporasies w 121 tostify.

Grovil10 is partiealarly sluent in his coeount of the praices heaped upen sleney mon, at bronty-three, he was sont by the green to Germang and the Iow countrien on a Alplematie miselon. Io was 20rt free to confor with any prinees with whom 1 t somed expodicnt that be so do, for oncouraglng unica

1 Tor Bonino, p. 360 . 8 ssmende, Ire of sionor. D. 118. 


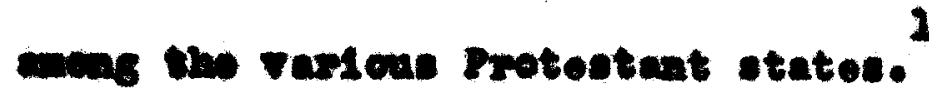
w211en of lasoan. Pripes of cronge.

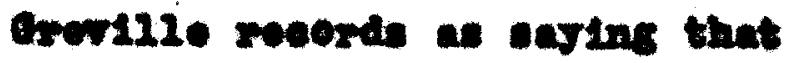

- If ho coula judge, nor unjosts hed tas of the Alpopt, and groat-

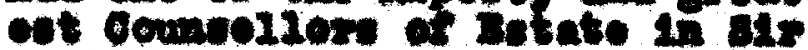
milip 81enor. thit at the aty ured in Barope. 8

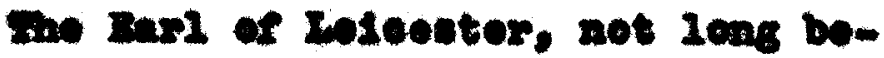

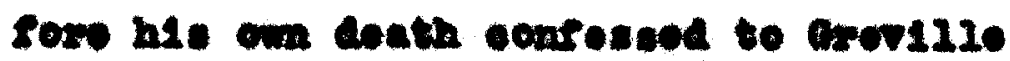

-that won ho undertook the corerrmate of the ber countrios

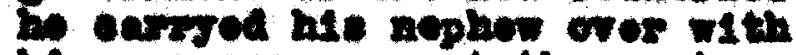
hin, as ons moaget the roet. not ons dopplating his roubh for - Comnollor. but withall bearing a hon wor hin as a forward jouns nen. Iotint thetanding, in whort

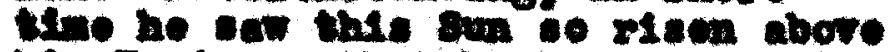
hio Iorison, that both bs and ell his stare wore gled to Poten IIght trom nim." 8

81r Franele Welalighm, S1dnor's Sathorin-2ar, aleo often told erovizu

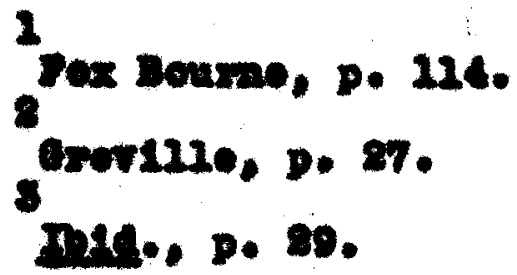


"that he milip do ne far orero choot hiv in hil om Bors as

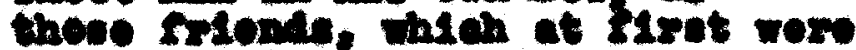
815 rusis's tor this Eoonotaries sake, Ithin a while boente ce ruily crmod, and poseost of alr millp, at gew ho hold the at the socond hind, of his cen-in-10we native courteale." 1

Irkowtse, Dears of Franee, than

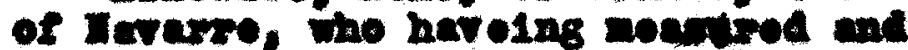

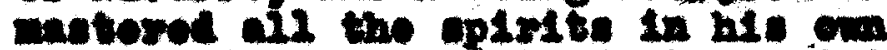
Intien, foond out his unotor-opirit Eares us, and used hin lito on equall in nature. and wo fit for friondindp ith a ring." 8

Pulnet Den Jobn of Austria, who at siret treated staner with sene havteur as a more jouth, seon, arter teking acoount of hin,

"foma himeals 10 etriaken with this extraordinary Pianot, that tho boholdere vondered to neo wat incomous tribute that brave and hipen inded pisies pald to his worth. of

Bren Inodesa his onem colmonledgod

openty

"ruat hownower he wa gled Iing

1 envil10, p. 30. 8 I.4. 8 214.. p. 80. 
M2149 his noitor had 200t. In a private Conticuan, a Angorval Inex to his zutates rot he could not but Imont to too Onriatondane coprived of of rame a Light in those oloudy timot and boweli poos ander Ingland -0 that bering boon and

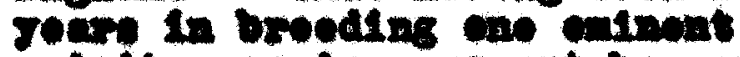
oplats, was in a menont beroeved of ming of the hande of a vilieln." 2

Crovil2o hinsolf pajs tribute te he

fread in waw poses, and cemonts that his groat-

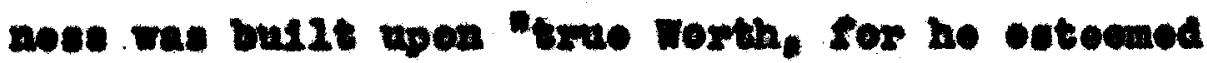

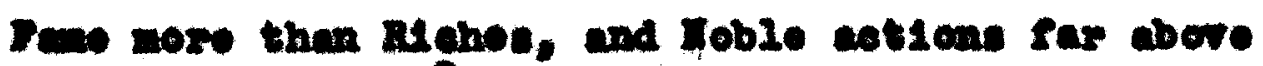
Iobluty 1twole." the groatest tribute that ho could have pald stende elear upon his own momanont heweror. Lubreg relates that

In at. Mary's eluwah at Warwiak

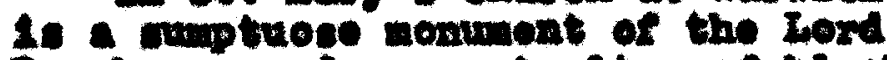
Broeke. Fowa a great altar of biaox atrio is only this incoription!

Inore 210 the body of

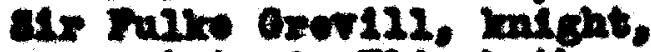
vowant to Q. BIIsaboth. councel2or to Xo Jones, and friend to ais Philip bionos."ing

1

Crov1110, pp. 88-38.

8 2019.8. 88. mbers. D. 980. 


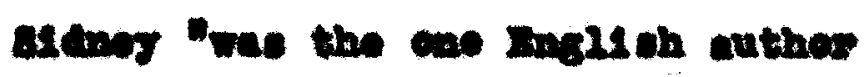
of h1s tine tho hed a Buxopean reputatical Ba Dartas, for Inotmase, some jeare later," in his

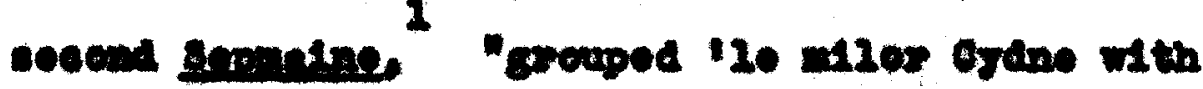

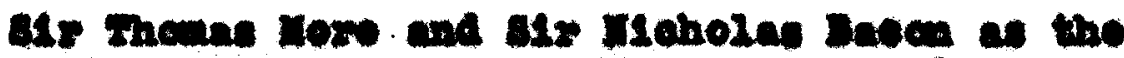
throe plliere of the Inglien opookn,"

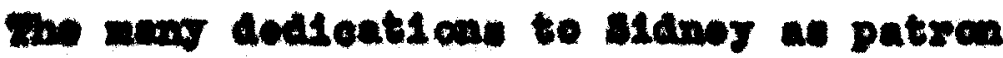

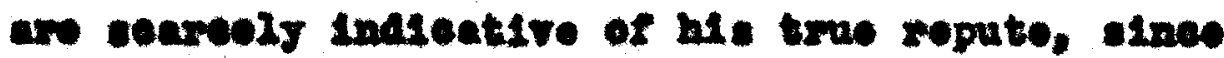
2t was the buanose of the otrugeising athor to

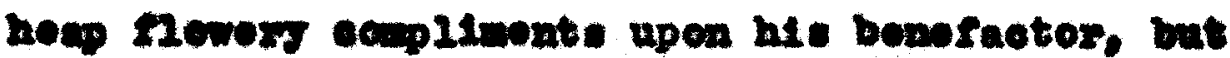
the max types of books dodiseted to him are a 20

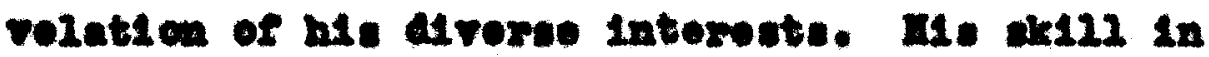
ane polnted hin out as the patren of Ilcholas

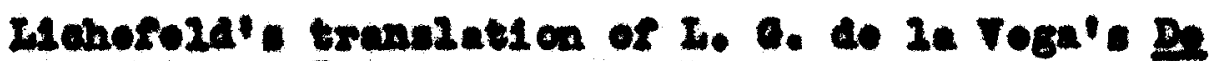

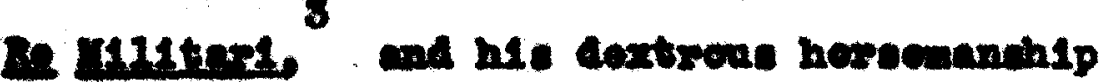

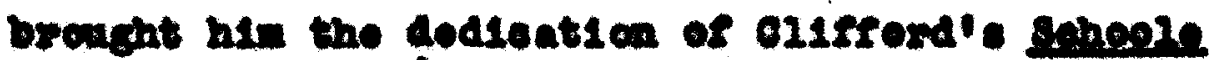

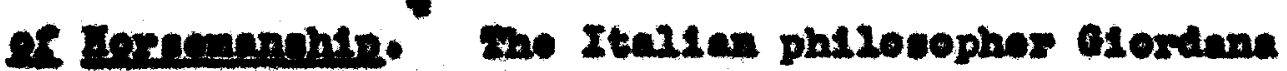

2

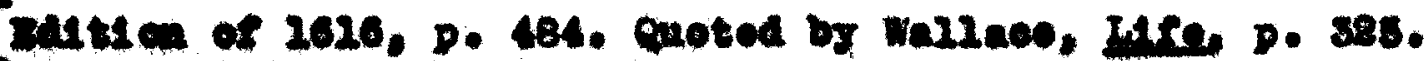
8 moterontein Engend, $\mathrm{II}, 108$. 8 M14.. 2x, 208 .

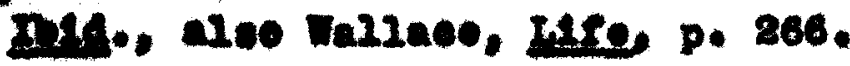




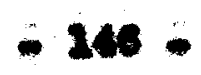

Drumo wes he friond, and Innortbod two of his vorte to $\mathrm{nt}$.

Ioxt In Inportance perheps to Epennex's

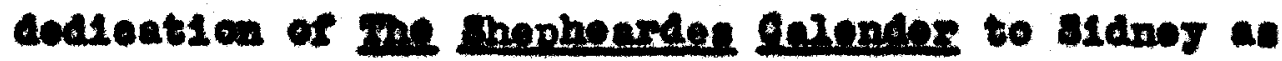
the noble and rextuone gentieman nost worthy of al t1t10e both of leaming and choralrion is

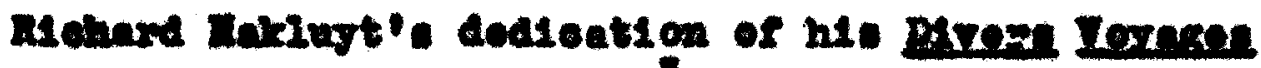
to hie old eolloge triend.

tranguot's pratses of his joung protege are of course protuse, and collins in his profase

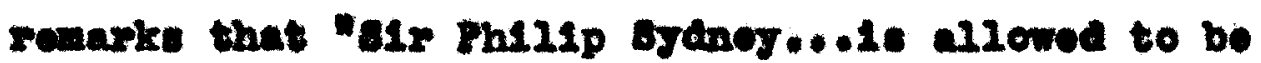
at aocouplishod a Oharacter as this Int1on, or, porhape eny lorelgn ane, orer produced," the thinke 1t genariable that thore are exact parallels of the femede stenoge wengst the ohlef of the Romanes

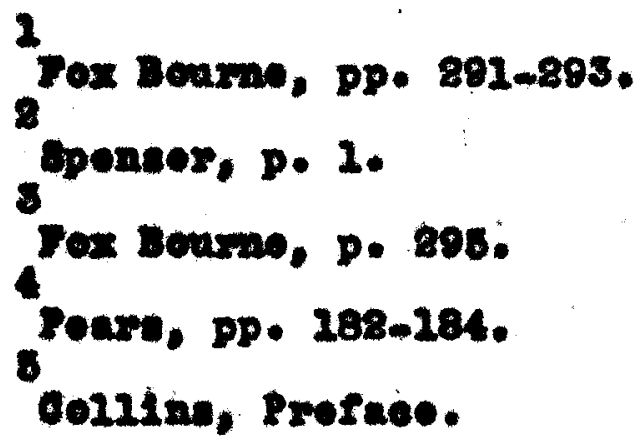


In 41. Ph111p 81dnoy. w bohold Maroeline and Iotaona unted, who, with tho atrongent Blequebe could at enes teach tho best mise of pootry and nost galientis and bountisulis rewarded Ion of Iottere and

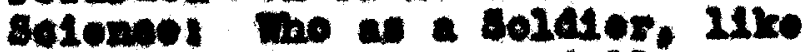
7. Doelus ins. Baceegarulif oxom cuted the ontiont Bizonos in

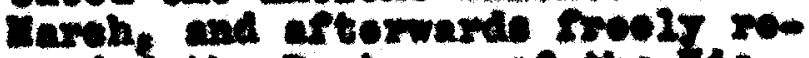
wardod the Vartions of the I16tory out of his own puree and aro, Ilro Deeins, covetod hin sole in Dattio to his countar." 1

It Is uneesesary to eatnlogue tho

raet wuber of pratees and Lmentation rolecd

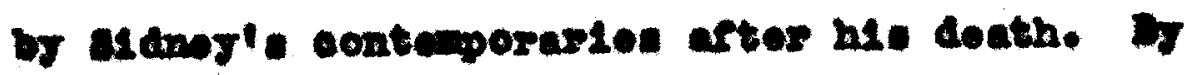
soes otrange prank of Fate, no momunont in steno

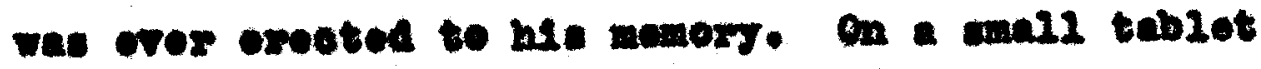
of weed wes reoered this tributel

Huglend, Wothorlond, the Heaven and the Ant:

wa Bouldere, wat the Nor2d hath uade etx Barte

of boble blaney! for who $\mathbf{w 1 1}$ cuppose

Thnt e trall Inape of stonos ean alaney exelose.

1

coulas, Proface. 
melend has his Body, for the $2 t$ rod,

Iothoriand he Dload, in hor Dofones oboi:

the Ieaven have his $80 u$, the Arte hove his Fine.

we seurdiers the Gxiof, the world his geod nowe." 1

Pexhepe of all those who bowalled

the lose of an honored frlond, none voleod a

nore oxaltod sontimont then ald w1111E ondon:

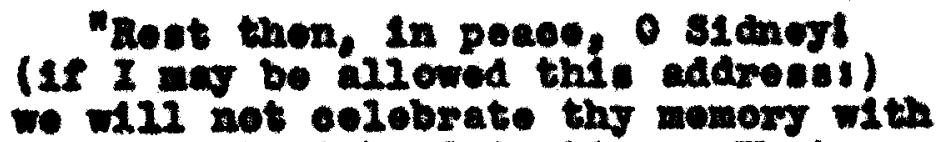
teare, but with adiniration. Whatores wo Iered in theo las the best of Authore apeaks of that best covernous of Britein) whatorer to admir'd in theo, continues, and w1I continue in the vecuorien of mon, the rovolutions of ages and the annile of time. Mang. as ingloxiour and 1gnobio, axe bury'd in oblivion; but sidnog ondil 127 to 12 posterity. For, w the Orook poot has it. IIrtug' berond the renes of

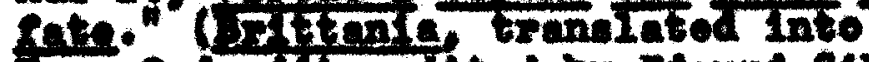

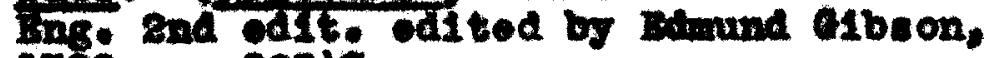
1728, p. 225)

\section{1}

collen, I, 109, alno Ambrey, p. 860. 8

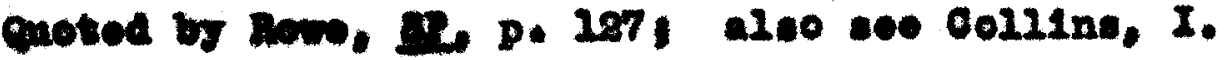


Conolusion 
Cenoluet on

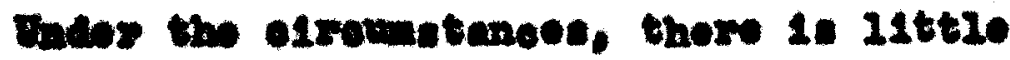
thech oan bo seld in way of coneluelox, for Itwo.

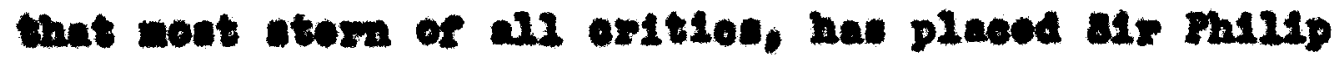
stenoy in tho amala of those coparted onot who jot 217e. In an age of trangdtion to now klnd of 1iving, ho was able to plek up the thread of 2180

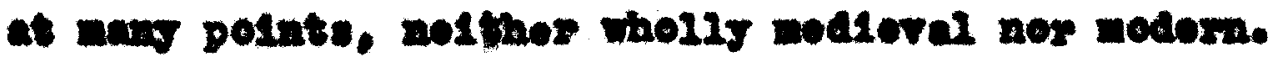
In slency his centemporarios "as, the rouleth of the

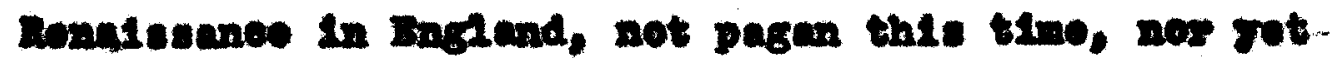

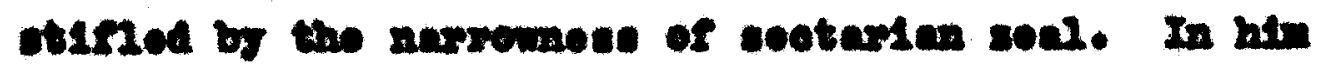

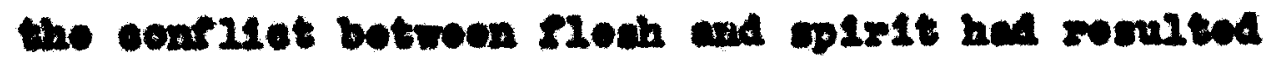
withor in frank paganlan noy in cour roprosetion of the natural and. The intognity of his oharacter

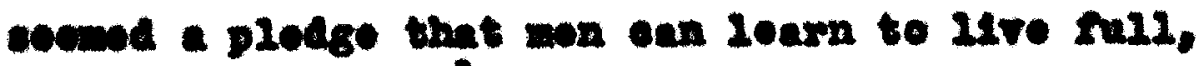
unteryins 21 res."

It It Impenalbie for ne of today to pat car elngere upon the oxnot qualit1es which ondoared

2

Wurlase, "Ropatation of 81anor," pp. 11-12. 


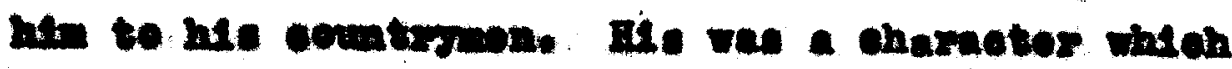

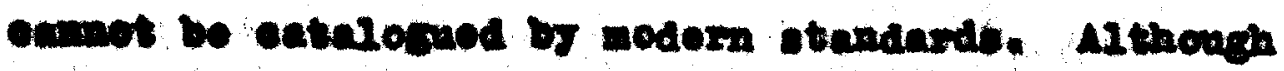

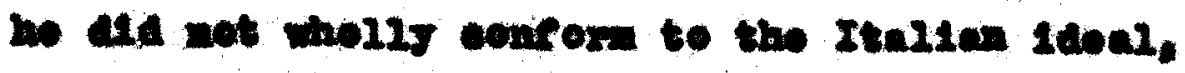

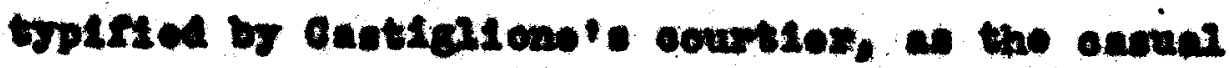

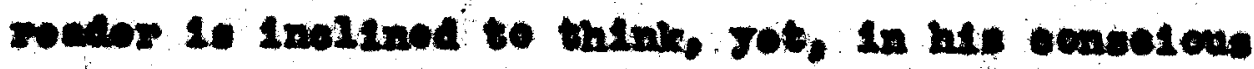

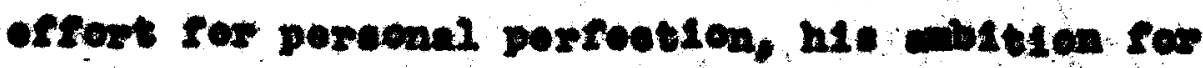

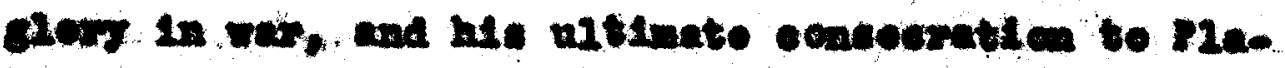

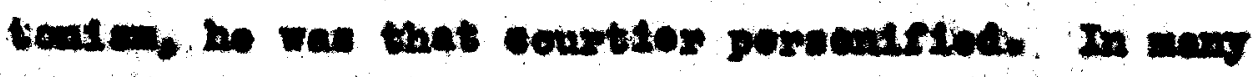

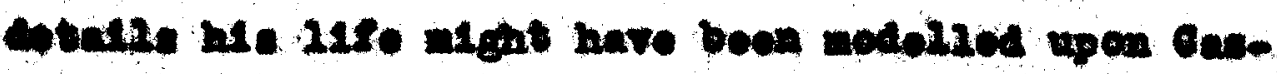

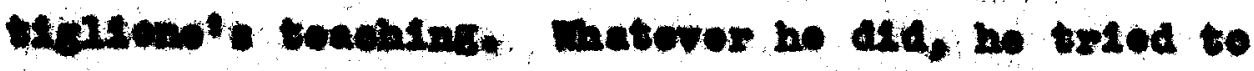

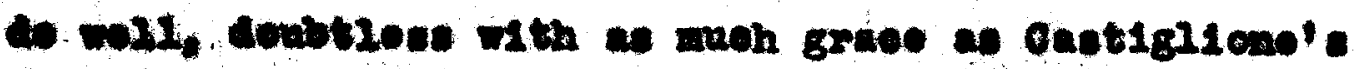

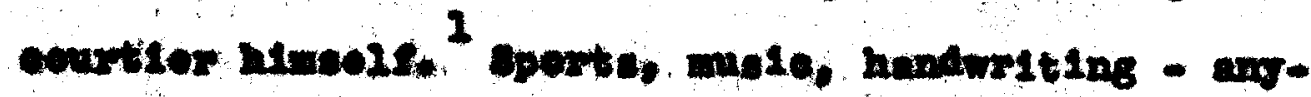
thins vat the boit he consldered falluro. Ho "oxor-

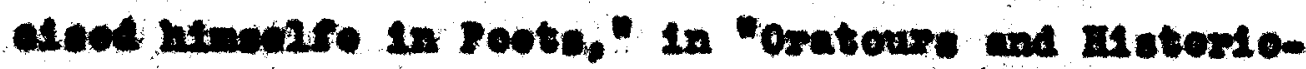

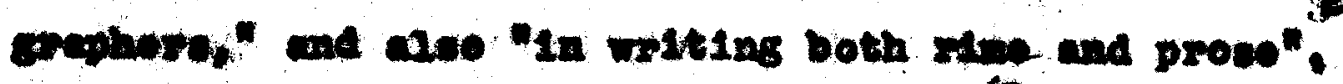

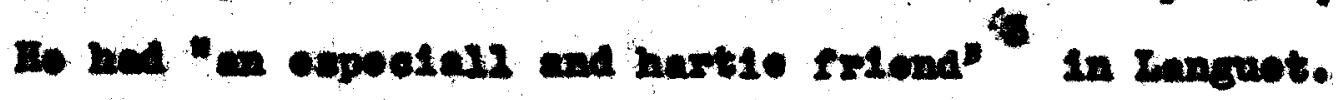

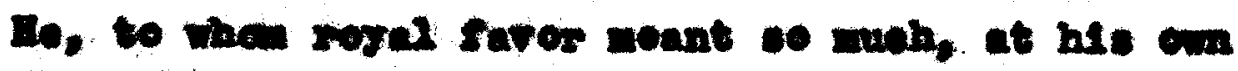

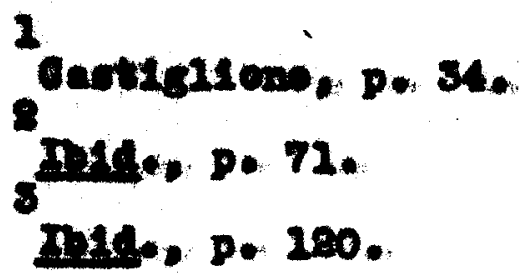




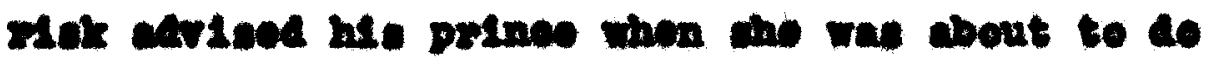

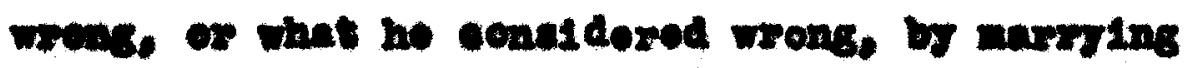

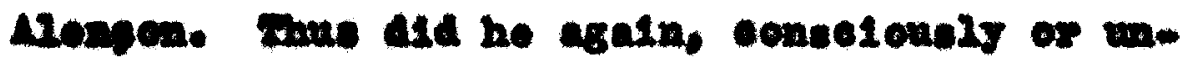

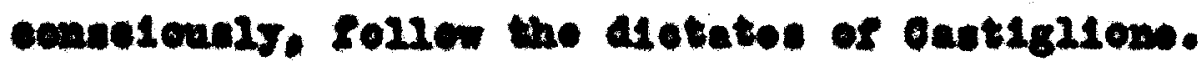

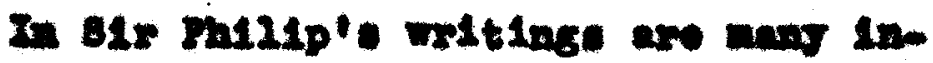

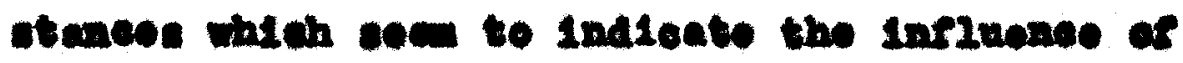

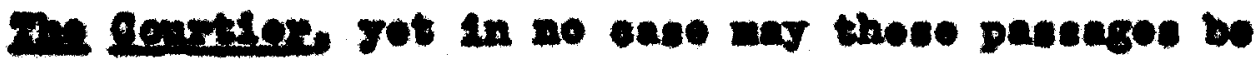

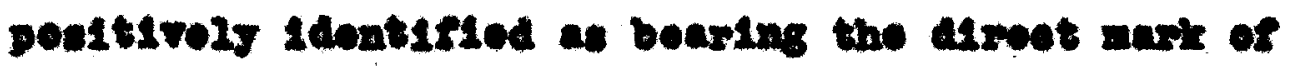

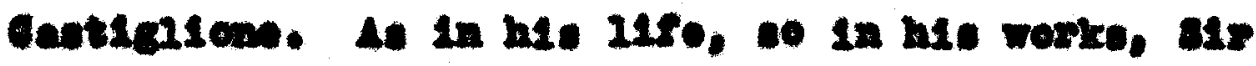

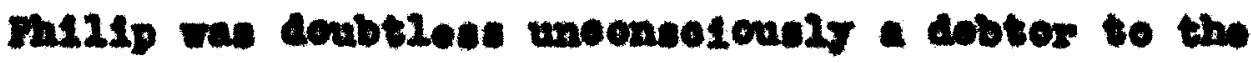
ztalien wator.

II. Lntoreat in polities and his Protontont religtes on the othor how, are the characterLetles upon which roots his ahiof olain to be called

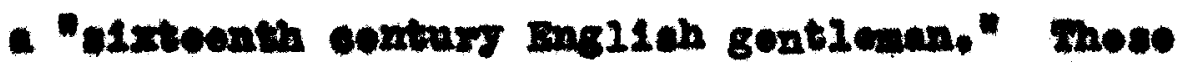
chernotoxietice were but proakgers of the intervets of that now ontorpelaling ingland whieh was to beceno a worla-power as a ropult of the colonising era.

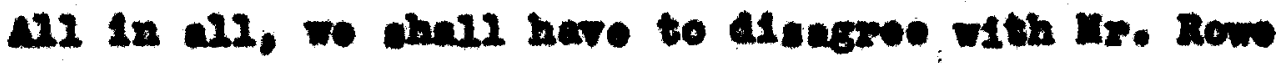

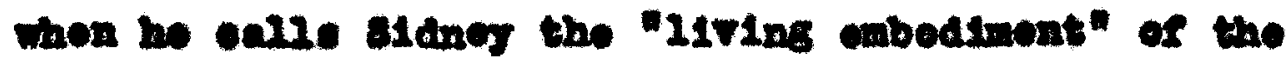




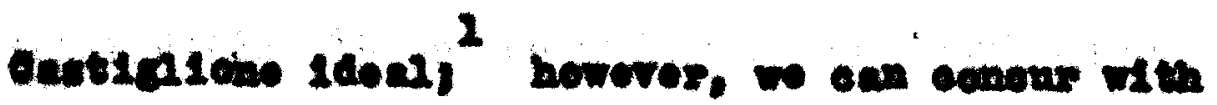

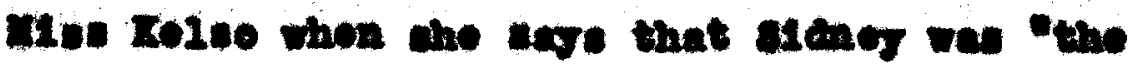

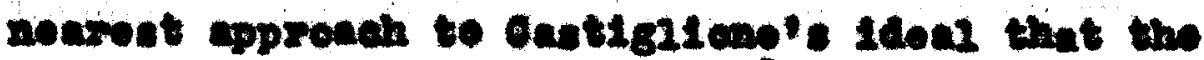

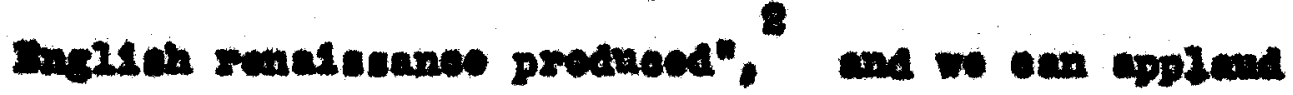

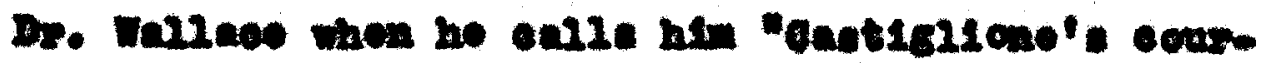
Blor rolnongated in an Inglich gentienanj and

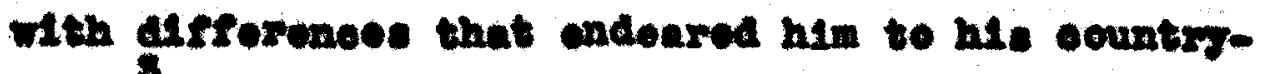

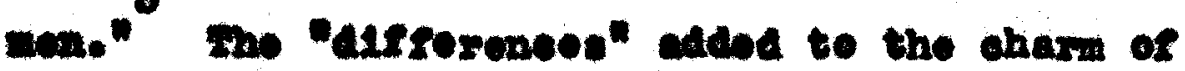
the man's persenulity, for they wore largely of the wodioral world. That ing "onsld" of his, the

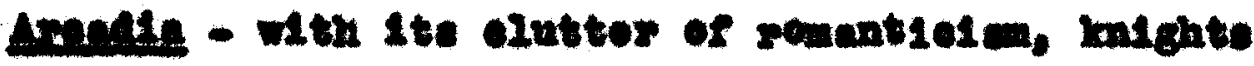

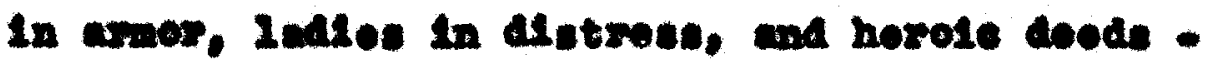
14 217ing wtwose of the kind of fanoles. "waw. naw" of then, which wose bogotsen in hil joung hod.. A broat deal of the courtier, not quite so woh ar

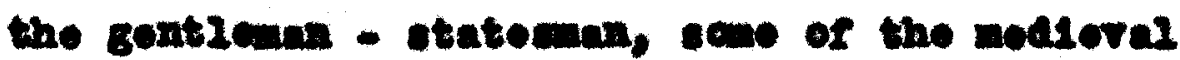

1

2. 201x, footnote, p. 230 . 8 P. 4.

"noputatien of stemp". p. 12. 


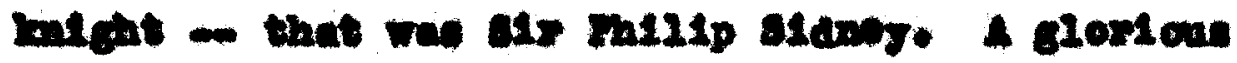

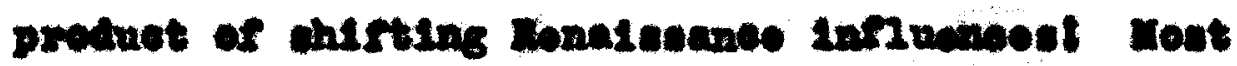

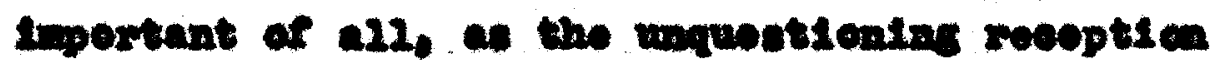
a he conmete by his coutcuponarios proved, end the wav pratsed of his frionde and onomtes allye covwoderated, bo had that woot rase tredt which whtor of both Englieh and Italian courtecy books

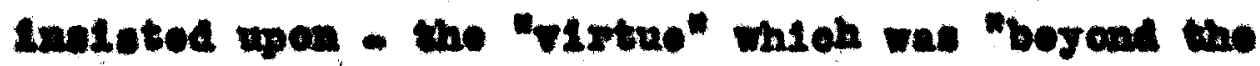
soan of rate".

It wat bo a saneg of Wr. Don Bourne's,

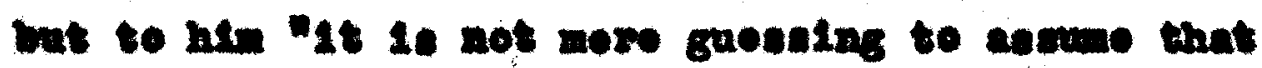

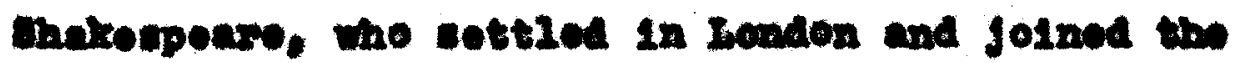
Iarl of Inlecotorle ocmpany of pleyere wh12 ald the

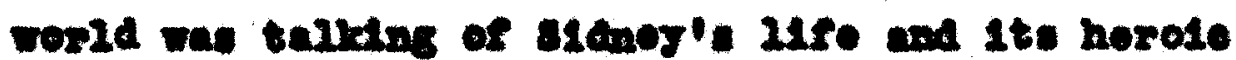
coleng, had hin in he thoughts when bo wade opholle peok of Inetot as

'Tho pourtior's, sholar's, noldser's cre. tongas, word, two oxpeotaney and rose of the faly etete.

The gias of ranton and tho mourd of rons. 
The obeorved of al1 obeorwors"

(innt, 2xx, 1, 160-108)".2

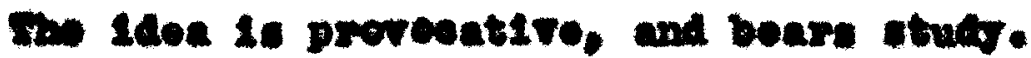

It soens fltting to ano with thone

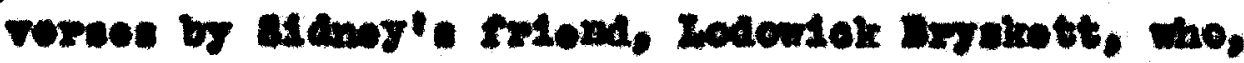

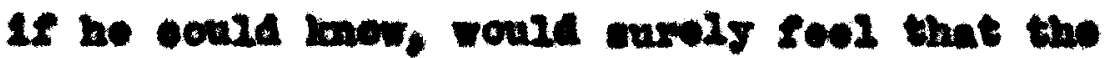

"wowthle mi111p's" fon loave nothing to bo controt.

- All halle, therefore, o worthle mi12, inoortali,

the 2lows of srengres raes. the nonour of bis neme.

wose worthse presee to atrs - Iuses not atpire.

Dint corrowini and oed thoes toares to the 10 t rall.

Iot wish thele veroes aight so rarwo and wide thy fomo

ruterd, that om 100 rage, nor. the, wight ond the inoo."

2

80. Jox Bourne. D. 861.

8

Sponesr. p. 708. 
Mblecorapto

; 


\section{Dsb1Loganing}

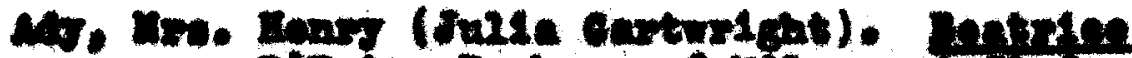

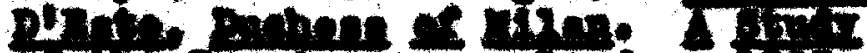

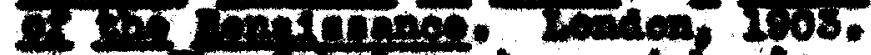

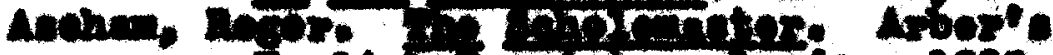

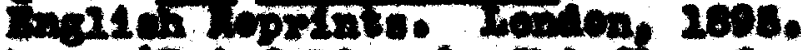

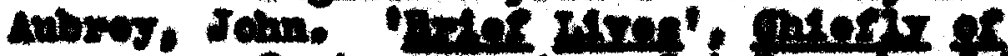

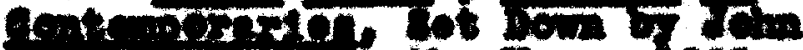

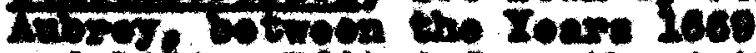
and 1860. Elted from tho sther's

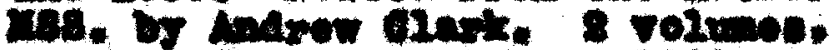

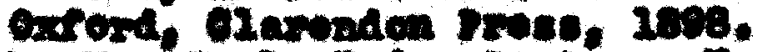

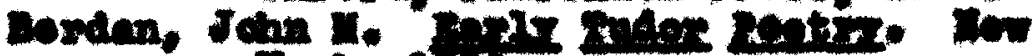
Iork, 140

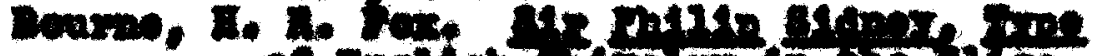

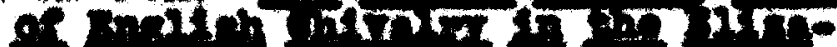

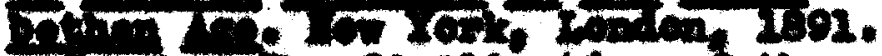

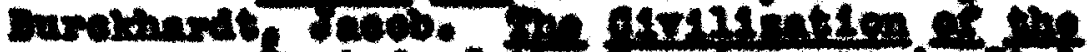

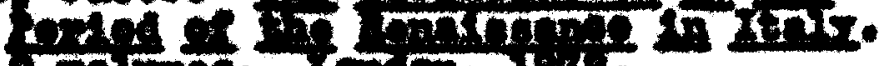

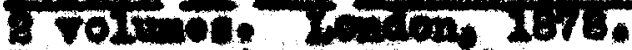

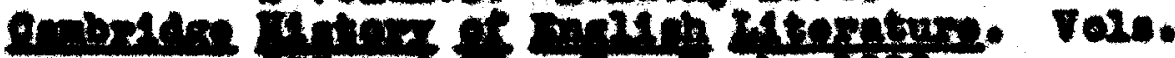

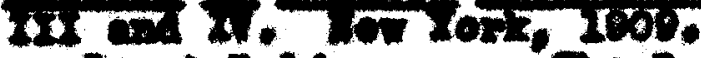

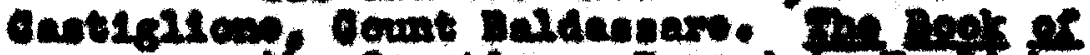

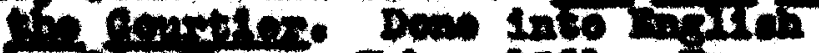

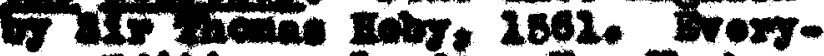
ma Irtion. Iondon, Iow Iork.

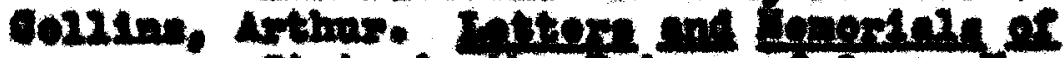

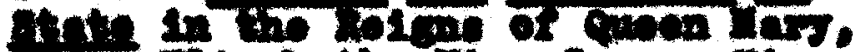

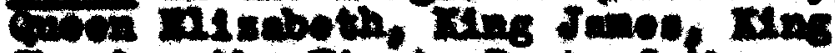

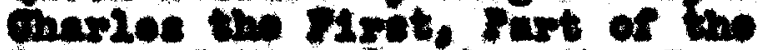

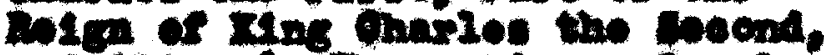
and cliverls vewpation, i volubes. ronden, 1746.

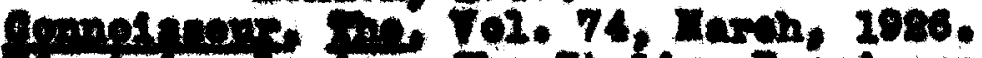

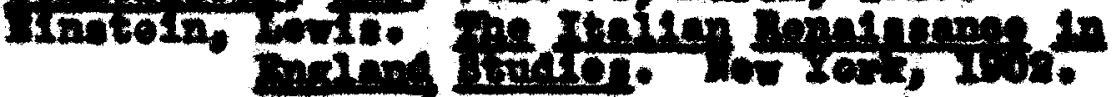


Erskine, John. The Elizabethen Lyrio. Hew York. 1016 .

Fletcher, Jefferson Butlor. The Religion or Benuty in Momen. Ter Tork, 1012.

aroville, Sir Fulre. LIre or sir Philip Sidner. Plrat Pubilened 1652 , Thth an Introduotion by Noweli smith. At the Clerendon Preas, 1807.

Quezso, K. Steeven. The civile converution. The riret throe books tringiretod by George Pettie, and the fourth by Bertholomer Young, with on Introduction by S1r Edward Sulliwen. In Two Volumes. Tudor Treneletione. Hew York, 1925.

He 11, Hubert. Soolety In the El1zebethen Age. Lond on 1886 .

Hogrefe, Pearl. "Blyot and 'The Bolro Celled Cortiglono in Ytolion." Modern Ph1 lology, XXVII, 303-300.

Ke 1s0, Ruth. The Dootrine of the Engl1sh Centieman In the SIxteenth century. Univarelty or IIInols Frose, Urbena, 1029.

Lee, Vernon. Euphorlon: Belng Studiea of the Antigu and the ledreve in the kenelagence. Boston, 2884.

Lee, SIdne Y. Elizabethan Sonnets, An EngIish corner. VoIune $I_{\text {, Westminate }}$, 1904 .

Leo, S1gney. Greet Engllabmen of the S1xteenth Century - Men York, 1904 .

Lyly, John. Euphues. The Anatomy of IIIt, Euphue ond his Englond. Edited 6y Korr 1. WIIIa Croll and Ha rry Clemona. London, 1926. 


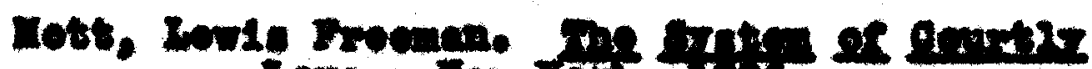

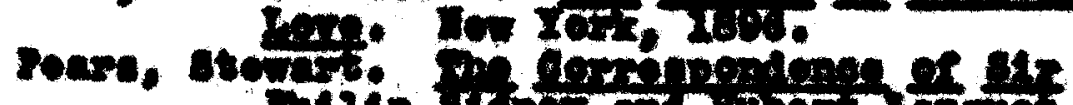

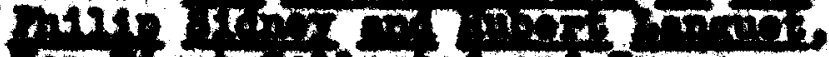

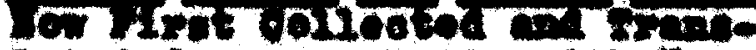
Iated frem the Latin wen Ioton ond a renats of alderes. Iondon. 1946.

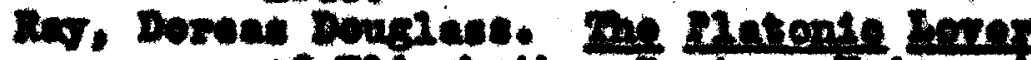

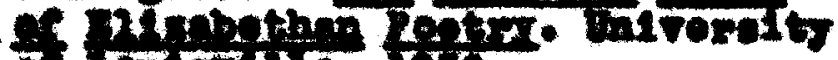

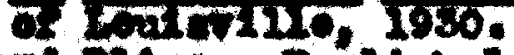

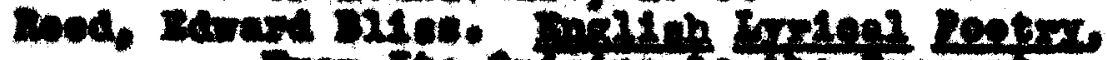

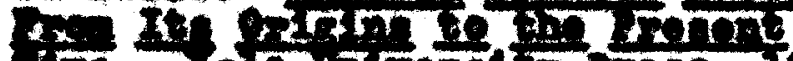

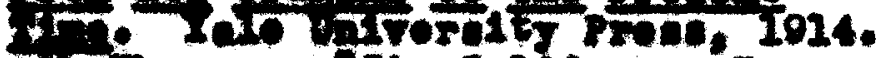

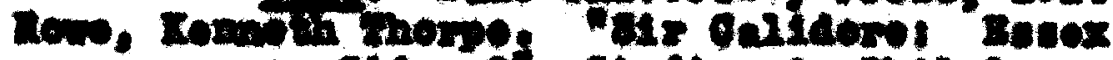

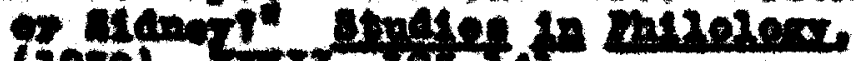

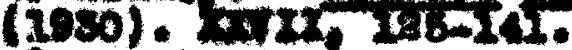

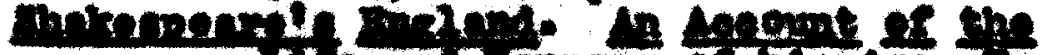

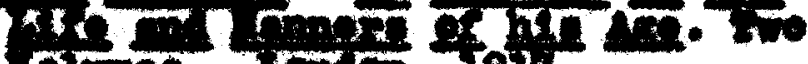
or To. Tom, IOH.

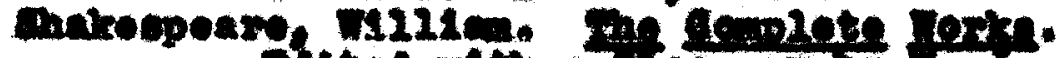

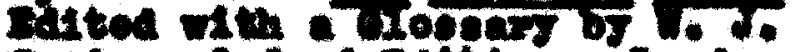

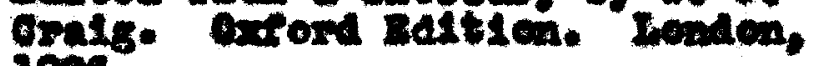
2826.

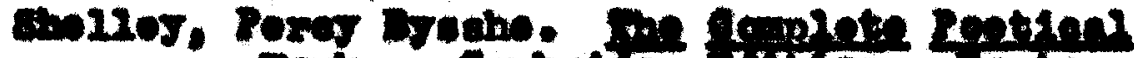
rope gebritso vation. Looton man 1002, 1901.

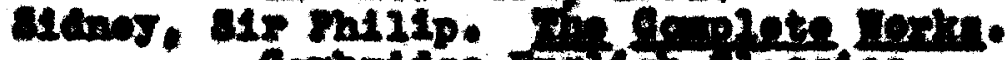
combidige topint kantos. alited to arbert roulliorist. $s$ rolwien. Sebriage Bnitrereits jroper. 2002.

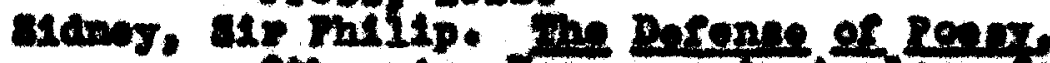

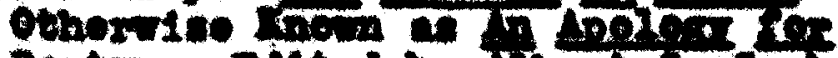

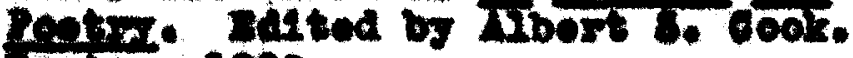
borben, 1800.

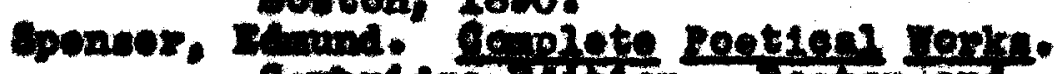
gropidge kation. Dorten ton. Now Ior. 2008 . 


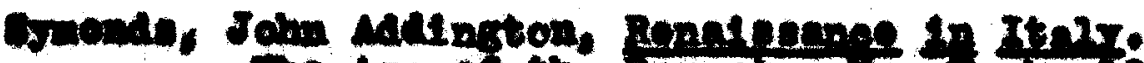

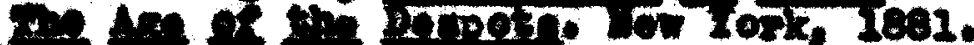

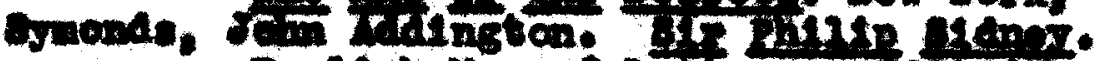

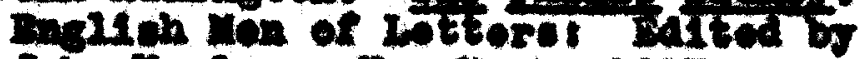

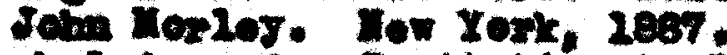

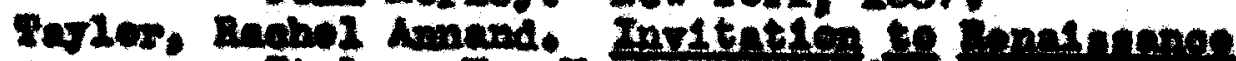

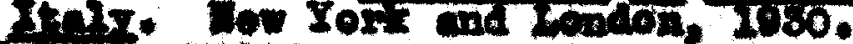

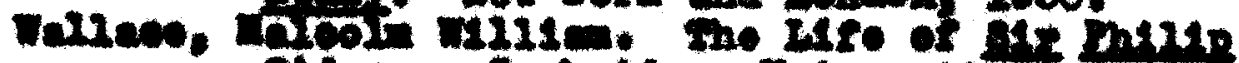

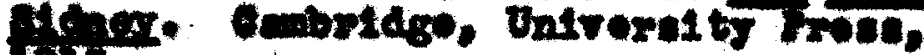
1016.

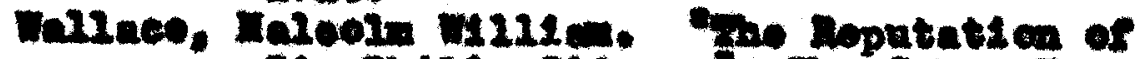

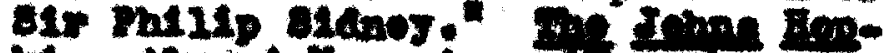

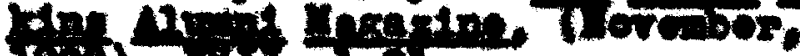

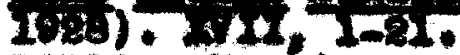

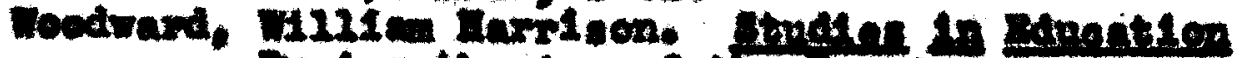

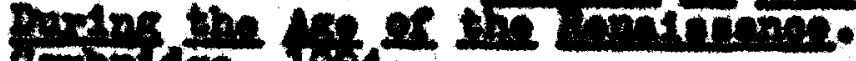
imbitos 18it.

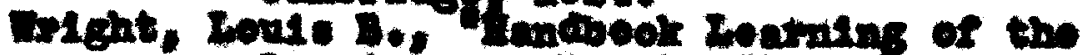

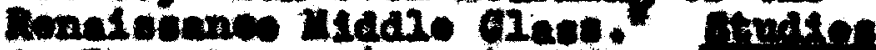

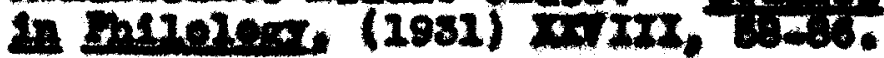

